UNIVERSIDADE DE SÃO PAULO

FACULDADE DE FILOSOFIA, LETRAS E CIÊNCIAS HUMANAS

DEPARTAMENTO DE LETRAS MODERNAS

PROGRAMA DE PÓS-GRADUAÇÃO EM ESTUDOS LINGUÍSTICOS E LITERÁRIOS

EM INGLÊS

MARIA DOLORES WIRTS BRAGA

O discurso sobre o livro didático de inglês: a construção da verdade na sociedade de controle

Versão corrigida

SÃO PAULO

2014 
O discurso sobre o livro didático de inglês: a construção da verdade na sociedade de controle

Versão corrigida

De acordo:

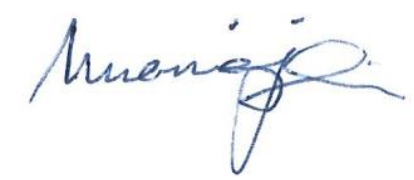

Orientadora: $\operatorname{Prof}^{\mathrm{a} .} \operatorname{Dr}^{\mathrm{a} .}$ Marisa Grigoletto

Tese apresentada ao Departamento de Letras Modernas da Faculdade de Filosofia, Letras e Ciências Humanas da Universidade de São Paulo para a obtenção do título de doutora em Letras.

Área de concentração: Estudos Linguísticos e Literários em Inglês

Orientadora: Prof ${ }^{\text {a. }}$ Dr $^{\text {a. }}$ Marisa Grigoletto 
Nome: BRAGA, Maria Dolores Wirts

Título: O discurso sobre o livro didático de inglês: a construção da verdade na sociedade de controle

Tese apresentada ao Departamento de Letras Modernas da Faculdade de Filosofia, Letras e Ciências Humanas da Universidade de São Paulo para a obtenção do título de doutora em Letras.

Aprovada em: 25 de abril de 2014

\section{Banca Examinadora}

Prof $^{\text {a. }}$ Dr $^{\text {a. }}$ Marisa Grigoletto (orientadora) - Universidade de São Paulo

Prof $^{\text {a. }}$ Dr $^{\text {a. }}$ Anna Maria Grammatico Carmagnani - Universidade de São Paulo

Prof $^{\text {a. }}$ Dr $^{\text {a. }}$ Maralice de Souza Neves - Universidade Federal de Minas Gerais

$\operatorname{Prof}^{\text {a. }}$ Dr $^{\text {a. }}$ Deusa Maria de Souza Pinheiro Passos - Universidade de São Paulo

Prof. Dr. Ernesto Sérgio Bertoldo - Universidade Federal de Uberlândia 
Ao Niuton, meu esposo, à Stephanie, minha filha, e ao Mathias, meu filho, pela paciência e incentivo.

À Nena, minha mãe, e ao Seppe, meu pai, pelos valores e exemplos de vida.

À Maxine, minha mom, e ao Howard, meu $d a d$, pela língua inglesa. 


\section{AGRADECIMENTOS}

A Deus, a Jesus e ao plano espiritual, pela vida e pelas superações.

À Dna. Nair e à Dna. Leida, pelo significado da palavra professora.

À Professora Marisa Grigoletto, pela Análise do Discurso, pelo apoio e pela presença sempre constantes, pelas contribuições diretas e indiretas a esta pesquisa e pela orientação precisa, sábia e estimulante nesses dez anos de convivência acadêmica.

À Professora Anna Maria G. Carmagnani, pela dedicação nas leituras dos meus textos e pelas contribuições valiosas tanto no mestrado como agora no doutorado.

À Professora Maralice de Souza Neves, pelo carinho e generosidade de compartilhar textos e informações, por indicar respondentes ao meu questionário de pesquisa, pela leitura cuidadosa do meu texto e pelas contribuições importantes.

Aos colegas do LEDI, em especial, à Laura e à Inês, pela amizade, pelas trocas e pelo estímulo durante a caminhada.

Aos professores que responderam aos questionários desta pesquisa.

À Professora Elisa Alencar, pela distribuição, coleta e envio dos questionários.

À CAPES, pelo auxílio financeiro no início desta pesquisa.

À FAPESP, pelo auxílio financeiro fundamental para a realização desta tese. 
Uma sociedade "sem relações de poder" só pode ser uma abstração. O que, diga-se de passagem, torna ainda mais necessária, do ponto de vista político, a análise daquilo que elas são numa dada sociedade, de sua formação histórica, daquilo que as torna sólidas ou frágeis, das condições que são necessárias para transformar umas, abolir as outras. Pois, dizer que não pode existir sociedade sem relação de poder não quer dizer nem que aquelas que são dadas são necessárias, nem que de qualquer modo o "poder" constitua, no centro das sociedades, uma fatalidade incontornável; mas que a análise, a elaboração, a retomada da questão das relações de poder, e do "agonismo" entre relações de poder e intransitividade da liberdade, é uma tarefa política incessante; e que é exatamente esta a tarefa política inerente a toda existência social.

Michel Foucault. Michel Foucault, uma trajetória filosófica para além do estruturalismo e da hermenêutica. 


\section{RESUMO}

\section{BRAGA, M. D. W. O discurso sobre o livro didático de inglês: a construção da verdade}

na sociedade de controle. 2014. 246 f. Tese (Doutorado) - Faculdade de Filosofia, Letras e

Ciências Humanas, Universidade de São Paulo, São Paulo, 2014.

Nossa proposta de investigar o discurso sobre o livro didático de inglês toca inevitavelmente na questão do discurso de verdade do livro didático. Direcionada pela hipótese de que o poder de discurso de verdade do livro didático de inglês (LDI) é construído pelos dizeres acerca do LDI, nossa pesquisa dedica-se a estudar o funcionamento desse que chamamos de discurso sobre o LDI e os efeitos de sentido que ele produz. Mais especificamente, estudamos os dizeres sobre o LDI adotado na escola pública brasileira a partir do Programa Nacional do Livro Didático, PNLD 2011. Apesar de o LDI já ter sido adotado localmente na rede pública por algumas escolas ou alguns professores, é através do PNLD 2011 que o governo federal, pela primeira vez, propõe títulos a serem adotados em âmbito nacional, patrocinando o custo desses materiais consumíveis, para o ensino de língua estrangeira (espanhol e inglês). Para esta investigação, apoiamos nossas observações nos conceitos pertinentes à linha pecheutiana de Análise do Discurso. Esses conceitos fundamentam a nossa análise dos dizeres do corpus de pesquisa, formado por três segmentos. O segmento oficial compreende os principais documentos referentes ao PNDL 2011. O segmento midiático foi composto por textos disponibilizados na internet, publicados por agências de notícias governamentais e não governamentais e por sites de escolas e associações. $\mathrm{O}$ segmento profissional contou com as respostas de professores de inglês do $6^{\circ}$ ao $9^{\circ}$ ano da rede pública de ensino. Essas respostas foram coletadas em dois momentos através de questionários de pesquisa. No primeiro momento, as coleções que compuseram o PNLD 2011 ainda não eram conhecidas pelos professores respondentes. No segundo momento, os professores que responderam ao segundo questionário já utilizavam as coleções de inglês do PNLD 2011. A análise do discurso sobre o livro didático de inglês nos possibilitou a percepção de efeitos que apontam ao funcionamento do LDI como verdade por ser representado como tal pelo discurso que fala sobre ele. Através da análise, observamos também efeitos característicos do funcionamento das sociedades de controle, como prevista por Michel Foucault ([1979] 2004) e discutida por Gilles Deleuze ([1990] 1992). No eixo do interdiscurso, percebemos nos enunciados os princípios moduladores, garantindo o adiamento do fim, demandando atualizações contínuas, motivando o indivíduo e assegurando o controle. No eixo do intradiscurso, a materialidade linguística mostrou-se frequentemente marcada pela modalização dos dizeres, suavizando-os e suscitando múltiplas possibilidades. Os efeitos percebidos parecem funcionar como os princípios moduladores, formulados por Deleuze ([1990] 1992), que marcam a relação saberpoder funcionando já nos moldes da sociedade de controle.

Palavras-chave: discurso sobre o livro didático de inglês; Análise do Discurso; sociedade de controle; princípios moduladores; modalização. 


\begin{abstract}
BRAGA, M. D. W. The discourse about the English textbook: the construction of truth in the society of control. 2014. 246 p. Thesis $(\mathrm{PhD})$ - Faculdade de Filosofia, Letras e Ciências Humanas, Universidade de São Paulo, São Paulo, 2014.

Our aim to investigate the discourse about the English textbook inevitably touches on the issue of the textbook as a discourse of truth. Driven by the hypothesis that the power of discourse of truth, often attributed to the textbook, is built by the discourse which speaks about the textbook, our research aims to study the functioning mode and the effects of that discourse which we name discourse about the English textbook. Although English textbooks have been adopted in some courses by some public school teachers here and there, this is the first time that the Brazilian federal government has proposed the nation-wide adoption of foreign language textbooks (English and/or Spanish) through the National Textbook Program for the year of 2011 (PNLD 2011) by selecting titles for teachers to choose from and by bearing all the expenses involved in the process. Our research follows the conceptualization of Discourse Analysis as established by Michel Pêcheux. Those concepts guide the analysis of the excerpts in our research corpus, which is composed of three segments. The official discourse segment contains excerpts from the most relevant documents issued by the government on the PNLD 2011. The media discourse segment comprises online news and articles issued by governmental as well as non-governmental news agencies and by schools and associations sites. The professional discourse segment holds the answers provided by public school teachers of English $\left(6^{\text {th }}\right.$ to $9^{\text {th }}$ grades $)$ to two questionnaires on the adoption of the English textbook. Their answers were collected in two distinct moments. The first questionnaire was answered by the teachers before textbook collections were pre-selected to integrate the PNLD 2011. The second questionnaire was answered by teachers who already used the PNLD 2011 textbooks. The analysis of the discourse about the English textbook led us to the perception of effects which confirm the functioning of the English textbook as a discourse of truth since it is represented as such by the discourse about it. Through discourse analysis, we have also observed effects which are typical of the functioning mode of societies of control, as briefly defined by Michel Foucault ([1979] 2004) and further contended by Gilles Deleuze ([1990] 1992). In the interdiscourse axis, modulating principles were observed in enouncements, as they ensure limitless postponements, demand continuous updating, motivate the individual and ensure control. In the intradiscourse axis, the linguistic materiality often presented excerpts marked by modalization, which softens the remarks and gives rise to multiple possibilities. The effects observed seem to work as modulating principles, as formulated by Deleuze ([1990] 1992), which confirms that the relationship between power and knowledge is already functioning in the modes of societies of control.
\end{abstract}

Key words: discourse about the English textbook; Discourse Analysis; society of control; modulating principles; modalization. 


\section{SUMÁRIO}

INTRODUÇÃO

PARTE 1 - O LIVRO DIDÁTICO DE INGLÊS

CAPÍTULO 1 - O CONTEXTO HISTÓRICO 31

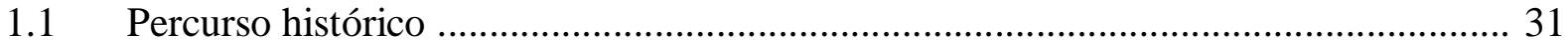

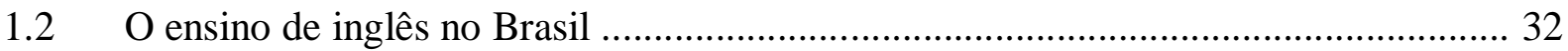

1.3 O livro didático de inglês no Brasil ........................................................................ 43

1.4 Estudos do discurso sobre o livro didático de inglês no Brasil ................................... 51

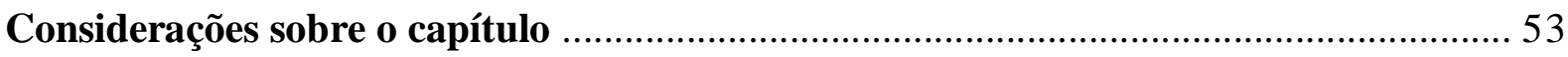

\section{CAPÍTULO 2 - VERDADE E LIVRO DIDÁTICO: um instrumento oficial e}

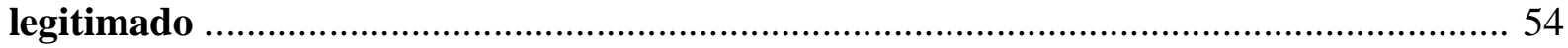

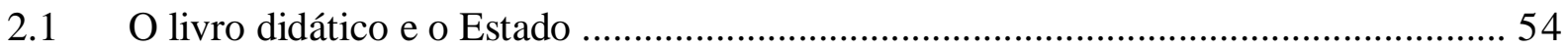

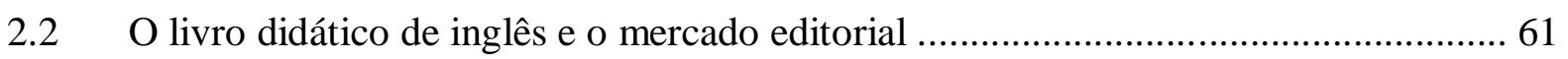

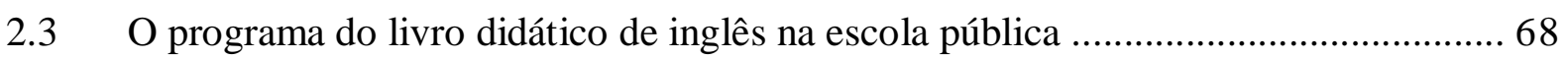

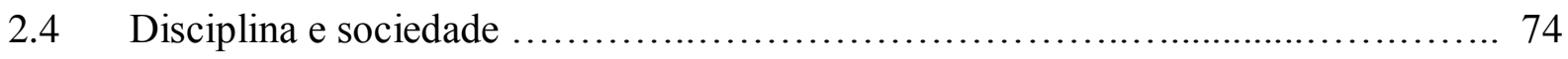

2.5 O poder de discurso de verdade do livro didático ...................................................... 77

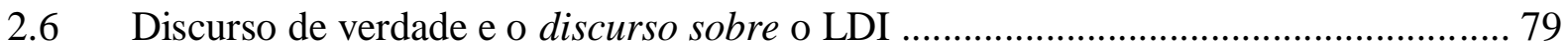

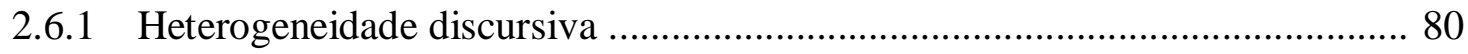

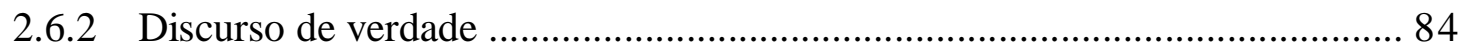

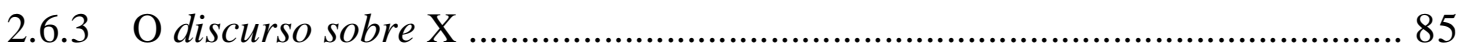

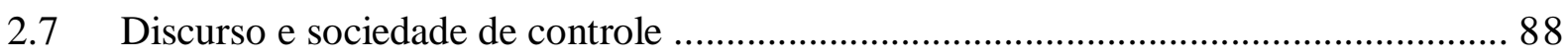

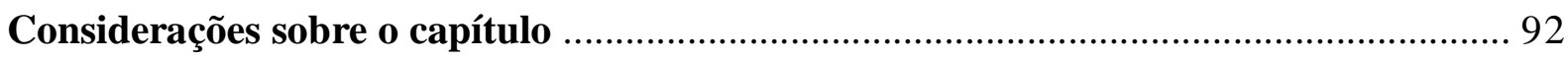

PARTE 2 - ANÁLISE DE DIZERES DO DISCURSO SOBRE O LIVRO DIDÁTICO

DE INGLÊE

CAPÍTULO 3 - AS CATEGORIAS DE ANÁLISE ...................................................... 97

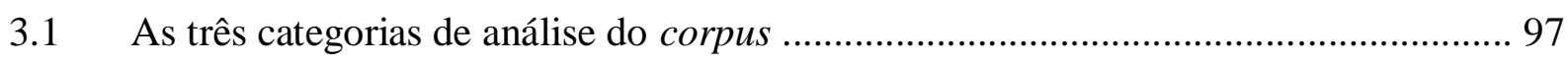

3.2 O professor como uma pessoa que age .................................................................. 98

3.3 A possibilidade de se abrir "todo um campo de respostas, reações, efeitos e 
invenções". 99

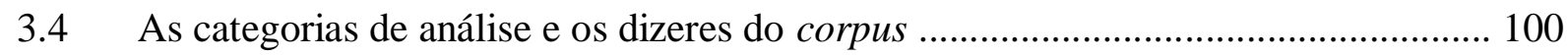

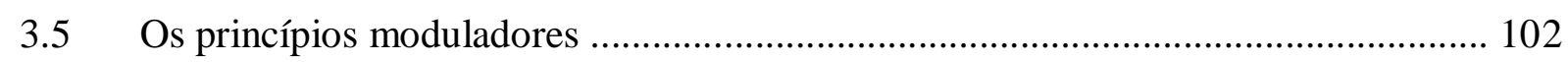

CAPÍTULO 4 - PODER: O INVESTIMENTO DO DISCURSO SOBRE O LDI ....... 103

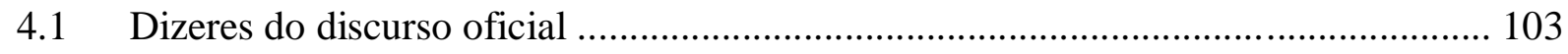

4.2 Dizeres do discurso profissional .................................................... 106

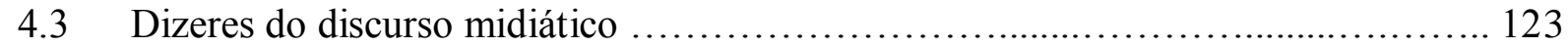

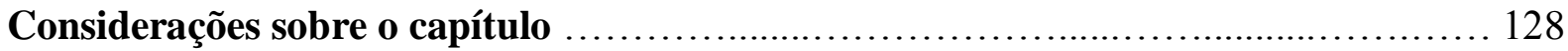

CAPÍtulo 5 - VERdAdE: A CONSTRUÇÃO DISCURSIVA DO SABER NO

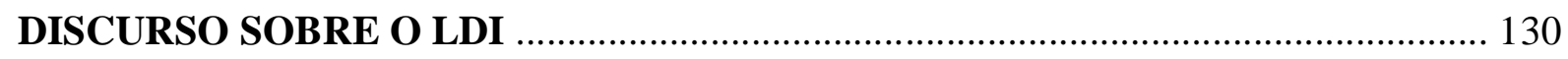

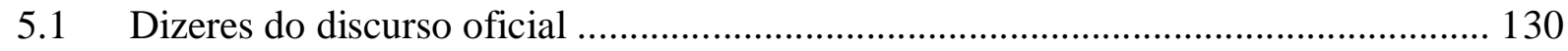

5.1.1 A escolha nos dizeres do Edital de Convocação ............................................ 132

5.1.2 A escolha nos dizeres do Guia de Livros Didáticos .................................... 135

5.1.2.1 A Ficha de Avaliação .................................................................... 137

5.1.2.2 O Quadro Comparativo das Coleções de L.E.M. ........................................ 140

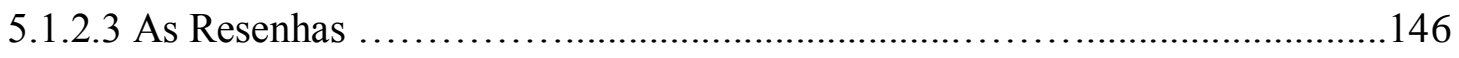

5.1.3 A escolha na sociedade de controle ……...................................................... 151

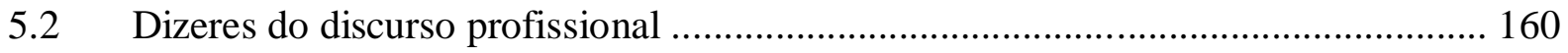

5.3 Dizeres do discurso midiático …............................................................. 170

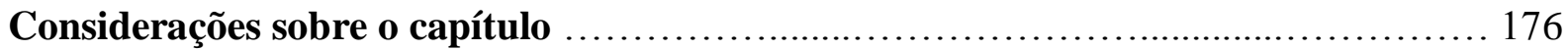

CAPÍTULO 6 - A ARTICULAÇÃO DA RELAÇÃO SABER-PODER ..................... 179

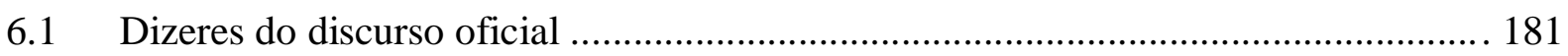

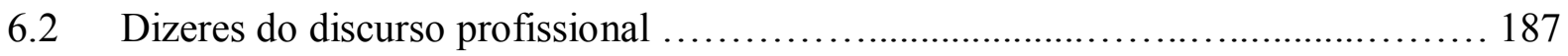

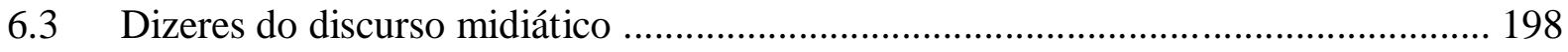

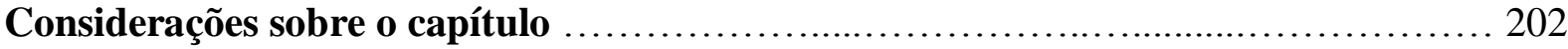

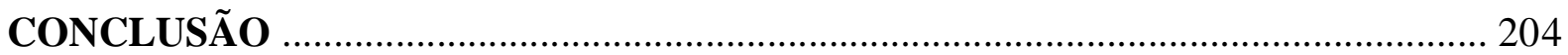

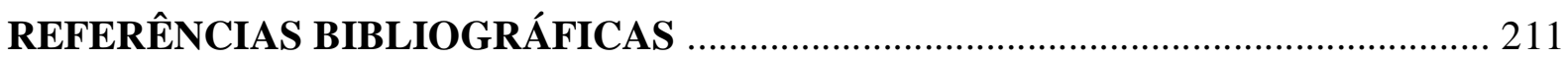

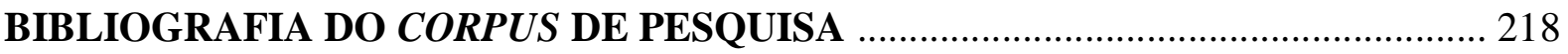


APÊNDICE - LEVANTAMENTO SOBRE TRABALHOS NA ÁREA - CONJUNTO DA

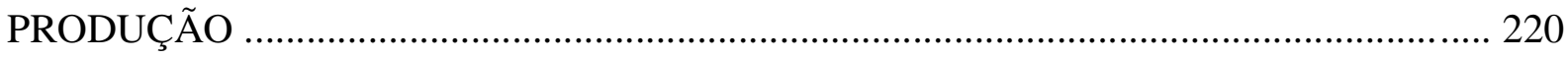

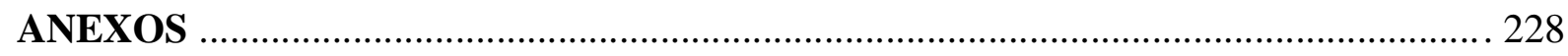




\section{INTRODUÇÃO}

A produção da verdade, segundo Michel Foucault ${ }^{1}$, é a incumbência do poder. Foucault nos fala da dupla exigência do poder em que devemos produzir a verdade por estarmos, ao mesmo tempo, submetidos ao poder e para exercê-lo. Ou seja, o poder nos obriga a produzir a verdade, pois é somente pela produção da verdade que conseguimos exercê-lo. Por isso, de acordo com o filósofo, não há exercício de poder sem a produção de discursos de verdade. Entendemos que a verdade é definida por ele como um saber discursivo, ou "um conjunto de procedimentos regulados para a produção, a lei, a repartição, a circulação e o funcionamento dos enunciados" (FOUCAULT, M., [1979] 2004, p. 14).

Segundo o autor, nessa relação circular entre o poder e o saber, cada sociedade constrói seu regime de verdade, acolhendo os tipos de discurso que devem funcionar como verdadeiros, estabelecendo os modos de distinção entre o falso e o verdadeiro, valorizando as estratégias que levam à verdade e, ainda, especificando o estatuto dos encarregados de julgarem o que deve funcionar como verdade ${ }^{2}$. É precisamente nesse ponto de observação sobre os modos de construção do regime de verdade em nossa sociedade que desejamos inserir nossa pesquisa.

Observamos que o livro didático de língua inglesa (doravante, LDI) é acolhido por nossa sociedade como um discurso de verdade ${ }^{3}$. Partindo dessa observação, já nos encontramos diante de alguns questionamentos. $\mathrm{O}$ estranhamento primário com o qual nos deparamos, e que nos direcionou a questões mais pertinentes à pesquisa científica, foi exatamente a observação de que o LDI, isto é, o discurso do LDI é percebido como sendo uma "verdade"4 inquestionável pelos professores que o utilizam, suplantando até mesmo os saberes construídos por esses professores em seus percursos profissionais. Pessoalmente, a aceitação do LDI como verdade sempre nos incomodou, tanto quando ocupamos a posição de professora de inglês como quando exercemos o cargo de coordenadora de um grupo de professores de inglês em uma escola de ensino regular da rede privada de ensino. Não foram poucos os momentos em que presenciamos professores procurando compreender as "verdades" do LDI para que pudessem defendê-las, em detrimento de seus próprios saberes, perante seus alunos. Para muitos desses professores, era difícil, no trabalho com o LDI,

\footnotetext{
${ }^{1}$ FOUCAULT, M., [1979] 2004.

${ }^{2}$ Idem.

${ }^{3}$ Cf. CORACINI, M. J., (org.), 1999.

${ }^{4}$ Usamos a palavra entre aspas para marcar nosso distanciamento da concepção de verdade como realidade empírica, pois acreditamos que a verdade seja uma construção discursiva, portanto, dependente das condições de formação e produção do discurso, das formações discursivas e ideológicas envolvidas.
} 
questionar as chaves de respostas de exercícios que apresentassem soluções equivocadas, contra-argumentar as informações culturais generalizantes apresentadas em alguns textos, repensar as sugestões de práticas didáticas e propor outros encaminhamentos diferentes daqueles apresentados pelo discurso do LDI. Desse modo, o saber e a verdade do LDI adquiria, para aqueles professores, um status de verdade absoluta. É essa rigidez que o discurso do LDI parece impor às ações dos professores que nos motiva a busca por entender seu funcionamento como um discurso de verdade.

Seguindo o pensar de Foucault, ao considerarmos que o LDI seja um tipo de discurso de verdade produzido por um poder, não podemos crer que o LDI possa por si estabelecer-se como discurso de verdade, visto que deva ser produzido por um poder. Do mesmo modo, não podemos pensar que o LDI construa seu próprio poder. Ou seja, o discurso do LDI, no desenrolar das formulações e atividades, não constrói sozinho seu próprio poder, nem seus efeitos de verdade. Acreditamos que o poder e a verdade do LDI sejam, em boa parte, construídos nos discursos sobre o LDI. Em outros termos, acreditamos que os aspectos que fazem o LDI funcionar como um discurso de verdade, como seus efeitos de transparência e seu caráter homogeneizante ${ }^{5}$, cuja instauração é muitas vezes atribuída apenas à autoria ${ }^{6}$, corroboram um processo instaurado, mobilizado e mantido pelo discurso sobre o LDI. Assim, o discurso sobre o LDI será nosso objeto de pesquisa.

Nossa hipótese, portanto, é composta pelo argumento de que não é exatamente o LDI por si só, mas o discurso sobre o LDI que exerce o poder mobilizador de seu efeito de verdade. Ainda compondo nossa hipótese, acreditamos que o poder do discurso sobre o LDI funciona de um modo específico, com algumas características do poder disciplinar detalhado por Michel Foucault, mas com especificidades que o delineiam como um novo tipo de poder ${ }^{7}$. Há, a partir daí, outra inquietação considerada pela pesquisa: nossa sociedade não pode mais ser caracterizada nos moldes da sociedade disciplinar que Foucault analisou. Para podermos formular argumentos mais precisos, devemos, através dos estudos das representações no discurso, investigar as características que delineiam a sociedade em que vivemos e como ela constrói seu regime de verdade.

A partir dessas observações, e apoiando-nos nas proposições foucaultianas sobre os regimes de verdade, lembradas em nosso segundo parágrafo, formulamos nossas perguntas de pesquisa.

\footnotetext{
${ }^{5}$ Cf. GRIGOLETTO, M., 1999, p. 68.

${ }^{6}$ Ou à função-autor; cf. FOUCAULT, M., [1969] 2002.

${ }^{7}$ Referimo-nos ao poder das sociedades de controle que será detalhado antes de finalizarmos esta introdução e também no item 2.7 deste estudo.
} 
- Que representações são construídas em torno do LDI, fazendo com que ele funcione socialmente como uma verdade?

- Que representações são construídas no/pelo discurso sobre o LDI em relação à língua inglesa, ao ensino de inglês como língua estrangeira, ao aluno e ao professor?

Acreditamos que as respostas a esses questionamentos nos auxiliam a investigar nossa hipótese de que o discurso sobre o LDI constrói representações do LDI que, funcionando como saberes, isto é, como verdade, lhe outorgam poder de discurso de verdade. Consideramos, assim, o LDI como um lugar de encontro de discursos que refletem os modos de circulação do poder em nossa sociedade. Questionamos, ainda, os modos de circulação desse poder em nossa sociedade que, argumentaremos adiante, pode ser já considerada como funcionando como uma sociedade de controle. Nossa hipótese, então, compreende os seguintes aspectos:

- A representação do livro didático para o ensino de inglês como discurso de verdade é construída no discurso sobre o LDI. Apesar de não conseguir se manter homogênea, essa construção investe poder no LDI, para que ele funcione como um discurso de verdade.

- O discurso sobre o LDI permite a percepção de efeitos e funcionamentos que podem ser considerados como característicos da sociedade de $\operatorname{controle}^{8}$ e não mais predominantemente da sociedade disciplinar.

A escolha do tema de nossa pesquisa é justificada pela necessidade de entendermos o funcionamento do livro didático como um saber que se sobrepõe ao saber do professor, atingindo muitas vezes o status de verdade inquestionável. Nosso olhar se deterá sobre o livro didático de inglês primordialmente. Esse recorte é motivado pelo fato de ter sido o LDI que se apresentava como a verdade que os professores em nosso entorno se obrigavam a respeitar e, também, por ser o LDI um dos representantes das duas únicas línguas estrangeiras (inglês e espanhol, em detrimento de outras línguas) a fazerem parte da primeira adoção nacional de livros didáticos de línguas estrangeiras na escola pública brasileira. Desejamos, assim, estudar o funcionamento do discurso sobre o LDI, discurso este que faz, como acreditamos, do LDI

\footnotetext{
${ }^{8}$ Ver item 2.7.
} 
um lugar de verdade, para que possamos entender também como se processa a relação saberpoder em nossa sociedade atualmente e suas consequências para o processo de ensinoaprendizagem da língua inglesa em nosso país.

Neste momento, especificamente, o LDI marca sua presença na história do ensino de inglês como língua estrangeira no território brasileiro. Isso porque, a partir de 2011, para os últimos anos do Ensino Fundamental, e de 2012, para o Ensino Médio ${ }^{9}$, através de uma iniciativa do governo federal, o LDI passa a compor a lista de materiais adotados pela escola pública em todo o território nacional. Apesar de o LDI já ter sido adotado localmente na rede pública por algumas escolas ou alguns professores, esta é a primeira vez que o governo federal, através do Programa Nacional do Livro Didático (de agora em diante, PNLD), propõe títulos a serem adotados em âmbito nacional, patrocinando o programa de adoção desses materiais consumíveis para o ensino de língua estrangeira (espanhol e inglês).

Essa entrada maciça do LDI na escola pública instigou-nos a pensar sobre o papel do LDI nesse momento, após mais de duzentos anos de ensino de inglês como língua estrangeira no Brasil. Longe de seu domínio costumeiro (a rede privada e os institutos de idiomas), o LDI pode estar representando uma grande mudança ou apenas garantindo velhos valores. Acreditamos que a análise do discurso sobre o LDI nos ajuda a entender o que se deseja do LDI nesse momento para nossa sociedade, oferecendo, então, elementos para percebermos os rumos traçados para o ensino de língua inglesa em nosso país. Os pressupostos e as expectativas, perceptíveis na análise do discurso sobre o LDI, podem delinear novas representações de aluno, professor e língua; questões de grande importância para todos os envolvidos com o ensino e a aprendizagem de inglês como língua estrangeira.

Analisamos excertos do discurso sobre o LDI, com o objetivo mais amplo de percebermos as características dos modos de circulação do poder em nossa sociedade. Nosso objetivo específico se concentra em perceber as representações construídas no/pelo discurso sobre o LDI. A percepção desses efeitos discursivos nos auxilia a compreender e a problematizar os papéis do professor, do aluno e do livro didático de língua inglesa, assim como o ensino da língua inglesa, em nossa sociedade.

Acolhemos como espinha dorsal da pesquisa a Análise do Discurso pecheutiana, considerando, pois, o sujeito como efeito do discurso e as representações como construções que se formam em meio à história, à memória, à ideologia e à constituição do sujeito como ser

\footnotetext{
${ }^{9}$ Cf. o documento intitulado Orientações CENP para a escolha de livros didáticos do PNLD 2012 assinado por Coordenação Nacional do PNLD em São Paulo - Equipe Técnica da CENP/SEE-SP. Disponível em: <http://pnld.edunet.sp.gov.br/2012/Arquivos/Orientacoes_Geral.pdf>. Acesso em: 06 fev. 2013.
} 
na/da linguagem e que deixam suas marcas na materialidade do discurso. A Análise do Discurso pecheutiana (de agora em diante, AD) considera o discurso como estrutura e acontecimento (PÊCHEUX, M., [1983] 2002), respectivamente materialidade linguística, no nível do intradiscurso, e materialidade histórica, no interdiscurso. A materialidade linguística é já marcada pela materialidade histórica, ou atravessamentos de historicidade - memória e ideologia - no momento da enunciação.

$\mathrm{O}$ sujeito, para a $\mathrm{AD}^{10}$, se constitui no discurso no momento em que o indivíduo se identifica à ideologia e por ela é interpelado para produzir seu dizer. É a identificação do indivíduo interpelado pela ideologia que estabelece o lugar que esse sujeito ocupa e a partir do qual ele produz sentido ao dispersar-se em discurso. O sujeito, portanto, o indivíduo interpelado pela ideologia, produz e é produzido pelo discurso a partir das posições que ocupa estabelecidas por suas filiações ideológicas.

É necessário reconhecer que há falhas nesses processos de identificação e interpelação do indivíduo pela ideologia; pois, como afirma Michel Pêcheux ([1975] 2009, p. 277), "não há ritual sem falhas; enfraquecimento e brechas". Mesmo sem ser plena, a interpelação ideológica define o lugar a partir do qual o sujeito produz sentido. Isto é, a identificação a uma ideologia recorta uma formação ideológica que, por sua vez, determina uma ou mais formações discursivas, lugares de construção de sentido. É a partir da formação discursiva que o sujeito produz discurso. A formação ideológica, por sua vez, foi definida por Pêcheux como as posições ideológicas sustentadas por um sujeito e formação discursiva como o dizível da formação ideológica. Disse Pêcheux ([1975] 2009, p. 147) ${ }^{11}$ :

Chamaremos, então, formação discursiva aquilo que, numa formação ideológica dada, isto é, a partir de uma posição dada numa conjuntura dada, determinada pelo estado da luta de classes, determina o que pode e deve ser dito $[\ldots]$.

O atravessamento do inconsciente é responsável pelo descentramento e pela incompletude do sujeito, que não controla os efeitos de seu dizer. Em outros termos, embora o sujeito se veja como evidência (sou eu quem falo), e tenha o sentido de seu dizer também como evidência (é isso que falo), sua dupla fragmentação (pela ideologia e pelo inconsciente)

\footnotetext{
${ }^{10}$ Cf. PÊCHEUX, M. [1975] 2009; PÊCHEUX, M., [1983] 2002; ORLANDI, E. 1999.

${ }^{11}$ Em todas as citações de autores e excertos do discurso analisado, as aspas e os grifos (negritos e itálicos) são dos textos originais. Por isso, a partir daqui, não mais informaremos sobre a autoria desses grifos. Nossos grifos serão sempre sublinhados e não negritos ou itálicos. Informaremos sobre os termos sublinhados por outros, isto é, pelos autores dos textos originais, localmente.
} 
marca seu discurso com a falta e a falha. Originadas mesmo na ausência de identificação plena do sujeito à ideologia e na impossibilidade de controle daquilo que do inconsciente marca o dizer, aquilo que falta e falha "não pára de voltar no sujeito e no sentido que nele pretende se instalar" (PÊCHEUX, [1975] 2009, p. 276). A interpelação ideológica e o atravessamento do inconsciente contribuem à heterogeneidade que marca o sujeito, o sentido e, portanto, o discurso.

É sob essa concepção pecheutiana de discurso como dispersão do sujeito que entendemos como as representações são construídas. Ou seja, essas construções são compostas no discurso a partir das filiações ideológicas do sujeito atravessado também pelo inconsciente; portanto, não são fixas, homogêneas nem completas.

Consideramos importante, para o desenvolvimento deste trabalho, pensarmos na duração das representações. Não nos referimos exatamente à duração temporal ou cronológica dessas construções, mas nas sobreposições discursivas que vêm de algum modo alterá-las, transformá-las e/ou suplantá-las. Em termos pecheutianos, referimo-nos à permanência, ou circulação, de discursos em relação a outros, considerando o processo discursivo - "sistema de relações de substituição, paráfrases, sinonímias etc., que funcionam entre elementos linguísticos" (PÊCHEUX, M., [1975] 2009, p. 148) - até que outro discurso, com outras construções, se instaure.

Outro aspecto que nos parece imprescindível à pesquisa é o detalhamento da conceitualização foucaultiana, mas principalmente pela abordagem deleuziana, sobre a sociedade de controle. Gilles Deleuze ([1990] 2008) admite que já vivemos nessa sociedade que Foucault reconheceu ${ }^{12}$ ser a sucessora da sociedade disciplinar. Segundo Michel Foucault, a sociedade disciplinar caracteriza-se por seus métodos que controlam minuciosamente as operações do corpo, obrigando-o à sujeição numa relação entre a docilidade e a utilidade; isto é, quanto mais dócil, mais útil. Disse Foucault ([1975] 2004, p. 119):

O momento histórico das disciplinas é o momento em que nasce uma arte do corpo humano, que visa não unicamente o aumento de suas habilidades, nem tampouco aprofundar sua sujeição, mas a formação de uma relação que no mesmo mecanismo o torna tanto mais obediente quanto é mais útil, e inversamente.

Na sociedade disciplinar, esses métodos de controle do corpo são exercitados de tal forma que são internalizados e repetidos eficientemente, inculcando no indivíduo toda a

${ }^{12}$ Cf. DELEUZE, G., [1990] 2008; cf. FOUCAULT, M., [1979] 2004. 
sistemática disciplinar. Organizando o tempo e o espaço, classificando os corpos, as habilidades, as doenças etc., a sociedade disciplinar cultuava o detalhamento, a minuciosidade. Exercia-se o poder na microfísica de suas relações, possibilitando o controle minucioso e a intervenção pontual. Em Vigiar e Punir, Foucault ([1975] 2004, p. 127) observa:

Ela [a tática disciplinar] permite ao mesmo tempo a caracterização do indivíduo como indivíduo, e a colocação em ordem de uma multiplicidade dada. Ela é a condição primeira para o controle e o uso de um conjunto de elementos distintos: a base para uma microfísica de um poder que poderíamos chamar 'celular'.

Gilles Deleuze considera como uma das principais ideias da obra Vigiar e Punir, de Foucault, a definição das sociedades modernas como sociedades disciplinares e afirma que "a disciplina não pode ser identificada com uma instituição nem com um aparelho, exatamente porque ela é um tipo de poder" (DELEUZE, G., [1986] 2005). Vemos que alguns dos principais aspectos que caracterizam os meios de funcionamento do poder na sociedade disciplinar, como a organização do tempo e do espaço e o controle do corpo, já não são tão eficazes no mundo atual ou não funcionam tão bem. Com o advento das novas tecnologias de informação e comunicação (NTICs), que vêm se desenvolvendo gradativa e irrevogavelmente desde meados da década de setenta, as noções de tempo, espaço e até mesmo a noção de corpo, com os avatares, os cibercorpos digitais, têm tomado outros contornos: menos visíveis, menos concretos. Porém, tal fluidez não implica a falta de controle, apenas exige adaptação: um controle que seja também fluido, menos visível, mas muito mais rígido e eficaz. Tal transição nos leva à noção de sociedade de controle.

De acordo com Gilles Deleuze ([1990] 2008), Foucault ${ }^{13}$ marca o período dos séculos XVIII e XIX como tendo sido caracterizado pelo funcionamento das sociedades disciplinares. No início do século XX, as sociedades disciplinares atingem seu apogeu. Porém, ainda segundo Deleuze, após a Segunda Guerra mundial, com a crise dos meios de confinamento (prisão, caserna, fábrica, escola, hospital e família), as sociedades de controle começam a tomar o lugar das sociedades disciplinares. O controle, antes exercido pelo confinamento dos corpos, agora se estende aos espaços abertos. Disse Deleuze ([1990] 2008, p. 216):

É certo que entramos em sociedades de 'controle', que já não são exatamente disciplinares. Foucault é com frequência considerado como o pensador das sociedades de disciplina, e de sua técnica principal, o confinamento (não só o

\footnotetext{
${ }^{13}$ É preciso lembrar que Michel Foucault inclui, embora imprecisamente, o século XVII nesse período que situa as sociedades disciplinares. Cf. FOUCAULT, M. [1975] 2004, p. 118 e p. 120, especialmente.
} 
hospital e a prisão, mas a escola, a fábrica, a caserna). Porém, de fato, ele é um dos primeiros a dizer que as sociedades disciplinares são aquilo que estamos deixando para trás, o que já não somos. Estamos entrando nas sociedades de controle, que funcionam não mais por confinamento, mas por controle contínuo e comunicação instantânea.

Uma sociedade que conhece os meios pelos quais o sujeito pode ser motivado e controlado e, circularmente, tem o poder de motivar a produção desse sujeito e controlar sua vida e sua morte, comprando suas ações e dele exigindo comportamentos. Tais características são muito semelhantes àquelas da sociedade de soberania em que o rei tinha sob seu poder a vida e a morte do súdito. Porém, agora, a sociedade de controle não age por imperativos, mas por modulações, como moldagens autodeformantes ${ }^{14}$, realizadas em práticas discursivas (o discurso sobre a avaliação contínua, por exemplo) e não discursivas (correlatamente, a prática da avaliação como processo). Os processos contínuos, intermináveis, porém de rápida rotação, e sempre abertos a outras possibilidades garantem, na sociedade de controle, o adiamento do fim. Segundo Deleuze ([1990] 2008, p. 221), "Nas sociedades de disciplina não se parava de recomeçar (da escola à caserna, da caserna à fábrica), enquanto nas sociedades de controle nunca se termina nada".

Neste estudo, defendemos que nossa sociedade pode já estar funcionando aos moldes da sociedade de controle e, assim, interessa-nos perceber os efeitos discursivos dos princípios moduladores ${ }^{15}$ que, acreditamos, circulam no discurso sobre o LDI.

Talvez já nos situemos numa sociedade de controle que age por dessimbolização. Dany-Robert Dufour ([2003] 2005, p. 199-200) define dessimbolização como "um processo que visa desembaraçar a troca concreta do que a excede ao mesmo tempo em que a institui: seu fundamento". Dufour entende esse "fundamento" como o valor simbólico do objeto de troca e relaciona a dessimbolização à pós-modernidade, especialmente ao que se refere ao "desaparecimento dessa instância que interpela e se dirige a todo sujeito, à qual ele deve

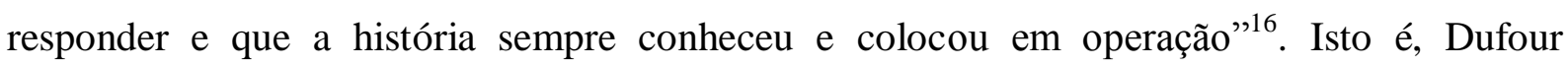
corresponde a pós-modernidade "à ausência, radicalmente nova na história, de grandes Sujeitos"17 e aponta o Mercado como um possível novo grande Sujeito da pós-modernidade, essa instância que nos interpela. Desse modo, Dufour nos leva à relação entre a dessimbolização, pós-modernidade e neoliberalismo, dizendo (DUFOUR, D-R., [2003] 2005, p. 208):

\footnotetext{
${ }^{14}$ DELEUZE, G., [1990] 2008, p. 221.

${ }^{15}$ Dizeres que funcionam como modulações, demandando intermináveis atualizações.

${ }^{16}$ DUFOUR, D-R., [2003] 2005, p. 26.

${ }^{17}$ Ibidem, p. 75.
} 
O que o neoliberalismo quer é um sujeito dessimbolizado, que não esteja mais nem sujeito à culpabilidade, nem suscetível de constantemente jogar com um livre arbítrio crítico. Ele quer um sujeito incerto, privado de toda ligação simbólica; ele tende a instalar um sujeito unissexo e "nãoengendrado", isto é, sem o arrimo de seu fundamento exclusivamente no real $^{18}$, o da diferença sexual e da diferença geracional. Sendo recusada toda referência simbólica suscetível de garantir as trocas humanas, há apenas mercadorias que são trocadas num fundo ambiente de venalidade e de niilismo generalizados no qual somos solicitados a tomar lugar. $\mathrm{O}$ neoliberalismo está realizando o velho sonho do capitalismo. Não apenas ele estende o território da mercadoria até os limites do mundo (o que está em curso sob o nome de mundialização), no qual tudo se tornou passível de ser mercadoria (a água, o genoma, o ar, as espécies vivas, a saúde, os órgãos, os museus nacionais, as crianças...). Ele também está recuperando velhas questões privadas, até agora deixadas à maneira de cada um (subjetivação, personação, sexuação...), para fazê-las entrar na órbita da mercadoria.

Conforme a argumentação de Dufour que destacamos acima, a dessimbolização prevê um sujeito livre de culpa e o objeto de troca desprovido de carga simbólica, sustentando apenas seu valor venal. Contudo, se Dufour entende o valor simbólico do objeto de troca como seu "fundamento", como citamos ${ }^{19}$, isto é, como aquilo que tanto "excede" quanto “institui" o objeto, não nos parece que o valor simbólico possa ser de todo dissociado do objeto, já que o institui, o constitui, o funda. Acreditamos, assim, que a dessimbolização seja um efeito produzido pelas práticas discursivas relativas aos funcionamentos da pósmodernidade e do neoliberalismo. Isso porque vemos que há uma estreita relação entre o valor simbólico, a cultura e a ideologia que não se desfaz no ato da troca do objeto, apenas sofre o efeito do discurso sobre sua venalidade. Em outros termos, o discurso da dessimbolização, como uma prática neoliberal, parece trabalhar no sentido de desprover o objeto de seu valor simbólico para torná-lo ainda mais atraente como uma mercadoria, pois carrega a memória de uma simbolização.

Dufour ([2003] 2005, p. 12) menciona como um exemplo de dessimbolização o caso da mudança do pronome she (feminino) para it (neutro) na denominação dos navios, argumentando que, a partir daí, o navio inglês se tornara um objeto destituído de seu valor simbólico historicamente construído ${ }^{20}$. O editor do jornal Lloyd's List, que demandou a

\footnotetext{
${ }^{18}$ DUFOUR, D-R. refere-se, aqui, ao Real da Psicanálise lacaniana: o impossível de ser simbolizado.

${ }^{19}$ DUFOUR, D-R., [2003] 2005, p. 199-200.

${ }^{20}$ Há muitas versões folclóricas que tentam explicar a denominação feminina para navio em inglês. Dentre elas destacamos: todos os navios ingleses pertencem à rainha e a representam; todos os navios da Marinha Real Britânica têm as iniciais HMS, a abreviação de Her Majesty Ship, e por isso recebem um nome feminino; um navio, como uma mãe ou esposa, acolhe os marinheiros, carregando-os em seu ventre (mãe) ou em seus braços (esposa) etc. Disponível em:< http://www.phrases.org.uk $>$. Acesso em 20 nov. 2013.
} 
mudança do pronome da palavra ship (navio) nos artigos desse diário, afirma tê-lo feito para seguir a tendência dos grandes jornais internacionais e, portanto, alinhar-se à demanda neoliberal. Porém, ao mesmo tempo, ele informa que esperava como resposta dos leitores uma grande variedade de cartas vibrantes ${ }^{21}$. O jornal, então, promoveu a "dessimbolização", isto é, colocou em funcionamento o discurso da dessimbolização do objeto navio e, a partir da memória sobre a simbolização tradicional desse mesmo objeto, o fez atraente aos leitores. Mesmo assim, a mesma reportagem ${ }^{22}$ que publica a entrevista com o editor do Lloyd's List informa que nem a Marinha Real Britânica (Royal Navy) nem a Federação das Indústrias Marinhas Britânicas (British Marine Industries Federation) adotariam a mudança do pronome de she para it, segundo as declarações desses órgãos ao jornal.

Outro caso que podemos associar à dessimbolização como efeito discursivo envolve a recente onda de leilão de virgindade pela internet. A repercussão global e a soma de valores alcançadas nesses leilões não estão no fato de a virgindade feminina ter perdido seu valor simbólico. Ao contrário, o valor simbólico que funda e institui a virgindade como mito, ao mesmo tempo em que é discursivisado como aquilo que excede, é justamente o que suscita o interesse e promove a comoção global. Ao ser tratada como uma mercadoria à disposição do mercado, a virgindade tem seu valor simbólico denegado e é essa mesma denegação que a torna tão atraente. O efeito de dessimbolização dos objetos de troca, historicamente marcados, parece funcionar pela denegação e ser acolhido no discurso da sociedade atual não exatamente pela perda ou extração de seus valores simbólicos, nem pela ausência de instância de validação, mas, acreditamos, pela possibilidade que suscita de atingir essa instância (esse grande Outro) diluída, inconsistente e anuviada.

Nas palavras de Slavoj Žižek ([2004] 2006, p.146), “o Outro deve ser entendido como uma abstração, como se já estivesse morto" e que não deve nos incomodar. Lembramos que Žižek, como exemplo dessa relação do sujeito com o Outro, nos lembra que Lacan atribui ao dinheiro exatamente a função de impedir que o Outro nos incomode. Do mesmo modo que pagamos pelo sexo para não termos envolvimento, fazemos grandes doações em massa para causas humanitárias "para que elas fiquem por lá" (ŽIŽEK, S., [2004] 2006, p.93). Porém, consideramos que esse Outro, que para o sujeito é abstração, se fortifica nessa mesma abstração pela pluralidade ou multiplicidade de modelos, trazendo consigo o poder de controlar sua vida e sua morte, seus passos e seus desejos. Isso porque observamos que, em

\footnotetext{
21 Disponível em: <http://www.telegraph.co.uk/news/uknews/1388373/Lloyds-List-sinks-the-tradition-ofcalling-ships-she.html >. Acesso em: 20 nov. 2013.

${ }^{22}$ Idem.
} 
outro momento, Žižek ([2002] 2003, p. 171) já questionava se o Estado estaria "realmente definhando" ou reafirmando mais fortemente sua autoridade através do "papel crucial no obverso da globalização" desempenhado pelos aparelhos de Estado "(repressivos e ideológicos)", como na guerra contra o terrorismo desencadeada a partir dos ataques aos Estados Unidos em 11 de setembro de 2011. Abstrata, "morta" e não localizável, a instância de validação adentra a vida do sujeito por caminhos múltiplos, sem incomodá-lo nem envolvê-lo, controlando-o incisivamente.

Um último conceito, cuja mobilização no trabalho já aparece imbricada na conceitualização apresentada até agora, é a noção de ideologia. Para Slavoj Žižek, o que nos deve interessar da ideologia não é precisamente aquilo que seu conteúdo afirma, mas "o modo como esse conteúdo se relaciona com a postura subjetiva envolvida em seu próprio processo de enunciação" (ŽIŽEK, S., [1994] 2007, p. 13). Entendemos com isso que a questão não é buscar a verdade ou a falsidade do conteúdo de uma ideologia, mas perceber as formas de subjetivação que essa ideologia pressupõe e/ou constrói e o modo pelo qual ela interpela os indivíduos em sujeitos (PÊCHEUX, M., [1975] 2009, p. 134). Além disso, parece-nos que o real funcionamento de uma ideologia subjaz à transparência ilusória de seu sucesso, pois, segundo Žižek ${ }^{23}$, "para ser eficaz, a lógica de legitimação da relação de dominação tem que permanecer oculta".

Michel Pêcheux ([1975] 2009, p. 134) definiu ideologia como aquilo que interpela o indivíduo em sujeito, insistindo na caracterização de ideologia como práticas, em oposição a ideias $^{24}$. Usando o termo de Althusser, Pêcheux afirmou que os aparelhos ideológicos do Estado "são o lugar e o meio de realização" 25 da ideologia da classe dominante. Ou seja, os aparelhos ideológicos do Estado não apenas produzem ou acolhem a ideologia da classe dominante, mas também servem de "palco" ${ }^{26}$, como o lugar da realização das práticas, para que essa ideologia seja feita e se faça dominante. Segundo Pêcheux ${ }^{27}$, tanto a ideologia quanto o inconsciente têm um caráter comum: "dissimular sua própria existência no interior mesmo do seu funcionamento, produzindo um tecido de evidências 'subjetivas". Pêcheux explica, ainda, que essas "evidências subjetivas" não devem ser entendidas como aquilo que afeta o sujeito, mas como o tecido no qual o sujeito se constitui.

\footnotetext{
23 ŽIŽEK, S., [1994] 2007, p. 14.

${ }^{24}$ PÊCHEUX, M., [1975] 2009, p. 130.

${ }^{25}$ Ibidem, p. 131.

${ }^{26} \mathrm{Cf}$. nota acima.

${ }^{27}$ PÊCHEUX, M., [1975] 2009, p. 139.
} 
Michel Foucault, por sua vez, nunca desejou relacionar seus estudos à questão da ideologia. Dedicando-se à investigação das relações de poder, Foucault conclui que o poder não é algo que se possa possuir; ao contrário, o poder é exercido de modo capilar, microfísico. Ou seja, o movimento das relações de poder não pode ser caracterizado como sendo unilateral de cima para baixo apenas, mas como um movimento circular em que o poder produz e é produzido pelo saber. Foucault define, portanto, o poder como "um conjunto de ações sobre outras ações" (FOUCAULT, M., 1982, p. 220).

É exatamente nesse ponto que apreciamos a possibilidade de fazermos a análise do discurso segundo os preceitos de Michel Pêcheux e, ao mesmo tempo, considerarmos as noções de poder e saber de Michel Foucault. Ou seja, ambos, Pêcheux e Foucault, concentram seus estudos em práticas e ações, respectivamente. Com isso, Pêcheux rejeita definitivamente a noção de ideologia como abstração. Por outro lado, Foucault parece excluir a ideologia de seus estudos justamente por entendê-la como abstração. Portanto, é a própria noção de abstração como o elemento constituinte do sujeito e do discurso que fica excluída tanto do pensamento pecheutiano como do pensamento foucaultiano. Assim, o foco em práticas e ações, ao mesmo tempo em que rejeita a abstração, ressalta a noção de materialidade.

Poderíamos dizer, então, que são as materialidades que constituem o discurso para ambas as teorizações. Para Pêcheux, o discurso é materialidade linguística e materialidade histórica. Para Foucault, há também materialidades nas ações e no discurso, definido por ele como "um jogo" de signos, a "reverberação de uma verdade [um saber] nascendo diante de seus próprios olhos" (FOUCAULT, M., [1970] 2004, p. 49).

Glyn Williams ([1999] 2005) faz várias aproximações entre os métodos de análise de Michel Pêcheux e Michel Foucault, enfatizando que é o trabalho de Foucault, mais do que de qualquer outro pós-estruturalista, que tem vital importância para a $\mathrm{AD}$ francesa. Williams chega a afirmar que os trabalhos de ambos, Pêcheux e Foucault, apresentam partes que se sobrepõem e contribuem para o processo de construção da $\mathrm{AD}$ francesa. Em relação a essa sobreposição, Glyn Williams ([1999] 2005, p. 101) fala sobre as condições de produção do discurso ao definir o trabalho de Michel Pêcheux:

Assim, a sobreposição com o trabalho de Foucault (1969, p. 201) envolve a ligação entre o corpus do material a ser analisado e um contexto institucional definido por 'uma área social, econômica, geográfica ou linguística que possibilita as condições do exercício da função enunciativa'. ${ }^{28}$

\footnotetext{
${ }^{28}$ Nossa tradução para WILLIAMS, G. ([1999] 2005, p. 101): “Thus the overlap with the work of Foucault (1969, p. 201) involves the link between the corpus of material to be analysed and an institutional context which
} 
Em outros momentos de seu texto ${ }^{29}$, Williams defende a pluralidade autoral da constituição da $\mathrm{AD}$ francesa, já narrada por tantos outros autores ${ }^{30}$, para enfatizar as contribuições dos pensamentos foucaultianos nos trabalhos desenvolvidos por Michel Pêcheux. Na mesma obra, em nota à página 102, Williams aproxima o conceito de posição sujeito em ambos os autores ao relacioná-lo à formação discursiva:

Novamente, vemos que os primeiros trabalhos da $\mathrm{AD}$ francesa focavam no modo como uma formação discursiva define os campos e 'pontos de origem' enunciativos, não como uma forma de subjetividade, mas como um lugar em que os enunciadores são substituíveis, apontando, mais uma vez, ao dizer de Foucault (1969) sobre a posição que se deve ocupar para ser o sujeito daquele discurso. ${ }^{31}$

Considerando o caráter dissimulado do funcionamento da ideologia, Williams conclui:

Uma vez que se reconhece que a ideologia não é concebida como um processo conspirativo, a diferença entre Pêcheux e Foucault é reduzida à relevância da estrutura de classe como a característica dominante da sociedade. $^{32}$

Finalmente, Williams nos lembra, também, que Courtine ${ }^{33}$ ([1981] 2009, p. 82) afirma: “reler Foucault não é 'aplicá-lo' à $\mathrm{AD}$, é trabalhar sua perspectiva no interior da AD". Neste nosso trabalho, que observa os conceitos da linha pecheutiana, as noções de poder e saber de Michel Foucault nos fornecem a perspectiva necessária para delinearmos nossas categorias de análise.

É importante ressaltar que, no percurso deste trabalho, poderemos ter recorrido a outros conceitos cuja relevância não conseguimos antecipar para o leitor neste momento, mas que serão explicitados localmente.

is defined by 'a social, economic, geographic or linguistic area giving the conditions of the exercise of enonciative function'.

${ }^{29}$ Cf. WILLIANS, G. ([1999] 2005) p. 100, 101, 102, principalmente.

${ }^{30}$ Sobre os grupos de autores que juntos trabalharam dentro dos contornos da AD francesa, veja os trabalhos de JACQUES GUILHAUMOU, RÉGINE ROBIN, DENISE MALDIDIER, entre outros.

${ }^{31}$ Nossa tradução para WILLIAMS, G., ([1999] 2005, p. 102): "Again we shall see that the early work of FDA focused on the manner in which a discursive formation defines fields and enonciative 'points of origin', not as a form of subjectivity, but as a place for which the enonciateurs are substitutable, again leading to Foucault's (1969) dictum concerning the position which has to be occupied in order to be the subject of that discourse".

${ }^{32}$ Nossa tradução para WILLIAMS, G., ([1999] 2005, p. 118): "Once it is recognised that ideology is not conceived of as a conspiratorial process, the difference between Pêcheux and Foucault is reduced to the relevance of the class structure as the dominant feature of society".

${ }^{33}$ É preciso lembrar que Courtine, nesse mesmo texto (COURTINE, J-J, [1981] 2009, p. 69), declara: "De fato, Foucault foi pouco ouvido pela AD; embora seja do discurso que fale, ele o faz de outro modo". 
Ao observarmos os conceitos da Análise do Discurso pecheutiana, devemos lembrar que a $\mathrm{AD}$ trata da análise das materialidades linguística e histórica de seu objeto (o discurso), tem a linguística como pressuposto e a interdisciplinaridade como base ${ }^{34}$. Não há, em $\mathrm{AD}$, a separação entre forma e conteúdo, ou entre a estrutura e o acontecimento, visto que o discurso em si é produto da soma de ambos. O analista se coloca, então, entre a descrição e a interpretação ${ }^{35}$, procurando perceber efeitos de sentido no discurso que analisa. A própria definição de discurso já nos remete à questão dessa percepção. O discurso é definido como "efeito de sentidos entre locutores"36. Assim, nossa pesquisa se propõe a perceber sentidos a partir da observação do funcionamento discursivo dos dizeres do corpus.

Nossa proposta é analisar o discurso sobre o livro didático para o ensino de inglês como língua estrangeira e, para isso, construímos nosso corpus a partir de três segmentos: oficial, profissional e midiático. A análise dos dizeres do segmento oficial nos ajuda a perceber o modo de funcionamento que é esperado do livro didático de inglês em nossa sociedade na visão dos órgãos responsáveis (MEC - Ministério da Educação e Cultura - e FNDE - Fundo Nacional de Desenvolvimento da Educação). O segmento do discurso profissional oferece ao trabalho o olhar imprescindível e determinante do professor em dois momentos distintos: antes e após a adoção do LDI do PNLD 2011. Já o discurso midiático contribui, na sua presença e na sua ausência, como veremos ${ }^{37}$, à percepção de outros sentidos que compõem a representação do livro didático de inglês e seu modo de funcionamento na nossa sociedade. Informamos, abaixo, os dados objetivos sobre os materiais comportados em cada um dos três segmentos do corpus de pesquisa.

O segmento oficial foi composto por documentos, tais como: o Decreto-Lei NP 8.460 de 26 de dezembro de 1945, conhecido como o artigo $5^{38}$, sobre as determinações acerca do livro didático na escola pública brasileira; o Edital de Convocação para Inscrição no Processo de Avaliação e Seleção de Coleções Didáticas para o Programa Nacional do Livro Didático - PNLD 2011; a Carta Senha, para $\log$ in; as Orientações para o registro da escolha do PNLD 2011 ( $6^{\circ}$ ao $9^{\circ}$ ano); a Nota de Esclarecimento sobre o PNLD 2011; e finalmente, o Guia de Livros Didáticos - PNLD 2011, com os resultados da seleção dos livros a serem utilizados no período de três anos, de 2011 até o final de 2013. Foram usados,

\footnotetext{
${ }^{34}$ Cf. BRANDÃO, H., 2004.

${ }^{35}$ Cf. ORLANDI, E. 1999.

${ }^{36}$ Ibidem, p. 21.

${ }^{37}$ Muitos informes midiáticos apenas repassam as informações disponibilizadas pelos órgãos oficiais, abstendose de sua tarefa investigativa.

${ }^{38}$ Pelo Decreto-Lei $\mathrm{n}^{\circ} 8.460$, de 26/12/45, é consolidada a legislação sobre as condições de produção, importação e utilização do livro didático, restringindo ao professor a escolha do livro a ser utilizado pelos alunos, conforme definido no art. $5^{\circ}$.
} 
ainda, como fonte de informação e apoio para nossa análise desse segmento, os textos oficiais do Fundo Nacional de Desenvolvimento da Educação (a partir de agora, FNDE) sob os títulos de Valores Negociados e Resumo Físico Financeiro do PNLD 2011; além da Resolução no 60 de 20 de Novembro de 2009, que estabelece a abrangência do programa estendida aos materiais de língua estrangeira, e sua substituta, a Resolução no $\mathbf{1 0}$ de 10 de março de 2011.

Uma questão que a proposta de adoção de um número limitado ${ }^{39}$ de coleções didáticas para o ensino de inglês em todo o país já delineia neste momento é a percepção do Brasil como um espaço social e geográfico homogêneo. Desse modo, podemos observar, no desenrolar deste trabalho, a contradição entre a ilusão de o Brasil ser um território homogêneo e o discurso a favor do respeito à diversidade que parece alinhavar o discurso oficial. Considerando-se que o escopo do Programa Nacional do Livro Didático, dos documentos emitidos pelo MEC para a adoção do primeiro LDI no Brasil, informados acima, e do processo de adoção desse LDI abrange todo o território nacional brasileiro, os demais segmentos do corpus de pesquisa esforçam-se em contemplar tantos espaços geográficos (municípios e estados) quanto pudemos adentrar através da coleta de materiais para a análise.

O segmento profissional contém as respostas a dois questionários, ambos com cinco perguntas, que elaboramos para colher os dados junto a professores do $6^{\circ}$ ao $9^{\circ}$ ano da rede pública de ensino. Os professores que responderam aos questionários nos foram indicados por nossos contatos pessoais e profissionais. O primeiro questionário foi respondido em 2010, antes da adoção do LDI, por um total de dezessete professores de escolas públicas municipais, estaduais e outras não informadas, das cidades de São Paulo, Carapicuíba, Sorocaba, São Bernardo do Campo, Diadema (situadas no estado de São Paulo), Campina Grande (PB) e Santa Terezinha (PE), perfazendo um total de aproximadamente ${ }^{40}$ quinze escolas. Alguns professores nos entregaram pessoalmente os questionários respondidos manualmente; outros receberam e nos devolveram os questionários digitados via internet. O segundo questionário foi respondido entre o segundo semestre de 2012 e o primeiro semestre de 2013, já com o uso do LDI nas escolas, por vinte e oito professores de inglês, também do $6^{\circ}$ ao $9^{\circ}$ ano do Ensino Fundamental da rede pública de ensino. Os questionários foram respondidos por professores das cidades de Itapecerica da Serra e Itaquaquecetuba (SP), Brumadinho e Belo Horizonte (MG), Campina Grande e João Pessoa (PB), Araguaína, Muricilândia, Piraquê, Buriti do Tocantins, Nazaré e Ananás (TO) e Paranoá (DF). Alguns desses questionários foram enviados e devolvidos via internet; outros foram entregues em papel aos professores e

\footnotetext{
${ }^{39}$ Duas coleções didáticas de língua inglesa foram aprovadas para participarem do PNLD 2011.

${ }^{40}$ Foi possível saber que as escolas cujos nomes não foram informados não eram coincidentes.
} 
devolvidos pelo correio. Os questionários respondidos pelos professores de Tocantins foram coletados durante o evento da APLINTINS - Associação de professores de língua inglesa do estado do Tocantins - 19th English Teaching Seminar - Teaching and Learning English: practices, perspectives and challenges, ocorrido em 17 e 18 de agosto de 2012.

Salientamos que, para a presente investigação, julgamos suficiente que o perfil dos respondentes se restringisse à condição de serem professores ou professoras de inglês que atuassem em um ou mais anos do segmento do $6^{\circ}$ ao $9^{\circ}$ ano da escola pública brasileira. Lembramos, também, que não conhecemos os respondentes pessoalmente e que seus dados pessoais não nos foram informados de modo algum. Durante a análise dos dizeres desses professores, não indicaremos seus lugares de pertencimento, pois estamos considerando que todos esses professores trabalhariam (respondentes ao primeiro questionário) ou trabalham (respondentes ao segundo questionário) com uma das duas coleções adotadas em âmbito nacional. Nesse sentido, já podemos dizer que o programa de adoção do primeiro LDI no Brasil, apesar de declarar o contrário, considerou tanto as duas coleções aprovadas como também os professores, os alunos, os contextos educacionais, sociais etc. como elementos homogêneos. Acreditamos, no entanto, que, sendo a heterogeneidade constitutiva do discurso, ela se apresenta nos dizeres dos sujeitos sendo eles da mesma escola, cidade, estado ou de lugares diferentes. Justificamos, ainda, esse nosso procedimento em relação ao perfil dos respondentes pela percepção de que a $\mathrm{AD}^{41}$ considera o sujeito como sendo uma posição ocupada pelo indivíduo no momento em que se faz sujeito de seu dizer. É importante também considerar que cada indivíduo ocupa tal posição de modo singular, heterogêneo, pois é chamado a ocupar esse lugar pela ideologia com que se identifica. Desse modo e considerando que sempre haverá heterogeneidade, os sujeitos cujos dizeres analisamos ocupam a posição de professores de inglês da rede pública de ensino brasileira e dedicam-se a um ou mais anos do segmento do $6^{\circ}$ ao $9^{\circ}$ ano; por outro lado, as características relativas aos indivíduos que participaram da pesquisa são desconhecidas.

O segmento midiático do corpus de pesquisa foi composto por textos disponibilizados na internet por duas agências de notícias que se propõem a publicar informativos municipais (www.amarildomelo.com.br, da cidade de Brasileira, PI) e estaduais (www.portalct.com.br; Palmas, TO); pelo site da SECD - Secretaria de Educação, Cultura e Desportos, Governo do Estado de Roraima e da ANDIFES - Associação Nacional dos Dirigentes das Instituições de

${ }^{41}$ Cf. ORLANDI, E. 1999, p. 49: "é a posição que deve e pode ocupar todo indivíduo para ser sujeito do que diz"; cf. FOUCAULT, M. [1969] 2008, p. 130: "um sujeito (não a consciência que fala, não o autor da formulação, mas uma posição que pode ser ocupada, sob certas condições, por indivíduos indiferentes)". 
Ensino Superior; e pelas agências de notícias on line não governamentais: 45 graus, de Teresina, Piauí; Agência de notícias Primeira Hora, Rondonópolis, Mato Grosso; Agência de notícias Terra, Terra Networks Brasil S.A., Porto Alegre, Estado do Rio Grande do Sul; Agência Brasileiracity, Brasileira, PI; Agência WSCom, João Pessoa, PB; e Folha.com de São Paulo. Utilizamos, também, os textos publicados nos sites de duas escolas públicas estaduais: Escola Estadual Professor Gerson Lopes, Apodi, RN, sobre a quantidade insuficiente de livros de inglês recebidos, e da Escola Estadual Dr. Euzébio Dias Bicalho de Belo Horizonte, MG, sobre o não recebimento do material de inglês e as mensagens de correspondência que trocamos. Também neste segmento do corpus de pesquisa, procuramos por notícias sobre o LDI do PNLD 2011 em diferentes regiões geográficas do país, considerando-se o escopo do programa de adoção do LDI.

Como dissemos, durante a análise dos dizeres compreendidos nesses segmentos, buscamos por representações e outros efeitos discursivos que nos auxiliaram a responder às nossas perguntas de pesquisa.

Na primeira parte do trabalho, situamos o livro didático de inglês historicamente no contexto educacional brasileiro. Através de breve percurso histórico, observamos o papel do livro didático desde o período da colonização portuguesa até o atual. Ainda nesse primeiro capítulo, são observados alguns aspectos do funcionamento das concepções naturalizadas do livro didático de inglês em estudos acadêmicos atuais, desenvolvidos no período de 2007 a 2013. No segundo capítulo, observamos as relações entre o livro didático - agora, de modo geral, e não apenas o livro didático de inglês - e o poder regulador do Estado. A participação do mercado editorial no processo de adoção do LDI é discutida no segundo item desse mesmo capítulo e, no item seguinte, tratamos do programa do LDI na escola pública brasileira. Em seguida, discutimos o conceito de disciplina em relação ao movimento de transformação histórica da sociedade ocidental. O efeito de poder de discurso de verdade do livro didático é discutido também nesse capítulo. Antes de finalizarmos essa primeira parte, ainda no capítulo dois, apresentamos uma breve discussão, um tanto teórica, mas que advém da análise que cronologicamente a precedeu - como é próprio das investigações no âmbito da $\mathrm{AD}$ - sobre alguns aspectos do discurso sobre o LDI e sua relação com o discurso do LDI. Essa discussão tem o objetivo de distinguir o discurso sobre algo ou alguém em relação ao discurso de algo ou alguém, caracterizando-o como um outro discurso ou, como argumentaremos em 2.6.3, uma outra categoria discursiva. Ao final do capítulo dois, trabalhamos a relação entre discurso e sociedade de controle. Essas breves discussões nos auxiliam no embasamento da análise desenvolvida na segunda parte do trabalho. 
A parte dois, portanto, é dedicada à análise discursiva dos dizeres dos três segmentos do corpus de pesquisa. No capítulo três, apresentamos as categorias de análise, desenvolvidas a partir da conceitualização foucaultiana sobre poder e saber, e as diretrizes que guiam nossas observações sobre o funcionamento da sociedade de controle nos dizeres que analisamos em cada categoria. No capítulo quatro, trabalhamos com a primeira categoria de análise, que observa a noção de poder como um conjunto de ações sobre outras ações ${ }^{42}$. Nesse capítulo, procuramos observar se e, em caso afirmativo, como o discurso sobre o LDI representa o LDI como um poder; isto é, como um conjunto de ações sobre outras ações. O capítulo cinco observa a noção de saber como verdade. Com a segunda categoria de análise, "Um conjunto de procedimentos regulados para a produção, a lei, a repartição, a circulação e o funcionamento dos enunciados" (FOUCAULT, M., [1979] 2004, p. 14), pesquisamos se e também como o LDI é representado como esse conjunto de procedimentos, ou seja, como a verdade. A terceira categoria nos auxilia a analisar os dizeres no capítulo seis, considerando a articulação da relação saber-poder, para percebermos se é possível que o discurso sobre o LDI invista poder de verdade no LDI.

Apresentamos, a seguir, o texto correspondente à primeira parte deste trabalho, situando o livro didático de inglês historicamente no contexto educacional brasileiro.

\footnotetext{
${ }^{42}$ Cf. FOUCAULT, M., 1982, p. 220: "A set of actions upon other actions".
} 
PARTE 1

O LIVRO DIDÁTICO DE INGLÊS 


\section{CAPÍtULO 1}

\section{O CONTEXTO HISTÓRICO}

Este primeiro capítulo deseja situar o livro didático de inglês historicamente no contexto da educação no Brasil, acompanhando seu percurso de instauração no âmbito do ensino e atentando ao modo como as concepções sobre o LDI têm contribuído, ao longo do tempo, para naturalizar o sentido da necessidade de adoção do livro didático de inglês em nossa sociedade. Em um primeiro momento, buscamos recuperar brevemente o percurso histórico do livro de inglês em relação à história do Brasil. Para isso, retomamos um pouco da história do ensino de línguas, inserindo aí, principalmente, a língua inglesa desde o início da nossa colonização por Portugal e o caminho do livro didático de inglês nessa história.

Num outro momento, observamos estudos de pesquisa desenvolvidos nos últimos anos, a partir de 2007 até 2013, que se dedicaram a examinar o LDI no Brasil. Esses estudos nos fornecem concepções naturalizadas sobre o livro didático de inglês no Brasil, como discursos que circulam em torno do LDI, e nos permitem observar quais aspectos do LDI atraem os estudos acadêmicos desenvolvidos no Brasil que abordam o livro didático de inglês.

\subsection{Percurso histórico}

A história tem valor inestimável para os estudos discursivos justamente por sua contribuição à própria construção do discurso que se analisa. Ao pensarmos o nível do interdiscurso como o lugar da história, incluímos aí, mas não somente, a história como construto - sempre reformulável e reformulado pela interpretação - que dispõe sobre os fatos históricos. Portanto, no eixo dos enunciados, lugar do interdiscurso, ao lado da memória e do já-dito, também estão os dizeres sobre os fatos historicamente construídos, ou a história, nesse sentido mais comum.

O estudo aprofundado dos dizeres sobre o livro didático de inglês em sua dimensão histórica é, sem dúvida, muito instigante; porém, ultrapassa o escopo limitado deste trabalho. Neste momento, os fatos históricos oferecem sua contribuição ao trabalho na medida em que nos auxiliam a esboçar o panorama em que se desenvolveu a relação do livro didático de inglês e o ensino de língua inglesa em nossa sociedade.

O livro didático de inglês marca sua presença na história do Brasil principalmente após a chegada da Família Real portuguesa neste país, então colônia, em 1808. Com a criação da cadeira de língua inglesa em 1809, o ensino dessa língua é oficializado. Os primeiros livros 
de inglês utilizados são assinados por autores portugueses e publicados na Inglaterra e em Portugal.

Ainda neste primeiro momento, traçamos algumas relações entre o livro didático e o poder regulador do Estado e entre a disciplina de inglês e a sociedade.

\title{
$1.2 \mathrm{O}$ ensino de inglês no Brasil
}

Sabe-se que o inglês não foi a primeira língua estrangeira ensinada no Brasil. $O$ português, a primeira língua estrangeira em solo brasileiro de que se tem notícia, foi imposto aos nativos brasileiros de modo tão contundente que, além de reprimir ${ }^{43}$ as línguas nativas locais, como o tupi-guarani, e mais tarde a língua geral paulista, foi estabelecida como língua oficial $^{44}$.

Com a chegada da Família Real no Brasil, em 1808, o português tornou-se oficialmente a língua nacional, representativa da unidade imaginária do país e suas línguas. No ano seguinte, D. João VI autoriza a criação da Cadeira Pública de língua inglesa através da Decisão n. 29, de 14 de julho, juntamente com as cadeiras de língua francesa, álgebra, aritmética e geometria. A ementa ${ }^{45}$ sobre o documento de 22 de junho de 1809 informa:

\begin{abstract}
Ementa: requerimento de João Batista feito à Mesa do Desembargo do Paço pedindo provimento na Cadeira de Geometria da Corte. Segundo o parecer do desembargador do Paço Luiz José De Carvalho e Melo, como cabia à Mesa a direção dos estudos e escolas menores a partir do decreto de 17 de janeiro do mesmo ano, e considerando o estudo da Matemática indispensável para os que "desejarem distinguir-se nas diferentes ocupações, e empregos da sociedade", resolvia criar três cadeiras, a da Aritmética, de Geometria e de Trigonometria na Corte e nomear o bacharel padre João Batista para a classe que havia solicitado, por ser ele formado na Universidade de Coimbra. Listava ainda os conteúdos que deveriam ser estudados em cada disciplina, e sugeria a criação de uma cadeira de francês e outra de inglês por sua "conhecida necessidade, e utilidade".
\end{abstract}

Nos anos que se seguiram, os estudos das Línguas Vivas, francês e inglês, objetivaram a capacitação para a leitura de manuais científicos escritos nessas línguas. Em 1837, é criado no Rio de Janeiro o Colégio Pedro II, apresentando o inglês e o francês, além do latim e do grego, em sua grade curricular.

Até antes da Proclamação da República em 1889, o provimento de cadeiras, os objetivos dos estudos e todas as ações relacionadas ao ensino, como as indicações dos

43 Mesmo assim, há hoje aproximadamente 180 línguas indígenas faladas no Brasil. Cf. $\langle$ http://pib.socioambiental.org/pt/c/no-brasil-atual/linguas/troncos-e-familias $>$. Acesso em: 18 mar. 2011.

${ }^{44} \mathrm{Cf}$. $\langle$ http://www.labeurb.unicamp.br/elb/portugues/portugues brasil.htm>. Acesso em: 16 fev. 2011.

${ }^{45} \mathrm{Cf}$. 〈http://www.historiacolonial.arquivonacional.gov.br〉. Acesso em: 25 fev. 2011. 
professores etc., eram feitos através de instrumentos legais submetidos à aprovação do soberano (regente ou imperador). Com a Primeira República (1889 - 1930), os rumos do ensino passam à direção ministerial. O Decreto n. 1.075, assinado por Benjamin Constant em 22 de novembro de 1890, estabelece o francês como língua estrangeira obrigatória. O inglês (e também o alemão) é oferecido como disciplina opcional, tornando-se obrigatório já no fim do século $\mathrm{XIX}^{46}$.

A oficialização do órgão responsável pela educação no Brasil só se dá em 14 de novembro de 1930, com a criação da Secretaria de Estado denominada Ministério dos Negócios da Educação e Saúde Pública através do Decreto $19.402^{47}$. A partir de 1931, sob o governo provisório do Presidente Vargas, a educação passa por novas reformas. Uma série de decretos que almejavam a organização do ensino secundário e das universidades, assinados pelo Ministro Francisco Campos ${ }^{48}$ do recém-criado Ministério dos Negócios da Educação e Saúde (1930), ficou conhecida como a Reforma Francisco Campos.

A reforma do Ensino Secundário se dá através dos Decretos n. 19.890 de 18 de abril de 1931 e n. 21.241 de 04 de abril de $1932^{49}$, como parte da Reforma Francisco Campos. Foi, então, estabelecido o currículo seriado, a organização em dois ciclos (fundamental e complementar), necessários para o ingresso no ensino superior, além da frequência que passa a ser obrigatória. O ciclo fundamental, com cinco séries, apresentava a disciplina de inglês nas segunda, terceira e quarta séries, juntamente com o francês. Na primeira série desse ciclo, apenas o francês era obrigatório. Na quinta série, o latim era obrigatório e o alemão opcional. O ciclo complementar destinava-se aos candidatos aos cursos superiores e tinha duração de dois anos. Em alguns cursos do ciclo complementar, como o preparatório para ingresso em cursos de medicina, odontologia e farmácia, era obrigatório frequentar a disciplina de alemão ou de inglês ${ }^{50}$.

Seguido do Decreto 19.851, de 11 de abril de 1931, que instituiu o Estatuto das Universidades Brasileiras, dispondo sobre a organização do ensino superior no Brasil e adotando o regime universitário, o Decreto 19.852, de mesma data, dispôs sobre a organização da Universidade do Rio de Janeiro. Ainda em 21 de dezembro de 1931, outro

\footnotetext{
${ }^{46}$ Cf. História do Ensino de Línguas no Brasil - Projeto do Programa de Pós-Graduação em Linguística Aplicada da Universidade de Brasília. Disponível em: 〈www.helb.org.br〉. Acesso em: 29 ago. 2010.

${ }^{47}$ Cf. 〈http://portal.mec.gov.br/arquivos/pdf/d19402.pdf〉. Acesso em: 15 fev. 2013.

${ }^{48}$ Francisco Campos deixou o Ministério da Educação em setembro de 1932. Em dezembro de 1935, foi nomeado Secretário de Educação do Distrito Federal, substituindo Anísio Teixeira.

${ }^{49}$ Ambos compõem a Reforma Francisco Campos. O Decreto n. 21.241 de 4 de abril de 1932 consolida e complementa o anterior (n. 19.890 de 18 de abril de 1931). Cf. nota abaixo.

${ }^{50}$ Cf. decretos da Reforma Francisco Campos. Disponível em: 〈http://www.histedbr.fae.unicamp.br〉. Acesso em: 28 fev. 2011.
} 
decreto, Decreto n. 20.833, oficializou o Método Direto para o ensino das línguas vivas ${ }^{51}$. Conforme esclarecem Oliveira e Cardoso (2009), "Segundo o novo método, o significado das palavras estrangeiras deveria ser obtido não pela tradução de sua equivalente em português, mas pela ligação direta do objeto à sua expressão",52.

Em 1932, o Manifesto dos Pioneiros da Educação Nova, documento redigido e assinado por educadores conceituados ${ }^{53}$, trazia a proposta de um plano geral de educação organizado pelo Estado, que deveria defender a escola única, pública, obrigatória, laica e gratuita. Nesse período, a Igreja e o Estado disputavam a área da educação.

Durante o governo provisório de Vargas, a constituição de 1934 reconheceu a educação gratuita como direito para todos, delegou a organização e a manutenção das escolas $\operatorname{aos}_{\text {estados }}^{54}$ e reafirmou a proposta do Conselho Nacional de Educação para a criação do Plano Nacional de Educação, que deveria ser aprovado pelo Legislativo. Em 1934, também, é criada a Universidade de São Paulo, a primeira criada e organizada segundo as normas do Estatuto das Universidades Brasileiras de 1931, e a Universidade de Porto Alegre no Rio Grande do Sul.

É interessante notar que nessa mesma década surgem os primeiros cursos livres para o ensino de inglês, apoiados por órgãos oficiais de suas nações. Em 1934, a embaixada britânica inaugura a Sociedade Brasileira de Cultura Inglesa no Rio de Janeiro; em 1938, em São Paulo, o consulado americano formaliza a instituição binacional que conhecemos hoje pelo nome de União Cultural Brasil - Estados Unidos.

Com o Estado Novo (1937 - 1945), houve uma organização da educação ainda mais profunda do que aquela iniciada por Francisco Campos. As competências municipais, estaduais e federais foram definidas e o ensino profissionalizante foi implantado ${ }^{55}$. Gustavo Capanema, Ministro da Educação e Cultura desde 1934, realizou novas reformas na educação.

\footnotetext{
${ }^{51}$ Cf. 〈www.helb.org.br>. Acesso em: 20 fev. 2011.

52 É importante reforçar que os autores OLIVEIRA, L. e CARDOSO, J. (2009), não consideram a reforma educacional de 1931 como "divisor de águas" para estudos históricos, uma vez que, como afirmam, a constituição do ensino de línguas vivas "depende das condições políticas, pedagógicas e culturais em que se configura" e não depende exclusivamente do método de ensino, apesar de estar a ele relacionada. Também VIDOTTI, J.J.V. (2012) se posiciona contra essa divisão do ensino de línguas estrangeiras no Brasil que tem como base a reforma de 1931. Para ela, tal divisão estaria apagando "dizeres em torno do lugar das LE no século XIX”; dentre esses dizeres inclui-se a própria Decisão n. 29 que, como vimos, cria a Cadeira Pública de língua inglesa.

${ }^{53} \mathrm{O}$ documento foi redigido por Fernando de Azevedo e assinado por Anísio Teixeira, Cecília Meirelles, Afrânio Peixoto e Roquette Pinto, entre outros. Disponível em: 〈http://www.pedagogiaemfoco.pro.br/heb07a.htm>. Acesso em: 25 fev. 2011.

${ }^{54}$ Cf. 〈http://www.histedbr.fae.unicamp.br>. Acesso em: 27 fev. 2011.

55 Os objetivos do ensino profissionalizante diferiam daqueles do ensino secundário em seus alcances e organização. Enquanto o ensino profissionalizante era direcionado à classe trabalhadora nas áreas comercial, industrial e agrícola, o ensino secundário objetivava preparar a classe média para funções técnicas e burocráticas
} 
Apesar de, já em 1929, ter sido criado um órgão específico para legislar sobre as políticas do livro didático ${ }^{56}$, com o objetivo de contribuir para a legitimação do livro didático nacional e aumentar sua produção, apenas em 1934, quando Gustavo Capanema assume o Ministério da Educação e Cultura, o Instituto Nacional do Livro (INL) ${ }^{57}$ recebe suas primeiras atribuições: editar obras literárias, elaborar uma enciclopédia e um dicionário nacionais e aumentar o número de bibliotecas públicas. Mesmo assim, muitas fontes indicam o ano de 1929 (Fundo Nacional de Desenvolvimento da Educação - FNDE ${ }^{58}$ ) e outras apontam o ano de 1937 como sendo a data de criação do INL. Oficialmente, segundo o site do Senado Federal $^{59}$, o INL foi criado pelo Decreto-Lei $n^{\circ}$ 93, de 21 de Dezembro de 1937 e extinto em 1990, no governo Collor. O documento Exposição de Motivos ${ }^{60}$, assinado por Capanema e datado de 15 de novembro de 1937, justifica a necessidade da criação do INL e foi publicado no Diário Oficial da União em 27 de dezembro de 1937, página 25586 - Seção 1, e diz:

\section{EXPOSIÇÃO DE MOTIVOS}

Rio de Janeiro - Em 15 de dezembro de 1937

Sr. Presidente - O livro é, sem dúvida, a mais poderosa creação do engenho humano. A influência que ele exerce, sob todos os pontos de vista, não tem contraste.

O livro não é só companheiro amigo, que instrue, que diverte, que consola. É ainda e sobretudo o grande semeador, que, pelos seculos afora, vem transformando a face da terra. Encontraremos sempre um livro no fundo de todas as revoluções.

É, portanto, dever do Estado proteger o livro, não só promovendo e facilitando a sua produção e divulgação, mas ainda vigilando no sentido de que ele seja, não o instrumento do mal, mas sempre o inspirador dos grandes sentimentos e das nobres causas humanas.

Para tais objetivos, seria conveniente a creação do Instituto Nacional do Livro. Submeto á elevada consideração de V. Ex. um projeto de decreto-lei, dispondo sobre a matéria.

Reitero-lhes os meus protestos de respeitosa estima.

- Gustavo Capanema.

ou para o ingresso no ensino superior. Cf. BRITO, S. H. A., A educação no projeto nacionalista do primeiro governo Vargas (1930-1945). In: Navegando na história da educação brasileira - HISTEDBR. Universidade Estadual de Campinas. $\langle$ http://www.histedbr.fae.unicamp.br/navegando/artigos_frames/artigo_101.html $>$. Acesso em: 28 fev. 2011. ${ }^{56} \mathrm{Cf}$. $<$ http://www.fnde.gov.br/programas/livro-didatico/livro-didatico-historico $>$. Acesso em: 27 fev. 2011.

${ }^{57}$ Diz o Decreto-lei 93 de 21/12/1937: Transforma o Instituto Cairu em Instituto Nacional Do Livro - INL (art. 44). Cf. $\quad$ http://legislacao.planalto.gov.br/legisla/legislacao.nsf/Viw Identificacao/lei\%203781937? OpenDocument>. Acesso em: 16 fev. 2013.

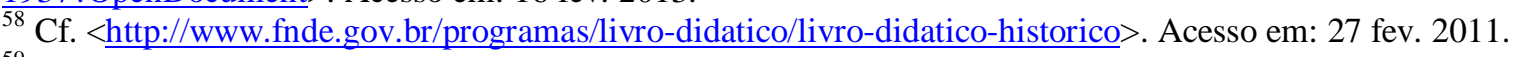

59 Disponível em: $<$ http://www6.senado.gov.br/legislacao/ListaTextoIntegral.action?id=76500\&norma=103227>. Acesso em: 18 fev. 2013.

60 Disponível em: <http://www2.camara.leg.br/legin/fed/declei/1930-1939/decreto-lei-93-21-dezembro-1937350842-exposicaodemotivos-75476-pe.html >. Acesso em: 18 fev. 2013. 
É interessante observar o modo como o livro é representado nos dizeres desse documento. Ao exaltar o poder semeador, transformador, mobilizador e até revolucionário do livro, os dizeres mobilizam essa mesma exaltação como justificativa para que se faça o controle ("proteger o livro"), "vigilando" o livro, para que ele tenha tais fins e não outros. Ou seja, segundo os dizeres desse documento, é preciso vigiar aquilo que o livro irá semear, transformar, mobilizar e revolucionar, para que, ao fazê-lo, não mude os valores que já temos assumidos como representantes do bem e que não seja ele "o instrumento do mal". Portanto, entendemos que esses dizeres constroem uma representação de livro didático como um saber (a ser controlado) que produz poder. Isto é, se o livro é capaz de exercer tal poder na sociedade, é preciso vigiá-lo de perto, através de leis para assegurar os fins desejados.

A Reforma Capanema consistia de uma série de decretos-lei elaborados por um grupo presidido por Gustavo Capanema. Esses decretos-lei eram, então, outorgados pelo Presidente Getúlio Vargas. A proposta da Reforma Capanema, ou Leis Orgânicas de Ensino, resultou de um questionário com duzentas e treze perguntas sobre o ensino, para que, a partir das respostas, o Plano Nacional de Educação fosse elaborado.

Em 1936, esse questionário, intitulado Questionário para um inquérito ${ }^{61}$, foi distribuído pelo Ministro Capanema para membros de todos os setores da sociedade: alunos, professores, jornalistas, membros da igreja, pesquisadores, militares e políticos. O questionário provocou grande interesse da sociedade que viu, ali, um modo de garantir seus princípios, valores e interesses. A Confederação Católica de Educação apresentou um único documento, resultante de uma série de conferências especialmente elaboradas para esse fim. O exército também elaborou seu documento único, através das opiniões dos militares colhidas pela revista A Defesa Nacional, que posteriormente foi enviado ao Estado-maior do Exército. Sobre o questionário, Schwartzman, Bomeny e Costa ${ }^{62}$ ([1984] 2000, p. 194) dizem:

O questionário reavivaria o debate em torno do monopólio oficial do ensino, da escola secundária única, do ensino religioso, do espírito da Constituição de 34, da finalidade da educação. Em seu conjunto parecia preocupar-se menos em traçar as diretrizes gerais para a educação, como estava previsto pela Constituição, e muito mais em definir condições e procedimentos que permitissem à União o total controle, fiscalização e direção da ação educacional em todo o país. Parecia pretender definir não as diretrizes gerais para a educação, mas um código, no sentido jurídico do termo.

\footnotetext{
${ }^{61}$ O Questionário para um inquérito, Rio de Janeiro, Imprensa Nacional, 1936, faz parte do arquivo de Gustavo Capanema, depositado no Centro de Pesquisa e Documentação de História Contemporânea do Brasil (Cpdoc) da Fundação Getúlio Vargas.

${ }^{62}$ Cf. SCHWARTZMAN, S.; BOMENY, H. M. B.; COSTA, V. M. R., [1984] 2000. Tempos de Capanema. Disponível em: <http://www.schwartzman.org.br/simon/capanema/introduc.htm>. Acesso em: 11 fev. 2013.
} 
No sentido jurídico do termo, um código é uma lei ou um conjunto de princípios e normas, portanto, um instrumento legal com muito mais força para controlar e modelar do que programas e diretrizes. Ainda segundo esses autores, a principal preocupação do ministério era montar uma máquina burocrática, com a qual fosse possível "centralizar, coordenar e controlar a educação em todo o território nacional" (SCHWARTZMAN, S.; BOMENY, H. M. B.; COSTA, V. M. R., [1984] 2000, p. 194).

Em 1937, Capanema recebe do Conselho Nacional de Educação o texto final do Plano Nacional de Educação, que é enviado pelo presidente ao Congresso para ser aprovado. Nesse mesmo ano ${ }^{63}$, por sugestão de Lourenço Filho, Capanema cria o Instituto Nacional de Pedagogia, incluindo-o no artigo 39 da Lei no 378, de 13 de janeiro de 1937, mas não o implementa. Sua implementação só se efetivou com o Decreto-Lei de 30 de julho de 1938, agora com o nome de INEP - Instituto Nacional de Estudos Pedagógicos.

No ano de 1938, pelo Decreto-Lei $\mathrm{n}^{\mathrm{o}}$ 1.006, de 30 de dezembro, foi ainda criada a Comissão Nacional do Livro Didático (CNLD), que estabelecia a primeira política de legislação para a produção, o controle e a circulação de obras didáticas.

A partir daí, a Reforma Capanema, com um total de seis reformas, definiu e implantou leis para gerir a educação em diversos setores, como por exemplo, a Lei Orgânica do Ensino Industrial em janeiro de 1942, a Lei Orgânica do Ensino Secundário em abril de 1942, a reformulação do ensino comercial em fevereiro de 1943. Até mesmo depois do período do Estado Novo, em 1946, Capanema ainda determinou três Leis Orgânicas (Ensino Primário, Normal e Ensino Agrícola), estabelecendo programas e diretrizes.

De acordo com alguns estudos (XAVIER, M., 1990; BRITO, S. ${ }^{64}$ ), a ênfase dada pela Reforma Capanema na questão nacional deve ser entendida com a consideração de que o cenário mundial da época favorecia o desenvolvimento do nacionalismo. Mesmo assim, é importante ressaltar que a Reforma Capanema preocupou-se em valorizar o ensino de línguas estrangeiras, recomendando a metodologia (Método Direto), assinalando seus objetivos práticos e de caráter instrumental e atribuindo a carga horária de trinta e cinco horas semanais (15\% do currículo) aos estudos de língua estrangeira. Vale mencionar que, dessa carga horária, as aulas de língua inglesa perfaziam o total de doze horas semanais. Constavam do currículo obrigatório do Ensino Secundário, além do inglês, o francês, com treze horas

63 Cf. SAVIANI, D. O INEP, o diagnóstico da educação brasileira e a RBEP. Disponível em: <http://rbep.inep.gov.br/index.php/RBEP/article/viewFile/2681/1825>. Acesso em: 15 fev. 2013.

${ }^{64}$ BRITO, S. Disponível em: 〈http://www.histedbr.fae.unicamp.br/navegando/artigos frames/artigo_101.html〉. Acesso em: 28 fev. 2011. 
semanais; o latim, com oito horas semanais no curso ginasial e o espanhol, com duas horas semanais no colegial. No curso Clássico, as línguas estrangeiras estudadas eram o latim e o grego $^{65}$.

Seria, então, ainda segundo as autoras, Xavier (1990) e Brito ${ }^{66}$, exagero afirmar que houve a construção de uma pedagogia autoritária, pois tais medidas não chegaram a se constituir em política de Estado e a organização da escola que foi criada não pode ser percebida como tendo gerado tal impacto na sociedade. Nas palavras de Brito ${ }^{67}$,

Estes projetos, marcados por um discurso preocupado com a construção da nacionalidade, com a valorização da brasilidade, pela afirmação da identidade nacional brasileira, — voltada esta última para a própria construção da identidade do homem trabalhador e para a delimitação do que seria nacional —, enfatizavam a dimensão estratégica da educação.

Portanto, podemos entender que, mesmo nesse cenário político autoritário, as políticas já não se faziam mais pelos meios soberanos, mas agiam como formas disciplinadoras, como estratégias para organizar o caos e atingir os objetivos estabelecidos. Ainda segundo Schwartzman, Bomeny e Costa ([1984] 2000, p. 218),

A reforma do ensino secundário de 1942 ficaria em síntese caracterizada pela intenção de consolidar a escola secundária como principal instituição educacional e, através dela, formar novas mentalidades, criar uma cultura nacional comum e disciplinar as gerações para garantir a continuidade da pátria. Através dela, também, esperava-se produzir uma nova elite para o país. Uma elite católica, masculina, de formação clássica e disciplina militar. A ela caberia a condução das massas e a ela estaria reservado o acesso ao ápice da pirâmide educacional.

Nesse sentido, a Reforma Capanema é um momento histórico importante em que observamos um modo de funcionamento do controle disciplinar.

No período que sucede o Estado Novo, conhecido como Nova República (1946-1964), a educação é marcada pela forte influência do cognitivismo piagetiano. A teoria psicogenética de Piaget (1896-1980), apesar de não propor uma teoria da aprendizagem, contribuiu (e ainda contribui), com seu método e rigor científico, ao campo da educação. Seu trabalho teve rápida

\footnotetext{
${ }^{65}$ De acordo com as informações do PGLA - Programa de Pós-Graduação em Linguística Aplicada da Universidade de Brasília: UnB - no texto intitulado Reforma Capanema: pico na oferta de línguas. Disponível em: 〈http://www.helb.org.br〉. Acesso em: 14 fev. 2013.

${ }^{66}$ BRITO, S. Disponível em: 〈http://www.histedbr.fae.unicamp.br/navegando/artigos frames/artigo 101.html>. Acesso em: 28 fev. 2011.

${ }^{67}$ Ibidem, p. 9.
} 
repercussão mundial, inclusive no Brasil $^{68}$. O estabelecimento dos diferentes estilos individuais de aprendizagem postulados por Jean Piaget influenciou, em maior ou menor grau, desde sua primeira visita ao Brasil em 1946, os contornos da educação no país, inclusive delineando os PCN - Parâmetros Curriculares Nacionais de $1998^{69}$.

A nova constituição de 1946 determinou o cumprimento obrigatório do ensino primário e a competência da União (estados, municípios e o distrito federal) para legislar sobre as diretrizes e bases da educação nacional. No mesmo ano, são baixados os decretos-lei que regulamentam os ensinos primário, normal e agrícola, ainda como parte da Reforma Capanema. A partir de então, são criados vários institutos, como o Serviço Nacional de Aprendizagem Comercial - SENAC, o Instituto Tecnológico da Aeronáutica - ITA (1947), e universidades, como a Universidade Federal de Pernambuco e a Pontifícia Universidade Católica de São Paulo (ambas em 1946), a Universidade Católica de Pernambuco (1951), a Universidade Mackenzie em São Paulo (1952), a Universidade Federal do Ceará (1954), a Pontifícia Universidade Católica de Campinas, a Universidade Federal da Paraíba (ambas em 1955) e a Universidade Federal do Pará (1957), entre outras.

Até 1960, a educação brasileira era centralizada e os órgãos municipais e estaduais seguiam o modelo estabelecido pelo governo federal através do MEC, que em 1953 se separara do Ministério da Saúde. Antes disso, em 1948, o projeto de Lei de Diretrizes e Bases para a Educação Nacional (LDB) é encaminhado ao Congresso Nacional. Em 1955, o Deputado Carlos Lacerda apresenta seu primeiro substitutivo a esse projeto; porém, é seu terceiro substitutivo, a Emenda Carlos Lacerda, que prevaleceu sobre o texto das Diretrizes e Bases da Educação Nacional, alterando substancialmente o vigor do projeto original ${ }^{70}$. Mesmo assim, apenas em 1961 foi promulgada a Lei 4.024, que regulamenta as Diretrizes e Bases da Educação Nacional, a primeira LDB promulgada, após dezesseis anos de discussão em torno da filosofia que lhe deveria caracterizar. As ideias do grupo de liberalistas, ligados aos partidos de centro e de direita, prevaleceram no texto da primeira LDB. O ensino religioso passou a ser facultativo e houve a diminuição do controle e centralização do MEC, permitindo maior autonomia aos municípios e estados ${ }^{71}$. Pela LDB de 1961, o oferecimento de línguas estrangeiras não era mais obrigatório, ficando a cargo dos

\footnotetext{
${ }^{68}$ Cf. CAETANO, L. M. A epistemologia genética de Jean Piaget. ImPrensa: Boletim Online do Instituto de Psicologia, 29/9/2010. Disponível em: $<$ http://www.ip.usp.br/portal/index.php?option=com content\&view=article\&id=1797:a-epistemologia-geneticade-jean-piaget\&catid=46:na-midia\&Itemid=97>. Acesso em: 12 fev. 2013.

${ }^{69} \mathrm{Cf} .<$ http://portal.mec.gov.br/seb/arquivos/pdf/rcnei_vol1.pdf>. Acesso em: 17 fev. 2013.

${ }^{70}$ Cf. <http://www.pedagogiaemfoco.pro.br/heb07.htm\#manif1 >. Acesso em: 6 mar. 2011.

${ }^{71}$ Cf. <http://portal.mec.gov.br/index.php?option=com content\&view=article\&id=2\&Itemid=171>. Acesso em: 05 mar. 2011.
} 
estados a sua inclusão no currículo dos segmentos que hoje conhecemos por Ensino Fundamental e Ensino Médio. Entretanto, desde a Segunda Guerra Mundial, o interesse, principalmente das populações urbanas brasileiras, pelo aprendizado da língua inglesa vinha aumentando devido à intensificação da dependência econômica e cultural do Brasil em relação aos Estados Unidos da América ${ }^{72}$.

Com a LDB de 1971, dez anos depois, as línguas estrangeiras permaneceram como disciplinas não obrigatórias e, com o sempre crescente interesse da população pelo conhecimento da língua inglesa, gerado por necessidades econômicas e culturais, houve um grande aumento na procura por cursos particulares em institutos de idiomas ou por aulas com professores particulares. Essa procura pode ter sido o resultado direto das principais propostas da LDB de 1971: a redução de um ano escolar, a necessidade de foco na habilitação profissional e a diminuição da carga horária de língua estrangeira para duas ou três horas semanais no currículo do Ensino Fundamental.

Para atender à necessidade de oferta de ensino profissionalizante, respeitando a redução de um ano escolar, muitas escolas ofereciam apenas uma aula semanal de língua estrangeira e outras nem ofereciam. Essa redução, além do interesse pela língua inglesa, acabou por fazer com que as escolas que ofereciam uma língua estrangeira optassem pelo inglês. Ainda visando à formação profissional, o método áudio-lingual foi adotado para o ensino de inglês. Além de elitizar o ensino de línguas estrangeiras, o não oferecimento de ensino de línguas com qualidade na escola pública pode ter colaborado para a naturalização do dizer de que, em escolas regulares, não é possível aprender inglês, ou outra língua estrangeira.

A Resolução 58/76 de 22 de dezembro de 1976 do Conselho Federal de Educação (CFE-MEC) resgata parcialmente o ensino de línguas estrangeiras na escola pública. Essa resolução estabelece a obrigatoriedade do ensino de língua estrangeira moderna no $2^{\circ}$ Grau (Ensino Médio) e recomenda sua inclusão no $1^{\circ} \mathrm{Grau}$, especialmente a partir do quinto ano, às escolas que apresentem condições para implementarem essa inclusão ${ }^{73}$.

Alguns anos depois, em 1996, com a LDB atual, a educação brasileira passou por nova reforma. Entre as mudanças, destacaram-se a inclusão da educação infantil, como segmento oficial da educação, e a ênfase na educação básica, como, por exemplo, a

\footnotetext{
${ }^{72} \mathrm{Cf} . \quad\left\langle\right.$ http://www.helb.org.br/index.php?option=com $\_$content\&view=article\&id=32:ldb-de1961\&catid=1035:1961\&Itemid=2>. Acesso em: 14 fev. 2013.

${ }^{73}$ Disponível em:

<http://www.histedbr.fae.unicamp.br/navegando/fontes escritas/7 Gov_Militar/resolu\%E7\%E3o\%20n.581976\%20altera\%20dispositivos>. Acesso em: 22 nov. 2013.
} 
preocupação com a formação do profissional da escola básica. Em relação às línguas estrangeiras, a LDB de 1996 estabeleceu a obrigatoriedade desse ensino a partir do sexto ano (antiga quinta série) do Ensino Fundamental e, para o Ensino Médio, uma segunda língua estrangeira deveria ser oferecida como optativa, respeitando as possibilidades e condições de cada escola.

Apesar da não obrigatoriedade de escolha pelo ensino de língua inglesa, muitas vezes o inglês era a única língua oferecida. Com a Lei $\mathrm{n}^{\circ} 11.161$, de 05 de agosto de 2005, a oferta do ensino de língua espanhola passa a ser obrigatória ${ }^{74}$ a partir de cinco anos decorridos de sua promulgação ${ }^{75}$. Houve, na época, muitas dúvidas em relação à execução dessa lei. Hoje, sabemos que as escolas devem oferecer duas línguas estrangeiras modernas no Ensino Médio, sendo a oferta do ensino de língua espanhola obrigatória para esse segmento e facultativo para os últimos anos do Ensino Fundamental. Assim, no Ensino Médio, o ensino de língua espanhola é de oferta obrigatória para a escola e de matrícula facultativa para os alunos.

Não há, na LDB de 1996, a indicação de um método para o ensino de línguas estrangeiras. Em 1998, os Parâmetros Curriculares Nacionais (PCN) começam a ser publicados, com o objetivo de orientar os professores sobre os procedimentos de acordo com os preceitos previstos na LDB de 1996. Na primeira versão, em 1998, os $\mathrm{PCN}^{76}$ têm como foco o Ensino Fundamental ( $5^{\mathrm{a}}$ a $8^{\mathrm{a}}$ séries) e sugerem a abordagem sociointeracional, com ênfase na leitura e associada aos temas transversais. A partir daí, outras abordagens são também sugeridas. Os PCN de $2000^{77}$, para o Ensino Médio, incluem o ensino de língua estrangeira na grande área delimitada como Linguagens, Códigos e suas Tecnologias e privilegiam a abordagem comunicativa, atribuindo à língua a função de veículo de comunicação e de acesso ao conhecimento. O oferecimento do ensino de uma segunda língua estrangeira é fortemente incentivado nesses PCN, que orientam as escolas a vincularem a escolha da segunda língua às necessidades da comunidade em que se inserem. Posteriormente, em 2002, com o subtítulo de Orientações Educacionais Complementares aos Parâmetros Curriculares Nacionais, são publicados os $\mathrm{PCN}+$ para o Ensino Médio. Os $\mathrm{PCN}+{ }^{78}$ acrescentam orientações práticas sobre a contextualização dos conteúdos e a articulação

\footnotetext{
74 Sobre as dúvidas relativas à implementação dessa lei, veja < http://portal.mec.gov.br/cne/arquivos/pdf/2007/pceb018 07.pdf>. Acesso em:14 fev. 2013.

Cf. $\quad$ http://www.helb.org.br/index.php?option=com content\&view=article\&id=69:publica-da-lei-dediretrizes-e-bases-no-9394\&catid=1041:1996\&Itemid=2>. Acesso em: 14 fev. 2013.

${ }^{76}$ Disponível em: < http://portal.mec.gov.br/seb/arquivos/pdf/pcn_estrangeira.pdf>. Acesso em: 22 nov. 2013.

${ }^{77}$ Disponível em: $<$ http://portal.mec.gov.br/seb/arquivos/pdf/14_24.pdf $>$. Acesso em: 22 nov. 2013.

${ }^{78}$ Disponível em: < http://portal.mec.gov.br/seb/arquivos/pdf/linguagens02.pdf>. Acesso em: 22 nov. 2013.
} 
desses às competências (inquirir, compreender, executar, revisar, avaliar, $\operatorname{agregar}^{79}$ ) e habilidades (analisar, comparar, associar, identificar, reconhecer, selecionar ${ }^{80}$ ) e ressaltam a importância da formação continuada dos professores. Nota-se que os PCN+ (2002, p. 94) estabelecem como objetivos do ensino de língua estrangeira a preparação do aluno para os "desafios" na "vida escolar, no mundo social e do trabalho", através da aprendizagem das competências e habilidades citadas acima e também das quatro habilidades linguísticas (ler, ouvir, falar e escrever $)^{81}$.

Também o PNLD 2011considera a abordagem comunicativa e a prática das quatro habilidades linguísticas. De início, os critérios específicos eliminatórios para Língua Estrangeira Moderna estabelecidos no Edital de Convocação ${ }^{82}$ do PNLD 2011 informam que as coleções aprovadas devem entre outros critérios,

- propiciar condições para o desenvolvimento integrado das habilidades de compreensão e produção oral, bem como de compreensão e produção escrita;

- contribuir para o desenvolvimento da competência comunicativa do aluno, por meio de produção e recepção de textos orais e escritos de vários gêneros;

Em maio de 2011, um Parecer ${ }^{83}$ do Conselho Nacional de Educação (CNE) e da Câmara de Educação Básica (CEB) retrata o Ensino Médio na escola pública brasileira, afirmando que "sua estrutura, seus conteúdos, bem como suas condições atuais, estão longe de atender às necessidades dos estudantes, tanto nos aspectos da formação para a cidadania como para o mundo do trabalho". A partir da homologação desse Parecer CEB/CNE no 5/2011, publicado no Diário Oficial da União em 24 de janeiro de 2011, outro documento é elaborado: a Resolução n. 2 de 30 de janeiro de 2011, que define as Diretrizes Curriculares Nacionais (DCN) para o Ensino Médio no país. Esse documento ressalta o papel do projeto político-pedagógico $(\mathrm{PPP})$ da escola em relação à organização curricular, que deve ser estruturada pela escola com base na LDB de 1996, objetivando a articulação entre o trabalho, a ciência, a tecnologia e a cultura. Há, também, a ênfase na necessidade de a organização

\footnotetext{
${ }^{79}$ Cf. p. 115 dos PCN+. Disponível em: 〈http://portal.mec.gov.br/seb/arquivos/pdf/linguagens02.pdf〉. Acesso em: 22 nov. 2013.

${ }^{80}$ Idem, p. 118.

${ }^{81}$ Idem . p. 116.

${ }^{82}$ O documento Edital de Convocação para Inscrição no Processo de Avaliação e Seleção de Coleçães Didáticas para o Programa Nacional Do Livro Didático é publicado e disponibilizado às editoras pelo Ministério da Educação (MEC), Fundo Nacional de Desenvolvimento da Educação (FNDE) e pela Secretaria de Educação Básica (SEB), com o objetivo de instruir as editoras sobre as normas de elaboração das coleções que serão inscritas no programa e submetidas à avaliação.

${ }^{83}$ Parecer CEB/CNE nº 5/2011, p. 1. Disponível em: < http://portal.mec.gov.br $>$. Acesso em: 23 nov. 2013.
} 
curricular atentar à formação integral do aluno, visando a indissociabilidade entre a educação e a prática social.

Através desse breve percurso, podemos dizer que desde a Reforma Capanema até a LDB atual, considerando a drástica diminuição de carga horária atribuída para o ensino de inglês na escola pública (de doze horas para duas horas semanais) e o abandono do ensino de outras línguas (francês, alemão etc.), podemos considerar que houve uma crescente desvalorização do ensino de línguas estrangeiras na escola pública brasileira.

Observamos, a seguir, o caminho do LDI em relação a esse percurso de ensino que descrevemos aqui.

\section{$1.3 \mathrm{O}$ livro didático de inglês no Brasil}

Ao transmigrar para o Brasil, a Família Real trouxe consigo prensas e tipos móveis de uso do governo em Portugal, favorecendo a instalação da primeira casa impressora no Brasil, a Impressão Régia ${ }^{84}$. Por decreto do Príncipe Regente D. João, a Impressão Régia foi criada em 13 de maio de 1808, para que fossem impressos os documentos oficiais, folhetos para a divulgação de eventos e festas da corte e permitindo, também, a publicação de diversas obras que tivessem sido aprovadas pela censura oficial da Imprensa Real.

Antes da vinda da Família Real, a publicação em solo brasileiro era proibida e existia apenas clandestinamente. Essa proibição existia como forma de controle sobre as ideias que circulavam na colônia e que pudessem ser contrárias àquelas aceitas por Portugal $^{85}$. Os materiais usados no Brasil eram importados da Europa. Há registros de livros para o aprendizado da língua inglesa para falantes de português desde meados do século XVIII ${ }^{86}$, por exemplo: a Grammatica anglo-lusitanica e Lusitano-anglica, segunda edição, assinada por Jacob de Castro e produzida em Londres em 1751 para o mercado português, usada mais tarde no Brasil. Castro, "mestre e traductor de ambas as línguas" ${ }^{\text {" }}$ publicou vários livros nas duas décadas seguintes. Entre esses livros, assinou, em 1777, dois títulos: Grammatica lusitanoanglica, ou portugueza e ingleza, a qual serve para instruir os portuguezes no idioma inglez (com 269 páginas) e Grammatica da lingua ingleza, etc., segunda edição, ambas produzidas em Londres para o leitor português. Antes dessas publicações, havia maior

\footnotetext{
$84 \quad$ Cf. $<$ http://www.cultura.gov.br/site/2008/04/22/200-anos-da-impressao-regia/; http://portal.in.gov.br/imprensa1/a-imprensa-nacional/>. Acesso em: 09 mar. 2011.

${ }^{85} \mathrm{Cf}$. 〈http://educarbrasil.org.br/Portal.Base/Web/VerContenido.aspx?ID=206628 >. Acesso em: 10 mar. 2011.

${ }^{86} \mathrm{Cf}$. 〈http://ler.letras.up.pt/uploads/ficheiros/artigo7581.pdf>. Acesso em: 10 mar. 2011.

${ }^{87}$ Idem.
} 
abundância de obras voltadas ao ensino de português aos ingleses devido aos interesses comerciais da época.

No Brasil, principalmente de acordo com o programa de ensino do Colégio Pedro II, como pesquisado por Oliveira ${ }^{88}$ (2006), os livros didáticos ou compêndios, como eram chamados, apresentavam quatro gêneros: gramáticas, seletas (coletâneas de excertos de outras obras, como spelling ou class books), diálogos modelos e cursos de literatura (com excertos de obras literárias). Oliveira aponta os seguintes compêndios como os mais usados no Brasil até o século XIX:

1. Grammatica Anglo-lusitanica \& Lusitano-anglica ou Grammatica nova, ingleza e portugueza, e portugueza e ingleza; dividida em duas partes. Como dissemos acima, foi publicada em Londres e escrita por Jacob de Castro em 1751, tendo sua terceira edição em 1759.

2. Grammatica Ingleza ordenada em portuguez. Foi escrita por Carlos Bernardo da Silva Teles de Menezes e publicada em Portugal em 1762.

3. Compendio da Grammatica ingleza e portuguesa para uso da mocidade adiantada nas primeiras letras, datado de 1820 e assinado por Manoel José de Freitas.

4. Arte Ingleza offerecida ao illustrissimo Senhor Visconde de Cayru, de 1827, escrito pelo Padre Guilherme Paulo Tilbury.

5. Primeiras Regras da Lingua ingleza, 1841.

6. Estações. Escrito por James Thomson em 1855.

7. Compendio da Grammatica Ingleza. Escrito por Raphael Galanti em 1862.

8. Grammatica pratica da Lingua Ingleza. Escrita por Fillipe Maria da Motta d'Azevedo Corrêa em 1863.

9. Selecta Anglo-americana, 1870.

10. Collection of Classical Extracts, 1870.

11. Systema Pratico e Theorico para Aprender a ler, escrever e fallar com toda a perfeição a Lingua Ingleza em 50 lições conforme o methodo de Ollendorff, assinado por Nicoláo James Tolstadius, 1871.

\footnotetext{
${ }^{88}$ OLIVEIRA, L., em sua tese de doutorado de 2006, A instituição do Ensino das Línguas Vivas no Brasil: o caso da Língua Inglesa (1809-1890), informa detalhes sobre o currículo e método do Colégio Pedro II, além de fornecer algumas informações sobre o Colégio Estadual do Atheneu Norte-Riograndense, o mais antigo dos colégios em atividade no Brasil. $\langle\underline{\text { http://www.sapientia.pucsp.br/tde busca/arquivo.php?codArquivo=2255 }\rangle . ~ A c e s s o ~ e m: ~} 10$ mar. 2011.
} 
12. Novo Methodo Pratico e Facil para se aprender a lingua inglesa segundo os princípios de F. Ahn, adaptado a lingua portuguesa por Pacheco Junior, de autoria atribuída a Graeser ${ }^{89}, 1873$.

O compêndio Grammatica pratica da Lingua Ingleza ${ }^{90}$, de autoria de Corrêa, é comumente apontado como sendo o primeiro livro didático de língua inglesa usado no Brasil $^{91}$. Certamente, esse foi o compêndio mais publicado nesse período e, em 1927, atinge sua vigésima primeira edição ${ }^{92}$. Outros títulos tiveram ainda muitas edições, como por exemplo, o Compendio da Grammatica Ingleza de Galanti, que atinge sua quinta edição ${ }^{93}$ em 1913. Há, ainda, outro livro que, apesar de não constar da lista apresentada acima, merece atenção. A Gramática da língua inglesa de Frederico Fitzgerald teve sua primeira publicação em Porto Alegre (RS) em 1880 e em 1940 atingiu sua $34^{\mathrm{a}}$ edição ${ }^{94}$. Na mesma década $^{95}$, Fitzgerald publicou outro livro, intitulado Gramatica Teorica e Pratica da Lingua Inglesa, pela editora Livraria Selbach de J. R. da Fonseca, também em Porto Alegre.

Já nesses primeiros livros, como na Grammatica Anglo-lusitanica \& Lusitanoanglica, é possível observar algumas diferenças em relação aos livros de grego e de latim que tinham como base textos literários para tradução. Isso porque, apesar de seu foco principal ser a tradução e a gramática, a Grammatica Anglo-lusitanica \& Lusitano-anglica, por exemplo, segundo Oliveira (2006), valorizava aspectos práticos e utilitários do uso do inglês. Para isso, fornecia exemplos através de textos de documentos comerciais e oficiais (letras de câmbio, apólices, declarações, recibos etc.), propunha elementos para os estudos da fonética (ao apresentar os sons das letras do alfabeto) e da prosódia (ao marcar a entonação das palavras nas sentenças) além de incluir, ao final, "pequenos diálogos familiares [...] 'para expressar acçois mais ordinárias"” (OLIVEIRA, L., 2006, p. 66).

A partir daí, no final do século XIX e início do século XX, houve um notável crescimento na produção e na circulação de livros didáticos. Aliás, esse período é considerado

\footnotetext{
${ }^{89}$ Disponível em:< http://ler.letras.up.pt/uploads/ficheiros/artigo7581.pdf>. Acesso em: 23 nov. 2013.

${ }^{90}$ Para a descrição completa dessa obra, veja OLIVEIRA, L. (2006), conforme dados na nota anterior.

${ }^{91}$ Inúmeros estudos sobre o livro didático de inglês apontam esse compêndio de Corrêa como marco inicial no Brasil. Veja, também, as informações no site do Livres - Faculdade de Educação da USP, que observa o período de 1810 a 2005. Disponível em: 〈http://www2.fe.usp.br/estrutura/livres/index.htm>. Acesso em: 04 dez. 2010.

${ }^{92}$ Há um exemplar da oitava edição desse compêndio, datado de 1890, no acervo Paulo Bourroul da Biblioteca do Livro Didático do Centro de Memória da Educação: CME-FEUSP.

${ }^{93}$ Há também um exemplar dessa quinta edição (1913) na Biblioteca do Livro Didático, CME da FEUSP.

${ }^{94}$ Cf. PAIVA, V., 2009.

95 O site do Livres informa a década de 1880; porém, não é possível determinar o ano exato da primeira publicação. Cf. 〈http://www2.fe.usp.br/estrutura/livres/index.htm>. Acesso em: 20 fev. 2013.
} 
por Circe Bittencourt (2004, p. 479) como o período inicial da produção nacional de livros didáticos. À página 480, Bittencourt esclarece,

\begin{abstract}
Um primeiro grupo iniciou sua produção a partir da chegada da família real portuguesa no Brasil, e suas obras foram produzidas pela Impressão Régia, mas podemos identificar uma primeira 'geração' a partir de 1827, autores preocupados com a organização dos cursos secundários e superiores, apenas esboçando algumas contribuições para o ensino de 'primeiras letras'. Uma segunda 'geração' começou a se delinear em torno dos anos 1880 , quando as transformações da política liberal e o tema do nacionalismo se impuseram, gerando discussões sobre a necessidade da disseminação do saber escolar para outros setores da sociedade, ampliando e reformulando o conceito de 'cidadão brasileiro', criando-se uma literatura que, sem abandonar o secundário, dedicaram-se à constituição do saber da escola elementar. [sic]
\end{abstract}

Alguns pesquisadores ${ }^{96}$ mencionam, para a década de 1930, os seguintes livros: Novíssimo Methodo da Língua Inglesa, de 1931, da Livraria Francisco Alves e de autoria não identificada; Lingua Ingleza Primeiro Methodo, de 1933, da FTD e Livraria Paulo de Azevedo \& C., também sem identificação de autoria; English Easily Spoken, de 1936, Edições Melhoramentos, de autoria de Neif Antonio Alem; e King's English, de 1939, Cia. Ed. Nacional, de autoria de Harold Howard Binns, elaborado para o segundo ano do curso ginasial. Todos esses livros enfocavam a gramática e a tradução.

Tendo sua primeira edição em 1936, o livro The English gymnasial grammar foi adotado em muitos estados brasileiros, o que, segundo Paiva (2009, p. 23), "demonstra sua penetração em quase todo o território nacional”. Apesar de ter seu foco ainda fortemente sobre a gramática e a tradução, esse livro já mostrava maior preocupação com a oralidade; pois, como afirma Paiva (2009, p. 24), o livro inovava ao apresentar transcrições fonéticas; porém, a língua ainda era vista como um conjunto de regras gramaticais.

O livro An English method de Pe. Julio Albino Pinheiro foi publicado em Portugal em 1930 e adotado no Brasil pelo Colégio Pedro II em 1939 ${ }^{97}$. Paiva (2009, p. 24) informa que "apesar de o foco predominante ainda serem nas estruturas gramaticais, também inclui a língua como comunicação e como veículo de práticas sociais diversas, da conversa à manifestação estética" [sic]. As inovações desse livro compreendem: exercícios de repetição por substituição (drills), interações conversacionais, material de áudio (lições e sons dos símbolos fonéticos gravados em disco de gramofone) e ausência de exercícios de tradução.

\footnotetext{
${ }^{96}$ Veja PICCIN, I. M.; SILVA, M. A. C. M. B. O ensino de pronúncia em livros brasileiros para o ensino de inglês: perspectiva histórica. Disponível em: <revistas.pucsp.br/index.php/intercambio/article/download/.../2630>. Acesso em: 18 fev. 2013.

${ }^{97}$ PAIVA, V., (2009) informa a data de adoção como sendo 1939, constante da capa de um exemplar. Não há informações sobre outras datas de adoção desse livro.
} 
No fim da década de 40, os livros que consideravam a língua falada começaram a buscar seu lugar no mercado editorial ao lado daqueles com foco na gramática e na tradução. Ao recomendar o Método Direto (já em vigor na Europa desde o início do século) como a metodologia ideal e estimular um ensino de línguas marcado por objetivos práticos e de caráter instrumental, a Reforma Capanema proveu o ambiente profícuo para a produção de materiais técnicos. Relacionados a essa década, podemos encontrar ${ }^{98}$ livros e dicionários para usos específicos, como o Dicionário de têrmos técnicos inglês-português de H. A. Buzzoni e Souza Lago, publicado pela Livraria Editora Paulicéia em 1943; o Dicionário inglêsportuguês de têrmos militares de Homero de Castro Jobim, publicado em Porto Alegre pela Livraria do Globo em 1944; o Dicionário aerotécnico inglês-português, compilado e organizado por Carlos Nayfeld e publicado pela Cia. Editora Leitura em 1945; o Novo dicionário técnico inglês-português: novo dicionario técnico e químico de Adalberto Aumuller, pela Livraria Kosmos, E. Eichner \& Cia., Ltda., em 1946; o Dicionário médico inglês-português baseado no dicionário médico de Gould de Eurico Fernandes para a Editora Gertum Carneiro (RJ), publicado em 1947; o Pequeno vocabulário português-inglês de terminologia agrícola de Guerra Filho publicado também em 1947, logo após o estabelecimento da Lei Orgânica do Ensino Agrícola. No ano seguinte, é publicado o livro Ingles tal qual se fala no presente, sem auxilio de professor de Oliveira Malta pela editora Cia Brasil Ed. em 1948, justamente na época em que o Estado apostava no Método Direto, que promovia a comunicação na língua alvo por meio de associações e sem interferência da língua materna.

$\mathrm{Na}$ escola regular, os livros de João Fonseca, entre eles o Spoken English e depois o New spoken English, foram muito utilizados no curso ginasial a partir de 1950 no Brasil, segundo Paiva (2009). Porém, não há outras informações disponíveis sobre os livros de inglês adotados em escolas públicas brasileiras entre as décadas de 40 e 60. Sobre a escassez de livros didáticos como materiais de pesquisa, $\operatorname{PAIVA}^{99}(\mathrm{~s} / \mathrm{d})$ informa na primeira nota de sua publicação Ensino de língua inglesa: antecipando uma pedagogia pós-moderna: "As bibliotecas, geralmente, descartam esse tipo de material, inviabilizando o registro histórico da evolução do gênero".

A década de 70 foi marcada pelo surgimento de materiais audiovisuais. Esse tipo de material propunha o aprendizado pela exposição do aluno a gravações de áudio associadas a imagens. O contato do aluno com o texto escrito era adiado até que ele mostrasse que havia

\footnotetext{
${ }^{98}$ Cf. $<$ http://biblioteca.fflch.usp.br/dedalus $>$. Acesso em: 20 fev. 2013.

${ }^{99}$ Disponível em: <http://www.veramenezes.com/solange1.pdf $>$. Acesso em: 21 fev. 2013.
} 
entendido e poderia reproduzir as falas com pronúncia e entonação corretas. Para isso, os livros apresentavam figuras sem textos ou os textos deveriam ser cobertos pelo aluno, com uma máscara própria, uma folha de papel ou outro material.

No Brasil, a metodologia audiolingual, o método direto e a metodologia de gramática e tradução coexistiam na década de $70^{100}$. Paiva (2009) relaciona a essa década os livros de Solange Ribeiro de Oliveira: Structural English with audio-visual aids, adotado em todo o país, Trip to the moon e The blue earth; além de incluir um livro produzido por ela mesma e Júlio Pinto. Acreditamos que esse livro, cujo título não é informado por Paiva (2009), seja o Let's go, da editora do Brasil. Outros autores brasileiros ${ }^{101}$ que produziram livros didáticos nessa época foram: João Fonseca, Vicente Andrade, com o seu livro Audio-Oral English e Mary Tavares. Nessa mesma década, surgem os primeiros livros de Amadeu Marques, que até hoje tem larga produção de livros didáticos, de leitura, de atividades lúdicas e dicionários para o ensino de inglês nos segmentos da escola básica. Aliás, uma das coleções aprovadas para o PNLD 2011, Links, é de autoria de Amadeu Marques em parceria com Denise Machado dos Santos pela editora Ática.

Os anos da década de 1980 foram marcados pela tendência de se prover mais recursos didáticos para o ensino. A partir daí, o livro didático passou a compor um pacote que geralmente oferece o livro de exercícios, o livro do professor, materiais de áudio (no princípio fitas e depois CDs), materiais de vídeo (fitas VHS e depois DVDs) e, muitas vezes, livros paradidáticos, de pronúncia e dados de acesso para sites que fornecem exercícios extras e orientações ao professor. Sobre isso, Paiva (2009) cita os exemplos dos livros importados Streamline (1978, ed. Oxford) e Interchange (ed. Cambridge) e nos lembra que alguns títulos foram relançados, oferencendo esses recursos adicionais, como o Headway, publicado originalmente em 1986 pela editora Oxford ${ }^{102}$; English file, publicado pela primeira vez em 1996 também pela editora Oxford e o Interchange (ed. Cambridge).

No Brasil, a década de 80 viu surgir muitos autores de livros didáticos de inglês especialmente voltados à escola pública brasileira. Com muitos livros vendidos em todo o país desde o início de 1980 até hoje, estão Eduardo Amos, geralmente em parceria com Elisabeth Prescher e Ernesto Pasqualin; Lafayette Megale; Vera Zahar; Dirce Guedes Azevedo e Ayrton Azevedo Gomes, entre outros.

\footnotetext{
100 Cf. PAIVA, V., (s/d). No começo era o caos: minha colcha de retalhos. Disponível em: $\langle$ www.veramenezes.com/pesq_vera.htm>. Acesso em: 18 fev. 2013.

101 Veja nota acima.

${ }^{102}$ As datas das publicações originais da editora Oxford nos foram fornecidas via correspondência eletrônica em 25 fev. 2013.
} 
Apesar do encarecimento dos livros didáticos importados a partir de 1930 (CARMAGNANI, A., 1999, p. 46), a chegada de institutos de cursos livres com participação estrangeira nessa mesma década, como assinalamos acima, contribuiu para a manutenção do fluxo de importação de materiais didáticos. Por outro lado, esse mesmo encarecimento levou ao crescimento da produção nacional de livros didáticos. Até hoje, o livro didático importado continua a competir em alguns segmentos do mercado educacional com o livro nacional. $\mathrm{O}$ material nacional, de modo geral, tem mantido, ao longo dos anos, características próprias ao observar o contexto em que se insere, como aponta Bittencourt (2004, p. 489) ao analisar os primeiros livros didáticos nacionais,

\begin{abstract}
Mesmo que a forma se assemelhasse aos livros estrangeiros, os textos escolares expressaram uma produção própria que buscava atender as condições de trabalho dos professores das escolas públicas que se espalhavam pelo país. Procuravam suprir a ausência de formação dos docentes, em sua grande maioria leigos e autodidatas. [sic]
\end{abstract}

Vemos, portanto, que a função de contribuir com a formação docente, suprindo deficiências, já era uma atribuição do livro didático desde seu início no Brasil, assim como é até hoje. Historicamente marcado, o papel duplo do livro didático de ensinar tanto ao aluno como ao professor apaga a grande diferença entre esses dois tipos de ensino e também a diferença entre ensinar e aprender. Aliás, é comum encontrarmos o termo ensinoaprendizagem, com hífen, e até a expressão no singular "o processo de ensino-aprendizagem", como se fosse apenas um processo unilateral e infalível de causa e consequência em que alguém ensina e outro aprende. A presença do manual do professor em páginas opostas àquelas dos alunos ou mesmo em fascículo separado procura marcar a diferença espacialmente, disponibilizando em lugares diferentes aquilo que pertence ao aluno e o que pertence ao professor; ou ainda, aquilo que o aluno deve saber e o que o professor deve saber. Ainda no texto do Edital de Convocação ${ }^{103}$ do PNLD 2011, a mesma função de complementar a formação do professor é atribuída ao manual do professor, parte integrante do livro didático. Diz o Edital:

O Manual do Professor deve visar, antes de mais nada, a orientar os docentes para um uso adequado da coleção, constituindo-se, ainda, num instrumento de complementação didático-pedagógica e atualização para o docente. Nesse sentido, o Manual deve organizar-se de modo a propiciar ao docente uma efetiva reflexão sobre sua prática. Deve, ainda, colaborar para que $\underline{\mathrm{o}}$

\footnotetext{
${ }^{103}$ Veja também adiante, no item 5.1.1, a análise de outros dizeres do Edital de Convocação.
} 
processo de ensino-aprendizagem acompanhe avanços recentes, tanto no campo de conhecimento do componente curricular da coleção, quanto no da pedagogia e da didática em geral.

Ao atribuir ao manual do professor a incumbência de ser um "instrumento de complementação didático-pedagógica e atualização para o docente", os dizeres do Edital no excerto acima não apenas representam o professor como didática e pedagogicamente incompleto e desatualizado, mas delegam ao manual a tarefa de suprir essas deficiências e a fragilidade teórica do professor. Porém, a formação do professor não pode ser complementada, sem prejuízos, pelos conteúdos das páginas do livro didático que lhe são reservadas. Não há como realizar ou complementar uma formação profissional num espaço unilateral, longe do debate, da discussão e da pesquisa. Sobre isso, Dionísio ${ }^{104}$ (2008) é ainda mais enfática:

É preciso reforçar a tese de que a formação do professor é tarefa da instituição de ensino, quer seja nos cursos de Magistério quer seja nos cursos universitários. Deve ser, pois, com base nas orientações recebidas nessas instituições que o professor poderá saber o que fazer com o livro ou com os livros didáticos em suas aulas. O professor deveria saber o porquê dos conteúdos selecionados e as implicações das estratégias utilizadas nos livros didáticos. Os autores de livros didáticos costumam apresentar um Manual do professor, em que esclarecem sobre as correntes teóricas em que fundam suas obras, mas nem sempre há uma correlação entre tais teorias e as atividades propostas no livro do aluno. Algumas vezes, parece haver uma estratégia de marketing e não uma orientação teórico-metodológica.

Se de todo necessário, o manual do professor poderia apresentar sugestões pontuais em relação a algumas atividades, levando em consideração o saber profissional e a capacitação técnica do profissional que poderá vir a consultá-lo. Essa medida “de complementação didático-pedagógica e atualização para o docente" parece reconhecer, mas também generalizar, a precariedade da formação do profissional de língua estrangeira, procurando tamponar $^{105}$ a falta com que esse professor tem de lidar em seu dia a dia. De todo o modo, antes de tentar suprir deficiências, há de se melhorar a própria formação do professor e as condições envolvidas na sua atuação profissional. Munakata ${ }^{106}$ (2008) também argumenta

\footnotetext{
${ }^{104}$ Cf. DIONÍSIO, A. P. (2008, p. 82-88), Livros didáticos de Português formam professores? In: Congresso Brasileiro de Qualidade na Educação. Simpósio 6: O livro didático e a formação de professores. Publicado online em 01 jan. 2008. Disponível em: 〈http://portal.mec.gov.br/seb/arquivos/pdf/vollb.pdf>. Acesso em: 19 mar. 2013.

${ }^{105}$ No sentido psicanalítico do termo, vedar o lugar da falta, sem contudo saná-la.

${ }^{106}$ MUNAKATA, K. (2008, p. 89-94), Livro didático e formação do professor são incompatíveis? In: Congresso Brasileiro de Qualidade na Educação. Simpósio 6: O livro didático e a formação de professores. Publicado
} 
a favor do investimento na formação do professor como condição para a escolha do livro didático. Disse o autor:

Não que a formação esteja às mil maravilhas; ao contrário: é com muita apreensão que se assiste hoje ao incentivo à proliferação desenfreada de cursos improvisados de formação docente, muitos de curta duração, apenas para fazer cumprir estatisticamente o preceito da nova Lei de Diretrizes e Bases da Educação Nacional, que exige formação superior de todos os docentes em todos os níveis de ensino. Não é assim que os professores terão oportunidade de discutir as possibilidades de uso - e, portanto, de escolha dos livros didáticos. No máximo haverá tentativas de doutrinação dos professores, pelas quais se procurará "ensinar" como eles não sabem escolher livros e que por isso devem seguir as orientações dos avaliadores do PNLD.

Essas observações nos levam a pensar na necessidade de realizarmos mais pesquisas relacionadas ao LDI, tanto as que o tenham como objeto como aquelas que se dedicam a observar os modos de funcionamento do LDI em nossa sociedade. Traremos, abaixo, um breve olhar sobre as pesquisas relacionadas ao LDI nos últimos anos no Brasil.

\subsection{Estudos do discurso sobre o livro didático de inglês no Brasil}

Sabemos ${ }^{107}$ que há muitos trabalhos acadêmicos sobre o livro didático de inglês que já foram ou estão sendo desenvolvidos por pesquisadores brasileiros. Porém, esses trabalhos não representam ainda um número suficiente se considerarmos o volume de publicações e a ampla utilização desse material didático para o ensino de inglês no Brasil. Além disso, há ainda um número bem mais reduzido de pesquisas que tomam como objeto esses trabalhos sobre o livro didático de inglês no Brasil.

As pesquisas que tratam do livro didático de inglês analisam, entre outros, aspectos linguísticos, didático-pedagógicos, midiáticos, políticos, históricos, sociais e ideológicos - se é que podemos desmembrar esses itens individualmente em uma lista - que apreendem das páginas do livro didático de acordo com a sua interpretação das representações e a partir do seu viés teórico. Por outro lado, as pesquisas que estudam o discurso sobre o LDI dedicam-se a interpretar, também através de seu viés teórico, o funcionamento das representações desses mesmos aspectos (linguísticos, didático-pedagógicos etc.) conforme são percebidos por aqueles que falam do livro didático.

online em 01 jan. 2008. Disponível em: 〈http://portal.mec.gov.br/seb/arquivos/pdf/vol1b.pdf〉. Acesso em: 19 mar. 2013.

${ }^{107}$ Cf. APÊNDICE: Levantamento sobre trabalhos na área - conjunto da produção. 
Para falarmos com alguma propriedade sobre a produção e a circulação de pesquisas que estudam o discurso sobre o LDI, buscamos informações sobre trabalhos publicados nos últimos anos, de 2007 a 2013, em livros, dissertações, teses e artigos em sites de pesquisa acadêmica, de universidades e de grupos de estudos linguísticos de universidades brasileiras.

A grande maioria dos trabalhos encontrados tem o LDI como objeto e não analisa exatamente o discurso sobre o LDI. Nossa primeira dificuldade nessa busca foi a separação dos trabalhos que tomam o LDI como objeto daqueles que têm o discurso sobre o LDI como objeto. Um desses trabalhos é o artigo intitulado $O$ que os alunos pensam sobre o livro didático de inglês?. Apesar do título, o enfoque geral do artigo recai mais fortemente sobre o discurso do LDI e não exatamente sobre o LDI. Mesmo assim, há a investigação das opiniões dos alunos em três itens da pesquisa. As respostas dos alunos a um questionário sobre o LDI são calculadas com porcentagens para compor os resultados. Portanto, as opiniões dos alunos sobre o LDI são tomadas como transparentes e computadas para compor um quadro que determina se o LDI é ou não um material que agrada aos alunos.

Segundo os dados dos III Simpósio sobre o Livro Didático de Língua Materna e Estrangeira (SILID) / II Simpósio sobre Materiais e Recursos Didáticos (SIMAR) ${ }^{108}$, promovidos em julho de 2010, cinquenta e três pesquisas que têm o livro didático de língua estrangeira como referência foram realizadas entre 2004 e 2008. Entre essas pesquisas não encontramos trabalhos dedicados à análise do discurso sobre o livro didático de inglês. Também os trabalhos apresentados nesse evento de 2010 e em sua edição de 2013 têm, em geral, o LDI como objeto de análise. Alguns desses trabalhos ${ }^{109}$ tratam dos dizeres de professores e de alunos sobre o LDI; porém, vemos ainda alguma distância em relação ao nosso estudo. Isto é, nas pesquisas apresentadas nesses eventos, as análises seguem linhas teóricas diferentes da nossa e, portanto, trabalham com diferentes conceitos. Além disso, os dizeres são analisados em relação à prática pedagógica, com o objetivo de observar (in)congruências com a teoria e apontar caminhos e soluções.

Não raramente, encontramos trabalhos sobre o LDI que apresentam um capítulo ou seção exatamente sobre o discurso sobre o LDI. Mesmo assim, apenas poucos trabalhos tratam especificamente da análise do discurso sobre o LDI. Essa observação é também bastante relevante para nossos estudos, pois parece sugerir que, mesmo quando analisamos o

\footnotetext{
${ }^{108}$ Disponível em: 〈http://www.letras.puc-rio.br/eventos_let/4silid/anais/III\%20SILID\%20II\%20SIMAR.pdf>. Acesso em: 24 nov. 2013.

${ }^{109}$ Cf. APÊNDICE.
} 
discurso sobre o LDI, não o temos como um outro funcionamento discursivo; ou seja, não nos damos conta de que o objeto de nossa análise já é outro.

Ao retirarmos o foco investigativo das páginas do LDI, redirecionando nosso olhar para aqueles que falam sobre o LDI, estaremos atentando à necessidade de entendermos o impacto dos funcionamentos discursivos em nossa sociedade em relação à educação e as consequências desses discursos para o contexto pedagógico.

\section{Considerações sobre o capítulo}

Este capítulo buscou realizar um breve percurso do LDI desde a criação da cadeira de língua inglesa no Brasil em 1809 até o início do século XX. Vimos que os primeiros livros didáticos utilizados para o ensino de inglês no Brasil foram livros importados da Inglaterra ou de Portugal. A produção do livro didático nacional teve um início tímido a partir de 1827 , apresentando-se mais expressivamente a partir de 1880.

Foi possível perceber que o livro didático (e também, especificamente, o LDI) tem sido historicamente representado como um livro que deve ensinar ambos, o aluno e também o professor. Essa dupla incumbência do LDI acaba reforçando seu poder de discurso de verdade; pois, não apenas ensina o professor sobre questões da língua, da cultura etc., complementando sua formação profissional, como também ensina o professor a ensinar, ditando sequências de conteúdos, oferecendo respostas aos exercícios, explicitando procedimentos pedagógicos etc..

Vimos, também, que as pesquisas relacionadas ao LDI não enfatizam a diferença entre estudar o discurso do LDI, tendo-o como objeto, e investigar o discurso que fala sobre o LDI. Muitas pesquisas abordam ambos os objetos, sem distingui-los em suas especificidades. Acreditamos que essa diferenciação seja necessária para que, ao tomarmos o LDI como objeto, possamos investigar os efeitos do discurso que se materializa em suas páginas e que, ao tomarmos o discurso daqueles que falam sobre o LDI, possamos perceber o papel que se espera que o LDI assuma em nossa sociedade. Além disso, diferenciadas, essas abordagens poderiam resultar em um número maior de pesquisas mais específicas.

Tratamos, no presente trabalho, do discurso sobre o LDI e, portanto, desejamos perceber o modo de funcionamento desse discurso em nossa sociedade e também como o LDI é visto por aqueles que falam sobre ele. Para isso, observaremos, a seguir, as relações entre LDI e verdade (como saberes), que nos ajudarão a pensar sobre o funcionamento do LDI em nossa sociedade. 


\section{CAPÍTULO 2}

\section{VERDADE E LIVRO DIDÁTICO: um instrumento oficial e legitimado}

Neste capítulo, nos interessa perceber o papel do livro didático em nossa sociedade. Para isso, pesquisamos algumas relações entre o livro didático e o poder regulador do Estado, o mercado editorial e entre a disciplina de inglês e a sociedade. Em seguida, investigamos a construção histórica da representação do livro didático como um discurso de verdade e a relação entre o discurso de verdade e o discurso sobre o LDI. Acreditamos que essas relações podem nos ajudar a perceber o modo de funcionamento do livro didático como um objeto simbólico, ou seja, um meio pelo qual circula a ideologia que se deseja impor como dominante.

\subsection{O livro didático e o Estado}

O livro didático sempre esteve sob os olhos do Estado e dependente de sua aprovação, através da assinatura do soberano, presidente ou de um de seus ministros. Bittencourt (2004, p. 490) ainda afirma, "A comercialização do livro didático, no entanto, sempre esteve dependente do Estado, quer pelo seu poder de aprovação quer como comprador". Como vimos, alguns anos após a criação do ministério responsável pela educação, foi criado o Instituto Nacional do Livro (INL), para "legislar sobre as políticas do livro didático [...], contribuindo para dar maior legitimação ao livro didático nacional e, consequentemente, auxiliando no aumento de sua produção" ${ }^{\text {110 }}$. Com isso, percebemos que sempre houve a preocupação com o controle dos órgãos oficiais sobre o livro didático em relação à sua legitimação, produção e circulação.

O PNLD, Programa Nacional do Livro Didático, criado através do Decreto $\mathrm{n}^{\circ} 91.542$ de 19 de agosto de 1985 pelo Fundo Nacional de Desenvolvimento da Educação ${ }^{111}$, foi precedido por outros instrumentos que também objetivavam legislar e controlar a produção e a circulação de livros didáticos no Brasil.

\footnotetext{
${ }^{110}$ Citado de <http://www.fnde.gov.br/index.php/pnld-historico $>$. Acesso em: 15 mar. 2011.

${ }^{111}$ O FNDE, autarquia federal vinculada ao MEC, foi criado pela Lei 5.537 em 21 de novembro de 1968, sob o governo de Costa e Silva.
} 
O primeiro desses instrumentos foi a Comissão Nacional do Livro Didático (CNLD), criada pelo Decreto-lei n. 1.006 de 30 de dezembro de 1938. Em 1945, pelo Decreto-lei n. 8.460 de 26 de dezembro de 1945, fica consolidada a legislação sobre as condições de produção, importação e de utilização do livro didático. $\mathrm{O}$ artigo cinco desse decreto ${ }^{112}$ confere ao professor a escolha dos livros que deverão ser adotados; diz o artigo: "sendo livre aos professores de ensino primário, secundário, normal e profissional a escolha de livros para uso dos alunos, uma vez que constem da relação oficial das obras de uso autorizado". Vemos que, já em 1945, a escolha do livro didático era controlada pelo Estado, mas discursivisada como sendo uma ação que o professor deveria realizar. O controle era exercido através do oferecimento de uma relação de livros aprovados dentre os quais o professor escolheria aquele com o qual trabalharia ${ }^{113}$.

Em 1966, a Comissão do Livro Técnico e Livro Didático (COLTED) é criada a partir de um acordo entre o MEC e a USAID, Agência Norte-Americana para o Desenvolvimento Internacional, principal financiadora do programa. O objetivo da Comissão era coordenar a produção, a edição e a distribuição do livro didático. Carmagnani (1999) nos lembra de que, nessa época, muitos livros didáticos eram traduzidos para o português ou, se produzidos no Brasil, seus conteúdos eram rigidamente controlados. Ainda segundo Carmagnani, que descreve o acordo como tendo "resultados desastrosos" (CARMAGNANI, A., 1999, p. 46), críticos da educação, como Saviani e Ribeiro ${ }^{114}$, denunciam que esse controle exercido pela agência USAID se deu em "vários níveis da educação".

Em 1971, O INL cria o Programa do Livro Didático para o Ensino Fundamental, o PLIDEF. Nesse mesmo ano, o acordo entre o MEC e a USAID chega ao término, exigindo que os custos com os livros didáticos sejam repassados para os estados. Cinco anos depois, em 1976, o INL é extinto e a Fundação Nacional do Material Escolar (FENAME) é criada e recebe recursos do Fundo Nacional de Desenvolvimento da Educação (FNDE). Em 1983, a FENAME é substituída pela Fundação de Assistência ao Estudante (FAE), que assume o PLIDEF. Em 1985, através do Decreto nº 91.542, o Programa Nacional do Livro Didático (PNLD) é criado e substitui o PLIDEF.

\footnotetext{
112 Disponível em: 〈http://www.jusbrasil.com.br/diarios/2617701/dou-secao-1-28-12-1945-pg-8/pdfView>. Acesso em: 15 mar. 2011.

${ }_{113}$ Analisaremos esse artigo no Capítulo 5, item 5.1.3.

${ }^{114}$ SAVIANI (1980) e RIBEIRO (1982) apud CARMAGNANI, A., 1999, p. 46.
} 
Segundo o FNDE ${ }^{115}$, a criação do PNLD trouxe diversas mudanças para o cenário educacional naquele momento, como:

- Indicação do livro didático pelos professores;

- Reutilização do livro, implicando a abolição do livro descartável e o aperfeiçoamento das especificações técnicas para sua produção, visando maior durabilidade e possibilitando a implantação de bancos de livros didáticos;

- Extensão da oferta aos alunos de $1^{\mathrm{a}}$ e $2^{\mathrm{a}}$ série das escolas públicas e comunitárias;

- Fim da participação financeira dos estados, passando o controle do processo decisório para a FAE e garantindo o critério de escolha do livro pelos professores.

Tais mudanças, porém, não foram concretizadas imediatamente. Em 1992, o orçamento limitado restringe a distribuição de livros didáticos para os quatro primeiros anos do Ensino Fundamental. No ano seguinte, pela Resolução n. 6 de julho ${ }^{116}$, o FNDE garante a verba necessária para adquirir e distribuir os livros didáticos e, nos anos que se seguem, foram distribuídos os livros didáticos de matemática, português (em 1995), ciências (em 1996) e geografia e história (em 1997).

É preciso lembrar, ainda, que essas mudanças que a criação do PNLD traria ao cenário educacional, como argumentou o FNDE em 1985, não encontram sustentação naquilo que o PNLD 2011estabeleceu para a adoção do livro didático de inglês. Elencada como a segunda dessas mudanças, a "reutilização do livro, implicando a abolição do livro descartável", não se aplica agora ao LDI. Ao contrário, o PNLD 2011 exige que os livros de língua estrangeira sejam consumíveis, mas não informa sobre os motivos dessa exigência nem faz remissão àquela que fora considerada uma importante mudança. A falta de argumentação sobre a exigência de os livros de LE serem descartáveis (ou "consumíveis", termo economicamente ajustado aos documentos do PNLD 2011) produz o efeito de naturalização de sentido. Isto é, no discurso dos documentos do PNLD 2011, é natural que o livro de LE seja consumível. Essa naturalização acaba diminuindo as diferenças entre as disciplinas de LE (inglês e espanhol) e as demais disciplinas do currículo; principalmente, a diferença entre o processo de

\footnotetext{
${ }^{115}$ Com a edição do Decreto $n^{\circ}$ 91.542, de 19/8/85, o PLIDEF dá lugar ao Programa Nacional do Livro Didático (PNLD). Disponível em: 〈http://www.fnde.gov.br/index.php/pnld-historico〉. Acesso em: 15 mar. 2011.

${ }^{116}$ Essa Resolução do FNDE n ${ }^{\circ}$ 6, de julho de 1993, que objetivava a organização dos recursos para a aquisição do livro didático para as escolas públicas, encontra-se referida no site do FNDE (disponível em: $\langle$ http://www.fnde.gov.br/index.php/programas-livro-didatico>; acesso em: 18 mar. 2011) e referida, também, amplamente em muitos textos e trabalhos acadêmicos disponíveis na internet; porém, o texto da resolução não pôde ser encontrado para análise em lugar algum, inclusive no site do DOU que, aliás, disponibiliza, para essa data, a Lei Zico, que foi revogada pela Lei Pelé, mas que nada tem a ver com o FNDE.
} 
aprendizagem de uma língua estrangeira, que agora exige o livro consumível, e outra disciplina já tradicional, que adota o livro reutilizável. Já no início do Edital de Convocação para a inscrição das coleções para o PNLD 2011, o item três (Da caracterização das coleções didáticas) informa:

3.4. As coleções a que se refere o subitem 3.1 serão, obrigatoriamente, compostas de livros não-consumíveis, exceção feita aos componentes curriculares de Língua Estrangeira Moderna (Língua Inglesa e Língua Espanhola).

3.4.1. As coleções de Língua Estrangeira Moderna (Língua Inglesa e Língua Espanhola) serão, obrigatoriamente, compostas de livros consumíveis.

Assim, a falta de argumentação sobre a necessidade de os livros de LE não serem reutilizáveis produz o sentido de que não aprendemos uma língua estrangeira do mesmo modo que aprendemos a língua portuguesa ou matemática, geografia etc., ao mesmo tempo em que isenta o PNLD 2011 de detalhar a representação de aprendizagem de LE pressuposta pelo programa.

O processo de escolha dos livros didáticos inscritos no programa que conhecemos hoje foi iniciado em 1996, para o PNLD 1997, e, juntamente com o Guia do Livro Didático, permanece até hoje. Em 1997, o FNDE assume o controle para a execução do PNLD, que é ampliado para adquirir livros didáticos de alfabetização, matemática, português, ciências, estudos sociais, história e geografia para todo o Ensino Fundamental da rede pública de ensino.

No ano 2000, dicionários de língua portuguesa são também distribuídos aos alunos dos primeiros anos do Ensino Fundamental. Uma conquista desse ano foi a entrega dos livros didáticos antes do início do ano letivo, ou segundo o $\mathrm{FNDE}^{117}$, "pela primeira vez na história do programa, os livros didáticos passam a ser entregues no ano anterior ao ano letivo de sua utilização”. O Fundo informa, também, que os livros didáticos para o uso em 2001 foram entregues até 31 de dezembro do ano anterior.

Em 2001, o PNLD iniciou a oferta gradativa de livros didáticos escritos em Braille. Em 2002 e 2003, o PNLD continuou com a tarefa de distribuição de materiais didáticos complementares, como dicionários e atlas. Em 2005, há a reestruturação no modo de distribuição desses materiais; agora os materiais são distribuídos às escolas e não diretamente aos alunos. É feita, também, uma gradação dos dicionários, relacionando o número de palavras ao nível de aprendizado do aluno.

${ }^{117}$ Cf. 〈http://www.fnde.gov.br/index.php/pnld-historico>. Acesso em: 15 mar. 2011. 
Além da distribuição e complementação do material didático, em 2006, o Programa distribui às escolas de $1^{\mathrm{a}}$ à $4^{\mathrm{a}}$ série dicionários enciclopédicos ilustrados trilíngue, que contém palavras na língua portuguesa, língua inglesa e na língua brasileira de sinais (libras). Essa medida poderia ser questionada se levarmos em conta que até antes de 2008 o inglês não compunha a grade curricular das escolas públicas desse segmento. Apenas com o Parecer CNE/CEB n. 4/2008, publicado no Diário Oficial da União de 10 de junho de 2008 sobre a Lei n. 11.274 de 2006 que determina a duração de nove anos ${ }^{118}$ para o Ensino Fundamental, a disciplina de língua estrangeira é introduzida como optativa nos primeiros anos do Ensino Fundamental. Talvez por ser uma opção da escola, não houve qualquer tipo de planejamento ou determinação para a inclusão do ensino de LE nesse segmento, nem em relação aos conteúdos, nem aos materiais. A única exigência feita foi em relação ao professor que deveria ser licenciado na disciplina. Portanto, essa distribuição de dicionários trilíngues não se alinha às necessidades do aluno nem às demandas do currículo desse segmento escolar, deixando apenas perguntas sem respostas. O Ensino Médio, por sua vez, recebeu mais de dezoito milhões de livros em 2007, completando-se gradativamente o fornecimento de livros de todas as disciplinas incluídas no programa em 2008.

Pela Resolução FNDE n. $60^{119}$, a partir de 2010, é preciso que as escolas da rede pública estadual, federal e municipal adiram ao programa para que possam receber os materiais didáticos. Para o PNLD 2011, que pela primeira vez inclui a disciplina de língua estrangeira, o procedimento de adesão também foi exigido, através do documento Orientações para o registro da escolha do PNLD $2011\left(6^{\circ} \text { ao } 9^{\circ} \text { ano }\right)^{120}$. Esse documento, além de instruir sobre a adesão ao programa, prazos, uso, guarda e sigilo da senha da escola, detalhes sobre o registro da escolha, opções de escolha, recebimento compulsório das coleções caso a escolha não seja feita pela escola, informa, também, como a escola pode registrar e divulgar o processo de escolha, para maior transparência. No último item, o documento remete às normas de conduta no âmbito da execução dos programas do livro didático, a Portaria Normativa n. $7^{121}$.

\footnotetext{
118 O parecer homologado, PARECER CNE/CEB n. 12/2010, aprovado em 8 de julho de 2010, e demais pareceres e resoluções sobre o Ensino Fundamental com duração de nove anos estão disponíveis em: <http://portal.mec.gov.br >. Acesso em: 19 de mar. 2011.

${ }^{119}$ Essa resolução foi alterada pela Resolução ${ }^{\circ}$ 10, de 10 de março de 2011, dispondo sobre o PNLD para a educação básica. Disponível em: 〈http://www.fnde.gov.br/index.php/leg-res-2011〉. Acesso em: 20 mar. 2011.

${ }^{120}$ Os documentos Orientações para o registro da escolha e Compromissos da escola estão disponíveis em: < ftp://ftp.fnde.gov.br/web/livro didatico/pnld2011 compromissos da escola.pdf>. Acesso em: 23 ago. 2010.
}

121 Cf. ANEXO A. Disponível em: <ftp://ftp.fnde.gov.br/web/resolucoes_2007/por007 05042007 norma de conduta_programas_livros.pdf $>$.

Acesso em: 23 ago. 2010. 
Ainda para fazer a escolha dos livros, a escola deve assinar o documento denominado Compromissos da escola. Desmembrados em subitens, há quatro compromissos: 1) Compromissos relativos à moralidade e isonomia no processo de escolha; 2) Compromissos relativos à conservação, devolução e remanejamento dos livros; 3) Compromissos relativos ao uso, guarda e sigilo da senha e do código de segurança e escolha; 4) Compromissos relativos à transparência no processo de escolha. Portanto, vemos que a escolha é, ao mesmo tempo, atribuída ao professor e cercada de ações governamentais que, agindo através de documentos oficiais, impõem sobre ela o controle regulador.

É importante ressaltar que, ao assinar o Termo de Adesão constante no documento Orientações para o registro da escolha, a escola receberá compulsoriamente os livros que tiveram o maior número de pedidos. Para que o envio não seja automático e a escola possa escolher os livros que deseja receber, ela deverá realizar o registro da escolha através de sua senha pela internet. $\mathrm{O}$ item 7.5 do documento citado acima informa:

7.5. Se a escola não realizar o registro da escolha nem declarar que não deseja receber os livros, serão encaminhados, compulsoriamente, os títulos mais escolhidos do município/estado, desde que o gestor local tenha aderido ao PNLD por meio do Termo de Adesão.

Portanto, se a escola efetuar a adesão ao programa, mas não dispensar tempo para preencher e enviar o registro da escolha via internet, a escola e o professor perdem o direito de escolha e devem trabalhar com os livros que a maioria das escolas de seu município ou estado escolheram. Por outro lado, se a escola não informar que não deseja receber os livros didáticos, ela ainda receberá aqueles que a maioria das escolas de sua região escolheu.

Resta-nos saber o que seria feito desses livros recebidos sem terem sido requisitados pelas escolas. O documento Compromissos da escola prevê a devolução do material não utilizado, para encaminhamento à reserva técnica ou remanejamento para outras escolas. Sobre isso, observamos que, apesar de não ter sido confirmada a relação entre o recebimento compulsório do livro didático e o descarte irregular, as denúncias de descartes de livros e outros materiais didáticos estão ocorrendo. No dia 20 de fevereiro de 2013, a mídia veiculou a notícia de que um contêiner de uma empresa de reciclagem foi encontrado no dia 18 do mesmo mês na cidade de Rio Claro (SP) carregado com livros didáticos e apostilas não 
descaracterizados que seriam reciclados ${ }^{122}$. Em 19 de fevereiro de 2013, alguns exemplares foram levados à delegacia local para abertura de boletim de ocorrência.

Entre os materiais descartados, estavam as apostilas Cadernos do Programa São Paulo Faz Escola. As apostilas do programa São Paulo Faz Escola foram substituídas pelos livros didáticos do PNLD em muitas escolas; em outras, os professores mantém as apostilas e não adotam o LD. De todo o modo, o descarte ${ }^{123}$ de materiais didáticos em condições de vencidos por problemas de validade de prazo de utilização, contaminação por enchente, roedores e por desgaste, caracterizando os livros como inservíveis, é de responsabilidade da escola. Na ocorrência de algum desses eventos, inclusive após o período de validade estipulado pelo MEC-FNDE, correspondendo ao ciclo de três anos do programa do PNLD, o descarte é permitido e deve ser registrado no documento produzido pela escola denominado Ata de Desfazimento de Bem Público. Após a reunião para a resolução do descarte, esse documento deve ser emitido e conter as assinaturas da direção, da Associação de Pais e Mestres e demais representantes de professores e alunos. Os livros e apostilas devem ser descaracterizados (separadas as capas dos miolos) e o descarte (reciclagem do papel) deve ser acompanhado por um funcionário da escola.

Contudo, outro tipo de descarte tem sido denunciado. Já em primeiro de março de 2013, foi veiculada a notícia que, no Município de Tartarugalzinho (AP), centenas de livros didáticos ainda embalados destinados ao ano letivo de $2013^{124}$ foram encontradas abandonadas em um terreno da região. Os materiais descartados estavam ainda embalados e com a identificação da editora, do órgão público remetente, do programa, da escola etc. .

Parece-nos, portanto, que há ainda espaço para medidas mais realistas em relação ao percurso do livro didático desde o registro de escolha até a chegada desse material para sua utilização na escola, principalmente no que se refere ao envio automático dos livros às escolas que não se manifestam contra o recebimento dos livros após a assinatura do Termo de Adesão.

122 O vídeo da reportagem está disponível em: <http://globotv.globo.com/eptv-sp/jornal-regional-saocarlosararaquara/v/policia-investiga-descarte-de-livros-didaticos-em-escola-de-rio-claro-sp/2418251/>. $\quad$ Acesso em: 04 jul. 2013.

${ }^{123}$ Cf. informações do documento intitulado Descarte de livros didáticos expedido pelo Governo do Estado de São Paulo. Disponível em:

<http://desul3.edunet.sp.gov.br/E_Assuntos\%20do\%20Site/Descarte de Livros_Did\%C3\%A1ticos_2012.pdf $>$. Acesso em: 26 fev. 2013.

${ }^{124}$ Segundo o Promotor de Justiça em exercício na Comarca de Ferreira Gomes, Horácio Coutinho, que atendeu à denúncia dos moradores da região, os livros seriam destinados às escolas estaduais e municipais de Tartarugalzinho, Pracuúba, Amapá, Calçoene e Ferreira Gomes, no estado do Amapá, para o ano letivo de 2013, e estavam jogados a céu aberto e em processo de deterioração. Disponível em: <http://www.correaneto.com.br/site/noticias/38542>. Acesso em: 24 mar. 2013. 
É preciso dizer ainda que o processo de adoção do livro didático não se dá na relação direta entre os órgãos públicos (MEC, FNDE), através de seus programas (PNLD), e as escolas. Há, ainda, outro eixo que compõe esse complexo de relações e se inclui no processo desde seu início: as editoras. Portanto, a seguir, trataremos da relação entre as ações governamentais e as editoras envolvidas no programa.

2.2 O livro didático de inglês e o mercado editorial

O documento Edital de Convocação para Inscrição no Processo de Avaliação e Seleção de Coleções Didáticas para o Programa Nacional Do Livro Didático, sob a responsabilidade do Ministério da Educação, do Fundo Nacional de Desenvolvimento da Educação e da Secretaria de Educação Básica (SEB), instrui as editoras sobre como as coleções devem ser elaboradas para que sejam aceitas para a inscrição no programa ${ }^{125}$. Além disso, os documentos que mencionamos no item anterior, Orientações para o registro da escolha do PNLD 2011, Compromissos da escola, assim como as normas de conduta emitidas por Portarias e amplamente divulgadas às escolas e editoras, tentam garantir a transparência do processo de escolha das coleções e, também, proteger as escolas da pressão do mercado editorial. Segundo a pesquisadora Cassiano ${ }^{126}$,

Em razão dos abusos cometidos por parte das editoras em suas práticas de divulgação, que se manifestam de variadas formas, o MEC instituiu a Portaria 2.963, em 29/08/2005, contendo normas de conduta para as editoras participarem do processo de execução dos programas estatais de livros. Como muitas das tradicionais práticas de divulgação das editoras se mantiveram, em 5 de abril de 2007 essa Portaria foi substituída pela Portaria Normativa $\mathrm{n}^{\circ} 7$, em que as normas de condutas para as editoras ficaram mais rígidas, prevendo-se multas punitivas e até suspensão do contrato estabelecido entre o MEC e a editora infratora, no caso de reincidência no descumprimento da Lei.

Entre esses "abusos", os mais conhecidos são as palestras realizadas nas escolas para a divulgação de materiais e a distribuição gratuita de folhetos, amostras de paradidáticos, livros, dicionários e até coleções inteiras aos professores. Como lemos acima, Cassiano informa que, mesmo com a Portaria de 2005, divulgando as normas de conduta que as editoras devem seguir para participar do programa, as transgressões continuaram. Um novo documento, a

\footnotetext{
${ }^{125}$ Sobre os itens constantes do Edital, veja 4.1 adiante.

126 CASSIANO, C. C. F. (s/d), Mercado editorial escolar do século XXI: livros didáticos, apostilas e formação de professores. $\quad$ Disponível em: <www.utp.br/Cadernos de Pesquisa/.../2 mercado_editorial_cp6.pdf $>$. Acesso em: 25 fev. 2013.
} 
Portaria Normativa n.7 de 05 de abril de 2007, precisou ser criado para enrijecer o controle sobre a conduta das editoras, conhecida como lobby editorial, em relação ao processo de escolha das coleções. O esforço para a contenção do lobby pode ser lido principalmente no artigo três dessa Portaria, que estabelece proibições às editoras (parágrafo três), obrigações das Secretarias de Educação dos Estados, Municípios e Distrito Federal (parágrafo quatro) e obrigações da escola (parágrafo cinco). Destacamos abaixo alguns excertos de cada um desses parágrafos. O texto integral da Portaria Normativa n.7 encontra-se no ANEXO A.

$\S 3^{\circ}$ Constituem-se proibições aos Titulares de Direitos Autorais ou aos seus representantes, cujas obras inscritas forem selecionadas:

$[\ldots]$

II - distribuir presentes ou brindes a pessoas ou instituições vinculadas ao processo de escolha, no âmbito dos Programas do Livro, a qualquer título, após a publicação do resultado da avaliação ou a divulgação dos guias de escolha pelo MEC/FNDE, até o final do período de escolha pela internet e pelo formulário impresso;

$[\ldots]$

VIII - realizar pessoalmente a divulgação ou entrega de qualquer material de divulgação dos livros, diretamente nas Escolas, após a publicação do resultado da avaliação ou a divulgação dos guias de escolha pelo MEC/FNDE, até o final do período de escolha pela internet e pelo formulário impresso, sendo permitida, durante esse período, a divulgação pelo envio de livros, catálogos, folders e outros materiais, exclusivamente por remessa postal, definida como a entrega de materiais de forma impessoal, pelos Correios ou forma equivalente, sem a presença do Editor ou seu preposto ou outrem com vínculo funcional evidente com o Titular de Direito Autoral;

$\S 4^{\circ}$ Constituem-se obrigações das Secretarias de Educação dos Estados, Municípios e Distrito Federal:

$[\ldots]$

III - impedir a participação dos Titulares de Direitos Autorais, autores, ou de seus representantes, nos eventos promovidos pelas Secretarias de Educação relativos à escolha de livros;

$\S 5^{\circ}$ Constituem-se obrigações das Escolas:

I - impedir o acesso, em suas dependências, de Titulares de Direitos Autorais ou de seus representantes com o objetivo de divulgar livros referentes aos Programas do Livro, após a publicação do resultado da avaliação ou a divulgação dos guias de escolha pelo MEC/FNDE até o final do período de escolha pela internet e pelo formulário impresso;

Percebemos que esses dizeres, ao estabelecerem obrigações e proibições, confirmam a ocorrência de lobby editorial até aquele momento. Tal confirmação pode ser percebida pelos efeitos de pré-construído no dizer. Isto é, se é necessário proibir o acesso é porque esse acesso ocorria; se é proibido distribuir presentes é porque eles eram distribuídos e assim por diante. É 
interessante observar que no parágrafo quatro, sobre as obrigações das Secretarias de Educação, os itens I e VI nos levam à conclusão de que as vantagens não eram oferecidas apenas pelos autores e editoras. Dizem os itens:

I - recusar vantagens de qualquer espécie em razão da escolha das obras no âmbito dos Programas do Livro;

VI - recusar vantagens de qualquer espécie dos Titulares de Direitos Autorais ou de seus representantes, a titulo de doação, como contrapartida da escolha realizada no âmbito dos Programas do Livro;

Ou seja, enquanto no item VI sabemos que as vantagens que devem ser recusadas são oferecidas pelos autores, editoras ou seus representantes (Titulares de Direitos Autorais), no item I as Secretarias de Educação devem ainda recusar as vantagens, mas não há informação sobre quem as estaria oferecendo. O primeiro item do parágrafo, o item I, não tem o caráter de uma condição geral que introduziria subitens. Ao contrário, é um item integral, assim como o item VI, o penúltimo do parágrafo. Ambos têm, portanto, o mesmo peso no documento, referem-se à mesma proibição, à mesma situação, com a diferença de que, no item I, não sabemos quem estaria oferecendo as vantagens.

Com as proibições e as penalidades aos infratores informadas na Portaria Normativa n.7, outras medidas foram tomadas pelas editoras, cujo alto poder de investimento lhes tem possibilitado desenvolver estratégias atuais, sofisticadas e muitas vezes dispendiosas nessa corrida acirrada para terem seus títulos aprovados no Programa. Entre essas estratégias estão o oferecimento e/ou patrocínio de palestras, congressos nacionais e internacionais ${ }^{127}$, cursos de atualização profissional, concursos culturais com distribuição de cestas de livros, canal do professor em seus sites e blogs que disponibilizam atividades para impressão, jogos, orientações didáticas, materiais de áudio etc. ${ }^{128}$. É interessante observar que todos esses oferecimentos trabalham no lugar mesmo em que a formação do professor falta. Portanto, há o reconhecimento dessa falta pelo próprio professor que busca esses recursos, pelo mercado editorial que os oferece e pela sociedade que os valida e reconhece. Mas, é preciso questionar a função do conhecimento como produto. Isto é, o conhecimento já construído em outro lugar

\footnotetext{
${ }^{127}$ Sobre eventos patrocinados pelas editoras, veja CASSIANO, C. C. F. (op. cit., s/d, p. 21). Disponível em: <www.utp.br/Cadernos de Pesquisa/.../2 mercado_editorial_cp6.pdf>. Acesso em: 25 fev. 2013.

128 Como por exemplo, a gama de eventos informados no site da Editora Moderna, entre eles: o Congresso Internacional sobre a Educação, Congresso Internacional de Tecnologia de Educação, Seminário Internacional de Gestão em Educação, entre outros. Disponível em: 〈http://redes.moderna.com.br〉. Acesso em: 26 fev. 2013.
} 
que vem tamponar ${ }^{129}$ a falta que instigaria a busca pelo conhecimento como processo de construção.

Além dessas estratégias empregadas pelas editoras, outra mais direta e que tem se mostrado bastante eficaz para conseguir a participação mais expressiva no Programa talvez seja a formação de grupos editoriais.

Segundo Britto ${ }^{130}$ (2001), no período entre 1998 e 2006, noventa por cento das aquisições feitas pelo FNDE contemplavam dezessete editoras: FTD, Ática, Saraiva-Atual, Scipione, Moderna, IBEP, Brasil, Nova Geração, Dimensão, Victor Civita, Base, Nova Fronteira, Quinteto, Nacional, Ediouro, Schwarcz e Formato. Como informam Britto (2001) e Cassiano (s/d), atualmente, doze dessas dezessete editoras compõem os grupos: Abril (controladora da Ática, Scipione e Victor Civita), Santillana (controladora da Moderna e Objetiva), IBEP (que adquiriu a Nacional), FTD (que adquiriu a Quinteto), a Saraiva (que adquiriu a Atual e a Formato, além da livraria Siciliano em 2008) e a Ediouro (que adquiriu a Nova Fronteira e a Geração Editorial). Britto (2001, p. 12) afirma:

Estimativas apontam que a indústria dos didáticos representa cerca de 54\% da indústria nacional de livros. No que tange à concentração do segmento, tem-se, do lado da demanda, um quase monopsônio (no ensino fundamental, por exemplo, o Estado responde pela aquisição de aproximadamente $90 \%$ dos livros publicados); do lado da oferta, configura-se um oligopólio (poucas editoras vêm concentrando o maior volume de compras do FNDE ao longo do tempo).

Se, por um lado, o fortalecimento dos grupos editoriais e o volume de compra de livros didáticos favorecem a redução dos preços de aquisição se comparados aos do mercado das livrarias, por outro, o investimento do programa fica concentrado em poucos grupos editoriais. Segundo o documento Valores Negociados PNLD 2011, disponibilizado pelo site do FNDE $^{131}$, a tiragem total foi de 135.669.202 livros, perfazendo a quantia de R\$880.263.266,15. Porém, o documento Resumo Físico Financeiro, que inclui as obras complementares e foi publicado pela Coordenação Geral dos Programas do Livro através do site do FNDE, informa que a tiragem total de livros para o PNLD 2011 foi de 137.556.962, correspondendo ao valor total do programa de $\mathrm{R} \$ 1.022 .564 .752,98$.

\footnotetext{
${ }^{129}$ Cf. nota 105.

130 BRITTO, T. F. O livro didático, o mercado editorial e os sistemas de ensino apostilados. In: Centro de Estudos da Consultoria do Senado, Textos para Discussão 92. Jun. 2011. Disponível em: <http://www.senado.gov.br/conleg/centroaltosestudos1.html>. Acesso em: 23 fev. 2013.

${ }^{131}$ Cf. <PNLD 2011 - Valores de aquisição por editora - Ensino -FNDE〉. Disponível em: 〈www.fnde.gov.br〉. Acesso em: 5 mar. 2013.
} 
Considerando-se o documento Valores Negociados PNLD 2011 (Fig. 1, abaixo), que informa os números por editoras, temos aproximadamente $46,5 \%$ do valor total do programa concentrado nas três editoras (Ática, Saraiva e Scipione) que tiveram suas obras de língua estrangeira moderna aprovadas, além dos materiais para outras disciplinas. Esse total corresponde à aquisição de oitocentos e doze títulos, perfazendo aproximadamente $44 \%$ dos 1.846 títulos adquiridos, para a tiragem total de 135.669.202 livros.

Fundo Nacional de Desenvolvimento da Educação
Programa Nacional do Livro Didático - PNLD 2011
Ensino Fundamental e Médio - Valores Negociados

\begin{tabular}{|c|c|c|c|c|c|c|c|}
\hline EDITORA & $\begin{array}{l}\text { TIRAGEM } \\
\text { TOTAL }\end{array}$ & $\begin{array}{c}\text { TÍTULOS } \\
\text { ADQUIRIDOS }\end{array}$ & $\begin{array}{l}\text { TIRAGEM } \\
\text { MÉDIA }\end{array}$ & $\begin{array}{c}\text { CADERNOS } \\
\text { TIPOGRÁFICOS }\end{array}$ & $\begin{array}{c}\text { R\$/ } \\
\text { CADERNO }\end{array}$ & $\begin{array}{c}\text { RS / } \\
\text { EXEMPLAR }\end{array}$ & VALOR TOTAL \\
\hline MODERNA & 27.466 .376 & 222 & 123.722 & 483.017 .540 & 0,3344 & 5,88 & $161.366 .197,83$ \\
\hline FTD & 26.028 .717 & 288 & 90.377 & 482.657 .871 & 0,3378 & 6,26 & $162.933 .319,18$ \\
\hline ÁTICA & 25.728 .190 & 306 & 84.079 & 442.273 .340 & 0,3355 & 5,76 & $148.288 .428,80$ \\
\hline SARAIVA & 21.085 .672 & 254 & 83.014 & 403.935 .684 & 0,3478 & 6,66 & $140.390 .289,36$ \\
\hline SCIPIONE & 19.555 .764 & 252 & 77.602 & 349.364 .170 & 0,3444 & 6,15 & $120.230 .592,21$ \\
\hline POSTITVO & 3.736 .902 & 114 & 32.780 & 53.710 .805 & 0,5066 & 7,28 & $27.187 .572,29$ \\
\hline SM & 3.612 .642 & 46 & 78.536 & 62.019 .192 & 0,4577 & 7,85 & $28.367 .191,80$ \\
\hline ESCALA & 2.830 .595 & 74 & 38.251 & 50.153 .367 & 0,5266 & 9,32 & $26.393 .247,01$ \\
\hline DO BRASII & 1.890 .855 & 88 & 21.487 & 29.380 .742 & 0,6033 & 9,37 & $17.715 .145,37$ \\
\hline AJS & 1.222 .250 & 8 & 152.781 & 19.998 .123 & 0,5011 & 8,19 & $10.011 .524,51$ \\
\hline IBEP & 731.261 & 60 & 12.188 & 13.615 .872 & 0,6633 & 12,35 & $9.027 .821,46$ \\
\hline BASE & 507.718 & 38 & 13.361 & 6.905 .557 & 0,6988 & 9,50 & $4.822 .912,98$ \\
\hline NOVA GERAÇÃo & 506.417 & 6 & 84.403 & 24.336 .342 & 0,6211 & 29,84 & $15.112 .199,38$ \\
\hline NACIONAL & 458.951 & 38 & 12.078 & 5.265 .257 & 0,6633 & 7,60 & $3.489 .460,69$ \\
\hline COMPANHIA DA ESCOLA & 92.786 & 2 & 46.393 & 3.459 .010 & 0,6733 & 25,10 & $2.328 .906,02$ \\
\hline CASA PUBLICADORA & 68.909 & 8 & 8.614 & 1.371 .735 & 0,6988 & 13,90 & $958.147,23$ \\
\hline SARANDI & 67.642 & 10 & 6.764 & 1.150 .524 & 0,8322 & 14,15 & $956.997,45$ \\
\hline DIMENSÃO & 66.815 & 24 & 2.784 & 647.828 & 0,8411 & 8,15 & $544.583,97$ \\
\hline FAPI & 8.862 & 2 & 4.431 & 84.516 & 1,0700 & 10,20 & $90.432,12$ \\
\hline AYMARÁ & 1.878 & 6 & 313 & 27.728 & 1,7422 & 25,72 & $48.296,49$ \\
\hline TOTAL & 135.669 .202 & 1.846 & 73.494 & 2.433 .375 .200 & 0,3617 & 6,49 & $880.263 .266,15$ \\
\hline
\end{tabular}

Fig.1: Valores Negociados PNLD 2011

Como vimos, duas dessas editoras cujas coleções de língua estrangeira moderna foram aprovadas pelo programa (Ática e Scipione) pertencem ao mesmo grupo editorial. O grupo Abril, portanto, com 558 títulos, teve 30,2\% do total de títulos aceitos e, com a quantia de $\mathrm{R} \$ 268.519 .021,01$, recebeu $30,5 \%$ do valor total do programa em relação às dezoito outras editoras participantes.

Ainda segundo o documento acima, todos os seis grupos editoriais que mencionamos anteriormente estão representados entre as editoras cujas coleções foram aprovadas para o programa. Mesmo assim, a participação desses grupos não é tão expressiva quanto a do grupo Abril. O grupo IBEP, por exemplo, teve também duas editoras com obras aprovadas: a própria 
IBEP e a Nacional. Essas duas editoras somam noventa e oito títulos aprovados e recebimento de $\mathrm{R} \$ 12.517 .282,15$. Em relação ao preço do exemplar, apenas quatro das vinte editoras ficaram abaixo do valor médio informado no documento: as duas editoras do grupo Abril (Ática e Scipione), além da Moderna e da FTD. Vemos, portanto, que a formação de grupos editoriais pode se constituir em uma estratégia vantajosa para as editoras que participam do programa. Também no PNLD 2014, que sucedeu o PNLD 2011 no mesmo segmento $\left(6^{\circ}\right.$ ao $9^{\circ}$ ano do Ensino Fundamental), dentre as cinco coleções aprovadas, três (duas de inglês e uma de espanhol) pertencem ao mesmo grupo editorial ${ }^{132}$.

Sob a perspectiva que priorizamos neste estudo, as novas estratégias editoriais parecem corroborar o funcionamento da sociedade de controle. Isto é, parece-nos que o oferecimento gratuito de produtos e serviços online (cursos, palestras, atividades fotocopiáveis, concursos, cestas de livros etc.) substituiu a distribuição de "presentes ou brindes" $" 133$ diretamente aos professores e coordenadores nas escolas. Essa estratégia adota uma via em que se transfere àquele que acessa os sites e blogs a responsabilidade de clicar e participar, apagando a presença proibitiva daquele que presenteia e deixando exclusivamente ao professor, usuário do site ou blog, a opção de participar ou não.

Vemos também a formação de grupos editoriais como um modo de garantir o controle, apesar da aparente transparência que possa suscitar. Nesse caso das editoras, o controle se concentra sobre o lucro e sobre o escopo de atuação, tanto em relação ao segmento escolar quanto à abrangência do espaço territorial. Observamos que a existência de várias editoras apaga ou adia a percepção de que há um grupo editorial no controle, justamente pelo oferecimento de muitas opções. Tal apagamento ou adiamento corrobora a noção de que, na sociedade de controle, o poder não é localizável. Sobre a aparente diluição do controle, lembramos que Deleuze ([1990] 2008, p. 223-4), ao argumentar sobre o capitalismo de sobreprodução na sociedade de controle, disse:

O que ele quer vender são serviços, e o que quer comprar são ações. Já não é um capitalismo dirigido para a produção, mas para o produto, isto é, para a venda ou para o mercado. Por isso ele é essencialmente dispersivo, e a fábrica cedeu lugar à empresa. A família, a escola, o exército, a fábrica não são mais espaços analógicos distintos que convergem para um proprietário, Estado ou potência privada, mas são agora figuras cifradas, deformáveis e transformáveis, de uma mesma empresa que só tem gerentes.

\footnotetext{
${ }^{132}$ Cf. <http://www.canal.org.br/dilvenoejb/dilveweb/participantesficha.jsp?id=23237\&tipoent=editoriales> e <http://www.edicoessm.com.br/\#!/catalogo/pnld2014>. Acesso em 14 out. 2013.

${ }^{133}$ Cf. Portaria Normativa n.7, parágrafo 3, item II.
} 
As novas estratégias das editoras, portanto, parecem corresponder a esse funcionamento que deseja vender/oferecer serviços aos professores e comprar suas ações. Acreditamos que esse funcionamento do lobby editorial parece funcionar como uma linha de fuga ${ }^{134}$. Isso porque, segundo Deleuze ([1990] 2008, p. 212): "uma sociedade nos parece definir-se menos por suas contradições que por suas linhas de fuga". Deleuze e Guattari ([1980] 1995, p. 11) definem linhas de fuga como "movimentos de desterritorialização e desestratificação". Elas coexistem com "linhas de segmentaridade", que estratificam, territorializam e organizam o rizoma. Assim, há sempre o movimento de reorganização do rizoma.

Deleuze e Guattari definem rizoma como um sistema aberto com "princípios de conexão e de heterogeneidade" ${ }^{135}$. Há seis princípios: o Princípio de conexão estabelece que qualquer ponto de um rizoma pode ser conectado a outro; o Princípio de heterogeneidade considera que, como qualquer conexão é possível, o rizoma não segue relações de hierarquia e é, portanto, regido pela heterogeneidade; o Princípio de multiplicidade garante a incompletude do rizoma, que não se reduz a uma unidade e não é sujeito, nem objeto ${ }^{136}$; o Princípio de ruptura assignificante estabelece que é possível partir o rizoma em qualquer lugar sem implicar seu modo de funcionamento, pois, não havendo hierarquia nem significação pressuposta no rizoma, ele se reorganiza; o Princípio de cartografia defende que é possível mapear um rizoma, considerando-se suas múltiplas entradas, acessos e regiões imprevistas; o Princípio da decalcomania defende que o rizoma é um mapa e que é possível copiar um mapa e sobrepô-lo às cópias, possibilitando novas multiplicidades ${ }^{137}$. Essa teorização de Deleuze e Guattari contrapõe a imagem do rizoma, como raízes de grama ou erva daninha, à imagem de uma árvore, como uma unidade com sistema hierárquico. O rizoma deve ser pensado como uma trama em que cada e qualquer lugar das linhas dessa conexão pode e deve se conectar a outro. As linhas segmentares que organizam o rizoma podem se partir, explodindo numa linha de fuga. As linhas de fuga pertencem também ao rizoma e "não param de se remeter uma às

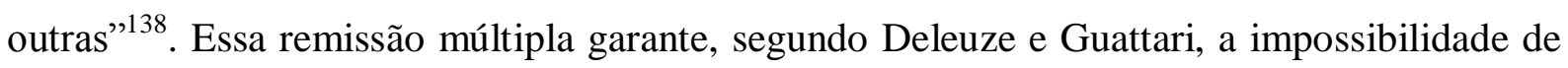

\footnotetext{
${ }^{134}$ Cf. DELEUZE, G.; GUATTARI, F. [1980] 1995. Trataremos da noção de linhas de fuga também nos capítulos de análise.

${ }_{135}^{13}$ Idem, p. 15.

${ }^{136}$ Cf. GALLO, S., 2003, p. 77.

${ }^{137}$ DELEUZE, G. e GUATTARI, F. ([1972/1973] 2010, p. 62) explicam que o conceito de multiplicidade, empregado sempre como substantivo, refere-se àquilo que é irredutível à unidade, pois supera "tanto o múltiplo quanto o Uno".

${ }^{138}$ DELEUZE, G.; GUATTARI, F.,[1980] 1995, p. 18.
} 
uma "lógica binária"139 ancorada em dualismos e dicotomias e favorece o fluxo em rede, com caminhos múltiplos ou multiplicidades ${ }^{140}$.

Desse modo, ao transferir ao usuário do site ou blog a responsabilidade sobre a participação nos eventos e premiações e ao oferecer muitas opções de editoras, as estratégias editoriais se colocam como não invasivas, não assertivas, nem conclusivas. Essa postura produz o efeito de adiamento do término, característico do funcionamento da sociedade de controle, ao mesmo tempo em que possibilita o escape ou a abertura de linhas de fuga. Pois, ao menos discursivamente, há sempre outros caminhos, outras opções, outras possibilidades e escolhas. Em outros termos, as múltiplas possibilidades oferecidas para se escolher as editoras silenciam o pertencimento dessas editoras ao mesmo grupo editorial. Assim, ao mesmo tempo em que as estratégias editoriais garantem linhas de fuga (possibilidades de escolher as editoras), elas mantêm o controle nas mãos do mesmo grupo editorial.

2.3 O programa do livro didático de inglês na escola pública

Desde a consolidação da legislação do livro didático em 1945 e com a criação do PNLD em 1985, essa política pública fundamental tem sido aprimorada para cumprir suas funções tanto em relação à produção e distribuição de livros didáticos às escolas públicas brasileiras quanto à transparência do processo, aos ajustes em relação à demanda, às correções de falhas e à coibição de fraudes e lobbies. É certo, porém, que sempre haverá espaço para novos acertos e adaptações.

Nas respostas ${ }^{141}$ dos professores ao nosso segundo questionário de pesquisa, portanto professores que utilizam o LDI do PNLD 2011, podemos perceber os pontos do programa que representam algumas de suas satisfações e seus descontentamentos. De modo geral, os professores receberam com grande entusiasmo o LDI. É interessante observar que mesmo aqueles que nos apontam mais críticas que elogios ainda têm o LDI como algo muito positivo e muito bem-vindo à escola pública.

Em relação ao aprendizado, os principais pontos positivos elencados pelos professores concernem ao apelo visual do material, que causa a motivação e o interesse do aluno; à possibilidade de o aluno estudar em casa com esse material; ao fácil acesso a textos, exercícios, à prática da pronúncia, ao conhecimento e à língua. Em relação ao ensino, os professores consideram que o LDI facilita seu trabalho de modo geral, contribui à organização

\footnotetext{
${ }^{139}$ Idem, p. 13.

${ }^{140}$ Cf. idem, p. 15.

141 Os dizeres dos professores que responderam aos questionários de pesquisa são analisados nos capítulos quatro, cinco e seis. Neste capítulo, os dizeres que destacamos nos servem como apoio para nossa argumentação.
} 
dos conteúdos a serem ensinados, oferece uma "rota" a seguir, torna as aulas mais dinâmicas, complementa as informações culturais, dispensa a produção de exercícios extras e fotocópias, traz outras formas de trabalhar os conteúdos e, ainda, torna desnecessário "escrever o conteúdo no quadro" (P10Q2 $\left.{ }^{142}\right)$. Destacamos, abaixo, alguns dizeres dos professores respondentes ao segundo questionário com apontamentos favoráveis ao LDI e ao programa.

- Vejo só vantagens porque o livro foi desenvolvido por profissionais dedicados à produção de material didático. (P14Q2)

- Me fez economizar muito também, pois como antes não havia material colorido, com visual legal, nem ilustrações, eu investia muito em montagem de apostilas e xerox de atividades diferenciadas. (P13Q2)

- O LIVRO ATENDE ÁS PROPOSTAS ESTABELECIDAS PARA O USO DIDÁTICO COM AMPLA ABORDAGEM DE VOCABULÁRIO E GRAMÁTICA ADEQUADOS À SÉRIE. (P2Q2 $\left.{ }^{143}\right)$

- O LD trás o benefício de ser um roteiro a seguir, e por isso o planejamento das aulas, se tornou mais fácil. (P7Q2)

- A utilização do livro didático foi primordial para auxiliar o professor no processo ensinoaprendizagem, pois por meio dessa ferramenta o professor pode ampliar a forma como trabalhará os conteúdos mostrando as imagens e compartilhando as informações culturais contidas nos textos. (P11Q2)

- Vantagens - não precisamos escrever o conteúdo no quadro. (P10Q2)

- O livro sempre contribui para o ensino, facilitando o ensino/aprendizado da língua; a maior vantagem é não precisarmos passar o conteúdo no quadro. (P12Q2)

- O livro didático possibilitou o acesso do aluno a uma gama maior e mais diversificada de conhecimento, tornando o conhecimento de L.I mais acessível ao aluno da escola pública. (P3Q2)

- As vantagens são: a gente pode ver alguns conteúdos em sequência e a desvantagem, aliás, outra vantagem, é que o livro trabalha muito bem alguns conteúdos de gramática. (P20Q2)

\footnotetext{
${ }^{142} \mathrm{P}$ se refere ao professor que respondeu ao questionário. Suas respostas serão analisadas como dizeres de um sujeito do discurso profissional. Seguindo a ordem de entrada nos capítulos de análise deste trabalho, P1Q1 refere-se ao primeiro sujeito-professor respondente do primeiro questionário (antes da adoção do LDI) e P1Q2 é o primeiro sujeito-professor respondente do segundo questionário de pesquisa (após o LDI já ter sido adotado) e assim por diante.

${ }^{143}$ Reproduzimos as sequências discursivas exatamente como as obtivemos nos textos originais, alterando, quando necessário, o tamanho e a cor das letras, sem realizarmos, contudo, a revisão textual. $\mathrm{O}$ uso de maiúsculas, minúsculas e abreviações nos textos originais também é respeitado.
} 
Vemos que os professores que responderam ao questionário de pesquisa reconhecem que o livro didático do PNLD 2011 é fruto do trabalho profissional que visa o bem-estar dos professores e dos alunos e que traz novas perspectivas para o ensino e para a aprendizagem da língua estrangeira na escola pública. É importante dizer que nenhum respondente se posicionou contra a adoção proposta pelo PNLD 2011 nos dois questionários. Portanto, as questões e preocupações colocadas pelos respondentes não concernem exatamente à proposta de adoção do livro didático de língua estrangeira na escola pública, mas estão relacionadas ao processo de adoção propriamente dito e à qualidade das coleções didáticas, como veremos adiante.

Uma questão ainda um tanto obscura no processo de adoção proposto pelo programa é o estabelecimento do período de três anos para a duração de cada programa e, consequentemente, para a validade de cada coleção do PNLD do Ensino Fundamental. Como sabemos, pela Lei $\mathrm{n}^{\mathrm{o}} 11.114$ de 16 maio de 2005, que inclui obrigatoriamente a classe de alfabetização no ciclo escolar, o Ensino Fundamental passa a ter nove anos de duração. A divisão desse segmento agora é composta por dois ciclos denominados anos iniciais (as antigas $1^{\mathrm{a}}, 2^{\mathrm{a}}, 3^{\mathrm{a}}$ e $4^{\mathrm{a}}$ séries passam a ser os $1^{\mathrm{o}}, 2^{\mathrm{o}}, 3^{\mathrm{o}}, 4^{\mathrm{o}}$ e $5^{\mathrm{o}}$ anos) e anos finais (as $5^{\mathrm{a}}, 6^{\mathrm{a}}, 7^{\mathrm{a}}$ e $8^{\mathrm{a}}$ séries passam a ser os $6^{\circ}, 7^{\circ} 8^{\circ}$ e $9^{\circ}$ anos). Portanto, a duração de cinco anos para os anos iniciais e quatro para os anos finais parece não justificar a troca de livros didáticos a cada três anos. Mesmo com um novo PNLD a cada três anos, cada coleção para os últimos anos do Ensino Fundamental deve apresentar quatro volumes, um para cada ano escolar. Porém, como vemos na projeção abaixo, no período correspondente ao curso, os alunos nunca utilizam os quatro volumes de cada coleção e, consequentemente, nenhuma coleção iniciada chega ao término para os alunos de um mesmo ano escolar, uma mesma turma.

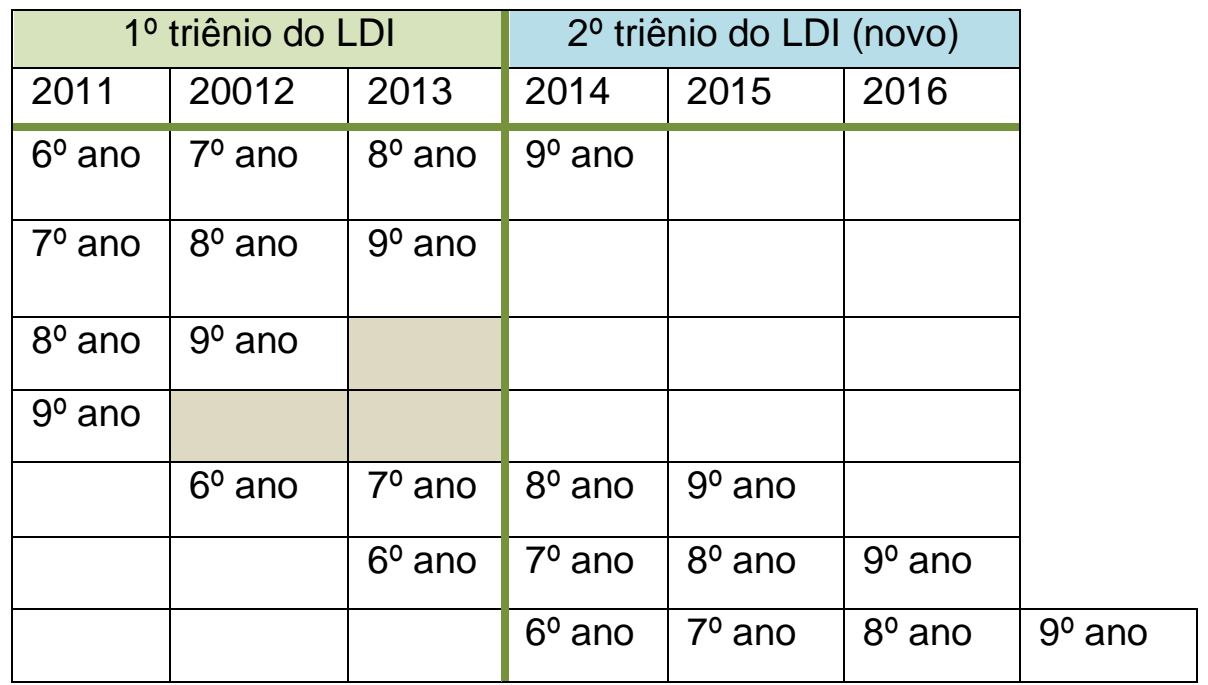

Fig. 2: Quadro de projeção da adoção trienal do LDI por ano escolar 
Portanto, parece-nos que o processo de adoção não teve como foco principal a preocupação com o aluno. Isso porque os alunos que estavam no sétimo, oitavo ou nono ano em 2011 tiveram de lidar com uma coleção já em andamento (segundo, terceiro e quarto volumes respectivamente) e planejada nos moldes do PNLD, com sua sequência própria de conteúdos, ênfase nas quatro habilidades, entre outros aspectos que, certamente, se apresentaram como novos aos alunos desses anos. Em relação ao aluno, dois aspectos adequação à realidade e ao nível de conhecimento linguístico - se repetem nos dizeres de professores que responderam ao nosso segundo questionário. Reproduzimos, abaixo, alguns desses dizeres.

- [...] minha frequência de uso desses livros em sala é rara dado o fato de que os alunos não têm pré-requisito para acompanhar a sequência do conteúdo. (P16Q2)

- Digamos que estou satisfeita 40\%, não gosto muito da sequencia didática dos livros, misturam muitos assuntos que poderiam ser abordados de forma mais gradativa, principalmente para as series iniciais, sexto e sétimo ano. (P13Q2)

- O nível de dificuldade poderia ser mais adequado/ajustado para cada série. (P15Q2)

- Os temas são muito distantes da realidade do aluno e são muito temas que não dá tempo de trabalhar tudo durante o ano. (P8Q2)

- Alguns temas são distantes da realidade dos meus alunos, o que os desestimula. (P17Q2)

- Em geral, o aluno da escola pública tem um domínio aquém do desejado e/ou esperado para o seu nível de ensino. (P19Q2)

- Não estou satisfeito "não é nem" por causa do livro e sim porque, as vezes (e muitas vezes) o conteúdo do livro não está de acordo com os conteúdos do alinhamento de conteúdo e nem com o referencial, aliás, proposta curricular. Há, faltam alguns livros para "alguns" alunos. (P20Q2)

A desconsideração do aluno, como um participante importante e decisivo no programa de adoção do LDI, e do contexto em que esse aluno se insere em relação ao processo de aprendizagem, acaba por preterir elementos cruciais envolvidos na prática de ensino que podem alterar consideravelmente todo o projeto do programa em si. Apenas para o embasamento desta nossa argumentação, citamos, abaixo, outro professor (P14Q2) que também respondeu ao nosso segundo questionário de pesquisa. 
Estou tão satisfeito com o livro didático, que ainda é difícil apontar uma deficiência nele. Porém, um ponto que penso que necessita melhora é na distribuição do livro didático, pois tenho alunos que não têm o livro e outros que só conseguiram o livro em 2012 graças a doações de outras escolas. Cabe esclarecer que alguns alunos devolveram seus livros velhos de 2011 e esses foram reutilizados em 2012, devido à falta de livro em Brumadinho. Cabe esclarecer também que, em Brumadinho, os estudantes do $6^{\circ}$ ao $9^{\circ}$ anos de escolas públicas municipais têm apenas uma aula semanal de inglês, o que impossibilita o esgotamento de um livro com apenas 40 aulas anuais. Logo, o livro previsto para o $6^{\circ}$ ano (que tem 16 unidades) é usado para o $6^{\circ}$ ano (unidades 1 a 4), para o $7^{\circ}$ ano (unidades 5 a 8 ), para o $8^{\circ}$ ano (unidades 9 a 12) e para o $9^{\circ}$ ano (unidades 13 a 16), caracterizando um aparente absurdo em minha opinião. Os livros previstos para o $7^{\circ}$ ano, $8^{\circ}$ ano e $9^{\circ}$ ano ficam na prateleira for falta de aplicação. Acredito que a solução seria prever essa lamentável realidade no processo de distribuição nacional ou o referido município aumentar a carga horária de língua inglesa, de forma a compatibilizá-la com o conteúdo pedagógico dos livros.

Vemos que o número reduzido de horas para o ensino de línguas pode ser o fator determinante dessa situação descrita pelo professor citado acima. De todo o modo, segundo as declarações desse professor, vários compromissos que o PNLD 2011 deveria garantir, como o livro consumível, a distribuição integral e a reposição anual dos livros, não foram realizados. O planejamento da carga horária dedicada ao ensino de língua estrangeira deverá, também, ser considerado pelos projetos e programas futuros sob pena de total insucesso.

Através das respostas dos professores ao segundo questionário de pesquisa, podemos perceber que outros compromissos do PNLD 2011 também não foram seguidos como planejados. Em algumas escolas, ambos os livros são adotados concomitantemente ou em anos consecutivos:

- Foi adotado o Links no ano passado e o Keep in Mind neste ano. (P16Q2)

- Até então, vejo só vantagens porque o livro foi desenvolvido por profissionais dedicados à produção de material didático. Antes da adoção do livro em 2011, eu produzia meu próprio material e, por mais que eu me esforçasse, ainda cometia alguns erros de planejamento e/ou de produção. Além disso, o livro é único (ou duplo porque temos o Keep in Mind e ou Links). (P5Q2)

- Vejo só vantagens porque o livro foi desenvolvido por profissionais dedicados à produção de material didático. Antes do livro, eu produzia meu próprio material e, por mais que eu me esforçasse, ainda cometia alguns erros de palnejamento e/ ou produção. Além disso, o livro é único (mesmo considerando as 2 coleções, os conteúdos são compatíveis). $(\mathrm{P} 14 \mathrm{Q} 2)^{144}[\mathrm{sic}]$

\footnotetext{
${ }^{144}$ Observamos que P5Q2 e P14Q2 redigiram suas respostas ao questionário de modo quase idêntico.
} 
Outros respondentes apontam, também, os problemas de distribuição dos livros ${ }^{145}$, a carga horária reduzida, o número de alunos em sala de aula e a falta de equipamentos. Como apoio para nosso dizer, citamos $\mathrm{P} 6 \mathrm{Q} 2$ em resposta à nossa quinta pergunta sobre os pontos que melhoraram e quais precisam ainda ser melhorados nesse processo de adoção.

Primeiro, a quantidade é insuficiente para todos os alunos. O livro vem com um CD que não consigo usar na sala por falta de um bom aparelho de som. Inclusive chegaram livros de espanhol em minha escola, sendo que não é lecionada essa língua e número de livros de inglês insuficientes para todos. [sic]

Esses problemas marcam o cenário em que o aluno e o professor se inserem e, no dia a dia, podem colocar em risco o êxito do programa. Ainda assim, a cada triênio o PNLD se renova e se renovam as coleções. Esse curto período exige que, imediatamente após a adoção de uma coleção, as editoras já iniciem um novo trabalho de preparo de coleções para a próxima edição do programa. Sem que se tenha ainda sentido os efeitos da coleção anterior para os necessários ajustes, o próprio programa já reinicia a elaboração dos novos documentos, editais, contato com equipes de especialistas etc. Também os investimentos, tanto profissionais quanto financeiros, são renovados a cada triênio. Como vimos no quadro Valores Negociados, acima, o volume de investimentos na faixa dos oitocentos a novecentos milhões deve também ser renovado a cada triênio. Assim, como é próprio do funcionamento das sociedades de controle, tudo ocorre, na prática, num processo contínuo em que a cada momento o fim é adiado; pois, o fim já é o próprio começo.

O ciclo trienal do PNLD é uma questão que fica ainda a ser respondida. Nesse sentido, é essencial a contribuição de todos os envolvidos, através de resultados de estudos, observações e apontamentos sobre a prática do processo de adoção de coleções didáticas na escola pública brasileira.

Quando nos referimos ao processo de adoção, incluímos aí as muitas fases que o compõem; as principais são a elaboração, a escolha, a distribuição e a reposição das coleções didáticas. Podemos perceber nesse processo o controle que legitima alguns livros didáticos

\footnotetext{
${ }^{145}$ Cf. correspondência eletrônica recebida em 13 mar. 2011: "Prezada Dolores, paz e bem. A Secretaria de Educação solicitou às escolas que aguardem as novas remessas de livros didáticos que serão enviados pelas editoras, que procurem em outras escolas da região e até mesmo na chamada reserva técnica. Já visitei algumas escolas, fui pessoalmente na reserva técnica e não encontrei livros suficientes que pudessem resolver o problema da falta de livro didático de inglês. Aguardarei mais um tempo, enquanto isso, tenho solicitado às mães que façam cópias do livro, pegando emprestado com os colegas que receberam. Cordialmente, T.L. Disponível em: < http://euzebiodiasbicalho.arteblog.com.br/418275/LIVRO-DIDATICO-E-O-TERMO-DE-

RESPONSABILIDADE/>. Acesso em: 10 e 13 mar. 2011.
} 
(os livros pré-aprovados) enquanto deslegitima outros e que deseja garantir as condições de sua produção, circulação e utilização em nossa sociedade. Esse controle já vinha sendo feito desde a adoção daquele que é considerado o primeiro livro para o ensino de inglês no Brasil (Grammatica pratica da Lingua Ingleza) em 1863. A gramática de Corrêa foi "approvada pelo Conselho Director d'Instrucção publica" ${ }^{146}$ antes de ser liberada para o uso em sala de aula. O controle sobre as obras aprovadas de muitas disciplinas escolares foi renovado e intensificado em 1945 e, em 2011, com o início da adoção nacional do LDI, ele se estende à disciplina de inglês. Para percebermos a importância dessa expansão, que agora abrange a disciplina de inglês, consideraremos, a seguir, algumas observações sobre a relação entre as disciplinas escolares e a sociedade.

\subsection{Disciplina e sociedade}

Para pensarmos no ensino de inglês como uma disciplina escolar, recorremos à noção de disciplina segundo André Chervel ${ }^{147}$ e suas observações sobre o uso desse termo no contexto escolar na França. Para ele, "A disciplina é aquilo que se ensina e ponto final" (CHERVEL, A., 1990, p. 177). Essa definição sucinta e conclusiva não surge, para Chervel, alheia à história; ao contrário, e como sugere o "ponto final", é precedida de um percurso histórico significativo.

Até antes do século XX, o uso do termo disciplina no contexto escolar refere-se ao controle e repressão das atitudes para a vigilância da "boa ordem"148 dos estabelecimentos escolares, como podemos ler nas "determinações estabelecidas pela Junta do Comércio de Portugal em 1767 acerca da disciplina e do comportamento necessário nas aulas de comércio" ${ }^{149}$ :

Alguns pontos remetem à necessidade de "decoro e silêncio", de não se demorar a entrar nas aulas, bem como na entrada e na saída. Caso o aluno tivesse muitas faltas ou cometesse "culpas de maior escândalo", como brigas, uso de navalhas, facas e "indecências", seria advertido ou até mesmo expulso.

O termo disciplina só será usado para designar conteúdo de ensino a partir das primeiras décadas do século XX. Já na segunda metade do século XIX, há um amplo esforço

\footnotetext{
${ }^{146}$ Voltaremos a esse dizer em 5.1.3.

${ }^{147}$ Professor de linguística e pesquisador, aposentado em 1983, permanece associado ao programa do Service à histoire de l'education - Institut National de Recherche Pédagogique, Paris, França.

${ }^{148}$ CHERVEL, A., 1990, p. 178.

149 Cf. <http://www.historiacolonial.arquivonacional.gov.br/cgi/cgilua.exe/sys/start.htm?infoid=749\&sid=96>. Acesso em: 25 fev. 2011.
} 
pedagógico de renovação dos objetivos do ensino escolar que aproxima o significado do verbo disciplinar ao exercício de "ginástica intelectual" ". A partir de 1850, a crise dos estudos de línguas clássicas, como o latim, pela ausência das respectivas culturas e de seus falantes nativos, traz consigo a noção de que esses estudos ainda se justificavam se tratados como exercícios para o desenvolvimento intelectual e espiritual do aluno. Em 1880, com a renovação pedagógica, a noção de disciplina como exercício intelectual passa a influenciar fundamentalmente a educação, propondo disciplinar a mente para desenvolver o julgamento, a razão, a combinação e a invenção ${ }^{151}$. Essa noção permanece até o fim da primeira Guerra Mundial, quando então o termo passa a ser o modo de se classificar e denominar as diferentes matérias escolares. Mesmo assim, como nos lembra Chervel, o verbo disciplinar produz, até nossos dias, o efeito de sentido de controle sobre a conduta. Diz André Chervel (1990, p. 180) sobre o termo disciplina:

\begin{abstract}
Mas, ainda que esteja enfraquecido na linguagem atual, ele não deixou de se conservar e trazer à língua um valor específico ao qual nós, queiramos ou não, fazemos inevitavelmente apelo quando o empregamos. [...] Além do mais, não tendo sido rompido o contato com o verbo disciplinar, o valor forte do termo está sempre disponível. Uma disciplina é, igualmente, para nós, em qualquer campo que se a encontre, um modo de disciplinar o espírito, quer dizer, de lhe dar os métodos e as regras para abordar os diferentes domínios do pensamento, do conhecimento e da arte.
\end{abstract}

O que se pode perceber através desse resumido percurso histórico do termo disciplina é exatamente a relação entre "aquilo que se ensina" e a sociedade; isto é, os conteúdos de ensino parecem ter sido sempre estabelecidos a partir da forte influência da sociedade. André Chervel afirma, ainda com mais segurança: "Estima-se ordinariamente, de fato, que os conteúdos de ensino são impostos como tais à escola pela sociedade que a rodeia e pela cultura na qual ela se banha"152. Assim, o trabalho duplo que o sistema escolar desempenha, formando indivíduos de acordo com os valores da sociedade e da cultura que esses mesmos indivíduos formarão, conta com aquilo que a sociedade estabelece como conteúdo das disciplinas. Há, com as transformações dos valores sociais, um movimento a ser considerado e, segundo Chervel ${ }^{153}$, "Nessas diversas evoluções, é a transformação do público escolar que obrigou a disciplina a se adaptar". A disciplina, então, é observada como a construção social

\footnotetext{
${ }^{150}$ CHERVEL, A., op. cit., p. 179.

151 Idem.

152 CHERVEL, A., op. cit., p. 179.

${ }^{153}$ Idem, p. 199.
} 
do "ensinável", que torna o ensino possível, pois, segundo Chervel (1990, p. 200), "Nesse processo de elaboração disciplinar, ela [a escola] tende a construir o 'ensinável'”.

Esse movimento circular atualiza-se em espiral a cada mudança no desenvolvimento dos indivíduos e da sociedade e, portanto, sem a fixação do "aquilo que se ensina", o "ponto final" na definição de Chervel pode ser entendido como reticências ${ }^{154}$. Não é possível, nem fecundo, portanto, determinar a origem das transformações. Apesar disso, sabe-se que esse processo acaba se concretizando nas finalidades das disciplinas, naquilo que elas estabilizam por certo período, e nas diretrizes que estabelecem essas finalidades. Segundo Chervel ${ }^{155}$,

Se é verdade que a sociedade impõe à escola suas finalidades, estando a cargo dessa última buscar naquela apoio para criar suas próprias disciplinas, há toda razão em se pensar que é ao redor dessas finalidades que se elaboram as políticas educacionais, os programas e os planos de estudo, e que se realizam a construção e a transformação históricas da escola.

Observamos, pois, que nessa relação de construção, transformação e sedimentação das políticas educacionais, ambas, sociedade e disciplina, se alimentam. Além disso, é nessa relação entre sociedade e escola que o "ensinável" é legitimado.

Nessa mesma relação, vemos inserido ainda o livro didático, como aquilo que materializa o "ensinável” já legitimado pela sociedade e pela escola. O “ensinável” legitimado representa, portanto, a verdade que o livro didático deve materializar. Como dissemos anteriormente, compreendemos verdade segundo a concepção foucaultiana: "Por 'verdade', entender um conjunto de procedimentos regulados para a produção, a lei, a repartição, a circulação e o funcionamento dos enunciados" (FOUCAULT, M., [1979] 2004, p.14). Portanto, a verdade, que Foucault equivale a saber, "não existe fora do poder ou sem poder" 156 e, ligada "circularmente" ao poder, ou a "sistemas de poder, que a produzem e apoiam, e a efeitos de poder que ela induz e que a reproduzem" ${ }^{157}$, constitui regimes de verdade, compostos por discursos de verdade. Passaremos, então, a discutir sobre o modo de funcionamento do LDI com um discurso de verdade.

\footnotetext{
${ }^{154}$ Essa interpretação nos permite discordar da crítica (como proposta por Bruno Belhoste, também pesquisador do Institut National de Recherche Pédagogique, Paris, França) ao caráter generalizador da argumentação de Chervel ao considerar que todos os saberes escolares estabeleceram-se de modo disciplinar em todas as épocas da história da educação; isso porque entendemos que a definição de Chervel não pressupõe obrigatoriamente a formalização institucional de "tudo aquilo que se ensina".

${ }^{155}$ CHERVEL, A., 1990, p. 219.

${ }^{156}$ FOUCAULT, M., [1979] 2004, p. 12.

${ }^{157}$ Ibidem, p. 14.
} 
$2.5 \mathrm{O}$ poder de discurso de verdade do livro didático

Historicamente, o sentido compartilhado socialmente sobre o poder do livro, como um lugar de saber, data de antes da metade do século XVIII, quando o estilo antigo de leitura se definia pela "reverência e respeito pelo livro porque ele é raro, porque está carregado de sacralidade mesmo quando é profano, porque ensina o essencial" (CHARTIER, R., [1945]1996, p. 86). Apesar de esse modo de leitura ter sido suplantado pela leitura volumosa, silenciosa e individual, com muitos textos laicos, a partir de $1750^{158}$, o poder do livro que ensina o essencial, e justamente por ensinar o essencial, parece ter sobrevivido ao tempo e marcado o livro didático desde o surgimento das primeiras cartilhas ou dos primeiros hornbooks $^{159}$. Além disso, o lugar da autoridade de saber, fruto dessa concentração da relação saber-poder, garante poder inquestionável ao livro didático e, assim, segundo Silva e Correia (2004, p. 616) "os educadores reconhecem que os impressos utilizados por alunos e professores permitem conhecer o cotidiano das salas de aula" justamente por apresentarem “conteúdos 'legítimos' a serem transmitidos” ${ }^{160}$ (APPLE, M. V., 1993, apud SILVA, V. B.; CORREIA, A. C., 2004 p. 617) já recortados, selecionados a partir do "patrimônio humano construído ao longo de gerações e ainda uma reelaboração dos tópicos escolhidos em nome de propósitos didáticos" 161 (FORQUIN, J., 1993, apud SILVA, V. B.; CORREIA, A. C., 2004, p. 617).

Além desse funcionamento do livro didático na condição de objeto de saber, é preciso considerar o modo de funcionamento de seu discurso. Para Grigoletto (1999), vários aspectos do LD apontam ao seu funcionamento como um discurso de verdade, ou um discurso que “ilusoriamente se estabelece como um lugar de completude dos sentidos"162. Diz a autora (GRIGOLETTO, M., 1999, p. 68):

O modo de funcionamento do LD como um discurso de verdade pode ser reconhecido em vários aspectos: no seu caráter homogeneizante, que é dado pelo efeito de uniformização provocado nos alunos (i.e., todos são levados a fazer a mesma leitura, a chegar às mesmas conclusões, a reagir de uma única forma às propostas do manual); na repetição de uma estrutura comum a todas as unidades, com tipos de seções e de exercícios que se mantêm constantes por todo o livro, fator que contribui para o efeito de

\footnotetext{
${ }^{158}$ CHARTIER, R., [1945]1996, p. 86.

${ }^{159}$ Nome em inglês da cartilha feita de madeira, couro e chifre, usada durante vários séculos, a partir de meados do século XV, na Europa e nos Estados Unidos da América.

${ }_{160}$ APPLE, M. Trabalho docente e textos: economia política das relações de classe e de gênero em educação. Porto Alegre: Ed. Artes Médicas, 1995.

${ }^{161}$ FORQUIN, J-C. Escola e cultura: as bases sociais e epistemológicas do conhecimento escolar. Porto Alegre: Artes Médicas, 1993.

${ }^{162}$ GRIGOLETTO, M., 1999, p. 67-68.
} 
uniformização nas reações dos educandos; e na apresentação das formas e dos conteúdos como naturais, criando-se o efeito de um discurso cuja verdade "já está lá", na sua concepção.

Também Souza (1999, p. 27) trata do poder de verdade do livro didático, relacionando tal poder ao saber que ele encerra:

O caráter de autoridade do livro didático encontra sua legitimidade na crença de que ele é depositário de um saber a ser decifrado, pois supõe-se que o livro didático contenha uma verdade sacramentada a ser transmitida e compartilhada. Verdade já dada que o professor, legitimado e institucionalmente autorizado a manejar o livro didático, deve apenas reproduzir, cabendo ao aluno assimilá-la.

Isto é, o livro didático carrega em suas páginas, através de seu “caráter homogeneizante", como descrito acima por Grigoletto, a "verdade sacramentada" que, de acordo com Souza, também acima, deve ser transmitida e reproduzida pelo profissional autorizado institucionalmente, portanto legitimado, a fazê-lo. Nesse momento da sala de aula, vemos a necessária participação do professor no processo de legitimação do saber digitado, linearizado, estruturado, simplificado, homogeneizado, ilustrado e diagramado nas páginas do livro didático. Um saber morto que espera, aguarda, e que só será posto em circulação pela ação do professor. Um saber que necessita de uma carga de poder que se lhe incida para pô-lo em funcionamento como verdade, como na concepção foucaultiana em que o poder tem a incumbência de produzir a verdade.

Essa necessária participação daquele que coloca o saber do livro didático a funcionar como verdade pode se instaurar como um momento de escape e, no caso do professor, o lugar da resistência. É preciso, contudo, não menosprezar a força da vontade por uma ação didática apenas reprodutora, como encontramos nas prescrições detalhadas nos manuais, ou livros do professor, sobre o uso do LDI. Aliás, como lembra Grigoletto (1999, p. 76), "Por sua própria concepção, o manual [do professor] induz a que se delineiem papéis fixos, padronizados, regidos pela disciplina da homogeneização, da repetição e do caminho já estabelecido por outras mãos".

Mesmo assim, não podemos deixar de perceber nesse momento, em que o saber nas páginas do livro didático aguarda a voz que o transformará em verdade, o espaço da ação docente - que, como obra do ser que age, pode não ser apenas reprodutora - e também a contribuição do discurso sobre o LDI, que pode ou não atribuir ao livro didático o poder 
necessário para produzi-lo como verdade. Afinal, como argumentam Deacon e Parker (1995, p.102),

[...] aquilo que aparece como mecanismo para a transmissão do conhecimento por uma autoridade, dentro de uma instituição, representa, na realidade, condições de possibilidade de sujeição, mascarada por alegações de favorecimento do progresso intelectual, da mobilidade sócio-econômica e do progresso social.

Tais "possibilidades de sujeição" devem ser consideradas, esclarecem os autores, dentro de uma microfísica do poder, como na concepção foucaultiana sobre a circulação do poder, e não no sentido de mão única da dominação.

Ainda segundo Foucault, não há verdade que se faça sem poder e, do mesmo modo, o poder não deve ser entendido como algo que se possui, pois ele circula: "para que haja um movimento de cima para baixo, é preciso que haja ao mesmo tempo uma capilaridade de baixo para cima" (FOUCAULT, M., [1979] 2004, p. 250). Tal como a verdade, o poder não deve ser entendido como algo que se possa produzir fora de sua relação com o saber. São essas as motivações que nos levam a crer que o livro didático não pode funcionar como um discurso de verdade sem a contribuição do discurso sobre ele; visto que o saber que ele encerra necessita de investimentos de poder para circular e, assim, se colocar como verdade. Acreditamos, portanto, que o discurso sobre o LDI investe poder sobre o saber do LDI para que ele possa funcionar como um discurso de verdade. Portanto, lançaremos agora um olhar mais incidente sobre a relação entre o discurso sobre o livro didático de inglês e o discurso de verdade.

\subsection{Discurso de verdade e o discurso sobre o LDI}

Antes que possamos tecer nossas observações sobre o modo de funcionamento do discurso de verdade em relação ao discurso sobre o LDI, deveremos retomar alguns conceitos relevantes para esta discussão.

Para a Análise do Discurso de linha pecheutiana, não é possível tratar do discurso sem observar o sujeito, já que ambos se constituem concomitantemente e um se define pelo outro. Essa linha de pesquisa considera, pois, as definições de discurso como dispersão do sujeito e de sujeito como efeito do discurso. Nessa relação, o indivíduo interpelado pela ideologia ${ }^{163} \mathrm{e}$ atravessado pelo inconsciente se dispersa em discurso. Portanto, apesar de nossa pesquisa ter

${ }^{163}$ PÊCHEUX, M., [1975] 2009, p. 141. 
o foco mais acentuado no discurso, não há como não considerar, em momentos específicos deste trabalho, o sujeito que nele se dispersa e se constitui. Nessa dupla constituição, do sujeito e do discurso, a alteridade, como a presença do outro, é fundamental para entendermos aquilo que caracteriza o sujeito como cindido, fragmentado e incompleto, e aquilo que faz com que todo discurso seja heterogêneo. Trataremos, primeiramente, sobre a heterogeneidade do discurso. A seguir, faremos algumas considerações sobre o discurso de verdade e, finalmente, trataremos do discurso sobre o LDI.

\subsubsection{Heterogeneidade discursiva}

A $\mathrm{AD}$ difere heterogeneidade de diversidade. Enquanto a noção de diversidade é compreendida como variedade ou multiplicidade, "como um conjunto de indivíduos ou de características individuais" (CORACINI, M. J., 2003, p.255), a heterogeneidade é percebida como a presença do outro já na constituição do sujeito e do dizer, produzindo-os, desde sempre, fragmentados pelo atravessamento dessa alteridade. Por isso, para a AD, todo discurso é heterogêneo.

A constitutividade da heterogeneidade pode ser também entendida a partir dos dois esquecimentos postulados por Michel Pêcheux ${ }^{164}$. Na dispersão do discurso, o esquecimento número um garante a ilusão de o sujeito ser a origem de seu dizer, enquanto o de número dois ilude o sujeito sobre a unicidade de sentido de seu dizer. Esses esquecimentos e ilusões sobre a não participação do outro na constituição do sujeito e do discurso são necessários para que o indivíduo afetado pela ideologia e pelo inconsciente se disperse em discurso. Há, portanto, a ilusão necessária de homogeneidade - UM, no sentido de Authier-Revuz ${ }^{165}$ - que mantém o sujeito imaginariamente na origem, na unicidade, intencionalidade e transparência de seu dizer. Essa concepção de unidade imaginária demanda que o sujeito recalque, no momento do discurso, sua inserção na história, na língua e na ideologia, para se dispersar em discurso, voltando-se a esses territórios apenas nos instantes em que o inconsciente se lhe imponha, como acontece em atos falhos, ou ainda quando o sujeito percebe seu dizer ameaçado pela não-coincidência e procura negociar o sentido desse seu dizer. Diz Authier-Revuz (AUTHIER-REVUZ, J., [1982] 2004, p. 85-86),

[...] a negociação obrigatória de qualquer enunciador com o fato das nãocoincidências que afetam irredutivelmente seu dizer: negociação que consiste em reconhecer, nesse dizer, o jogo do não-um, mas ao modo da

\footnotetext{
${ }^{164}$ PÊCHEUX, M., [1975] 2009, p. 160-161.

${ }^{165}$ AUTHIER-REVUZ, J., 1990, 2001 e 2004.
} 
denegação, pela representação que dele é dada - a de um acidente, uma falha local, preservando e até reafirmando assim, nos próprios lugares em que ele é questionado, o fantasma de coincidência, de UM, necessário ao sujeito falante.

Observamos, a partir daí, que, apesar do caráter antinômico dos termos, homogeneidade e heterogeneidade não são, por assim dizer, conceitos opostos. Isso porque o estatuto de ilusão do conceito de homogeneidade delimita um espaço diferente daquele em que circula o conceito de heterogeneidade. Não se pode conceber, para ilustrar, os termos ocupando lados extremos, como uma cabeça de Jano ${ }^{166}$ em que um lado seja o oposto do outro, nem se configurando como dois polos separados pelo sentido antitético, uma vez que o polo da homogeneidade estaria apenas ilusoriamente ocupado. Mesmo que indomável e, muitas vezes, não localizável, a heterogeneidade pode ser percebida na constituição singular de cada coisa e de cada ser, como aquilo que escapa a toda contenção de homogeneização. Por sua vez, a homogeneidade não pode ser representada sem a presença da heterogeneidade já a deslegitimá-la, sendo o não-um constitutivo do Um ${ }^{167}$. Também, para Coracini (2003, p.265),

Estamos defendendo a consideração da heterogeneidade, não como o outro lado da polarização, mas como constitutiva do sujeito e do dizer em conflito permanente com o desejo da homogeneização, da perfeição, da unicidade. Se não é possível apagar esse desejo, também não é possível apagar a heterogeneidade constitutiva, que torna complexo o que parece simples, múltiplo, o que parece uno, conflitante, o que parece controlável pela razão ou pela ciência.

Portanto, devido à constitutividade do não-um já no UM, o sentido antitético entre homogeneidade e heterogeneidade não se configura como uma simples relação de oposição.

A relevância dessa discussão para o trabalho que estamos desenvolvendo se relaciona à heterogeneidade discursiva, como atravessamentos discursivos, que se pode observar no discurso sobre o livro didático de inglês. O discurso sobre o LDI parece estar, de algum modo, um tanto mais receptível à heterogeneidade discursiva, ou menos desejante de homogeneização. Isso porque é comum que, nos dizeres do discurso sobre o LDI, o sujeito enunciador, ao falar sobre seu objeto, teça considerações sobre um outro que se encontra em

\footnotetext{
${ }^{166}$ Jano, o porteiro celestial, é o deus romano dos portões e entradas, representado com uma cabeça composta por duas faces que olham em direções opostas, Algumas concepções associadas à simbologia suscitada pela cabeça de Jano são: o começo e o fim, o dentro e o fora, o passado e o futuro. Na psicanálise, a cabeça de Jano é relacionada à questão do duplo (realidade/fantasia, consciente/inconsciente etc.), à noção freudiana dos pares antitéticos e à divisão do sujeito psicanalítico (cf. JORGE, M.A.C., 2002).

${ }^{167}$ Sobre a constitutividade do não-um, veja AUTHIER-REVUZ, 1990, 2001 e 2004.
} 
outro lugar, tempo ou condição diferente da que ocupa o sujeito enunciador. Sobre isso, vemos que, no discurso profissional, as respostas dos professores frequentemente têm o aluno, a aula, o ensino etc., e não exatamente o LDI, como objeto ${ }^{168}$. No discurso oficial, observamos os discursos administrativo e jurídico imbricados no discurso políticoeducacional $^{169}$. O discurso midiático se impregna do discurso oficial ao reproduzi-lo integralmente ${ }^{170}$.

Ainda sobre a ilusão de homogeneidade discursiva, entendemos, com a $\mathrm{AD}$, que existem ordens do discurso que, em estreita relação com o âmbito das formações ideológicas e discursivas ${ }^{171}$ que as circunscrevem, delineiam a interpretação, sem conterem o sentido. Diz Orlandi (2007, p. 138):

Certamente, há diferentes ordens de discurso - científico, religioso, jurídico, etc. - havendo assim diferentes modos de interpretação. Mas há sempre interpretação. Ainda quando há interdição de interpretação, há espaço de trabalho do sujeito e da história na relação com os sentidos.

Uma ordem do discurso compreende ou abrange certo número de formações discursivas que atribuem sentido, interpretam o mundo. Sendo as formações discursivas heterogêneas em si e cada ordem do discurso abrangendo várias formações discursivas, uma ordem do discurso é, consequentemente, heterogênea. Porém, não se pode dizer que não haja, em uma ordem do discurso, a vontade de controle sobre os dizeres. Ao contrário, as formações discursivas e ideológicas marcam os limites do sentido e da interpretação. Sobre esse controle da ordem do discurso, disse Foucault ([1970] 2004, p. 36-37):

[...] trata-se de determinar as condições de seu funcionamento [dos discursos], de impor aos indivíduos que os pronunciam certo número de regras e assim de não permitir que todo mundo tenha acesso a eles. Rarefação, desta vez, dos sujeitos que falam; ninguém entrará na ordem do discurso se não satisfizer a certas exigências ou se não for, de início, qualificado para fazê-lo.

Aquilo que nos leva muitas vezes, como analistas do discurso, à tentação de classificar "tipos" de discurso, como uma medida prática de nomearmos as ordens em que o discurso se

\footnotetext{
${ }^{168}$ Cf. P4Q2, P9Q1 e P8Q2, entre outros.

${ }^{169}$ Cf. Capítulo 6, item 6.1, S49.

${ }^{170}$ Cf. Capítulo 4, item 4.3, S11 e S12, entre outras.

${ }^{171}$ PÊCHEUX, M., [1975] 2009, p. 147: "Chamaremos, então, formação discursiva aquilo que, numa formação ideológica dada, isto é, a partir de uma posição dada numa conjuntura dada, determinada pelo estado da luta de classes, determina o que pode e deve ser dito [...].
} 
faz como acontecimento, pode desnecessariamente produzir o efeito de estabilização e homogeneidade, gerando certo clima de incompatibilidade teórica. Acreditamos, portanto, na necessidade de sempre marcarmos a presença do outro. Essa questão é já muito discutida e também envolve outros conceitos de $\mathrm{AD}$, como o conceito de formação discursiva. Isto é, desde Pêcheux ${ }^{172}$, observamos que certa posição de sujeito - ou a posição que o sujeito ocupa no discurso, inscrita em formações ideológicas - é já um lugar marcado pelas formações discursivas. Segundo Michel Pêcheux ${ }^{173}$, “a interpelação do indivíduo em sujeito de seu discurso se efetua pela identificação (do sujeito) com a formação discursiva que o domina (isto é, na qual ele é constituído como sujeito)”.

Nesse mesmo texto, Pêcheux fala de formações discursivas, no plural, mas é enfático em dizer que há uma formação discursiva dominante. Ora, se há uma dominante é porque, no mesmo lugar de disputa, há outras; daí a necessidade de se dizer "dominante". Porém, o termo "dominante" pode produzir o efeito indesejável de estabilização de poder mais facilmente do que produzir o efeito de luta. Sendo assim, aderimos ao uso do adjetivo "preponderante", como trabalhado por Serrani ${ }^{174}$ (1997), para observar a relação entre as formações discursivas que marcam o lugar de onde o sujeito fala e, é preciso dizer, com Pêcheux ${ }^{175}$, lugar de constituição do sentido.

Acreditamos que esse funcionamento sobre o qual falamos é o efeito de evidência de dominância de uma formação discursiva sobre outras ou de um discurso sobre outros. Como argumentamos, não acreditamos que haja uma formação discursiva "dominante" que possa neutralizar outras, ou um tipo ou ordem do discurso que neutralizasse outras, evidenciando-se, assim, certa homogeneidade. Talvez, esse funcionamento que faz com que um discurso, ou uma formação discursiva, seja mais perceptível, esmaecendo outros/as, possa ser considerado como efeito de preponderância, ou envolto em "relações de preponderância"176, como no caso de uma formação discursiva sobressair-se em detrimento de outras. Percebemos, então, um discurso preponderante em relação a outros, ou ainda, uma ordem do discurso preponderante em relação a outras etc.. Isso não significa, para a $\mathrm{AD}$, que o sentido, em seu inevitável deslizamento, será de todo modo contido; pois, aquilo que é preponderante é, em certa

\footnotetext{
${ }_{172}^{172}$ PÊCHEUX, M., [1975] 2009.

173 Ibidem, p. 150.

174 SERRANI, S. Formações discursivas e processos identificatórios na aquisição de línguas. In: Delta, vol. 13, $\mathrm{n}^{\circ} \quad 1, \quad$ 1997. $\quad$ Disponível em: $\quad$ http://www.scielo.br/scielo.php?pid=S010244501997000100004\&script=sci_arttext $>$. Acesso em: $01 \mathrm{dez} 2013$.

${ }^{175}$ PÊCHEUX, M., [1975] 2009, p. 147-148.

176 SERRANI, S. (1997).
} 
medida, mais importante, superior; o que não se aplica necessariamente ao discurso preponderante, ou àquele que se sobressai aos demais.

A seguir, trataremos das teorizações acerca do discurso de verdade, conforme estabelecido por Michel Foucault, para balizarmos nossa análise dos dizeres do discurso sobre o LDI na segunda parte deste trabalho.

\subsubsection{Discurso de verdade}

Em seu texto Verdade e Poder, elaborado a partir de uma entrevista a Alexandre Fontana e publicado em Microfísica do poder, Michel Foucault define verdade: "Por 'verdade', entender um conjunto de procedimentos regulados para a produção, a lei, a repartição, a circulação e o funcionamento dos enunciados" (FOUCAULT, M., [1979] 2004, p.14). Portanto, a verdade, que em Foucault equivale a saber, "não existe fora do poder ou sem poder" 177 e, ligada "circularmente" ao poder, ou a "sistemas de poder, que a produzem e apoiam, e a efeitos de poder que ela induz e que a reproduzem" ${ }^{178}$, constitui regimes de verdade, compostos por discursos de verdade. Disse Foucault ${ }^{179}$ :

Cada sociedade tem seu regime de verdade, sua "política geral" de verdade: isto é, os tipos de discurso que ela acolhe e faz funcionar como verdadeiros; os mecanismos e as instâncias que permitem distinguir os enunciados verdadeiros dos falsos, a maneira como se sanciona uns e outros; as técnicas e os procedimentos que são valorizados para a obtenção da verdade; o estatuto daqueles que têm o encargo de dizer o que funciona como verdadeiro.

Comentando sobre essa mesma citação em que Foucault define discurso de verdade, Jennifer M. Gore ([1994] 1995, p. 10) conclui que todo discurso é discurso de verdade:

Se o poder e a verdade estão "ligados numa relação circular", se a verdade existe numa relação de poder e o poder opera em conexão com a verdade, então todos os discursos podem ser vistos funcionando como regimes de verdade.

Vemos que a afirmação de que todo discurso funciona como discurso de verdade produz necessariamente pelo menos duas implicações: a garantia da não intencionalidade do dizer - ou da distância entre a motivação do dizer e seus efeitos - e da não unicidade de sentido - ou de que a verdade nada mais é do que um efeito - já que um discurso e seu

\footnotetext{
${ }^{177}$ FOUCAULT, M., [1979] 2004, p.12.

178 Ibidem, p. 14.

${ }^{179}$ Ibidem, p. 12.
} 
contrário não produzem, ao mesmo tempo e para uma mesma formação discursiva, o mesmo efeito de verdade, nem o mesmo sentido. Ainda aqui, vemos a verdade como um saber, de acordo com a concepção foucaultiana do termo na relação saber-poder.

É preciso ainda lembrar que Foucault não atribuiu valores só positivos ou negativos ao poder, nem ao saber. Para Foucault ${ }^{180}$,

O que faz com que o poder se mantenha e que seja aceito é simplesmente que ele não pesa só como uma força que diz não, mas que de fato ele permeia, produz coisas, induz ao prazer, forma saber, produz discurso. Devese considerá-lo como uma rede produtiva que atravessa todo o corpo social muito mais do que uma instância negativa que tem por função reprimir.

Além disso - e essa é uma questão muito pertinente ao nosso trabalho - Foucault ([1982] 1995, p. 243) afirma que o poder só existe quando colocado em ação ${ }^{181}$ e define ${ }^{182}$, assim, o poder como um conjunto de ações sobre outras ações; ou ainda,

De fato, aquilo que define uma relação de poder é um modo de ação que não age direta e imediatamente sobre os outros, mas que age sobre sua própria ação. Uma ação sobre a ação, sobre ações eventuais, ou atuais, futuras ou presentes.

Analogamente, acreditamos que o discurso sobre o livro didático de inglês coloca em ação o discurso desse livro didático, fazendo com que ele funcione como um discurso de verdade. Portanto, acreditamos que tal funcionamento pode se configurar como um conjunto de ações sobre outras ações ${ }^{183}$.

\subsubsection{O discurso sobre $\mathrm{X}^{184}$}

Do mesmo modo que todo discurso pode funcionar como discurso de verdade, como concluído por Gore ${ }^{185}$ e mencionado no item anterior, todo discurso é, de alguma maneira, um discurso sobre algo ou alguém na medida em que todo discurso fala sobre alguma coisa ou pessoa. Mesmo assim, percebemos algumas diferenças nos funcionamentos do discurso de $\mathrm{X}$ e do discurso sobre $\mathrm{X}$, considerados, aqui, como duas categorias discursivas que apresentam uma relação de implicação e, ao mesmo tempo, mantêm certo distanciamento.

\footnotetext{
${ }^{180}$ FOUCAULT, M., [1979] 2004, p. 8.

${ }^{181}$ No texto originalmente escrito em inglês, FOUCAULT, M. (1982, p. 219) diz: "Power exists only when it is put into action",

${ }^{182}$ FOUCAULT, M., 1982, p. 220, diz: "A set of actions upon other actions".

${ }^{183}$ Como formulado na versão em inglês (FOUCAULT, M., 1982, p. 220): “A set of actions upon other actions".

${ }^{184}$ Usamos aqui o X para não restringir nossa argumentação apenas ao discurso sobre o livro didático de inglês.

${ }^{185}$ GORE, J., [1994] 1995.
} 
Nossa observação inicial é que o discurso do livro didático de inglês (discurso de $\mathrm{X}$ ) é percebido materializado, como texto, com elementos linguísticos e não linguísticos, nas páginas do LDI e discorre sobre a língua e sobre os mais variados assuntos, com propósitos explicitamente didáticos, ou ainda, preponderantemente didáticos. Já o objeto do discurso sobre o livro didático de inglês (discurso sobre $\mathrm{X}$ ) é o próprio LDI tomado como um instrumento de ação didática. Portanto, é possível afirmar que o discurso de X (do LDI) funciona no discurso sobre X (sobre o LDI) como um pré-construído. Antes de tecermos outras considerações, gostaríamos de comentar as contribuições de alguns teóricos a esse respeito.

Para Bourdieu (1990, p.134), "muitos discursos sobre o objeto na verdade não passam de projeções da relação objetiva do sujeito com o objeto". Essa observação nos leva a pensar nas representações do LDI para aquele que o tem como objeto. Se a análise do discurso de professores de língua observa como são construídas as representações de aluno, língua, aula, livro didático etc., nessa perspectiva, o discurso sobre o LDI pode ser considerado como um recorte, um olhar mais direcionado ao objeto do discurso do LDI. Assim, argumentamos que estudar o discurso sobre o LDI é perceber os efeitos de sentido dos dizeres daquele que tem o LDI como seu objeto.

A análise do discurso sobre $\mathrm{X}$ observa a ilusão do sujeito que, ao falar sobre seu objeto, crê não falar sobre si ou sobre o outro não contemplado por esse X. Isto é, em seu discurso sobre o LDI, o sujeito enunciador constrói representações que não se restringem ao LDI, mas que contemplam também o professor, o aluno, a língua, o ensino de línguas, a aula etc.

Em relação ao analista, diríamos que aquele que olha o livro didático de inglês, seu objeto, o interpreta. Aquele que olha quem olha o livro didático preocupa-se em perceber como esse material está sendo interpretado pelo sujeito. Essa segunda posição é a que desejamos ocupar no momento da análise.

De todo o modo, as teorizações especificamente relativas ao discurso sobre $\mathrm{X}$ são escassas. Bethania Mariani, em seu livro O PCB e a imprensa (MARIANI, B., 1998), define o discurso sobre $\mathrm{X}$, dizendo que esse discurso "atua no efeito de linearidade e homogeneidade da memória". A partir daí, podemos entender que, ao produzir o efeito de que a história é linear e homogênea, o discurso sobre $\mathrm{X}$ apaga a complexidade de funcionamento e a heterogeneidade constitutiva de todo discurso. Esses apagamentos assumem uma dimensão importante se pensarmos que o que fica apagado pela linearização e homogeneização da memória é justamente aquilo que é considerado, pelo discurso sobre $\mathrm{X}$, como historicamente 
secundário e menos relevante. Portanto, o discurso sobre $\mathrm{X}$ elege aquilo que será parte da memória em detrimento de outros elementos que ficam apagados e fora da história. Sobre o discurso sobre X, Mariani (1999, p. 60) ainda acrescenta:

De modo geral, representa lugares de autoridade em que se efetua algum tipo de transmissão do conhecimento, já que o falar sobre transita na co-relação entre o narrar/descrever um acontecimento singular estabelecendo sua relação com um campo de saberes já reconhecido pelo interlocutor.

Esses "lugares de autoridade" que o discurso sobre X representa, como lemos na citação acima, são ocupados pelos sujeitos que elegem o que deve ou não ser revitalizado pelo discurso, reproduzindo esse conhecimento como forma de verdade. Ou seja, a voz da autoridade que fala no sujeito enunciador do discurso sobre X se apresenta com poder e saber, mesmo que não seja formalmente investida desse poder. Entre a narração e a descrição, que caracterizam o discurso sobre $\mathrm{X}$, são tecidas as relações de saber-poder através de saberes compartilhados entre o sujeito e o interlocutor.

$\mathrm{O}$ efeito de voz de autoridade rende ao sujeito enunciador do discurso sobre $\mathrm{X}$ a posição de poder produzida por seu saber e que, ao mesmo tempo, produz saber: a verdade. Não necessariamente, aquele que é chamado para falar sobre algo ocupa um lugar construído por formações discursivas que já lhe outorgam o poder que seu saber conquistou. Esse poder, no entanto, é produzido, ou se já se exerce, é ainda reforçado, pelo efeito de voz de autoridade do discurso sobre $\mathrm{X}$, a voz daquele que transmitirá o conhecimento.

Ao discutir sobre o "olhar do livro didático", Coracini (2003, p. 200) afirma que "o discurso didático, como todo discurso pedagógico, apresenta-se como sendo a verdade”. Esse efeito de sentido, diz a autora, provém da "apresentação do conteúdo e da diagramação do texto [...] nos livros didáticos de língua estrangeira" e "talvez sobretudo, de uma certa visão de cientificidade que atravessa o discurso pedagógico". Essa mesma cientificidade, acreditamos, atravessa também o discurso sobre o LDI, produzido pelo sujeito que fala da posição de especialista, que, como argumentamos acima, é produzido ou reforçado pelo efeito de voz de autoridade do discurso sobre X.

Essa parece ser, acreditamos, outra especificidade do discurso sobre $X$; isto é, enquanto o sujeito do discurso de $\mathrm{X}$ assume a formação discursiva que lhe é própria, costumeira e, de certo modo, conhecida e reconhecida por ele e por seu interlocutor, aquele que é chamado a ser sujeito do discurso sobre $\mathrm{X}$ assume a posição de especialista, um lugar de autoridade, que lhe rende o efeito de voz de autoridade e "visão de cientificidade". Mesmo 
assim, Orlandi (2007, p. 139), ao afirmar que nem mesmo o discurso científico está fora da ideologia e, portanto, é também interpretação, observa que "há várias posições do sujeito cientista. A opção por uma linha teórica (científica) ou outra distingue-as". Portanto, mesmo os dizeres do sujeito enunciador do discurso sobre $\mathrm{X}$, com seus efeitos de verdade, de saber, são gestos de interpretação atravessados pela ideologia.

\subsection{Discurso e sociedade de controle}

Como lembramos na introdução deste trabalho, o conceito pecheutiano de discurso é definido como estrutura e acontecimento. Trataremos, pois, dos conceitos de estrutura e de acontecimento, formadores do conceito de discurso, a seguir e, então, da noção de sociedade de controle. A partir daí, traçaremos algumas relações entre discurso e sociedade de controle, que contribuem ao desenvolvimento da análise dos dizeres do corpus.

Pêcheux ([1983] 2002, p. 17) define acontecimento como aquilo que se dá "no ponto de encontro de uma atualidade e uma memória”. Portanto, o acontecimento não pode ser, para a $\mathrm{AD}$, concebido fora do contexto histórico em que amplamente se insere. Ao contrário, ambos, o presente, como atualidade, e o passado, como memória, se reproduzem em enunciados que marcam um momento. Também para Guilhaumou e Maldidier ([1986], 2010, p. 164),

O acontecimento discursivo não se confunde nem com a notícia, nem com o fato designado pelo poder, nem mesmo com o acontecimento construído pelo historiador. Ele é apreendido na consistência de enunciados que se entrecruzam em um momento dado.

Depreende-se, daí, que tal "consistência de enunciados" que possibilita a apreensão do acontecimento só pode ser percebida na materialidade do processo discursivo ${ }^{186}$. Mais especificamente, busca-se a percepção daquilo que do acontecimento incide na materialidade linguística estruturada a partir do sistema de regras da língua como condição de discurso. A noção de estrutura, portanto, ultrapassa o âmbito da linguística que considera a língua como um sistema de regras, e marca pontos de funcionamento da história e da ideologia.

Do mesmo modo que o discursivo é considerado como um processo, assim também o são a história (por seu movimento) e a ideologia (práticas), considerando-se que nem uma

186 Cf. PÊCHEUX, M. ([1975] 2009, p. 148), o processo discursivo designa “o sistema de relações de substituição, paráfrases, sinonímias etc., que funcionam entre elementos linguísticos - 'significantes' - em uma formação discursiva dada". 
nem outra são estanques no tempo e restritas a espaços. Mesmo assim, os processos históricoideológicos acolhem enunciados que marcam uma sociedade, caracterizando-a predominantemente - mas não de todo homogeneamente - como um "tipo" de sociedade. Ao admitirmos essa relação entre discurso e sociedade, devemos observar que o discurso de cada sociedade traz em si as marcas linguísticas de seu tempo. Sobre isso, lembramos que a AD relaciona à sociedade de cada época uma forma-sujeito histórica. Tratando sobre a noção de determinação em relação à constituição do sujeito, Claudine Haroche ([1984] 1992, p. 179) relaciona a forma sujeito-religioso à Idade Média e a forma sujeito-jurídico (com direitos e deveres) à Idade Moderna e afirma: "Se podemos colocar na história a referência para a gênese da noção de sujeito-de-direito, também a noção de sujeito, que deriva em grande parte da ideologia, pode-se esclarecer por uma análise histórica".

Considerando, a partir da citação acima, que a noção de sujeito deriva da ideologia e se esclarece pela história, podemos supor que a forma-sujeito histórica de hoje apresenta já alguns deslocamentos em relação àquela comumente associada à Idade Moderna. Isso porque aquilo que está em jogo na relação entre discurso e sociedade trata especificamente da conjunção entre sujeito, sentido - como efeitos do discurso - e formas de poder e saber, como o modo de funcionamento da sociedade. Podemos pensar essa conjunção a partir das conceitualizações de Orlandi ([2001] 2008, p. 104-9), sintetizadas no esquema proposto por ela à página 106 que reproduzimos abaixo:

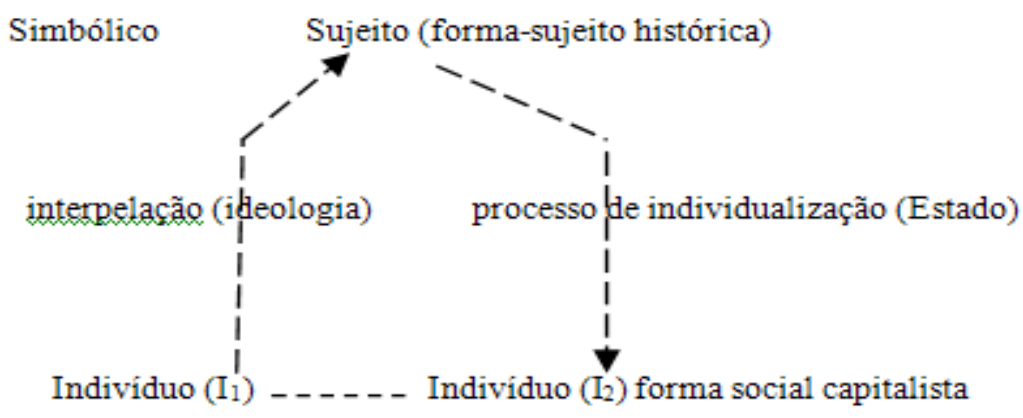

(bio, psico) (social)

Fig. 3 - Forma-sujeito histórica (ORLANDI, E., [2001], 2008, p. 106)

Segundo Orlandi, o indivíduo em primeiro grau $\left(\mathrm{I}_{1}\right)$, um ser "bio e psico", é interpelado ideologicamente ao ser afetado pelo Simbólico, isto é, ao se identificar às 
representações produzidas pela ideologia e pela história, tornando-se sujeito. Orlandi explica que é a interpelação ideológica que constituirá a forma-sujeito histórica. Estando constituída, a forma-sujeito é agora individualizada pelo Estado, com suas instituições e formações sociais. A individualização da forma-sujeito histórica produz efeitos diferentes que repercutem tanto nos processos de identificação do sujeito quanto em sua produção de sentido. Como resultado desse percurso, temos o indivíduo em segundo grau $\left(\mathrm{I}_{2}\right)$, uma construção que deve responder à sociedade de acordo com os próprios parâmetros pelos quais ele, na condição de sujeito (forma-sujeito histórica) fora individualizado. Nas palavras de Orlandi ([2001] 2008, p. 107),

Uma vez interpelado em sujeito, pela ideologia, em um processo simbólico, o indivíduo, agora enquanto sujeito, determina-se pelo modo como, na história, terá sua forma individual(izada) concreta: no caso do capitalismo, que é o caso presente, a forma de um indivíduo livre de coerções e responsável, que deve assim responder, como sujeito jurídico (sujeito de direitos e deveres), frente ao Estado e aos outros homens.

Vemos, portanto, a importante relação entre o funcionamento da sociedade e o modo de constituição do sujeito e do discurso. Ressaltamos, ainda, que a história é o elemento que, junto com a ideologia, atualiza o modo de subjetivação em cada sociedade e em cada época, pois, ainda segundo Orlandi ([2001] 2008, p. 104),

Como a injunção à interpretação tem suas formas e condições, ela não se dá da mesma maneira nos diferentes momentos da história. A determinação histórica na constituição dos sentidos e dos sujeitos tem uma forma material concreta distinta nas diferentes formas sociais.

Daí a importância de investigarmos o modo de funcionamento da sociedade atual. Para tanto, é preciso admitir o caráter heterogêneo desse funcionamento; isto é, não se pode assumir que todos os indivíduos de uma dada época histórica sejam interpelados em sujeitos do mesmo modo, ao mesmo tempo e que a interpelação ideológica funcione sempre muito bem e homogeneamente. Por outro lado, é preciso também admitir que a ideologia trabalha no sentido de nivelar as diferenças, apagando ilusoriamente a contradição. Assim, trataremos, a seguir, de caracterizar o modo de funcionamento da chamada sociedade de controle, aproximando-o ao funcionamento de nossa sociedade atual. 
Retomando alguns dos principais aspectos relacionados à sociedade disciplinar já mencionados na introdução deste trabalho, lembramos que, de acordo com Foucault ${ }^{187}$, desde o século XVII, e com mais vigor no século XVIII, a disciplina caracterizou o modo de funcionamento da sociedade, organizando seu tempo e espaço.

Em relação ao tempo e à circulação do poder, segundo Foucault ([1975] 2004, p. 136), na sociedade disciplinar, o poder se articulava sobre o tempo, controlando-o e garantindo sua utilização. Hoje, também o tempo deixa de ser percebido como fixo, regular e constante. Trabalhamos em horários flexíveis (flexitime) e temos banco de horas, para registro de horas trabalhadas a mais ou a menos que serão compensadas, evitando alterações na folha de pagamento. Muitos feriados são também compensados, tendo suas datas historicamente fixadas transferidas no tempo para a adequação da semana de trabalho. Nossas compras podem ser feitas em hipermercados abertos a noite toda ou também a qualquer hora pela internet. Há bancos vinte e quatro e até trinta horas. Fazemos reuniões e conferências internacionais em tempo real sem sair do escritório.

Em relação ao espaço, os métodos da sociedade disciplinar eram exercitados nos locais fechados (colégios, hospitais, quartéis, fábricas etc.), em que se aplicava o princípio do “quadriculamento individualizante" (FOUCAULT, M., [1975] 2004, p. 124). Esse princípio isolava, localizava e distribuía os corpos, organizando e dividindo o espaço, com o mesmo objetivo de tornar os corpos mais obedientes e mais úteis. Além disso, como apontado por Deleuze ([1990] 2008), o poder que caracteriza uma sociedade disciplinar circula entre os módulos criados pelas instituições que a constituem: a fábrica, o hospital, a escola, a prisão etc. Porém, ainda como argumenta o autor (DELEUZE, G., [1990] 2008), com o advento da globalização, da comunicação em rede, o enfraquecimento das bordas que delimitam esses espaços fechados e repartidos pela sociedade disciplinar favorece a circulação do poder, que já não se prende mais em moldes, mas os atravessa, em uma modulação constante e interminável. Em outros termos, na sociedade de controle, o poder não age no enclausuramento dos moldes fixados pelos espaços repartidos da sociedade disciplinar, mas encontra-se agora adaptado aos moldes deformáveis da pós-modernidade. Um poder cujos meios confundem discursos e práticas, agindo subrepticiamente na opacidade da suposta transparência que defende.

É precisamente nesse ponto que avaliamos a possibilidade de encontrarmos na materialidade discursiva pontos que remetam a um funcionamento que se possa caracterizar

\footnotetext{
${ }^{187}$ Na introdução do presente trabalho, informamos que DELEUZE, G., ([1990] 2008, p. 219) considera que Michel Foucault situara o período de funcionamento das sociedades disciplinares entre os séculos XVIII e XIX.
} 
como já marcado por traços reconhecíveis como sendo da sociedade de controle e não mais predominantemente da sociedade disciplinar. Para isso, pesquisamos a presença de princípios moduladores na materialidade dos dizeres do corpus. Mais precisamente, buscamos por elementos discursivos que, funcionando como princípios moduladores, contribuem à caracterização do modo de circulação do poder na sociedade de controle. Como introduziremos a seguir, procuramos por enunciados no eixo do interdiscurso e buscamos elementos linguísticos no eixo do intradiscurso que possam se configurar como princípios moduladores.

Tal empreitada nos parece possível uma vez que, por definição, os princípios moduladores são dizeres. Isto é, segundo Deleuze ([1990] 2008), a modulação é o modo de ação da sociedade de controle, que não age por imperativos, como fazia a sociedade disciplinar. Modulações são moldes que se autodeformam, mudam constantemente, garantindo assim que nada chegue ao término. A garantia desse funcionamento interminável é possibilitada pelos princípios moduladores - ou dizeres que funcionam como modulações -, que regem a sociedade de controle, exigindo atualizações contínuas e, portanto, promovendo a motivação e assegurando o controle permanente. Com Deleuze, podemos dizer que um princípio modulador instaura/demanda uma ou mais práticas não discursivas através de uma prática discursiva. Disse Deleuze ([1990] 2008, p. 221):

O princípio modulador do 'salário por mérito' tenta a própria Educação nacional: com efeito, assim como a empresa substitui a fábrica, a formação permanente [outro princípio modulador ${ }^{188}$ ] tende a substituir a escola, e o controle contínuo substitui o exame.

Assim, durante a análise dos dizeres do corpus, essa relação entre discurso e sociedade de controle será observada a partir da incidência dos princípios moduladores em ambos os eixos discursivos.

\section{Considerações sobre o capítulo}

Neste capítulo, buscamos perceber o modo de funcionamento do livro didático na sociedade em que vivemos. Vimos inicialmente que, desde o início de suas atividades, os poderes públicos responsáveis pelo livro didático vêm exercendo o controle sobre ele. Através de procedimentos e instrumentos legais, esse controle garante que o livro escolhido pelo

\footnotetext{
${ }^{188}$ Nossa observação.
} 
professor tenha sido já pré-selecionado e autorizado por esses órgãos públicos. Isto é, a verdade que o livro didático fará circular é já pré-selecionada, pré-aprovada e autorizada pelos órgãos públicos antes mesmo de o professor ter acesso a esse material.

No item 2.2, observamos que a força do mercado editorial sempre esteve presente nos processos de adoção de materiais didáticos, atuando junto aos professores e escolas, com o objetivo de ter o controle sobre a escolha. Essa atuação do mercado editorial tem exigido atualizações e novos direcionamentos dos programas, além da criação de instrumentos legais para contê-la. Ao mesmo tempo em que demanda atualizações, essa força também se atualiza; pois, como vimos, a cada proibição e penalidade impostas pelo Programa às editoras, novas estratégias são mobilizadas para garantir a participação expressiva.

Ao discutirmos o programa de adoção do LDI na escola pública no item 2.3, vimos que muitos dos compromissos estabelecidos pelo PNLD 2011 não foram seguidos. As respostas dos professores ao segundo questionário nos informam que, em algumas escolas, o número de coleções não foi suficiente para a entrega a todos os alunos, em outras, a distribuição das coleções não foi realizada antes do início do ano letivo. Alguns professores informam que, diferentemente do planejado e estabelecido pelo PNLD 2011, ambas as coleções foram adotadas no mesmo ano ou em anos imediatamente consecutivos; outros informam, ainda, que um mesmo volume foi utilizado para dois anos escolares enquanto os outros volumes ficaram abandonados, sem utilização. Em algumas escolas, como vimos, não foi possível utilizar o LDI como um material consumível, nos termos do PNLD 2011, pois muitos alunos tiveram de reutilizá-lo. Mesmo apontando desde a falta de aparelhos de áudio para a utilização do CD que acompanhou obrigatoriamente o LDI do PNLD 2011 até a incompatibilidade entre a realidade dos alunos e os temas abordados, além do nível de exigência de conhecimento de língua, muitos professores consideram positiva a proposta de adoção do LDI na escola pública brasileira. Portanto, será ainda necessário que as novas edições do Programa considerem tanto o aluno quanto o professor, para que as renovações ocorram de modo a contribuírem com a educação brasileira em sua complexidade e heterogeneidade.

A partir da reflexão sobre disciplina e sociedade, vimos que a disciplina é a construção social do "ensinável" e que o livro didático é representado socialmente como aquilo que materializa o "ensinável". Se considerarmos a chegada do LDI na escola pública agora em 2011 como uma medida para legitimar a disciplina de língua inglesa, podemos afirmar que o papel do LDI neste momento é também estabelecer o “ensinável” da língua inglesa, ou aquilo que pode ser ensinado, demarcando, assim, os limites dessa disciplina no âmbito do ensino 
público. Neste momento, em que as novas tecnologias de informatização se aproximam cada vez mais da escola pública ${ }^{189}$ e que mais e mais alunos de todas as classes sociais têm acesso aos saberes e às verdades que circulam globalmente, estabelecer os limites do "ensinável" pode representar tanto um porto seguro contra o desconforto de não se ter o controle daquilo que ocorre em sala de aula como pode, também, significar o adiamento de um enfrentamento inevitável.

Com a discussão sobre o discurso de verdade, chegamos à afirmação de Foucault ([1982, p. 219] 1995, p. 243) que estabelece que o poder só existe quando colocado em ação. A partir dessa afirmação, traçamos a relação entre o discurso sobre o LDI e o discurso do LDI. Isto é, acreditamos que o nosso objeto, o discurso sobre o LDI, coloca em ação o discurso do LDI. Se na concepção foucaultiana o poder é definido como uma ação sobre outra e deve ser posto em ação para existir, considerando-se que o LDI é representado em nossa sociedade como exercendo o poder de discurso de verdade, então, é possível que haja uma ação incidindo sobre as ações que o LDI motiva, para que ele funcione como um discurso de verdade. Esse modo de funcionamento do poder é investigado em relação ao discurso sobre o LDI nos capítulos da segunda parte deste trabalho.

O item 2.6 procurou estabelecer algumas diferenças entre o discurso do LDI e o discurso sobre o LDI. Vimos que o discurso sobre $\mathrm{X}$ tem especificidades que o marcam já como outro discurso. Primeiramente, observamos que tanto o objeto como o sujeito de um e outro discurso (de e sobre) não se igualam. A voz que fala no discurso do livro didático é aquela da função-autor. Isto é, de acordo com Michel Foucault, o domínio da função-autor caracteriza-se pela dispersão das posições ocupadas pelo sujeito: a "pluralidade de "eus"” (FOUCAULT, M., [1969], 2002, p. 55). Portanto, não é possível associar a função-autor a um só indivíduo; sabe-se apenas que há a "pluralidade de 'eus'. Já o sujeito enunciador do discurso sobre $\mathrm{X}$ é aquele chamado a assumir o lugar de autoridade, para discorrer sobre algo que, no momento do discurso, se configurará como a verdade do especialista. Percebemos, também, que o sujeito enunciador do discurso sobre X fala de sua relação com o seu objeto de discurso e que, tratando dele, revitaliza parte da memória sobre seu objeto e apaga outras pelo efeito da linearização e homogeneização da memória, de acordo com o estabelecido por Mariani (1999).

\footnotetext{
189 Já em 10 de junho de 2010, portanto, antes da adoção do LDI na escola pública, pela Resolução n. 17 do Conselho Deliberativo do FNDE, foram estabelecidas as normas e diretrizes para que os Estados da União se habilitem ao programa denominado PROUCA - Programa um computador por aluno. O programa visa à aquisição de computadores portáteis com conteúdos pedagógicos para a escola pública destinados ao nível de educação básica. Disponível em: 〈http://www.uca.gov.br/institucional/noticiasAdesao.jsp〉. Acesso em: 20 mai. 2013.
} 
No último item deste capítulo, Discurso e sociedade de controle, discutimos a relação entre discurso e sociedade, observando especialmente sobre como o discurso carrega as marcas linguísticas, mas também históricas e ideológicas, de cada sociedade. Construímos aí nosso argumento de que, na sociedade de controle, o discurso é marcado por elementos do intradiscurso e por indícios de enunciados no interdiscurso que podem produzir o efeito de princípios moduladores (DELEUZE, G., ([1990] 2008), característicos da sociedade de controle. Com base nos estudos sobre a constituição do sujeito pela ideologia, pela história e pela/na língua, estabelecemos a direção que devemos considerar para a análise dos dizeres do corpus de pesquisa.

Essas relações que traçamos aqui, ainda de modo bem frágil, compõem nossas categorias de análise, que esperamos apresentar mais claramente no próximo capítulo em que são articuladas com a análise dos dizeres do discurso sobre o LDI. 
PARTE 2

ANÁLISE DE DIZERES DO DISCURSO SOBRE O LIVRO DIDÁTICO DE INGLÊS 


\section{CAPÍTULO 3}

\section{AS CATEGORIAS DE ANÁLISE}

Antes de iniciarmos a análise dos dizeres do corpus de pesquisa, apresentaremos as categorias que nos auxiliaram a desenhar os recortes para a análise. As categorias de análise foram estabelecidas a partir dos dizeres de Michel Foucault ${ }^{190}$ sobre as noções de saber e de poder, como argumentamos abaixo.

\subsection{As três categorias de análise do corpus}

Considerando que nossa hipótese de pesquisa defende que o discurso sobre o livro didático de inglês investe poder no livro didático, para que ele funcione como um discurso de verdade, estabelecemos três categorias de análise a partir das noções foucaultianas de poder, saber e da articulação da relação de poder. Em princípio, essas categorias são mobilizadas uma a uma, separadamente, apenas como metodologia de análise. No entanto, as três categorias podem ser observadas em outras interpretações dos excertos, sendo elas partes constituintes do movimento da relação saber-poder. Faremos, por ora, a separação em três itens, para que possamos delineá-las. Respectivamente, temos as categorias:

1. Uma ação sobre outra ou um conjunto de ações sobre outras ações (FOUCAULT, M., 1982, p. 220; nossa tradução), para pesquisarmos se e como o discurso sobre o livro didático de inglês se configura como um modo de ação sobre outras ações.

2. "Um conjunto de procedimentos regulados para a produção, a lei, a repartição, a circulação e o funcionamento dos enunciados” (FOUCAULT, M., [1979] 2004, p. 14), para observarmos se e como o livro didático de inglês é representado como esse conjunto de procedimentos, ou seja, como um saber, pelo discurso sobre o LDI.

3. A articulação da relação de poder, para que, analisando essa articulação, possamos perceber se e como é possível caracterizar o discurso sobre o LDI como um investimento de poder que torna o LDI um discurso de verdade.

${ }^{190}$ Cf. FOUCAUlT, M., [1979] 2004; FOUCAUlT, M., 1982. 
É necessário ainda neste momento discutir o lugar do professor e também do LDI em relação aos conceitos que embasam essas categorias de análise. Isso porque devemos considerar que Michel Foucault estabelece dois elementos indispensáveis para a articulação de uma relação de poder. Disse Foucault ${ }^{191}$ ([1982] 1995, p. 243),

Uma relação de poder, ao contrário, se articula sobre dois elementos que lhe são indispensáveis por ser exatamente uma relação de poder: que "o outro" (aquele sobre o qual ela se exerce) seja inteiramente reconhecido e mantido até o fim como o sujeito de ação; e que se abra, diante da relação de poder, todo um campo de respostas, reações, efeitos, invenções possíveis.

Portanto, nossa terceira categoria deverá ser desmembrada em dois elementos. Discutiremos, em seguida, cada um desses elementos em relação às categorias de análise do corpus desta pesquisa.

\section{$3.2 \mathrm{O}$ professor como uma pessoa que age}

Vemos que o primeiro elemento considera que o poder é exercido sobre "o sujeito de ação", uma pessoa que age $e^{192}$. Essa afirmação poderia pôr em risco nossa hipótese de que o discurso sobre o LDI investe poder no LDI, por ser o livro didático um objeto e não, obviamente, uma pessoa. Porém, em linhas anteriores, à página 243 do mesmo texto, Foucault já estabelecera ${ }^{193}$, como citamos no capítulo anterior em 2.6.2, que a relação de poder é um modo de agir sobre as ações de outros, e não diretamente e imediatamente sobre essas pessoas. Assim, acreditamos ser possível localizar o LDI e o professor nesse funcionamento. Afinal, o LDI comporta as ações que devem ser executadas pelo professor e, também, pelo aluno, segundo as pesquisas que analisaram o discurso de vários materiais didáticos.

Ao analisar os papéis do professor e do aluno no ensino apostilado, Coracini (1999, p. 53) percebe a construção das representações: "o professor é o mediador autorizado das informações contidas no material e o aluno aquele que as acumula". Analisando o livro didático para o ensino de Língua Portuguesa, Grigoletto (1999, p. 75) observa que os efeitos do discurso do LD constroem representações em que "o papel do professor [...] deve ser de

\footnotetext{
${ }^{191}$ No texto original em inglês, FOUCAULT, M., 1982, p. 220 disse: “[...] a power relationship can only be articulated on the basis of two elements which are each indispensable if it is really to be a power relationship: that "the other" (the one over whom power is exercised) be thoroughly recognized and maintained to the very end as a person who acts; and that, faced with a relationship of power, a whole field of responses, reactions, results, and possible inventions may open up".

${ }^{192}$ Como sublinhamos na citação da nota acima.

${ }^{193}$ FOUCAULT, M., 1982, p. 220 disse: "In effect, what defines a relationship of power is that it is a mode of action which does not act directly and immediately on others. Instead it acts upon their actions: an action upon action, on existing actions or on those which may arise in the present or the future".
} 
mediador entre o livro e o aluno, de modo a garantir o cumprimento das propostas do manual”. À página 68, Grigoletto afirma: “O professor recebe um 'pacote' pronto e espera-se dele que o utilize. Ele é visto como usuário, assim como o aluno, e não como analista”. Em outro texto, Grigoletto (1999a, p. 83) analisa livros didáticos de língua inglesa e discute a relação entre as ações que o LDI comporta e a postura do professor, concluindo que a contenção de sentidos é desejada pelo discurso do livro didático: "O que se nega ao aluno, e também ao professor, já que deste se espera que siga fielmente as instruções do LD, é a construção do sentido na sua necessária historicidade”. Também à página 87 desse último texto, Grigoletto argumenta: "Há uma interdição à interpretação também em relação ao professor, uma vez que todas as respostas lhe são fornecidas no livro do professor e que se espera que siga passo a passo as propostas do livro".

Mesmo ao analisarmos o discurso instrucional dirigido ao professor em manuais de livros didáticos de inglês e em palestras aos professores usuários de materiais de cursos apostilados em nossa dissertação de mestrado ${ }^{194}$, observamos a construção da representação de professor como prolongamento do sujeito-autor dos dizeres das instruções sobre a utilização do LDI. Portanto, espera-se que o professor, representado como o prolongamento do sujeito-autor, faça exatamente o que o autor faria em cada situação de aula.

Desse modo, partindo da concepção foucaultiana de que o poder é exercido sobre as ações de um outro que, por sua vez, é reconhecido e mantido como uma pessoa que age ${ }^{195}$, consideramos, pois, o professor como essa pessoa que age.

3.3 A possibilidade de se abrir "todo um campo de respostas, reações, efeitos e invenções"196

O segundo elemento imprescindível para o estudo das relações de poder, de acordo com essa citação de Foucault que destacamos acima no título deste subitem, deve considerar a possibilidade de se abrir "todo um campo de respostas, reações, efeitos e invenções" diante de uma relação de poder. Acreditamos que esse seja realmente um aspecto importantíssimo a ser considerado na análise; pois, ao menos potencialmente, há essa possibilidade de reações que contribuem não para o escape total, ou para a "libertação" do sujeito, situação que o colocaria

\footnotetext{
${ }^{194}$ Cf. BRAGA, M. D. W., 2008, A prevenção de metaforização no discurso pedagógico instrucional para o ensino de língua inglesa. Disponível em: 〈http://dedalus.usp.br>; publicada em inglês sob o título Prevention of Metaphorisation: a discursive analysis on giving instructions. Saarbruecken, Germany: VDM Verlag Dr. Müller Aktiengesellschaft \& Co, 2010.

${ }^{195}$ Como informamos em nota anterior, na publicação em português, a "person who acts" do original (FOUCAULT, M., 1982, p. 220) foi traduzida como "o sujeito de ação" (FOUCAULT, M., [1982] 1995, p. 243). ${ }^{196}$ FOUCAULT, M. ([1982, p. 220] 1995, p. 243).
} 
fora das relações de poder, visto que é impossível, mas para aquilo que Foucault chamou de "novas formas de subjetivação".

Mais especificamente, podemos dizer que Foucault, ainda nesse mesmo texto, define liberdade ao contrastá-la à escravidão; ou seja, situações diversas em que há, para aquele que é livre, possibilidades de reações e comportamentos. Disse Foucault ${ }^{197}$ ([1982] 1995, p. 244):

Quando definimos o exercício do poder como um modo de ação sobre as ações dos outros, quando as caracterizamos pelo "governo" dos homens, uns pelos outros - no sentido mais extenso da palavra, incluímos um elemento importante: a liberdade. O poder só se exerce sobre "sujeitos livres", enquanto "livres" - entendendo-se por isso sujeitos individuais ou coletivos que têm diante de si um campo de possibilidade onde diversas condutas, diversas reações e diversos modos de comportamento podem acontecer. Não há relação de poder onde as determinações estão saturadas - a escravidão não é uma relação de poder, pois o homem está acorrentado (trata-se então de uma relação física de coação) - mas apenas quando ele pode se deslocar e, no limite, escapar.

Esse "campo de respostas, reações, efeitos e invenções" pode ser tanto o espaço para o surgimento de novas formas de subjetivação como o lugar de reafirmação do mesmo, isto é, um lugar em que o novo é a aparente renovação de algo que não muda. Um espaço que o trabalho do professor, como uma pessoa que age no processo de ensino, deve insistir em ocupar, mesmo atuando inevitavelmente em meio às relações de poder que procuram cegá-lo à existência de tal espaço. Em outros termos, de acordo com o pensamento de Foucault, esse espaço é uma das condições necessárias para a articulação de uma relação de poder e, portanto, deverá ser percebido em todas as relações de poder. Contudo, é possível haver discursos e práticas que trabalham no sentido de controlar as ações que possam vir a ser exercidas nesse espaço, garantindo tanto a ilusão de mudança quanto a permanência daquilo que já se encontra estabelecido.

\subsection{As categorias de análise e os dizeres do corpus}

Em relação à dificuldade já mencionada de se separar os dizeres, como se os efeitos de sentido pudessem ser isolados, sem se mesclarem, confundirem, convergindo e divergindo o

\footnotetext{
${ }^{197}$ O texto original, FOUCAULT, M. (1982, p. 221), diz: "When one defines the exercise of power as a mode of action upon the actions of others, when one characterizes these actions by the government of men by other men in the broadest sense of the term - one includes an important element: freedom. Power is exercised only over free subjects, and only insofar as they are free. By this we mean individual or collective subjects who are faced with a field of possibilities in which several ways of behaving, several reactions and diverse comportments may be realized. Where the determining factors saturate the whole there is no relationship of power; slavery is not a power relationship when man is in chains. (In this case it is a question of a physical relationship of constraint.)"
} 
tempo todo, procuramos corresponder as sequências discursivas às categorias de análise, nossa construção, que mais se nos apresentam como relacionáveis. No caso do discurso profissional, propomos a seguinte correspondência entre as respostas dos professores de inglês da rede pública de ensino às perguntas dos questionários ${ }^{198} \mathrm{e}$ às categorias conforme o quadro abaixo.

\begin{tabular}{|c|c|c|c|}
\hline & Categoria 1: PODER & Categoria 2: SABER & $\begin{array}{c}\text { Categoria 3: } \\
\text { ARTICULAÇÃO }\end{array}$ \\
\hline & $\begin{array}{l}\text { uma ação sobre outra ou } \\
\text { um conjunto de ações } \\
\text { sobre outras ações }\end{array}$ & $\begin{array}{l}\text { um conjunto de procedi- } \\
\text { mentos regulados para a } \\
\text { produção, a lei, a repar- } \\
\text { tição, a circulação e o } \\
\text { funcionamento dos } \\
\text { enunciados }\end{array}$ & $\begin{array}{l}\text { articulação saber-poder: } \\
\text { a) o poder é exercido sobre } \\
\text { uma pessoa que age; } \\
\text { b) diante de uma relação de } \\
\text { poder, há a possibilidade } \\
\text { de se abrir "todo um } \\
\text { campo de respostas, } \\
\text { reações, efeitos e } \\
\text { invenções". }\end{array}$ \\
\hline $\begin{array}{l}\text { Primeiro } \\
\text { questionário }\end{array}$ & $\begin{array}{l}\text { 1 a pergunta: } \\
\text { A partir de 2011, as } \\
\text { escolas públicas ado- } \\
\text { tarão livros didáticos } \\
\text { para o ensino de inglês } \\
\text { para o Fundamental II, } \\
\text { do } 6^{\circ} \text { ao } 9^{\circ} \text { ano. Qual é } \\
\text { sua opinião sobre essa } \\
\text { medida? }\end{array}$ & $\begin{array}{l}2^{\text {a }} \text { e } 3^{\text {a }} \text { perguntas: } \\
\text { 2. Que tipo de material } \\
\text { você utiliza atualmente? } \\
\text { Há quanto tempo você } \\
\text { utiliza esse material? } \\
\text { 3. Como a utilização do } \\
\text { livro didático afetaria } \\
\text { seu dia a dia? }\end{array}$ & $\begin{array}{l}4^{\text {a }} \text { pergunta: } \\
\text { Em sua opinião, de que } \\
\text { modo o livro didático } \\
\text { poderá (ou não) contribuir } \\
\text { para o ensino de inglês } \\
\text { como língua estrangeira na } \\
\text { escola pública? Quais são as } \\
\text { vantagens e/ou desvanta- } \\
\text { gens? }\end{array}$ \\
\hline $\begin{array}{l}\text { Segundo } \\
\text { questionário }\end{array}$ & $\begin{array}{l}5^{\text {a }} \text { pergunta: } \\
\text { Na sua opinião, quais os } \\
\text { pontos que melhoraram } \\
\text { e quais precisam ainda } \\
\text { ser melhorados nesse } \\
\text { processo de adoção? }\end{array}$ & $\begin{array}{l}3^{\text {a }} \text { pergunta: } \\
\text { Caso você utilize algu- } \\
\text { ma das coleções ado- } \\
\text { tadas, você está satis- } \\
\text { feito(a)? Explique os } \\
\text { motivos. }\end{array}$ & $\begin{array}{l}4^{\text {a }} \text { pergunta: } \\
\text { Em sua opinião, de que } \\
\text { modo o livro didático está } \\
\text { (ou não) contribuindo para } \\
\text { o ensino de inglês como } \\
\text { língua estrangeira na escola } \\
\text { pública? Quais são as } \\
\text { vantagens e/ou desvanta- } \\
\text { gens dessa adoção? }\end{array}$ \\
\hline
\end{tabular}

Fig. 4: As categorias de análise e as perguntas dos questionários 
Considerando-se os dois elementos indispensáveis para o estudo das relações de poder, a terceira categoria, articulação saber-poder, como incluímos no quadro acima, divide-se em: a) o poder é exercido sobre uma pessoa que age;

b) diante de uma relação de poder, há a possibilidade de se abrir "todo um campo de respostas, reações, efeitos e invenções".

A quinta e última pergunta do primeiro questionário, sobre os comentários do professor respondente em relação à adoção e/ou utilização do livro didático de inglês na escola pública, não foi respondida por todos os participantes. Desse modo, não a relacionamos às categorias de análise. As duas primeiras perguntas do segundo questionário são perguntas objetivas e informativas de múltipla escolha sobre qual coleção foi escolhida e se o professor respondente participou dessa escolha. Portanto, também essas não foram relacionadas às categorias de pesquisa.

\subsection{Os princípios moduladores}

Um último aspecto que observamos nos dizeres do corpus de pesquisa diz respeito ao modo como os princípios moduladores ${ }^{199}$, que caracterizam o funcionamento das sociedades de controle, incidem nos eixos do intradiscurso e do interdiscurso. No eixo do interdiscurso, procuramos por enunciados que remetam às moldagens autodeformantes, exigindo mudanças contínuas. No intradiscurso, observamos como os elementos linguísticos contribuem à formação dos princípios moduladores, isto é, dizeres que funcionam como modulações. Nas palavras de Deleuze ([1990] 2008, p. 221), uma modulação é "uma moldagem autodeformante que mudasse continuamente, a cada instante, ou como uma peneira cujas malhas mudassem de um ponto a outro".

Essa busca por princípios moduladores não se constitui como uma categoria de análise, mas estabelece um posto de observação para a análise. Isto é, através dos efeitos percebidos pela análise, poderemos relacionar o funcionamento discursivo dos dizeres do corpus ao funcionamento característico da sociedade de controle.

O próximo capítulo trata da primeira categoria de análise. Analisamos os dizeres dos discursos oficial, profissional e midiático consecutivamente.

${ }^{199}$ Como argumentamos em 2.7. 


\section{CAPÍTULO 4}

\section{PODER: O INVESTIMENTO DO DISCURSO SOBRE O LDI}

A definição de poder concebida por Michel Foucault, publicada em inglês como " $a$ set of actions upon other actions" (FOUCAULT, M., 1982, p. 220) e traduzida por Carrero (FOUCAULT, M., [1982] 1995, p. 243) como "uma ação sobre a ação", sustentará nossa análise durante este capítulo, compondo nossa primeira categoria de análise. Neste capítulo, a análise se concentrará em perceber se e, se afirmativo, como o discurso sobre o LDI produz o efeito de funcionar como um modo de ação sobre outras ações, como um poder, para que possa também investir poder no LDI, representando-o como verdade.

Predominantemente, o segmento do discurso oficial do nosso corpus de pesquisa é aquele que mais concentra dizeres em que percebemos o efeito discursivo considerado em nossa primeira categoria: um conjunto de ações sobre outras ações. Tal predominância pode ser compreendida se entendermos o discurso oficial como a voz dos encarregados de julgarem o que deve funcionar como verdade ou, nas palavras de Foucault ([1979] 2004, p. 12),

Cada sociedade tem seu regime de verdade, sua "política geral" de verdade: isto é, os tipos de discurso que ela acolhe e faz funcionar como verdadeiros; os mecanismos e as instâncias que permitem distinguir os enunciados verdadeiros dos falsos, a maneira como se sanciona uns e outros; as técnicas e os procedimentos que são valorizados para a obtenção da verdade; $\underline{0}$ estatuto daqueles que têm o encargo de dizer o que funciona como verdadeiro.

Em outros termos, o sujeito enunciador do discurso oficial ocupa um lugar legitimado socialmente para exercer o controle sobre práticas discursivas e não discursivas que, naquela sociedade, funcionam como saberes, como verdades. Vejamos, então, alguns desses dizeres.

\subsection{Dizeres do discurso oficial}

O primeiro documento emitido pelo MEC e assinado pelo Presidente do FNDE, Daniel Silva Balaban, e pela Secretária de Educação Básica, Maria do Pilar Lacerda Almeida e Silva, contendo informações específicas sobre o PNLD 2011, foi aguardado ansiosamente pelas editoras durante o ano de 2008. Com algum atraso, o documento chegou às editoras em meados de novembro daquele ano. Intitulado Edital de Convocação para Inscrição no 
Livro Didático - PNLD 2011, o documento informou as editoras (denominadas "titulares de direito autoral") sobre datas, prazos limites, especificações sobre as coleções a serem inscritas, condições de participação, procedimentos para a inscrição das coleções e entrega da documentação. Além disso, o Edital contém dez anexos com informações sobre a estrutura editorial, as especificações técnicas para a produção das coleções, os critérios observados para a avaliação das coleções inscritas, modelos de declarações e fichas cadastrais. A partir dessas informações, os titulares de direito autoral deram início à produção ou à adaptação das coleções de livros didáticos, com prazo de entrega entre 13 e 17 de abril de 2009.

Analisamos, a seguir, a primeira sequência discursiva. Ela pertence ao Edital e referese ao Guia de Livros Didáticos, um documento que foi posteriormente disponibilizado às escolas para a escolha das coleções didáticas. O item 6 do Edital de Convocação tem o título Do Processo de Avaliação e Seleção das Obras; analisamos os dizeres do item 6.3.

$\mathrm{S} 1^{200}$

\subsection{Do Guia de Livros Didáticos}

Constarão no Guia de Livros Didáticos as resenhas das coleções selecionadas, os princípios e critérios que nortearam a avaliação pedagógica e os modelos das fichas de análise. O Guia de Livros Didáticos será encaminhado às escolas públicas de ensino fundamental e disponibilizado na Internet com o objetivo de auxiliar os professores na escolha das coleções didáticas, que serão utilizadas no período a ser estabelecido por resolução do Conselho Deliberativo do FNDE.

Com cinquenta e duas páginas dedicadas ao componente Língua Estrangeira Moderna, o Guia de Livros Didáticos objetivou, como informado no item 6.3 do Edital de Convocação, a "auxiliar os professores na escolha" do livro didático que seria utilizado em suas aulas. Notamos a pertinência dessa sequência para nossa primeira categoria de análise (uma ação sobre outra ou um conjunto de ações sobre outras ações) não apenas pelo efeito discursivo desses dizeres, mas também pela prática não discursiva que se deseja estabelecer a partir desse discurso.

Em relação ao efeito discursivo, vemos que "auxiliar os professores na escolha" se caracteriza como a ação (“auxiliar”) de um (os órgãos públicos responsáveis pelo Guia) sobre a ação (escolher) de outro (o professor). Lembramos que, para Foucault, essa é a definição de

\footnotetext{
${ }^{200} \mathrm{~S}$ se refere à sequência discursiva, ou dizeres do discurso que analisamos; S1 é a primeira sequência discursiva e assim sucessivamente. Como informamos anteriormente, as sequências discursivas foram reproduzidas exatamente como as obtivemos nos textos originais.
} 
poder. Nossas indagações, aqui, se dão em várias instâncias. De início, podemos pensar no modo como o professor e o livro didático são representados nesses dizeres. O professor parece ser representado como um profissional que não consegue optar sozinho e que precisa de ajuda para escolher o material com o qual trabalhará. Questionamos, ainda, o tipo de escolha que poderia se configurar, tendo sido ela auxiliada por outro. Isto é, uma escolha resultante da ação auxiliadora de outro está, certamente, suscetível a ser influenciada por esse outro. A escolha do professor será, então, influenciada, guiada pelas informações desse documento, sugestivamente denominado Guia de Livros Didáticos. Trataremos das informações desse documento de modo mais detalhado ao analisarmos os dizeres sob a nossa segunda categoria.

Observamos, também, que o dizer "auxiliar os professores na escolha das coleções didáticas" suscita práticas não discursivas que corroboram a noção de poder como uma ação sobre outra ou um conjunto de ações sobre outras ações. Afinal, há um trabalho intenso de profissionais, especialistas ${ }^{201}$ nas áreas contempladas em cada PNLD, durante o período de pré-avaliação das coleções inscritas, culminando na elaboração do Guia. O documento, por sua vez, contém informações que certamente resultam das ações desses profissionais, desse trabalho intenso; porém, primordialmente, trazem como verdades aquilo que os órgãos públicos envolvidos nesse processo assim consideram ${ }^{202}$. Assim compostas, essas informações servirão de guia para que os professores façam suas ações, nesse caso, suas escolhas. Contudo, essas ações sobre outras ações, como práticas não discursivas neste caso, são ladeadas de discurso, ou seja, são guiadas por discurso. Assim, os dizeres do discurso oficial vão moldando as ações almejadas, passo a passo, movidos pelo desejo de controle dessas ações.

A cada passo, também, a ação do professor (a escolha) vai sendo adiada. Vemos aí, como um efeito discursivo, o modo de funcionamento característico da sociedade de controle: o adiamento do término. Ou seja, o dizer do Edital não informa que o professor simplesmente fará a escolha da coleção com a qual trabalhará; mas, antes disso, informa que um documento (o Guia) será cuidadosamente elaborado para auxiliar o professor a fazer sua escolha, a

\footnotetext{
201 Apesar de haver muita crítica a respeito da falta de transparência nessa fase de pré-avaliação, os nomes dos avaliadores e seus respectivos vínculos institucionais são disponibilizados nas páginas introdutórias do Guia; porém, antes da publicação desse documento, as identidades dos avaliadores são protegidas, para não ficarem expostos a pressões.

${ }^{202}$ Os especialistas avaliam as coleções de acordo com os critérios estabelecidos pelos órgãos responsáveis pelo Programa (Ministério da Educação, Secretaria de Educação Básica e Fundo Nacional de Desenvolvimento de Educação). Tais critérios são organizados em noventa e duas perguntas (PNLD 2011) que compõem a ficha de avaliação utilizada pelos especialistas. Durante esse processo, os especialistas trabalham com as coleções descaracterizadas e não conhecem os títulos que aprovam ou reprovam. Os resultados são informados à coordenação do programa que, por sua vez, identifica os títulos e os repassa ao MEC.
} 
exercer sua ação. Isto é, antes de realizar sua ação (a escolha), o professor deverá ler as resenhas, os princípios e critérios observados na avaliação, os modelos de fichas etc,; pois, fazendo isso, o professor estará sendo preparado, auxiliado, a fazer a escolha.

\subsection{Dizeres do discurso profissional}

Analisaremos, a seguir, algumas respostas dos professores à primeira pergunta do primeiro questionário, considerando essa mesma categoria de análise: uma ação sobre outra ou um conjunto de ações sobre outras ações. Relembrando, a primeira pergunta desse questionário é:

1) A partir de 2011, as escolas públicas adotarão livros didáticos para o ensino de inglês para o Fundamental II, do $6^{\circ}$ ao $9^{\circ}$ ano. Qual é sua opinião sobre essa medida?

S2 - P1Q1:

Acho ótima, pois nunca se deu muita importância para o ensino do inglês e a falta de recursos é realmente um problema para o professor que necessita, constantemente, procurar material para suas aulas. O caderno do aluno que usamos tem facilitado muito nossa vida. (É recente a distribuição). O inglês ficou esquecido por muito tempo.

Vemos que P1Q1, um sujeito que fala do lugar de professor de inglês como língua estrangeira para o $6^{\circ}$ ano da rede pública de ensino, associa a adoção de livros didáticos à importância atribuída à disciplina de língua inglesa. Isto é, P1Q1 estabelece uma relação direta entre o pouco reconhecimento atribuído à disciplina e a falta de materiais. Nos dizeres de P1Q1, percebemos que a recente distribuição do Caderno do Aluno ${ }^{203}$ e o programa de adoção do livro didático em 2011 são responsáveis por mudar o quadro sobre o esquecimento do ensino de inglês, que agora pertence ao passado: "o inglês ficou esquecido por muito tempo".

Podemos, então, delinear alguns traços da representação de professor de inglês da escola pública nos dizeres desse sujeito. Isto é, o professor de inglês é aquele que admite lecionar uma disciplina pouco reconhecida, considerada sem "muita importância" e, por isso, convive "constantemente" com o "problema" de encontrar materiais para trabalhar. É ainda aquele que, diante da "falta de recursos" e do esquecimento do inglês "por muito tempo", se vê na necessidade de buscar em algum lugar materiais para suas aulas. A busca é percebida

\footnotetext{
${ }^{203}$ Em referência ao material didático para o ensino de inglês distribuído pelo Governo do Estado de São Paulo, através do Programa São Paulo Faz Escola.
} 
por P1Q1 como "um problema" e não como um desafio que poderia contribuir a um ensino que valorizasse o contexto em que esse mesmo professor se insere. Isto é, ao considerar a "falta de recursos" como um problema, P1Q1 parece atribuir ao LDI a função de solucionar esse "problema", sanando a falta e promovendo a completude das aulas. Por outro lado, se fosse tomada como um desafio, essa falta poderia mobilizar tanto o professor quanto seus alunos a buscarem materiais mais afinados ao seu contexto, às suas necessidades, envolvendoos e implicando-os em processos de ensino e de aprendizagem mais significativos e relevantes para eles.

Assim, o LDI é considerado por P1Q1 como aquilo que coroa o ensino de inglês, reconhecendo-o e dando-lhe a importância necessária. Em outros termos, nos dizeres de P1Q1, a medida governamental de adoção do LDI eleva o ensino de inglês à condição já experimentada por outras disciplinas que não ficaram esquecidas por muito tempo.

A partir dos dizeres de P1Q1, percebemos que a ação governamental de adotar o LDI tem impacto direto sobre a ação do professor em aula; pois, se sem os "recursos" didáticos, ele necessita buscar materiais para suas aulas, com o LDI, ele não mais precisará fazê-lo. A adoção do LDI, então, age diretamente na ação do professor, facilitando sua vida. Portanto, podemos dizer que percebemos, nesses dizeres de P1Q1, o movimento de uma ação (a ação governamental para a adoção do LDI) sobre outra ação (a ação de facilitar a vida do professor) que, segundo Foucault ${ }^{204}$, é a própria definição de poder.

Com os seguintes dizeres ${ }^{205}$, $\mathrm{P} 2 \mathrm{Q} 1$ responde à primeira pergunta do questionário:

S3 - P2Q1

Muito Bom. O livro para e o dicionário são materiais de apoio e consulta que pode ajudar bastante.

É preciso lembrar que, apesar de P2Q1 incluir o dicionário em sua resposta à pergunta sobre a adoção de livros didáticos, esse material não faz parte das coleções distribuídas pelo PNLD 2011. Por outro lado, embora não haja quaisquer especificações nem detalhes sobre esses materiais nos documentos do PNLD 2011 em relação à língua estrangeira, a distribuição de obras complementares e dicionários é prevista pelo programa de modo geral.

\footnotetext{
${ }^{204}$ FOUCAULT, M., 1982, p. 220.

205 As amostras dos questionários respondidos encontram-se no ANEXO D.
} 
Mesmo nessa resposta concisa, é possível perceber que P2Q1 aprova com entusiasmo a medida governamental. Porém, devido à sua brevidade, essa resposta exige do olhar analítico uma observação para além das indagações que suscita.

Inicialmente, o termo riscado de seu dizer (para) não nos permite estabilizar algum efeito de sentido, ao menos momentaneamente, para a análise. Mesmo riscado, o termo não foi apagado do dizer e continua, portanto, a produzir efeitos discursivos. Há aí um jogo de possibilidades. Seria o termo recusado por $\mathrm{P} 2 \mathrm{Q} 1$ a preposição para, retomando, assim, parte do texto da pergunta "livros didáticos para o ensino de inglês para o Fundamental II"? Se assim for, talvez, ao livro didático estaria sendo atribuída a função de material de apoio, e, respectivamente, ao dicionário (que não compõe os materiais do PNLD 2011) a função de material de consulta. Apesar de não ser possível precisar exatamente qual seria o material de consulta e o de apoio nesse dizer, os materiais são representados como importantes para as aulas de P2Q1, talvez, contribuindo pontualmente ao plano de aula por ele elaborado. Mas, com o termo riscado, o dizer de P2Q1 não permite a validação dessa análise.

O termo recusado por $\mathrm{P} 2 \mathrm{Q} 1$ poderia ainda remeter ao prefixo da palavra paradidático que teria sido abandonada. Apesar de esse tipo de material também não compor o pacote do PNLD 2011 para língua estrangeira, o paradidático é constantemente referido no questionário por alguns professores participantes da pesquisa e, até, confundido com o livro de sala (textbook). Nesse caso, a relação entre o livro (paradidático) e sua função (apoio) produziria um efeito de correspondência, entre material e função, mais direta no dizer e mais facilmente reconhecível. Isto é, o livro paradidático é mais comumente usado como material de apoio do que o livro de sala. Apesar de o paradidático não ser o foco da pergunta, é aquele que, na resposta, mais se enquadra como material de apoio. Porém, ao recusar o termo, P2Q1 nos impede de prosseguir nessa linha de análise. Portanto, assim como o termo riscado, nossas duas tentativas de análise devem também ser recusadas.

No entanto, podemos perceber o efeito de uma ação sobre outra no momento em que P2Q1 faz a associação imediata entre a ação governamental de adoção dos materiais (livro e dicionário) cujas funções ("apoio e consulta”) atuarão (“ajudar bastante”) sobre a ação do professor (lecionar). Em outros termos, a ação governamental irá ajudar o professor a agir, fornecendo materiais que ele consultará para executar suas ações (lecionar) e nos quais ele se apoiará. Sem essa ajuda, o professor não terá apoio, nem o que consultar.

Apesar de a resposta inicial ("Muito Bom") produzir um efeito de otimismo e entusiasmo de P2Q1 em relação à adoção dos materiais, o uso de "pode", em "pode ajudar bastante", modaliza o dizer, amenizando a expectativa de $\mathrm{P} 2 \mathrm{Q} 1$ em relação ao que pode o 
LDI. Mesmo que não haja alteração no efeito de uma ação sobre outra ação percebido nesse dizer, temos novamente, nos dizeres de P2Q1, o mesmo efeito produzido pelo termo riscado. Isto é, o entusiasmo inicial do dizer "Muito bom" sofre enfraquecimento, como se fosse também riscado, pelo dizer modalizado "pode ajudar". P2Q1 não afirma com convicção que o livro ajudará muito; simplesmente, diz que o livro pode ajudar. Ou seja, quando algo é considerado muito bom, esperamos que ele ajude muito e não simplesmente que possa ajudar.

Além disso, não sabemos exatamente quem será ajudado. Aqui, aquele que poderá ser ajudado pelos materiais (o professor, o aluno, a aula em si, todos ou outros?) marca ainda sua presença no dizer como um não dito ${ }^{206}$, deixando em aberto o objeto que complementaria o verbo transitivo, ajudar. Esse complemento não é algo que simplesmente não existe, mas que existe em sua falta, marcando seu lugar no discurso como aquilo que, ali, falta. Desta vez, P2Q1 não risca aquilo que complementaria o verbo ajudar, nem tampouco se utiliza de um termo que enfraqueceria ou anularia o efeito do dizer; porém, do mesmo modo, o sentido de ajudar sem saber a quem permanece tão incompleto quanto o termo riscado e o "Muito bom" amenizado.

Observamos nesse dizer riscado e incompleto, mas que permanece produzindo efeitos, o mesmo adiamento da finalização característico do funcionamento da sociedade de controle, em que há sempre o adiamento do término. A modalização dos dizeres ("Muito Bom"/"pode") e a falta de complemento de "ajudar" parecem também corroborar o funcionamento dos princípios moduladores na materialidade linguística do discurso. Isso porque, não sendo assertivas, nem conclusivas, produzem o efeito de adiamento do término ao mesmo tempo em que apontam a várias alternativas, possibilitando o escape ou a abertura de linhas de fuga.

A relevância dessa observação encontra apoio na relação que Deleuze ([1990] 2008, p. 212) faz entre cada sociedade e o modo como ela constrói suas linhas de fuga e também na afirmação de Foucault ([1982] 1995, p. 248): “não há relação de poder sem resistência, sem escapatória ou fuga" ${ }^{207}$. Isto é, para Foucault, a possibilidade de resistência e de escape garante o funcionamento de uma relação de poder na sua microfísica. Ou seja, a resistência ao poder é já pressuposta nas relações de poder e, mais especificamente, atua na capilaridade da microfísica que caracteriza o movimento circular da relação saber-poder. Em Deleuze, vemos que a multiplicidade de opções gerada pelas linhas de fuga assegura o controle, pois as linhas

${ }^{206}$ Cf. PÊCHEUX, M., [1975] 2009, p. 160.

${ }^{207}$ Cf. FOUCAULT, M., (1982, p. 225), "For, if it is true that at the heart of power relations and as a permanent condition of their existence there is an insubordination and a certain essential obstinacy on the part of the principles of freedom, then there is no relationship of power without the means of escape or possible flight". 
de fuga voltam a se interconectar e se misturar às linhas de segmentaridade (e também entre si) no movimento incessante da trama do rizoma. Ao nosso ver, o conceito foucaultiano de resistência e o conceito deleuziano de linhas de fuga apresentam diferentes modos de atuação, respectivamente microfísico e rizomático, por terem sido concebidos a partir da observação de funcionamentos distintos de dois tipos também distintos de sociedade: disciplinar e de controle. Assim, enquanto na sociedade disciplinar a resistência pode ser pensada como uma estratégia do poder e, ao mesmo tempo, como uma possibilidade de "promover novas formas de subjetividade" (FOUCAULT, M, [1982] 1995, p. 239), na sociedade de controle as linhas de fuga podem ser pensadas como estratégias do controle, apresentando possibilidades de fuga, contingentes e pontuais, mas que voltam sempre a se misturar no fluxo interminável da trama.

Retomando os dizeres de P2Q1, podemos perceber que os traços identitários de professor parecem subjazer apagados num pano de fundo, sob a opacidade discursiva, como se também o professor fosse riscado, incompleto e enfraquecido; pois, o professor é um possível objeto gramatical do verbo ajudar. Se assim considerarmos, podemos dizer que o professor fica representado nesse dizer como aquele que necessita da ajuda, do apoio e da consulta propiciada pelo LDI do PNLD. O professor é representado também como alguém que se entusiasma com o novo (a oferta de materiais), mas que, ao mesmo tempo, não sente a segurança desse novo garantida e não tem, ao menos, a certeza a quem o novo irá realmente ajudar. Essas incertezas, percebidas como efeitos nos dizeres de P2Q1, podem ser talvez compreendidas como traços identitários do sujeito fragmentado pelas diferentes filiações ideológicas em que ele se constitui.

Vejamos agora a resposta de mais um professor à primeira pergunta do questionário.

S4 - P3Q1

A algum tempo atrás, trabalhei com livros didáticos, e percebi um interesse muito maior por parte dos alunos. Aprender outra língua, é dificil para eles, eles são muito visuais, e o livro propiciava esse tipo de linguagem à eles, o entendimento se torna mais fácil.

Ao contrário de P1Q1 (“Acho ótima") e P2Q1 ("Muito Bom”), que responderam à pergunta, opinando diretamente sobre a adoção do LDI, P3Q1 narra brevemente sua experiência com livros didáticos. A resposta de P3Q1 coloca o foco no aluno em relação ao aprendizado de inglês. De acordo com P3Q1, o livro didático facilita o aprendizado ("o 
entendimento") por oferecer (“propiciava”) uma linguagem visualmente interessante aos alunos.

Percebemos no dizer de P3Q1 que o professor sai de cena quando entra o LDI. Isto é, ao narrar sua experiência, P3Q1 fala da relação entre aluno, livro didático e aprendizagem de língua estrangeira, mas não se inclui nesses dizeres. Os únicos momentos em que o professor participa dessa narrativa são percebidos nas terminações de primeira pessoa do singular dos verbos trabalhei e percebi. Mesmo assim, há o distanciamento crescente do professor nessa narrativa. $\mathrm{Ou}$ seja, o professor agiu, trabalhando com os livros didáticos, colocando-os em funcionamento, poderíamos dizer. Em seguida, o professor se afasta da narrativa, assumindo a postura de observação, percebendo o interesse dos alunos. Depois desse momento, o professor é elidido; a narrativa prossegue apenas com o LDI e os alunos. Notamos, também, que P3Q1 não apenas percebe o interesse dos alunos, mas nota que esse interesse é "muito maior" e o "entendimento se torna mais fácil" do que quando não havia LDI; ou seja, quando o professor protagonizava a cena. Esses dizeres constroem a representação de professor como aquele que, sem o LDI, não consegue instigar o interesse dos alunos, não consegue propiciar uma linguagem que apele às habilidades visuais dos alunos e não consegue facilitar a compreensão. Percebemos que, aqui, o LDI parece ser fortemente investido de poder pelo discurso que fala sobre ele. Ou seja, o dizer sobre a compreensão facilitada através da linguagem visual propiciada pelo LDI o coloca no lugar central nos processos de aprendizagem e de ensino, reduzindo a importância dos elementos envolvidos nesses processos, como sujeitos que garantem a não estabilização do sentido, a incompletude e a heterogeneidade.

Observamos, portanto, o efeito de movimento de uma ação sobre outra ação nos dizeres de P3Q1; pois, a ação governamental de adotar o LDI levará ao aumento "muito maior" do interesse dos alunos e, por fim, o aprendizado será facilitado. Além dessa sequência de ação sobre ação, notamos nos dizeres de P3Q1 que a presença do LDI atrai o aluno para a aprendizagem fácil e visualmente interessante, atribuindo poder de verdade ao LDI. É preciso dizer que a contribuição do LDI não pode diminuir a necessária implicação de ambos, professor e aluno, no processo de aprendizagem.

Em resposta à mesma pergunta, $\mathrm{P} 4 \mathrm{Q} 1$ escreve: 
S5 - P4Q1

A adoção de livros didáticos para o ensino de Inglês está sendo uma conquista bastante significativa para os professores da área, pois estará previsto o desuso do velho discurso de que não se dá uma boa aula por falta de um suporte teórico.

Nesses dizeres de P4Q1, percebemos, inicialmente, como o sujeito se ilude sobre a unicidade de sentido que produz o efeito de homogeneidade discursiva. Ou seja, apesar da aparente unicidade de sentido, vemos que há aqui, como em qualquer discurso, diferentes possibilidades de interpretação. Uma possível interpretação é que o sujeito acredita no "velho discurso de que não se dá uma boa aula por falta de um suporte teórico" e, por isso, a adoção do LDI será uma "conquista bastante significativa", pois o LDI irá prover o saber teórico que legitimará a aula. Nesse caso, sem o LDI, a aula não é boa porque não tem embasamento teórico. Esse é um "velho discurso", como a velha conversa ou a velha história, que circula há tempos, que todos conhecem, mas nada é feito. Com a adoção do LDI, que trará o "suporte teórico", a aula passará a ser boa e acabará com o "velho discurso", trazendo a vitória, a "conquista". Há, portanto, o movimento de uma ação (a adoção do LDI) sobre outra (dar "uma boa aula"). O LDI, nesse movimento, é justamente o fator transformador do processo que fará com que a aula seja boa.

Em outra interpretação, o sujeito apenas reconhece que o "velho discurso" circula socialmente já há algum tempo ("velho"). Assim, a aula é boa, mas sem o "suporte teórico", sem o LDI, não é considerada boa pela comunidade, pela sociedade. A "conquista" será, então, a legitimação da aula, que já é boa, pelo LDI.

Ainda outra interpretação, porém agora um tanto cruel, é que P4Q1 pode estar sendo irônico e denunciando uma atitude omissa e confortável de alguns professores frente à falta de materiais. Ou seja, a aula não é boa e não pode ser melhorada porque não há "suporte teórico", não há LDI, e não há nada que se possa fazer. Nesse caso, a "conquista" seria ainda para todos os "professores da área", uma vez que a falta de material didático não será mais uma desculpa para a aula não ser boa. Aqui, o "velho discurso" remete ao enunciado a velha desculpa ou a velha ladainha. Assim, o poder do LDI se configura não apenas como o saber, o "suporte teórico" que transformará a aula ruim em boa, mas também como aquilo que colocará em "desuso o velho discurso", não aceitando mais o uso da velha desculpa e tirando alguns professores da posição cômoda do conformismo.

Além dessas interpretações, certamente haverá outras, mas não desejamos, nem seria possível, esgotá-las. Interessa-nos, contudo, perceber que, no movimento de uma ação sobre outra, os dizeres de P4Q1 investem poder de verdade no LDI, representando-o como sendo 
aquilo que garante a qualidade e legitima a aula de língua inglesa. Assim, os dizeres apontam à forte representação de LDI como um lugar de verdade. O LDI é o "suporte teórico", o saber, a verdade.

Vimos, ao final do item 1.3, que historicamente, desde seu surgimento, os livros didáticos nacionais têm o encargo de suprir a ausência da formação dos docentes (BITTENCOURT, C., 2004, p. 489). Também o PNLD atribui ao LDI o papel de levar a "teoria" ao professor, como uma medida para lidar com a deficiência da formação profissional, sendo referido como "fonte de insumo" à página 56 do Edital de Convocação. Segundo Circe Bittencourt ${ }^{208}$, os primeiros livros didáticos eram trabalhados por profissionais que eram, em grande maioria, leigos e autodidatas. Hoje, há a exigência de os professores terem formação no ensino superior para exercerem sua profissão na escola pública. Porém, o livro didático continua com a mesma função dupla de ensinar tanto ao aluno quanto ao professor. Entendemos que, se a formação profissional exigida para o professor não altera o modo como o LD é representado, isto é, não altera essa função atribuída ao LD, as contribuições da formação profissional podem ser questionadas.

A "teoria" que o LDI encerra equivale ao resumo da linha teórica no manual do professor e, quase exclusivamente, às regras formais da língua em relação à prática, ou seja, regras de pronúncia, de uso e gramaticais, além de alguns aspectos culturais. Portanto, ao associar o LDI a "suporte teórico" (P4Q1) e a "fonte de insumo" (Edital) o discurso sobre o LDI reitera essa representação histórica do livro didático, atribuindo a ele o estatuto de conhecimento teórico, científico, verdadeiro e, portanto, inquestionável. Esse poder de verdade investido no LDI pelo discurso que fala sobre ele produz o efeito de que não é necessário ou imprescindível investir na formação do professor, uma vez que o LDI poderá, ao mesmo tempo, ensinar ao aluno e ao professor $^{209}$. Em relação à primeira parte de nossa hipótese $^{210}$, acreditamos que essa representação do livro didático de inglês é já construída pelo discurso sobre o LDI antes mesmo de o discurso do LDI ser conhecido, investindo-lhe poder de verdade.

Os dizeres de P4Q1 parecem ainda reproduzir a imagem de um estado de luta que se estende há algum tempo e que será finalizado com a chegada do LDI, trazendo a vitória ("conquista") dos professores da área. Isto é, os "professores da área" lutam contra o "velho

\footnotetext{
${ }^{208}$ BITTENCOURT, C., 2004, p. 489.

${ }^{209}$ Conforme discutimos ao final do item 1.3 deste trabalho.

${ }^{210}$ A representação do livro didático para o ensino de inglês como discurso de verdade é construída no discurso sobre o LDI. Apesar de não conseguir se manter homogênea, essa construção investe poder no LDI, para que ele funcione como um discurso de verdade.
} 
discurso" (a velha conversa ou a velha desculpa) de que a falta de "suporte teórico" faz da aula uma aula ruim. Luta sem glória, que se estende, que demora, mas que será finalmente bem sucedida; pois já está "previsto o desuso do velho discurso" pela ação salvadora do LDI. P4Q1, ao dizer, investe o LDI de poder suficiente para exterminar esse "velho discurso" e levar a verdade para a aula, suprindo a "falta de um suporte teórico" que a legitimará.

Vejamos agora os dizeres de P5Q1 em resposta à mesma pergunta.

\section{S6 - P5Q1}

Existem dois lados da questão; acredito que para os outros Estados, que não possuem nenhum material didático, é uma evolução - finalmente algo será fornecido aos alunos para a disciplina de língua inglesa; no entanto, para o Estado de São Paulo, surgem muitas dúvidas nós recebemos o Caderno do Aluno, que dependendo da escola, pode ser tanto uma obrigatoriedade, como material de apoio; como o professor trabalhará os dois materiais, se na maioria das vezes, o professor mal dá conta dos conteúdos dos cadernos? O que considero positivo é que esse tipo de material traz $\mathrm{CD}$, o que vem a acrescentar e muito às aulas.

P5Q1 inicia sua resposta à primeira pergunta do questionário acreditando haver apenas dois lados da questão sobre a medida governamental: o caso de São Paulo e o caso dos demais estados brasileiros; ou ainda, de um lado, as escolas amparadas pelo estado que provê materiais, de outro, as escolas que "não possuem nenhum material didático". Para essas, a chegada do LDI é uma "evolução", pois o LDI virá "finalmente" tirar os alunos da "disciplina de língua inglesa" da condição de desprovidos. Temos, novamente, o LDI como responsável pela transformação resultante do movimento de uma ação sobre outra; pois, a adoção levará, através do LDI, à evolução.

O responsável por essa "evolução" é, no entanto, nomeado como "algo"; isto é, "algo será fornecido aos alunos para a disciplina de língua inglesa”. Uma representação de LDI pouco precisa: algo qualquer, desde que seja diferente de nada (diferente de "nenhum material didático"), é já suficiente para tirar os alunos da disciplina de língua inglesa da condição de desprovidos e levá-los à "evolução". Vemos aqui o alto valor simbólico dado ao LDI. Não é preciso conhecê-lo, ler sua proposta, trabalhar seus conteúdos nem exercitar suas atividades com os alunos para saber que ele é capaz de levar a "evolução" para a escola, ao menos às escolas de "outros Estados".

É preciso dizer que P5Q1 não considera ou desconhece o trabalho dos professores de inglês de outros estados brasileiros, que se dedicam à coleta e à elaboração de seus próprios materiais, adaptando-os à realidade de seus alunos e obtendo também ótimos resultados. Apenas como suporte para esse nosso comentário, cito parte da resposta de um professor do 
estado de Pernambuco (P13Q1) que também respondeu ao questionário (Pergunta 2: Que tipo de material você utiliza atualmente? Há quanto tempo você utiliza esse material?).

\begin{abstract}
O material utilizado foi sempre adaptado por mim, coletava dinheiro nas salas para comprar folhas sulfite e xerocava para eles. Era dependioso eu confecionava e selecionava os conteúdos junto a coordenação pedagógica e atividades para as crianças deveriam ser variadas não ser cansativo. [...] E as experiências foram reconhecidas, registradas pela escola em 2008 consegui o primeiro lugar nos projetos escolares. E a partir disso a escola decidiu inserir a disciplina de inglês no $3^{\circ}$ e $4^{\circ}$ e novamente conduzi o barco levando para eles atividades lúdicas e projetos infantis em inglês passando um período de dois anos com essas crianças vindas tanto da zona rural quanto da zona urbana deu muito certo, a escola aprovou meu trabalhou e foi aceito pela comunidade escolar. [sic]
\end{abstract}

Portanto, mesmo sem receber as apostilas, como ocorria com P5Q1, é possível perceber que P13Q1 não se absteve, diante de seu trabalho, de inserir-se em seu contexto social, político e cultural.

Retomando os dizeres de P5Q1, a situação no estado de São Paulo é, então, descrita como o outro lado da questão. Repetimos, aqui, parte de S6.

[...] no entanto, para o Estado de São Paulo, surgem muitas dúvidas - nós recebemos o Caderno do Aluno, que dependendo da escola, pode ser tanto uma obrigatoriedade, como material de apoio; como o professor trabalhará os dois materiais, se na maioria das vezes, o professor mal dá conta dos conteúdos dos cadernos? O que considero positivo é que esse tipo de material traz $\mathrm{CD}$, o que vem a acrescentar e muito às aulas.

Em São Paulo, segundo P5Q1, há a abundância de materiais; tanto que, em seus dizeres, P5Q1 declara não saber como o professor dará conta dos conteúdos. P5Q1 menciona as apostilas, ou cadernos, da proposta curricular do Estado de São Paulo: São Paulo Faz Escola. A preocupação de $\mathrm{P} 5 \mathrm{Q} 1$ parece concernir à possibilidade de o professor não conseguir cumprir ou cobrir todos os conteúdos de ambos, do caderno da proposta e do livro didático, desconhecendo ou não se atentando ao fato de que, pela proposta do PNLD 2011, o LDI substitui esses cadernos.

De todo o modo, os dizeres de P5Q1 apontam à preocupação com os conteúdos programáticos, presentes nos cadernos do São Paulo Faz Escola e no LDI do PNLD ou ainda na falta desses conteúdos, como no caso dos outros estados, como vimos. A pergunta de P5Q1, que não quer resposta - apenas reclama as consequências da abundância de materiais, da suposta "evolução", ou seja, reclama a impossibilidade de trabalhar os dois materiais -, 
acaba por fornecer uma representação redutora de professor como aquele que deve, idealmente, dar "conta dos conteúdos" dos materiais.

Nesses dizeres, o LDI fica, então, representado como o conjunto de conteúdos a serem cobertos. Com conteúdos para serem trabalhados, o LDI é uma "evolução" para quem não possui materiais didáticos e um problema para quem já os tem (os cadernos da proposta do estado de São Paulo). Vemos que, nesses dizeres, os conteúdos dos diferentes materiais são saberes que não se excluem, nem se sobrepõem, sejam eles "uma obrigatoriedade" ou "material de apoio". São verdades que se complementam, pois, para P5Q1, o professor deve dar conta tanto dos conteúdos do LDI quanto dos conteúdos do caderno. Os conteúdos, então, equivalem à matéria presente no livro, ou seja, eles não são vistos como pertencentes ao programa do curso. Se os conteúdos fossem considerados a partir do programa delineado pelo professor ou pela escola, poderiam ser selecionados, buscados em outras fontes e adaptados ao programa de ensino. Porém, aqui, o LDI e também o Caderno do Aluno ditam o que deve ser ensinado, igualando-se ao programa de curso a ser ministrado.

Apesar de P5Q1 se preocupar com o acúmulo de materiais e não saber como administrará a carga de conteúdos, o CD, embora acrescente ainda muito mais ("vem a acrescentar e muito às aulas"), não é um problema; ao contrário, é o aspecto "positivo" do LDI. Parece-nos, então, que, a despeito do que se lê na transparência (ilusória) do discurso, a preocupação de P5 não é exatamente com o acúmulo de conteúdos linguísticos, mas com a necessidade de ter de cumpri-los, dando conta da quantidade de matéria que o livro encerra em sua forma material, em papel, e que deve ser coberta, página por página, nas aulas.

É interessante observar que, neste momento em que as políticas educacionais promovem o acesso das escolas públicas ao mundo virtual, instalando computadores conectados à rede global de informações e outros equipamentos eletrônicos e aplicativos com conteúdos didáticos $^{211}$, o livro didático de inglês em papel é adotado pela primeira vez em âmbito nacional. Parece-nos que o LDI se apresenta, então, como um instrumento de controle, recortando e regulando aquilo que pode e deve ser informado aos alunos e professores e validando os saberes que devem circular como verdades ${ }^{212}$.

\footnotetext{
${ }^{211}$ Computadores do PROUCA - Programa Um Computador por Aluno, regulamentado pelo Decreto $\mathrm{n}^{\mathrm{o}} 7.750$, de 8 de junho de 2012. Disponível em:< http://www.planalto.gov.br/ccivil 03/_Ato20112014/2012/Decreto/D7750.htm>. Acesso em: 20 mai. 2013.

${ }^{212}$ Lembramos que as editoras foram informadas que deveriam oferecer sugestões e informações de acesso para pesquisas, leituras extras etc. A esse respeito, a resenha de uma das duas coleções de inglês aprovadas no PNLD 2011 informa: "Há, também, uma lista com sugestões de leituras extras; a maioria dessas leituras, entretanto, é de textos em português".
} 
Para que possamos perceber o investimento de poder de verdade no LDI nos dizeres de P5Q1, temos ainda que retomar o valor que esse sujeito atribui aos conteúdos a serem ensinados. Assim, P5Q1 representa o LDI como um conjunto de conteúdos, como dissemos acima. Os conteúdos dos cadernos se acumulam com a chegada dos conteúdos do LDI e P5Q1 não sabe "como o professor trabalhará os dois materiais". Vemos que o professor se orienta pelos conteúdos e a aula é regida também por eles. O professor se coloca numa posição submissa aos conteúdos que o dominam e, com a chegada de novos conteúdos, ele se atrapalha, não sabe como trabalhar, não sabe a qual conteúdo se submeter. Os conteúdos o governam. O LDI, como um conjunto de conteúdos, é o que governa o professor, que dita o que fazer na aula. O poder de verdade do LDI, e também dos cadernos, é tão supremo para P5Q1 que ele não vê seu próprio poder de escolha, seu lugar nesse processo, nem sua ação, como se a aula não fosse sua e ele não tivesse controle algum sobre ela.

Assim, o investimento de poder no LDI pode ser percebido nesses dizeres através da própria submissão de P5Q1 ao LDI. Por isso, os professores de outros estados, que não têm o LDI nem os cadernos mencionados, irão, com o LDI do PNLD, evoluir. Percebemos, então, que a adoção do LDI repercute diretamente sobre a ação do professor, resultando na "evolução" daqueles que não têm material algum ou na indecisão sobre o que fazer diante da abundância de materiais.

Analisaremos a seguir algumas respostas dos professores ao segundo questionário de pesquisa, coletado entre 2012 e 2013, após a adoção do LDI. Esse novo contexto, determinado pelo período após a adoção, estabelece novas condições de produção do discurso. Do mesmo modo, as formações discursivas sofrem deslocamentos, pois "aquilo que pode e deve ser dito"213 (PÊCHEUX, M., ([1975] 2009, p. 147) já é também outro. Isto é, diferentemente das respostas dos professores ao primeiro questionário de pesquisa, em que percebemos as incertezas, os anseios e as expectativas sobre as possíveis contribuições geradas pela futura adoção do LDI no imaginário do professor, as respostas ao segundo questionário, de modo geral, carregam a satisfação, mas também as preocupações e os descontentamentos pontuais dos professores respondentes em relação aos aspectos práticos do dia a dia de sala de aula, como o conhecimento de língua exigido, a sequência de conteúdos, a distribuição do material, o cuidado com a manutenção e uso do livro como um objeto material, entre outros.

\footnotetext{
${ }^{213}$ Cf. a definição pecheutiana de formação discursiva.
} 
No segundo questionário, nossa primeira categoria de análise (poder: uma ação sobre outra ação) é analisada nos dizeres que respondem à quinta pergunta, que repetimos abaixo.

5) Na sua opinião, quais os pontos que melhoraram e quais precisam ainda ser melhorados nesse processo de adoção?

A análise dos dizeres das respostas a essa pergunta observa quais ações os sujeitos elegem como já estando presentes e sendo relacionáveis ao processo de adoção do LDI e quais devem ainda ser realizadas. Em resposta à quinta pergunta, P1Q2 informa:

S7 - P1Q2

As aulas ficam mais dinâmicas, pois o prof $^{0}$ não precisa pôr tudo no quadro. Muita coisas necessárias de acordo com a série estão no livro, mas como já falei acho pouca a gramática (os exercícios.)

Vemos que P1Q2 considera a dinâmica das aulas como um dos pontos que melhoraram após a adoção do LDI. Nesse dizer, há a aparente atribuição da consequência direta para o maior dinamismo das aulas à adoção do LDI. Porém, a explicativa que segue essa primeira afirmação ("pois o prof o. não precisa pôr tudo no quadro") restabelece o movimento de uma ação sobre outra. Ou seja, a ação de se adotar o LDI age sobre a ação do professor, que já "não precisa pôr tudo no quadro" e, como consequência, "as aulas ficam mais dinâmicas".

Após essa primeira frase, o dizer de P1Q2 nos informa sobre sua avaliação dos conteúdos do LDI. Como já comentamos, a grande maioria das respostas ao segundo questionário se concentra em observações e avaliações sobre os conteúdos, as atividades e até ao preço do livro didático em relação à qualidade ${ }^{214}$. Contrastando com as respostas ao primeiro questionário, em que os dizeres mobilizavam representações de LDI de acordo com o imaginário dos professores, essas observações de caráter mais prático fornecidas nas respostas ao segundo questionário são esperadas, uma vez que os professores já trabalham com o LDI do PNLD 2011 em sua rotina de aula.

Até por isso, é possível observar, nos dizeres dos respondentes ao segundo questionário, que a abordagem prevista pelo PNLD 2011 não é sempre familiar a muitos

\footnotetext{
${ }^{214}$ Também em resposta à quinta pergunta, P18Q2 informa: "Talvez um caráter mais critico, com a adoção de um livro mais eficaz e não um mais barato para os cofres públicos" [sic].
} 
desses professores. Apesar de o Programa não determinar uma única abordagem metodológica, o subitem 3 do item 2.1.5 do Edital de Convocação diz:

\subsubsection{Observância das características e finalidades específicas do manual do professor e adequação da coleção à linha pedagógica nele apresentada [...]}

3. relacionar a proposta didático-pedagógica da coleção aos principais documentos públicos nacionais que orientam o ensino fundamental no que diz respeito ao componente curricular em questão;

Entendemos, então, que a proposta didático-pedagógica do LDI do PNLD 2011 deve se orientar pelos Parâmetros Curriculares Nacionais (PCN-1998), terceiro e quarto ciclos do Ensino Fundamental, para a disciplina de língua estrangeira. O terceiro e o quarto parágrafos do texto da apresentação desses PCN dizem:

Duas questões teóricas ancoram os parâmetros de Língua Estrangeira: uma visão sociointeracional da linguagem e da aprendizagem. O enfoque sociointeracional da linguagem indica que, ao se engajarem no discurso, as pessoas consideram aqueles a quem se dirigem ou quem se dirigiu a elas na construção social do significado. É determinante nesse processo o posicionamento das pessoas na instituição, na cultura e na história. Para que essa natureza sociointeracional seja possível, o aprendiz utiliza conhecimentos sistêmicos, de mundo e sobre a organização textual, além de ter de aprender como usá-los na construção social do significado via Língua Estrangeira. A consciência desses conhecimentos e a de seus usos são essenciais na aprendizagem, posto que focaliza aspectos metacognitivos e desenvolve a consciência crítica do aprendiz no que se refere a como a linguagem é usada no mundo social, como reflexo de crenças, valores e projetos políticos.

No que se refere à visão sociointeracional da aprendizagem, pode-se dizer que é compreendida como uma forma de se estar no mundo com alguém e é, igualmente, situada na instituição, na cultura e na história. Assim, os processos cognitivos têm uma natureza social, sendo gerados por meio da interação entre um aluno e um parceiro mais competente. Em sala de aula, esta interação tem, em geral, caráter assimétrico, o que coloca dificuldades específicas para a construção do conhecimento. Daí a importância de o professor aprender a compartilhar seu poder e dar voz ao aluno de modo que este possa se constituir como sujeito do discurso e, portanto, da aprendizagem.

Há, portanto, a indicação da perspectiva sociointeracional para o ensino de línguas estrangeiras nos PCN que subsidiam a proposta didático-pedagógica do PNLD 2011. Para o componente língua estrangeira moderna, o Programa também deseja implantar uma abordagem de ensino de línguas voltada à comunicação e, para isso, exige dos titulares de 
direito autoral a elaboração de coleções que ofereçam o equilíbrio na prática das quatro habilidades da língua (ler, falar, escrever, ouvir) e o CD como material complementar obrigatório. Porém, o conhecimento dos professores e também dos alunos dos $7^{\circ}, 8^{\circ}$ e $9^{\circ}$ anos e as técnicas exigidas por esse trabalho com as quatro habilidades são tomados como pressupostos pelo Programa, pois não houve qualquer treinamento nem preparação junto aos professores para que esse trabalho pudesse ser realizado. Ou seja, partiu-se do princípio de que todos os professores da escola pública brasileira soubessem trabalhar com a abordagem sociointeracionista, que tivessem experiência no uso de técnicas de práticas de ensino que correspondessem a essa perspectiva metodológica e que também os alunos, ao menos os não iniciantes, já estivessem acostumados com esses procedimentos na rotina da aula. Para isso, considerou-se suficiente detalhar, no manual do professor, os procedimentos práticos e informar ao professor sobre os princípios da abordagem adotada pela coleção. No entanto, as respostas dos professores ao segundo questionário de pesquisa mostram que esse detalhamento não foi suficiente. Como apoio a essa observação, destacamos alguns dizeres abaixo:

- Acho que falta um pouco mais de gramática. (P12Q2)

- Não estou [satisfeito] por motivos e questões relacionadas ao vocabulário no final do livro, o que não ajuda muito, uma vez que tem poucas palavras. (P18Q2)

- Não está contribuindo muito por não contemplar o alinhamento dos conteúdos impostos. (P5Q2)

- As vantagens se realizam na oportunidade de o aluno ter maior acesso á textos e exercícios em língua inglesa. Também na sequenciação e fixação do conteúdo. (P15Q2)

- Alguns livros tem textos longos demais e isso acaba dificultando tanta a pronúncia como a tradução. (P6Q2)

- Acho poucos exercícios de gramática no livro. (P1Q2)

É preciso considerar que uma perspectiva tradicional sobre o ensino de língua estrangeira - que privilegia a noção de ensino como a disponibilização sequencial de conteúdos, a prática exaustiva da gramática por meio de exercícios metódicos, a tradução como possibilidade de representação literal da língua e desvinculada da cultura etc. - não pode ser totalmente suprimida, apagada, sem deixar raízes, com a chegada de outra 
perspectiva. Portanto, não é incomum que as respostas ao segundo questionário tragam essas reivindicações.

As questões levantadas por esses professores-respondentes concorrem para a formação do contexto educacional em que o primeiro livro didático de inglês foi adotado nacionalmente. Nesse quadro, vê-se que o detalhamento das informações no manual do professor não pôde suprir as necessidades do professor e não poderá substituir o investimento no professor: na sua formação, sua especialização, suas condições de trabalho.

Para essa mesma quinta pergunta do questionário, outro respondente escreve:

S8 - P2Q2

SE BEM DISTRIBUÍDO E NÃO HOUVER FALTA NAS ESCOLAS, O LIVRO IRÁ CONTRIBUIR PARA O MELHOR APERFEIÇOAMENTO DE TODOS OS ENVOLVIDOS NO PROCESSO DE ENSINO.

Nesse dizer, P2Q2 impõe duas condições para que haja o "melhor aperfeiçoamento": que o LDI seja bem distribuído e não falte. Isto é, para P2Q2, a presença física, material, do LDI já será suficiente para contribuir ao aperfeiçoamento. Notamos, então, que esse dizer de P2Q2 atribui poder de verdade ao LDI ao mesmo tempo em que produz o efeito de dessimbolização do LDI, representando-o como um objeto de troca que sustenta apenas seu valor venal. Esse efeito, como já discutimos, funciona de modo retroverso, pois a ilusória dessimbolização trabalha exatamente sobre a memória do valor simbólico do objeto. Desse modo, percebemos que o efeito de dessimbolização reforça o poder de verdade do LDI nesse dizer de P2Q2, pois a plena distribuição e a presença do LDI nas escolas já contribuirá ao processo de ensino.

Podemos ainda observar o movimento de uma ação sobre outra em S8; pois, as ações de distribuir o LDI e não deixá-lo faltar incidem sobre as ações daqueles que estão envolvidos no processo de ensino, contribuindo ao seu aperfeiçoamento.

Em resposta à mesma pergunta, $\mathrm{P} 3 \mathrm{Q} 2$ diz:

S9 - P3Q2

A adoção do livro didático contribuiu para valorizar e ressignificar o ensino de L. Inglesa, facilitando o trabalho do prof. e a aprendizagem do aluno. 
Vemos que esse sujeito também atribui à adoção de um LDI independente de qual coleção é adotada, o poder de contribuir para a valorização e a ressignificação do ensino de inglês. Portanto, nos dizeres de P3Q2, vemos um longo movimento de uma ação sobre outra que podemos representar graficamente como sendo:

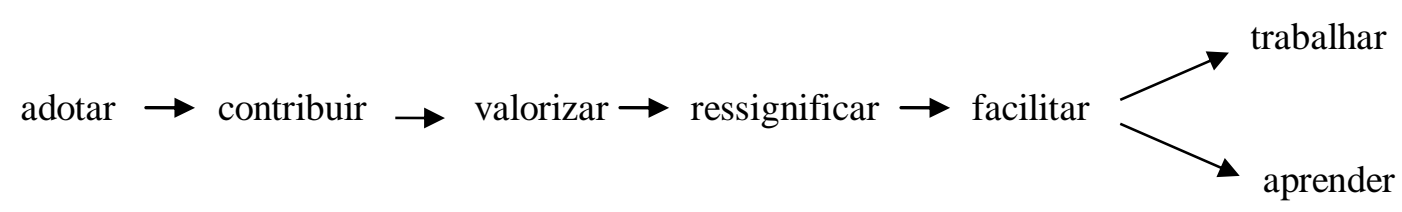

Contudo, não sabemos de que modo, para P3Q2, a adoção contribuiu nesse processo. Isso porque o verbo contribuir pressupõe um coadjuvante; um outro elemento que fornece a ajuda complementar necessária para a realização de algo. Como efeito, percebemos que esse outro elemento fica apagado nesse dizer que declara apenas a "adoção do livro didático" como sujeito gramatical de contribuir. Podemos dizer que, em S9, o apagamento desse segundo elemento (ou outros mais) é completo, pois, textualmente, não remete a pressupostos e, discursivamente, não mobiliza qualquer não-dito nem pré-construído. O apagamento total foraclui o segundo elemento que indicaria o responsável por complementar a ação de contribuir, atribuindo, assim, um poder redobrado ao único sujeito gramatical reconhecido no dizer de P3Q2: "a adoção do livro didático".

É interessante observar ainda, na escrita de P3Q2, abreviações para apenas alguns elementos: língua inglesa é abreviada como L. Inglesa e professor como prof., mas o livro didático não é abreviado (LD ou apenas livro) nem omitido (a adoção [ ] contribuiu). Esse pequeno detalhe pode reforçar discursivamente o poder do livro didático, mesmo generalizado. Isto é, a adoção de um livro didático qualquer desencadeia o movimento na sequência de uma ação sobre outra ação.

Para P4Q2, o processo de adoção trouxe apenas melhoras. Vejamos o breve dizer abaixo.

$\mathrm{S} 10-\mathrm{P} 4 \mathrm{Q} 2$

Melhoraram pq os alunos podem ler e estudar em casa também.

Mesmo que a pergunta cinco peça pela indicação dos pontos que melhoraram e outros que precisariam ainda ser aprimorados no processo de adoção, P4Q2 informa apenas as consequências de alguma melhoria, mas não determina exatamente o que melhorou. Isto é, os 
"pontos que melhoraram" não são determinados por P4Q2 e se apresentam na materialidade linguística como um sujeito gramatical oculto. Desse modo, esse dizer parece desejar enfatizar as consequências desses "pontos que melhoraram": "os alunos podem ler e estudar em casa também"; ao mesmo tempo em que mantém oculto o sujeito do verbo "melhoraram".

Também nesse dizer, é possível perceber o movimento de uma ação sobre outra; pois, "os pontos que melhoraram" incidiram sobre as ações dos alunos que, agora, "podem ler e estudar em casa”. Entende-se, portanto, que os alunos podem ler e estudar fora da sala de aula porque agora têm um livro de inglês que pode ser levado para casa. Em outros termos, aquilo que possibilita essas ações dos alunos é o livro didático, que recebe, portanto, o investimento de poder necessário para funcionar como uma verdade mesmo ficando oculto no dizer.

\subsection{Dizeres do discurso midiático}

O segmento midiático do nosso corpus de pesquisa é composto por matérias publicadas on line sobre os livros de inglês do PNLD 2011. Como nosso foco era obter um grande número de artigos que, de algum modo, tratassem da adoção do LDI proposta por esse programa governamental, as matérias não foram selecionadas pelo tipo de agência publicitária ou fonte de informação. Assim, há matérias de agências de notícias de repercussão nacional e de agências locais, matérias de sites de escolas públicas e de associações, blogs, portais de grupos editoriais e outros. Por isso, informaremos a fonte do excerto e as datas de publicação e de acesso em cada sequência discursiva que analisamos.

De modo geral, a grande maioria dos textos encontrados tem como fonte órgãos oficiais (MEC, FNDE ${ }^{215}$, Secretarias Estaduais de Educação) ou seus representantes. Esse fato talvez tenha contribuído para que os textos veiculados on line se apresentassem como reproduções mais ou menos idênticas entre si. É importante ainda ressaltar que a pesquisa por textos midiáticos que tratassem da adoção do primeiro LDI no Brasil pelo PNLD resultou em grandes quantidades de artigos; porém, tais artigos se referiam aos mesmos informes publicados pelos órgãos oficiais, sem alterações significativas, como veremos a seguir. Portanto, a quantidade de textos encontrados não favoreceu a constituição de um corpus variado e mais abrangente. A seguir, trataremos de alguns desses textos.

Sob o título Alunos da rede pública receberão livros de inglês e espanhol, dezenas de textos foram divulgados por agências on line entre os meses de setembro e outubro de 2008. No site da Abrelivros ${ }^{216}$ - Associação Brasileira de Editores de Livros Escolares - o

\footnotetext{
${ }^{215}$ MEC, Ministério da Educação; FNDE, Fundo Nacional de Desenvolvimento da Educação.

${ }^{216}$ Disponível em: 〈http://www.abrelivros.org.br〉. Acesso em: 23 out. 2010.
} 
leitor do artigo com o título mencionado acima é informado sobre a origem do texto: "Escrito por Portal MEC - Assessoria de Comunicação Social do FNDE”. Em geral, as agências de notícias publicam o texto na íntegra e citam alguma fonte, mesmo que imprecisa como: "Fonte: Governo Federal", “Com informações do MEC”, "Fonte: http://www.fnde.gov.br", "Agência: Brasil" etc.. Mas, muitas apenas publicam recortes do texto e não informam a fonte ou, ainda, assumem a autoria do texto: "por: Da redação" foi a fonte encontrada no jornal Dia a dia da Agência de notícias Primeira Hora para o mesmo texto divulgado por tantas outras agências.

Todas essas ações são, de algum modo, esperadas e não nos causam estranhamento justamente por serem características do funcionamento do discurso midiático. Porém, o distanciamento da opinião jornalística em relação ao acontecimento (a inclusão de livros de LE no PNLD 2011), abdicando do lugar de questionamento que a mídia adota tradicionalmente, contentando-se em reproduzir a fala oficial, é surpreendente. Esse afastamento pode produzir o sentido de que a chegada do livro didático de língua estrangeira na escola pública não é de interesse da mídia ou não causa impacto algum que pudesse instigar investigações jornalísticas. Por outro lado, é preciso considerar que é através da mídia que o discurso oficial se torna público. Sendo assim, a reprodução do discurso oficial pela mídia, sem contestação ou questionamento, pode produzir o sentido de que não há nada ali a ser questionado; ou melhor, não há nada ali que a sociedade pudesse questionar ou contestar. Nesse caso, o discurso da mídia valida o discurso oficial perante a sociedade, tranquilizando-a e apagando qualquer ponto de discórdia que o discurso oficial pudesse suscitar.

Selecionamos, abaixo, apenas o primeiro parágrafo do texto sob o mesmo título divulgado por três agências de notícias. Em cada um, sublinhamos a informação sobre a palestra, pois esse é o único lugar do texto em que encontramos algumas diferenças.

S11 - Agência Terra: http://noticias.terra.com.br/educacao/interna. Publicado em 15 de agosto de 2008. Acesso em 22 de outubro de 2010.

Os alunos dos anos finais do ensino fundamental público passarão a receber livros didáticos de inglês e espanhol a partir de 2011. A informação é do presidente do Fundo Nacional de Desenvolvimento da Educação (FNDE), Daniel Balaban, durante palestra realizada na $20^{\mathbf{a}}$ Bienal Internacional do Livro de São Paulo, no Pavilhão de Exposições do Anhembi.

S12 - Agência Primeira Hora: http://www.primeirahora.com.br. Publicado em 15 de agosto de 2008. Acesso em 23 de outubro de 2010. 
Os alunos dos anos finais do ensino fundamental público passarão a receber livros didáticos de inglês e espanhol a partir de 2011. A informação é do presidente do Fundo Nacional de Desenvolvimento da Educação (FNDE), Daniel Balaban, durante palestra realizada na $20^{\mathrm{a}}$ Bienal Internacional do Livro de São Paulo, no Pavilhão de Exposições do Anhembi.

S13 - Agência Globo.com: http://g1.globo.com/. Publicado em 15 de agosto de 2008. Acesso em 23 de outubro de 2010.

Os alunos dos anos finais do ensino fundamental público passarão a receber livros didáticos de inglês e espanhol a partir de 2011. A informação é do presidente do Fundo Nacional de Desenvolvimento da Educação (FNDE), Daniel Balaban, durante palestra feita na manhã desta sexta-feira (15) na $20^{a}$ Bienal Internacional do Livro de São Paulo, no Pavilhão de Exposições do Anhembi.

Essa última agência incluiu, na parte que grifamos, mais informações sobre o dia da palestra, sem outras alterações em relação a S11 e S12, que se igualam. O texto base foi fornecido pela Assessoria de Comunicação Social do Fundo Nacional de Desenvolvimento da Educação (FNDE), que reproduzimos abaixo.

S14 - FNDE: http://www.fnde.gov.br. Publicado em 15 de agosto de 2008. Acesso em 23 de outubro de 2010.

Alunos da rede pública receberão livros de inglês e espanhol a partir de 2011 Sex, 15 de agosto de 2008

ASCOM-FNDE (Brasília) - Os alunos dos anos finais do ensino fundamental público passarão a receber livros didáticos de inglês e espanhol a partir de 2011. A informação foi dada pelo presidente do Fundo Nacional de Desenvolvimento da Educação (FNDE), Daniel Balaban, durante palestra feita na manhã de hoje, 15 , na $20^{\mathrm{a}}$ Bienal Internacional do Livro de São Paulo, no Pavilhão de Exposições do Anhembi.

Temos, então, S11 e S12 com formulações idênticas: "durante palestra realizada na 20a Bienal Internacional do Livro", porém menos detalhadas que em S14. Já S13, com "durante palestra feita na manhã desta sexta-feira (15) na $20^{\text {a }}$ Bienal Internacional do Livro", se aproxima dos detalhes fornecidos pela agência da S14: "durante palestra feita na manhã de hoje, 15, na $20^{\text {a }}$ Bienal Internacional do Livro". Percebemos que essa informação sobre a data do evento é o lugar que aceita variações, sem que o conteúdo principal da notícia seja alterado e sem o comprometimento da agência de notícias. Esses detalhes, mesmo que não sejam informados, como em S11 e S12, se necessários, poderiam ser pesquisados pelo leitor da 
notícia a partir da informação "20 Bienal Internacional do Livro de São Paulo", constante em todos os textos.

Portanto, os textos dessas agências, dentre outras tantas, apenas reproduzem o texto oficial, com alterações mínimas e sem comprometimento. Esse procedimento da mídia parece apontar à falta de preocupação de estar apenas reproduzindo uma informação. Não há também a preocupação de marcar a heterogeneidade, os dizeres do outro, com aspas, como se costuma fazer em citações. Parece ocorrer, então, um tipo de tomada de posse de discurso: do oficial para o midiático; pois, não há marcas textuais de heterogeneidade enunciativa que, neste caso, se reduz à intertextualidade.

Mesmo que algumas agências de notícias forneçam a fonte de informação, a falta de marcas de heterogeneidade enunciativa produz o efeito de que o texto em si foi escrito pela própria agência. Esse procedimento pode também ser encontrado em textos sobre as outras fases do PNLD 2011, sem que haja o posicionamento crítico ou, ao menos, investigativo esperado em dizeres do discurso midiático. Nesses casos, a mídia cumpre seu papel de informar, mas se isenta de se posicionar criticamente sobre um fato histórico: a entrada em massa do LD de língua estrangeira na escola pública. De todo o modo, nos parece que, ao repetir, a mídia ecoa a ação dos órgãos públicos, dando prosseguimento ao deslizar de ações no movimento de uma ação sobre outra.

A representação de LDI no discurso midiático percebida a partir da falta de posicionamento crítico e, possivelmente, de interesse da mídia em relação a esse material é que, talvez, o LDI não seja considerado para além de sua função material, tão necessário e comum como a merenda, o giz, o quadro-negro, as carteiras etc.. Essa representação de LDI como um suprimento ou objeto apenas material desconsidera seu caráter simbólico, apagando traços essenciais e que fazem toda a diferença na aula e no ensino de modo geral. Um objeto destituído de sua função simbólica e de seu potencial de poder e verdade.

Porém, como argumentamos, essa desconsideração do valor simbólico, ou essa dessimbolização, é apenas efeito do trabalho da ideologia. Pois, ao mesmo tempo em que aparentemente se distancia da ideologia, se ausentando de posicionamento crítico, ao reproduzir o discurso oficial, o discurso da mídia concorda com ele e, além disso, rende-lhe mais força pela repetição, como re-escritura, e por sua publicação sob o nome da agência de notícias. Sendo assim, a mídia se ausenta de autoria e criticidade, mas reforça o discurso que coloca o livro didático no jogo de poder-saber que circula na sociedade.

Considerando-se a veiculação da notícia pela mídia para informar a sociedade e, neste caso, a repetição do discurso oficial, poderíamos dizer, à primeira vista, que a representação 
do LDI que chega à sociedade pela mídia é idêntica à representação do LDI construída no/pelo discurso oficial. Como vimos em S1, o LDI é representado no/pelo discurso oficial como destituído de valor simbólico através do funcionamento do efeito ideológico de dessimbolização. Porém, ao ecoar o discurso oficial, a mídia o legitima junto à sociedade, produzindo o efeito de que não há nada ali a ser investigado ou criticado; uma vez que esse seria também, além de informar, o papel da mídia: apontar possibilidades de questionamento.

Além disso, a falta de especificidade da representação do LDI acaba também por marcá-lo como um livro didático, diríamos, genérico. Isto é, o LDI é discursivisado no discurso midiático não exatamente como sendo um livro didático qualquer, mas o livro didático cuja representação habita o imaginário da sociedade; portanto, um livro completo, eficaz e perfeito. Também a falta de informação sobre o papel do LDI nesse momento na escola, fruto do posicionamento apenas reprodutor da mídia, produz o sentido de que aquilo que um livro didático pode e deve fazer é já naturalizado na sociedade. Há, aí, um grande investimento de poder no LDI, como se ele, esse LDI genérico, fosse capaz de dar conta daquilo que a sociedade espera de um livro didático completo, eficaz e perfeito: fazer com que todos os alunos brasileiros do $6^{\circ}$ ao $9^{\circ}$ ano da escola pública saibam uma língua estrangeira. Assim, o discurso midiático, pela repetição do discurso oficial, se isenta de se responsabilizar por essas impossibilidades perante a sociedade.

Mesmo nessa repetição podemos perceber o movimento de uma ação sobre outra; pois, o discurso oficial sobre o LDI, ao falar à mídia, constrói a representação de LDI que deve ser passada adiante. Ou seja, a ação, aqui, consiste em o discurso oficial construir uma imagem de LDI que atuará sobre a ação legitimadora e tranquilizadora da mídia. O discurso midiático, por sua vez, validará essa imagem de LDI, atuando sobre a ação da sociedade, aceitando e não questionando essa imagem que recebe pronta e acabada. Esse processo instiga-nos a pensar o funcionamento do discurso oficial nos termos de Courtine; isto é, observar os "fluxos tecnológicos de sua circulação, o estado líquido das discursividades políticas contemporâneas" (COURTINE, J-J., 2008, p. 16). Isso porque, com essa multiplicação muitas vezes idêntica e outras com poucas alterações, é como se fosse possível observar, para além da transparência ilusória do discurso, um gesto de consentimento ou incentivo das assessorias e agências de comunicação oficiais à ação "copia e cola" da mídia, tão atual no meio digital, como um plágio consentido que tanto assegura as palavras quanto afasta o questionamento. 


\section{Considerações sobre o capítulo}

A análise dos dizeres percebeu o efeito de um conjunto de ações sobre outras ações funcionando no discurso sobre o LDI. Legitimado socialmente para o controle de práticas, o discurso oficial estabelece, através de suas ações, as ações de outros, como vimos nos dizeres analisados. Para além de produzir condições para que o outro aja, o discurso oficial já demarca os limites do território em que esse outro (titulares de direito autoral, professores etc.) agirá, delimitando também o escopo dessa atuação.

O discurso profissional nos possibilitou perceber, como efeito, o impacto direto da ação dos órgãos públicos sobre a ação do professor: a ação governamental de adotar o LDI facilita a vida do professor (P1Q1 e P3Q2), ajuda bastante (P2Q1), melhora a dinâmica das aulas (P1Q2), aperfeiçoa o ensino (P2Q2), aumentando o interesse dos alunos e facilitando o aprendizado (P3Q1 e P4Q2). Além disso, essa ação governamental provê o professor com o "suporte teórico" (P4Q1), levando a "evolução" aos estados desprovidos (P5Q1). No discurso profissional cujos dizeres foram coletados antes da adoção, o LDI é representado como aquilo que preencherá a falta que o professor percebe existir na aula, no ensino de inglês da escola pública, na escola perante os professores de outras disciplinas e nos estados "desprovidos" de recursos. Assim, a ação de adotar o LDI incidirá sobre a ação do professor, tornando-a completa e fácil. Esse movimento de uma ação sobre outra foi percebido também nos dizeres dos sujeitos que responderam ao segundo questionário de pesquisa. $\mathrm{O}$ foco principal desses dizeres recai, agora, sobre a presença física do LDI na escola. Esse olhar sobre o LDI como um objeto físico, concreto, acaba enfraquecendo o caráter simbólico do livro didático nos dizeres analisados, como se esse objeto pudesse ser desprovido de simbologia.

$\mathrm{Na}$ reprodução do discurso oficial pelos dizeres do discurso midiático, percebemos que o efeito de repasse parece desejar garantir a imparcialidade da notícia, mas que, no entanto, contribui para legitimar o discurso oficial junto à sociedade, dispersando o olhar do leitor para longe da possibilidade de questionamentos. Nesses dizeres do discurso midiático que analisamos, a representação do LDI como um objeto dessimbolizado reforça a garantia de que não é preciso questionar porque não há nada para ser questionado. Apontamos a possibilidade de essa reprodução resultar de um funcionamento já previsto pelo discurso oficial que trabalha no sentido de garantir a repetibilidade das palavras para ilusoriamente conter o sentido e assegurar o não questionamento. As consequências suscitadas por esse efeito que percebemos parecem-nos alinhadas à perspectiva de Pêcheux sobre a tarefa da $\mathrm{AD}$ : mais do que dar respostas, propor questões. Nesse caso específico, a transparência que a repetibilidade do 
texto tenta garantir parece funcionar nos moldes da sociedade de controle: um controle firme e contundente exercido em meio aberto; pois, como disse Deleuze ([1990] 2008, p. 216), "Face às formas próximas de um controle incessante em meio aberto, é possível que os confinamentos mais duros nos pareçam pertencer a um passado delicioso e benevolente".

Neste capítulo, o movimento de uma ação sobre outra foi percebido no discurso sobre o livro didático de inglês. Contudo, esse movimento parece percorrer uma só direção; isto é, a ação governamental de adotar o LDI sobre: a ação de produzi-lo (através dos titulares de direito autoral), a ação de utilizá-lo (por meio dos professores) e a ação de legitimá-lo (via mídia). Um movimento com orientação contrária (da ação de utilizá-lo à ação de adotá-lo etc.) poderia se configurar como uma ação de resistência que, já intimamente prevista, aconteceria dentro mesmo dessa relação de poder. Porém, esse movimento contrário, embora previsto pelo Programa ${ }^{217}$ e possível em sua capilaridade anônima ${ }^{218}$, não é livremente assegurado ao professor, pois há o esforço de se manter a orientação desse movimento sob controle. O funcionamento detalhado desse modo de controle pode ser observado na insistência do discurso sobre a escolha do LDI pelo professor, como veremos a seguir, ao mesmo tempo em que ele, o professor, é mantido até o fim como uma pessoa que age $e^{219}$ (FOUCAULT, M., 1982, p. 220).

\footnotetext{
${ }^{217}$ Como vimos em 2.1, a não adesão ao programa de adoção de materiais didáticos é prevista pelo PNLD. Para isso, basta não assinar o Termo de Adesão. Nesse caso, a escola não receberá quaisquer materiais didáticos. Para a não adesão ao programa em apenas algumas disciplinas, a escola deve assinar o Termo de Adesão e informar no Registro de Escolha ou em declaração própria que não deseja receber os materiais para tais disciplinas.

${ }^{218} \mathrm{Na}$ análise do discurso oficial que realizamos, esse movimento contrário não nos parece ser considerado como algo que as escolas e os professores pudessem desejar. Mesmo assim, sabemos, pelas respostas aos questionários de pesquisa, que muitos professores e escolas não aderiram ao Programa.

${ }^{219}$ No sexto capítulo, tratamos da análise dos dizeres que representam o professor como uma pessoa que age.
} 


\section{CAPÍtULO 5}

\section{VERDADE: A CONSTRUÇÃO DISCURSIVA DO SABER NO DISCURSO SOBRE O LDI}

Nossa segunda categoria de análise foi estabelecida a partir da definição foucaultiana de verdade. Nosso objetivo é perceber se e como o discurso sobre o LDI o representa como um saber, como uma verdade, conforme definiu Michel Foucault (FOUCAULT, M. [1979] 2004, p. 14), ou seja, sendo o "conjunto" (resultado ou produto) "de procedimentos regulados para a produção, a lei, a repartição, a circulação e o funcionamento dos enunciados".

É importante ressaltar que, com essa definição, Foucault afasta a noção de saber de uma concepção naturalista, como se fosse algo pré-existente ao sujeito e que pudesse ser apropriado, tomado para si. O saber é, portanto, visto como uma construção discursiva engendrada pelo poder como um conjunto de procedimentos. No movimento circular característico da relação entre poder e saber, o saber, como um conjunto de procedimentos, é regulado pelo poder para que sejam produzidos os enunciados e para que eles funcionem de acordo com a sociedade em que são estabelecidos.

Neste estudo, pensamos que o discurso sobre o LDI representa esse livro como uma verdade, um saber; portanto, o LDI comporta um conjunto de procedimentos que devem ser regulados para que os enunciados funcionem e circulem, sejam reproduzidos, repartidos e estabeleçam sua lei. Como discutimos anteriormente, tomaremos como pressuposto os estudos de outros pesquisadores ${ }^{220}$ que têm o discurso do LDI como objeto e buscaremos especificamente nos dizeres do discurso sobre o LDI momentos em que possamos perceber o controle que deseja regular o funcionamento do LDI, para garantir os enunciados que circulam socialmente.

\subsection{Dizeres do discurso oficial}

Iniciaremos com a análise dos dizeres do discurso oficial. No Edital de Convocação, documento com as normas de publicação dirigido às editoras para a elaboração das coleções didáticas, o último subitem do título Do Processo de Avaliação e Seleção das Obras lemos:

\footnotetext{
${ }^{220}$ Cf. CORACINI, M. J., 1999.
} 


\section{S15}

\subsection{Da escolha das obras}

Os professores, em consenso, com base nas resenhas contidas no Guia de Livros Didáticos, escolherão as coleções que serão utilizadas pelos alunos.

Nessa sequência discursiva, vemos que os professores de cada escola devem chegar a um consenso sobre quais coleções adotar para seus alunos. Poderíamos dizer que um consenso é o resultado de uma discussão. Supõe-se, então, que os professores de língua inglesa de uma escola examinem as coleções $^{221}$ pré-selecionadas pelos especialistas avaliadores, discutam as vantagens e desvantagens de cada uma e, finalmente, cheguem a um resultado. Porém, como informa o Edital, esse consenso deverá ter como base as resenhas, ou seja, ser mediado pelas opiniões dos especialistas. A escolha será regulada pelos dizeres das resenhas e, em última instância, pelos órgãos governamentais, que as aprovaram e as publicaram no Guia. Portanto, parece-nos, já aqui, que esse dizer sobre o LDI, como o livro que deverá ser escolhido pelos professores a partir do consenso guiado pelas resenhas, corrobora nossa segunda categoria de análise. Ou seja, nesse dizer, o LDI é discursivisado como aquilo que materializa ou comporta o conjunto de procedimentos que foram previamente aprovados e, portanto, regulados. Assim, não é a escolha do livro feita pelos professores que regulará os enunciados que o LDI encerra; pois esses já foram pré-aprovados e regulados, não pelos professores em consenso, mas por um longo e minucioso processo de seleção, culminando nos dizeres das resenhas publicadas e aprovadas pelos órgãos públicos envolvidos.

$\mathrm{Na}$ materialidade linguística, percebemos que há duas incisas separando o sujeito gramatical do verbo:

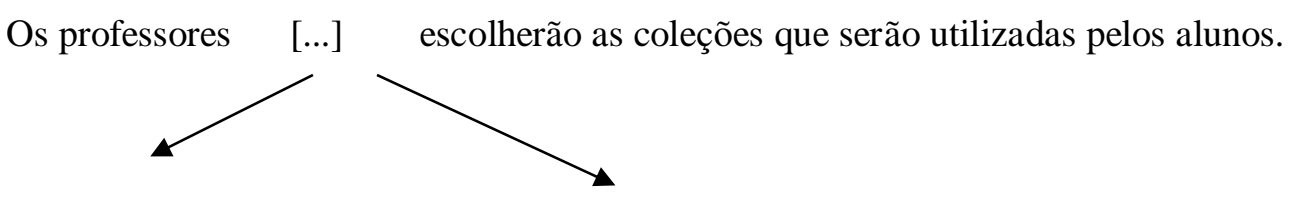

, em consenso, com base nas resenhas contidas no Guia de Livros Didáticos,

${ }^{221}$ É previsto pelo Programa que as escolas recebam, além do Guia de Livros Didáticos, os exemplares das coleções pré-selecionadas, para que os professores as examinem antes de fazerem a escolha. Como veremos adiante em 5.1.3, alguns respondentes ao segundo questionário (P7Q2 e P11Q2) declaram que esse recebimento nem sempre ocorreu ou foi parcial. 
Como efeito, percebemos que essas incisas, ao estabelecerem um espaço de adiamento entre o sujeito gramatical e o verbo, estabelecem também, na materialidade discursiva, o adiamento da ação de escolher ("escolherão") atribuída aos professores nesse discurso. Em outros termos, antes de "Os professores" fazerem a escolha das coleções, eles devem entrar "em consenso" e terem como "base" as resenhas. Para isso, portanto, os professores deverão reunir-se, discutirem sobre as coleções, lerem e discutirem as resenhas do Guia, antes de finalizarem sua escolha. Esse efeito de adiamento da ação dos professores parece corroborar o funcionamento dos princípios moduladores que garantem o adiamento do fim, exigindo atualizações contínuas ("em consenso"; "com base nas resenhas") e assegurando o controle das ações.

Apesar do atrelamento entre a escolha feita pelo professor e as informações das resenhas contidas no Guia, o dizer que ilude sobre a escolha ser realmente do professor percorre os textos do Edital de Convocação e do Guia com insistência. Destacamos, abaixo, outros excertos do Edital e também do Guia onde esse dizer insiste.

\subsubsection{A escolha nos dizeres do Edital de Convocação}

Num primeiro olhar, os dizeres parecem atribuir aos professores a tarefa de escolher o livro didático a partir de seus próprios critérios. Porém, com a análise e na dispersão do discurso, podemos perceber que outros efeitos são produzidos. Vejamos como esses dizeres do Edital primeiramente produzem e depois desconstroem o sentido de escolha feita pelos professores das escolas.

S16

\section{DO PROCESSO DE HABILITAÇÃO}

Com base na escolha das coleções pelos professores, o Fundo Nacional de Desenvolvimento da Educação - FNDE procederá à habilitação dos titulares de direito autoral.

Inicialmente, em S16, há a informação que as editoras (os titulares de direito autoral) vencedoras do processo serão habilitadas pelo FNDE para a produção e venda do material. Porém, o FNDE apenas habilitará as editoras cujas coleções forem escolhidas pelos professores. Portanto, no discurso desse documento, a escolha do professor exerce influência direta em relação à habilitação das editoras cujas coleções foram pré-selecionadas pelo MEC. 


\subsection{Da aquisição}

Com base na escolha informada pelas escolas e nas projeções do Censo Escolar realizado pelo Instituto Nacional de Estudos e Pesquisas Educacionais Anísio Teixeira - INEP, o FNDE/MEC convocará, por intermédio de Comissão Especial de Negociação instituída para esse fim, os titulares de direito autoral habilitados para proceder à negociação de preços.

Em S17, vemos que a negociação de preços pelo FNDE/MEC também terá como base a escolha das coleções que será feita pelos professores, pois será informada pelas escolas. $\mathrm{O}$ número de exemplares será estimado pelo INEP, tendo as projeções do censo como referência para cálculo. Esse dizer relaciona a escolha das coleções aos gastos que dela recorrerão, apontando à responsabilidade e à importância material dessa escolha.

S18

10.8. As etapas do processo referente ao PNLD 2011 estarão sob a integral responsabilidade: [...]

10.8.4. dos Professores/Diretores de Escolas: escolha das coleções;

Em S18, o item 10.8 estabelece os responsáveis pelas várias etapas do PNLD 2011. Em 10.8.4, o documento informa a "integral responsabilidade" dos professores e diretores das escolas pela escolha das coleções. Aqui, é importante ressaltar que o texto do Edital diferencia avaliar de escolher, sem oferecer definições formais desses termos. O item anterior ao 10.8.4, portanto, ainda relacionado às responsabilidades, diz:

10.8.3. da Secretaria de Educação Básica/MEC: pré-análise, avaliação pedagógica das coleções e elaboração do Guia de Livros Didáticos;

Ou seja, apesar de os professores e diretores estarem integralmente responsáveis pela escolha das coleções, essa responsabilidade integral não inclui a análise e a avaliação desses materiais. Percebemos, então, que não é previsto que a escolha do professor seja feita a partir de sua própria análise ou avaliação das coleções. Isso porque a responsabilidade pela préanálise e pela avaliação cabe integralmente à Secretaria de Educação Básica (SEB) e ao MEC. O uso do prefixo pré, antecedendo análise, não nos diz muito mais do que afirmar que haverá uma análise anterior à avaliação pedagógica, para a exclusão das coleções que não atendam às disposições gerais. Mesmo porque o termo análise ou analisar não é usado para a etapa em que os professores se envolvem. Uma observação geral é que, no Edital, os verbos usados 
para o termo professor são: escolher, discutir, trabalhar, perceber, buscar, continuar investindo e ampliando; enquanto os verbos analisar e avaliar são usados apenas em conjunto com o prefixo auto quando relacionados à palavra professor. À página 57 do Edital, estão relacionadas ao termo professor apenas as formas: (auto-) observação, (auto-) análise e (auto-) avaliação:

Por sua vez, a aprendizagem na sala de aula é compreendida como construída e reconstruída pelos alunos e professores, como resultado de (auto-)observação, (auto-) análise e (auto-) avaliação.

Observamos que o dizer acima, atravessado por dizeres da abordagem de ensino reflexivo, atribui as funções de analisar e avaliar ao professor somente em relação à sua conduta profissional "na sala de aula" em relação aos seus alunos e a si próprio. Isto é, observar, analisar e avaliar o aluno e, quando da eliminação dos parênteses e da leitura do conteúdo das incisas, se auto-observar, autoanalisar e autoavaliar. Por isso, em se tratando do programa de adoção do livro didático, ao professor cabe apenas escolher as obras dentre as que já foram pré-analisadas, avaliadas e pré-selecionadas pelos órgãos SEB/MEC.

S19

ANEXO X - PRINCÍPIOS E CRITÉRIOS PARA A AVALIAÇÃO DE COLEÇÕES DIDÁTICAS DESTINADAS AOS ANOS FINAIS DO ENSINO FUNDAMENTAL

O PNLD cumpre a função, também, de estimular a discussão e participação de professores na escolha dos materiais didáticos a serem utilizados na escola, contribuindo dessa forma para $\mathrm{o}$ exercício competente de sua profissão.

Vemos, em S19, a possibilidade de leitura sob nossas três categorias de análise e, por isso, analisaremos outros aspectos dos dizeres dessa sequência no próximo capítulo. Por ora, interessa-nos aquilo que o discurso oficial diz sobre a escolha das coleções feita pelo professor. Em S19, referente ao Anexo X, documento específico sobre o modo de avaliação das coleções, a função do professor fica confirmada, mais uma vez, como a de selecionar as coleções já avaliadas. Essa seleção, fruto da discussão e participação dos professores, deve ser estimulada pelo PNLD. Portanto, sem a ação do PNLD, os professores poderão não estar estimulados a discutir e a participar da escolha. É preciso, então, a ação do PNLD para que os professores realizem o "exercício competente de sua profissão". 


\subsubsection{A escolha nos dizeres do Guia de Livros Didáticos}

Os excertos que seguem pertencem ao Guia de Livros Didáticos que, diferentemente do Edital que foi dirigido às editoras, fala diretamente ao professor. Percebemos que o Guia tem o tom mais informal, aproximando-se do professor, enquanto o Edital mantém a distância típica de textos formais e regulatórios. Mesmo assim, os efeitos percebidos não são diferentes; o professor é ainda discursivisado como aquele que fará a escolha das coleções.

S20

\section{Apresentação}

Para decidir qual coleção adotar, converse com seus colegas da mesma área, a fim de que a escolha conjunta reflita os interesses coletivos.

Em S20, o professor é instruído a não fazer a escolha sozinho. A escolha deve, então, refletir os interesses coletivos e não exatamente os interesses do professor individualmente, considerando apenas seus alunos e si próprio. Novamente, vemos que a escolha ("conjunta") está atrelada a vários elementos: às informações das resenhas e, agora, às opiniões de colegas e aos interesses coletivos.

S21

\section{Sobre as coleções selecionadas}

Considerando que esta é a primeira edição do PNLD de LEM, é compreensível que este Guia apresente resenhas de um número reduzido de coleções para sua escolha. Assim mesmo, realize essa escolha de forma criteriosa.

Vemos que, ao longo dos textos oficiais, a escolha que o professor deve fazer fica cada vez mais sob restrições ou condições. Mesmo assim, iniciando com a informação lacunar sobre o número reduzido de opções, nesses dizeres ${ }^{222}$, o PNLD urge o professor a ser criterioso em sua escolha. Antes de prosseguirmos com a análise, vejamos um último dizer sobre a escolha. $\mathrm{O}$ excerto abaixo é apresentado ao final do texto sobre critérios específicos, antes do quadro comparativo no Guia de Livros Didáticos.

S22

Boa escolha e bom trabalho!

\footnotetext{
${ }^{222}$ Analisaremos esses dizeres mais detalhadamente em 5.1.3 adiante.
} 
O que S21, S22, e outros dizeres, parecem desconsiderar é que, como o próprio Guia informa à página 11, dentre as vinte e seis coleções aprovadas na pré-análise, apenas duas foram aprovadas na avaliação pedagógica. Ou seja, a escolha do professor se restringe a duas coleções. Contudo, cada escola já havia sido instruída a escolher exatamente duas coleções, o que simplesmente anula a necessidade de escolha. Anulada essa necessidade, podemos questionar a função de preparação dos professores para a escolha a que se dedica o caderno Língua Estrangeira Moderna do Guia de 2011. No que se refere à Língua Estrangeira Moderna, o Guia funciona, portanto, como um conjunto de dados sobre as coleções selecionadas (resenhas, quadro comparativos, descrições etc.) que informa ao professor sobre as coleções disponíveis para o uso e não exatamente para a escolha.

Uma vez que os dizeres sobre a escolha das coleções de língua inglesa (e também de língua espanhola) no Guia não encontram respaldo numa prática de escolha, esses dizeres exercem uma função apenas retórica, pois não há o que escolher. Mesmo assim, como vimos, os dizeres insistem durante todo o texto do Guia, publicado após a ciência dos órgãos públicos sobre o número de duas coleções aprovadas pela avaliação pedagógica. Sobre isso, devemos atentar aos fatos de que o FNDE divulgou o Guia pela internet em 29 de abril de 2010, o prazo para o registro da escolha foi de 21 de junho a 04 de julho de 2010 e a informação sobre a necessária indicação de duas coleções de língua estrangeira por escola foi feita através da Carta Circular - Orientações para o Registro da Escolha do PNLD 2011 ( $6^{\circ}$ ao $9^{\circ}$ ano), n. ${ }^{o}$ 04/2010, de quatro de abril de 2010, emitida pelo FNDE/MEC. Portanto, a Carta Circular foi divulgada vinte e cinco dias antes do Guia. O texto da Carta Circular ${ }^{223}$ diz:

\section{ESCOLHA}

$[\ldots]$

7.2. Para cada componente curricular, deverão ser escolhidas duas opções $\left(1^{\mathbf{a}}\right.$ e $\left.\mathbf{2}^{\mathbf{a}}\right)$, de editoras diferentes. Preenchida a $1^{\mathrm{a}}$ opção, o responsável só poderá gravar o registro da escolha se a $2^{\mathrm{a}}$ opção estiver preenchida.

Portanto, antes da divulgação do Guia, a Carta Circular já havia informado sobre a necessidade de serem escolhidas duas coleções publicadas por editoras diferentes ${ }^{224}$. Os dizeres do Guia, ao orientarem os professores na escolha das duas únicas coleções que se apresentam analisadas e resenhadas, parecem desconsiderar essa exigência. Ainda que a

\footnotetext{
${ }^{223}$ O texto completo da Carta Circular encontra-se no ANEXO G.

${ }^{224}$ Também no item 5.3 do documento Orientações para o registro da escolha do PNLD 2014 (6 ${ }^{\circ}$ ao $9^{\circ}$ ano), há essa exigência de as coleções pertencerem a diferentes editoras, embora não haja restrições em relação ao pertencimento dessas editoras ao mesmo grupo editorial.
} 
"escolha" feita pelos professores tivesse o objetivo prático de estabelecer qual coleção seria selecionada como primeira opção, os dizeres do próximo item da Carta Circular, de algum modo, garantem a sobrevivência da coleção que ficaria em segundo lugar. Diz a circular:

7.3. Caso não se concretize a aquisição com a editora da $1^{a}$ opção, serão enviados os livros da $2^{\mathbf{a}}$ opção. Por esse motivo, a escolha da $2^{\mathrm{a}}$ opção precisa ser tão cuidadosa quanto à da $\mathbf{1}^{\mathbf{a}}$.

As informações da Carta Circular já seriam suficientes para poupar todo o esforço de elaboração e divulgação do Guia que, por apresentar exatamente dois títulos para a "escolha", torna-se improfícuo dentro do objetivo a que se propõe e passa a assumir o valor de um catálogo informativo, para atender à solicitação de classificação das coleções em primeira e segunda opções. Mesmo assim, os dizeres do Guia seguem sem referência à Carta Circular, nem ao fato de que os dois títulos ali sugeridos devem ambos ser "escolhidos", fazendo crer que uma escolha será realmente realizada. É interessante observar que a necessidade de ambas as coleções serem escolhidas deveria assumir, no Guia, a condição de um já-dito, pois foi informada na Carta Circular. Porém, esse já-dito não é dizível, ou repetível, nos dizeres do Guia sobre a escolha, e acaba funcionando como um não-dito.

Prosseguiremos com a análise, atentando agora não apenas aos dizeres sobre a escolha, mas também aos que possam sustentar a representação do Guia como um documento informativo. Retomando, as informações contidas no Guia de Livros Didáticos instruem os professores a chegarem a um consenso sobre a coleção a ser escolhida. Tais informações concentram-se em três momentos no texto do Guia: na Ficha de Avaliação, no Quadro Comparativo das Coleções de Língua Estrangeira Moderna e nas resenhas respectivas a cada obra. Analisaremos, a seguir, os dizeres reservados a esses momentos.

\subsubsection{A Ficha de Avaliação}

De acordo com o Guia, a Ficha de Avaliação reflete todos os critérios, gerais e específicos que orientaram os avaliadores das coleções. A Ficha contém quatorze itens, desmembrados num total geral de noventa e duas perguntas, que guiaram a avaliação das coleções didáticas para a aprovação final. Não nos propomos analisar todos os itens ou perguntas; apenas nos concentraremos nos dizeres mais relevantes para esta segunda categoria de análise. 
Um dos itens dos Critérios Gerais, o item VI, intitulado Adequação da estrutura editorial e do projeto gráfico aos objetivos didático-pedagógicos da coleção, contém a pergunta vinte e cinco, reproduzida abaixo.

\section{S23}

25. A obra é isenta de erros de revisão e/ou impressão? (Obs.: considerar também as transcrições dos textos dos CDs de áudio.)

De acordo com essa pergunta, os avaliadores das coleções devem verificar se o material (o livro do aluno, o manual do professor e as transcrições do $\mathrm{CD}$, geralmente incluídas em ambos) apresenta erros, como deslizes na forma como o texto foi publicado, erros de ortografia de modo geral. A pergunta é ainda mais enfática; pois, o uso do adjetivo "isenta" iguala o número de erros a zero. Mesmo que tal isenção seja de todo o modo inatingível, na linearidade da pergunta não há tolerância em relação ao número de erros. $\mathrm{O}$ foco de nossa análise, contudo, não se concentra na verificação da existência, na rejeição, nem na aceitação de possíveis "erros". Desejamos, sim, observar o funcionamento discursivo desse dizer sobre a isenção de erros.

Assim, a pergunta não diz que se a resposta for negativa e a obra contiver erros, a coleção estará reprovada. Não há informações sobre as respostas esperadas para as perguntas da Ficha ou sobre a relação entre o tipo de resposta e a avaliação da coleção. Mesmo o título do item VI, Adequação da estrutura editorial e do projeto gráfico aos objetivos didáticopedagógicos da coleção, não invoca a obrigatoriedade de perfeita adequação da estrutura editorial e do projeto gráfico aos objetivos da coleção para que ela seja aprovada.

Portanto, em S23, possivelmente, o dizer aposta no bom senso do avaliador, esperando que ele compreenda que a obra desejada é aquela "isenta de erros de revisão e/ou impressão". Em outros termos, o discurso, aqui, parece funcionar através da concepção construída socialmente de que um livro didático deva ser livre de erros. Assim, a concordância com a pergunta, a resposta afirmativa do avaliador, leva em conta o sentido pré-construído ${ }^{225}$ (PÊCHEUX, M., [1975] 2009, p. 89; HENRY, P., [1975]1990, p. 61) de que a coleção, para ser aprovada, deve ser "isenta de erros". Porém, em momento algum a expectativa em relação às respostas para as perguntas desse item da Ficha é informada. $\mathrm{O}$ que parece ocorrer aqui, e nas demais perguntas da Ficha, é que o discurso oficial, pressupondo a naturalização de um

\footnotetext{
${ }^{225}$ O conceito de pré-construído foi proposto por PAUL HENRY e definido por MICHEL PÊCHEUX ([1975] 2009 , p.89) como algo que "remete a uma construção anterior, exterior, mas sempre independente, em oposição ao que é 'construído' pelo enunciado".
} 
sentido único, se isenta de ter de explicar a implicação entre as respostas às perguntas e a aprovação/reprovação das coleções.

Vejamos outro dizer da Ficha de Avaliação. A sequência S24 transcreve todo o texto referente ao item IV da Ficha, originalmente com apenas dois subitens.

S24

\section{Correção e atualização de conceitos, informações e procedimentos}

1. A obra apresenta, de modo correto, preciso e atualizado, conceitos, informações e procedimentos propostos como objetos de ensino-aprendizagem?

2. A obra utiliza, de modo correto, preciso e atualizado, esses mesmos conceitos e informações, em exercícios, atividades, ilustrações ou imagens?

Agora, temos elementos mais fortes, apontando à naturalização do sentido. Isto é, ao dizermos "a obra apresenta, de modo correto, preciso e atualizado", apelamos ao sentido de ser isso exatamente o que esperamos que tal obra seja. Porém, é importante ressaltar que, apesar de não ser esse o foco de nossa análise, não acreditamos que uma obra, nesse caso, uma coleção didática, possa atingir o grau de perfeição que S23 e S24 defendem; assim como também não acreditamos que a isenção de erros, a correção, a precisão e a atualização são elementos que garantiriam por si só o êxito da coleção didática na sala de aula, apesar de se configurarem como objetivos a serem perseguidos. O que desejamos argumentar é que não é possível saber como uma resposta negativa, por exemplo, repercutiria na avaliação e na aprovação ou reprovação da coleção. Portanto, se houve algum critério para relacionar as respostas à avaliação das coleções, tal critério não é informado ao professor, pois não consta do Guia.

Vemos aí um espaço que abre à multiplicidade ou a uma linha de fuga que, de acordo com Gilles Deleuze ([1990] 2008, p. 212), caracteriza o modo de funcionamento de uma sociedade. Em outros termos, a não explicitação da correspondência entre a resposta positiva ou negativa e a aprovação/reprovação da coleção abre espaço para uma coleção que não corresponda ao pressuposto pela pergunta seja ainda aprovada. Isso porque, ao menos discursivamente, não há como saber, além do que fica pressuposto pela representação préconstruída sobre uma coleção ideal, se há a exigência de que uma coleção cumpra o estabelecido pela pergunta para que seja aprovada.

Além disso, vemos que ambas as perguntas abrangem um vasto número de variantes. Na primeira pergunta, para o modo de apresentação, temos os adjetivos: correto, preciso e atualizado. Partindo desses três adjetivos, podemos ter várias possibilidades de respostas: 
correto, mas impreciso e desatualizado; atualizado, mas incorreto e impreciso etc. A questão fica ainda mais complexa quando consideramos que há três referentes para esses adjetivos: conceitos, informações e procedimentos. Poderíamos, então, ter uma coleção que tivesse conceitos corretos, informações imprecisas e procedimentos desatualizados e, assim, outras tantas variações seriam também possíveis. Apenas não é possível saber os limites do aceitável para a aprovação da coleção: o nível de exigência, nem o grau de tolerância. Esse mesmo efeito pode ser percebido na segunda pergunta, que apenas muda seu foco, procurando garantir a coerência do que é apresentado (primeira pergunta) e o que é praticado na coleção: 1. A obra apresenta... ; 2. A obra utiliza... .

Esse é, assim como entendemos, o funcionamento da sociedade de controle em relação ao adiamento do fim. As noventa e duas perguntas, apesar do número abundante, não garantem o término da avaliação. Ou seja, mesmo que uma coleção não corresponda ao pressuposto pela pergunta, não há como afirmar que o critério que a pergunta encerra seria suficiente para reprovar a coleção.

Como efeito, podemos perceber que a falta de informação sobre a relação entre as respostas esperadas e a aprovação/reprovação da coleção parecer contar não apenas com o bom senso do avaliador, mas também com a naturalização de uma representação de livro didático capaz de não deixar dúvidas ao avaliador e, agora no Guia, também ao professor, sobre o que pode e o que deve o LDI. Ao mesmo tempo, há o efeito de adiamento do fim do processo de avaliação produzido pela mesma falta de relação entre as respostas dos avaliadores e a aprovação/reprovação da coleção.

Em seguida, trataremos dos efeitos produzidos pelo Quadro Comparativo em nossa busca de perceber o controle sobre o funcionamento discursivo do LDI, para que ele circule socialmente como uma verdade.

\subsubsection{O Quadro Comparativo das Coleções de Língua Estrangeira Moderna}

À página vinte do Guia de Livros Didáticos, encontramos o quadro, que reproduzimos mais abaixo, precedido pelos dizeres:

\section{Quadro comparativo das coleções de Língua Estrangeira Moderna}

O seguinte quadro sintetiza o conjunto das coleções aprovadas. A avaliação das coleções de Espanhol e Inglês do PNLD 2011 está representada através da intensidade da cor amarela: quanto mais intensa a cor, mais a coleção atende aos principais critérios especificados no Edital. 

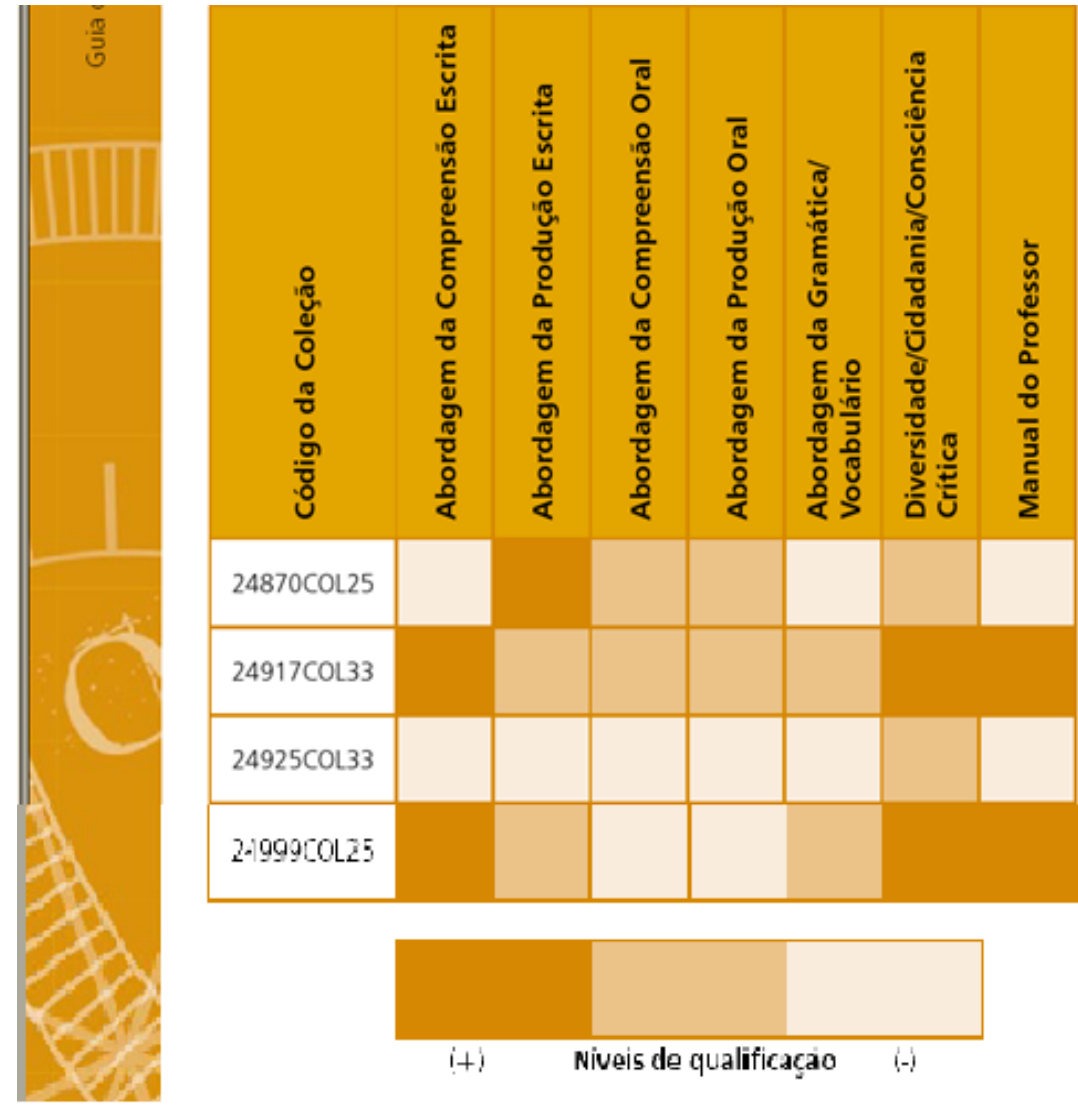

Fig. 5: Quadro Comparativo das Coleções de Língua Estrangeira Moderna - PNLD 2011

De cima para baixo, os códigos das coleções se referem, respectivamente, às coleções de língua espanhola, língua inglesa, língua inglesa e língua espanhola. Portanto, as duas linhas centrais (COL33), que representam as coleções aprovadas para o ensino de língua inglesa, serão consideradas na análise.

Inicialmente, podemos perceber que esse quadro concentra, mais que informações, muitas dúvidas e perguntas sem respostas. Uma questão sem resposta é que as noventa e duas perguntas da Ficha de Avaliação parecem ter sido concentradas nos sete itens do Quadro; porém, não há informações sobre como isso foi feito, nem sobre o tipo de critério usado. De algum modo, as noventa e duas perguntas da Ficha compõem os itens que tradicionalmente marcam para o professor as quatro habilidades da língua, além de um item que separa a gramática e o vocabulário das quatro habilidades, um item dedicado à questão social (diversidade, cidadania e consciência crítica) e um último item reservado ao manual do professor. 
Outro motivo de indagação é o sistema de representação dos níveis de qualificação das obras: o uso de tonalidades de amarelo ${ }^{226}$. Há três opções de tonalidade e não há atribuição de valores às opções, nem tampouco há palavras relacionadas a essas tonalidades que pudessem precisar cada uma delas. Diferentemente da especificidade dos critérios dispostos nas noventa e duas perguntas que guiaram a avaliação das coleções pelos especialistas, aqui, isto é, neste momento em que os dizeres são dirigidos aos professores que farão a escolha das coleções, somos informados na introdução ao Quadro que "quanto mais intensa a cor, mais a coleção atende aos principais critérios especificados no Edital". Podemos supor, então, que a cor mais clara significa que, naquele item, a coleção não atende ou atende muito pouco aos "principais critérios especificados no Edital". Porém, não sabemos quais dos quinze itens e das noventa e duas perguntas, que segundo o Guia refletem todos os Critérios Gerais e os Critérios Específicos, poderiam ser considerados os "principais critérios" nem como eles se alocam nos sete itens elencados no Quadro.

Mais uma vez, retomamos aqui nossa observação sobre a relação entre as respostas das noventa e duas perguntas e a aprovação das coleções. No momento da apresentação das perguntas no Guia, o discurso oficial não esclarece ao professor a relação entre o tipo de resposta esperada e a aprovação ou reprovação da coleção, parecendo ter contado com o bom senso do avaliador. Porém, a graduação de amarelo no Quadro sugere a possibilidade de três tipos de resposta: positiva (tom escuro), negativa (tom claro) e mais ou menos (tom intermediário). A atribuição do tom intermediário aos itens produz o mesmo efeito percebido na translação de "erro" à "falha", isto é, o efeito de suavização da resposta negativa que poderia excluir a coleção da seleção e que, ao mesmo tempo, faz o LDI funcionar como uma verdade. Do mesmo modo, portanto, observamos também aqui a possibilidade de associarmos a modalização do dizer com o modo de funcionamento da sociedade de controle em que a modulação, ao estabelecer possibilidades que não se fecham, se configura como moldes autodeformantes, característicos do funcionamento da sociedade de controle.

É interessante notar que nenhuma das coleções avaliadas recebeu nota máxima em mais da metade dos sete itens avaliados. A segunda coleção de inglês, que aparece como a terceira de cima para baixo no quadro, recebeu apenas uma tonalidade de intensidade média; em todas as demais categorias, essa coleção recebeu a tonalidade mais fraca, ou a avaliação mais baixa. A tonalidade mais intensa (porém de média intensidade) recebida por essa coleção pertence ao item Diversidade, Cidadania, Consciência Crítica, que, apesar de sua grande

\footnotetext{
${ }^{226}$ Já no Guia do PNLD de 2008, que ainda não incluía a disciplina de inglês, as diferentes cores e tonalidades substituem as estrelas que, antes disso, indicavam o tipo de recomendação feita sobre a obra.
} 
relevância aos estudos, não é exatamente um item linguístico. Isto é, esse item poderia/deveria estar presente em coleções para todas as disciplinas e não caracteriza especificamente as coleções para o ensino de língua estrangeira. É surpreendente que essa coleção tenha recebido uma avaliação superior às outras vinte e quatro coleções que não foram aprovadas na avaliação pedagógica.

Como não foi disponibilizada informação alguma sobre as coleções reprovadas, não é possível fazermos quaisquer outros comentários comparativos nem análise, assim como também não é possível aceitar as informações sem questionamentos. Não supomos que a veracidade do Quadro, de modo geral, seria objeto de questionamento. Porém, é interessante observar que as duas coleções aprovadas apresentaram esses resultados; isto é, a primeira apresenta mais tons intermediários do que fortes e a segunda apresenta intensidades fracas de amarelo na grande maioria de itens. Nossa preocupação concerne à representação de ensino de língua inglesa que estamos naturalizando em todo o país.

Sendo esta a primeira vez que o LDI foi adotado em âmbito nacional, é comum atribuir tais resultados ao fato de que as editoras não estavam preparadas ou não tinham experiência nesse segmento. Porém, é preciso dizer que o livro didático de inglês já vinha sendo produzido para a escola pública e até adotado localmente há algum tempo. Além disso, mesmo com a segunda edição do programa incluindo o LDI, o PNLD 2014, que teve vinte e uma coleções avaliadas (cinco a menos do que no PNLD 2011) e três pré-aprovadas (uma a mais do que no PNLD 2011), vemos que o número de quadradinhos com tonalidade máxima é ainda baixo, considerando-se os mesmos critérios do PNLD 2011. Ou seja, no Quadro Comparativo das coleções selecionadas, o PNLD 2014 apresentou nove itens, dois a mais do que o Quadro Comparativo do PNLD 2011. Se tomarmos apenas os itens referentes às quatro habilidades, ou seja, compreensão oral e escrita e produção oral e escrita, presentes em ambos os Quadros, veremos que quase não houve mudanças. 


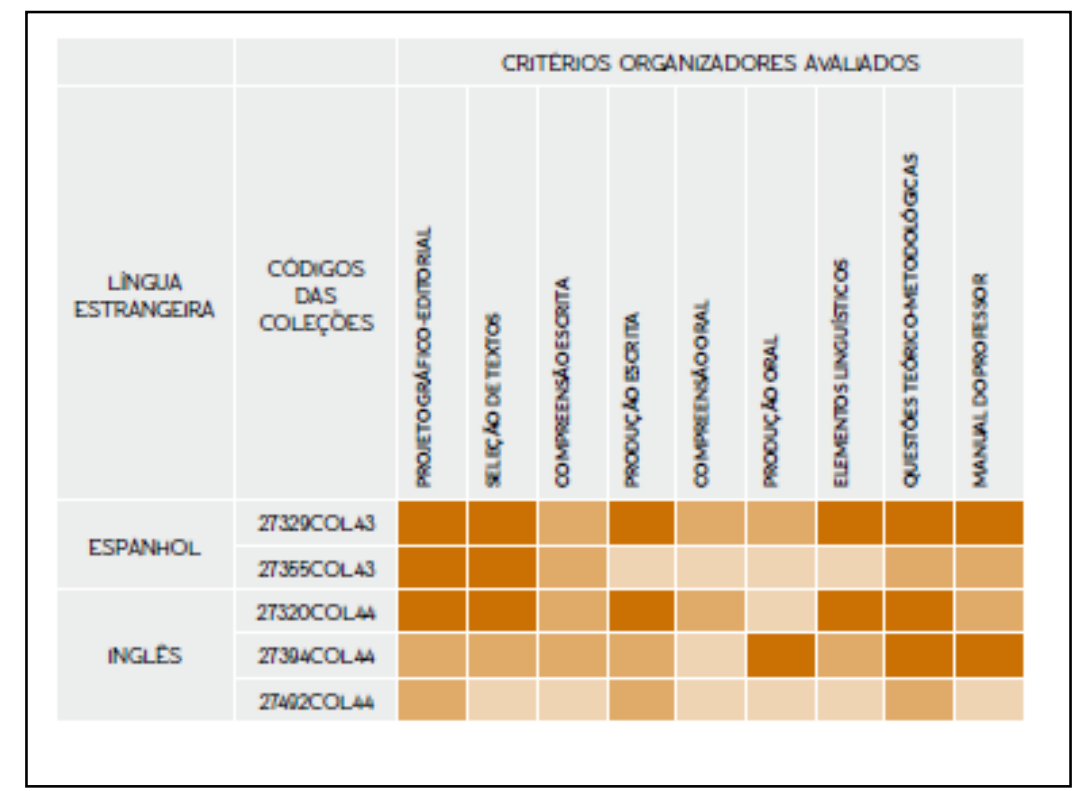

Fig. 6: Quadro Comparativo das Coleções de Língua Estrangeira Moderna - PNLD 2014

Recortando as informações sobre as quatro habilidades nos quadros acima, temos, para ambos os Programas, o seguinte cenário resumido:

\begin{tabular}{|l|l|l|}
\hline \multicolumn{1}{|c|}{ critérios } & \multicolumn{1}{c|}{ PNLD 2011 } & \multicolumn{1}{c|}{ PNLD 2014 } \\
\hline Compreensão oral & 1 média; 1 clara & 1 média; 2 claras \\
\hline Compreensão escrita & 1 intensa; 1 clara & 2 médias; 1 clara \\
\hline Produção oral & 1 média; 1 clara & 1 intensa; 2 claras \\
\hline Produção escrita & 1 média; 1 clara & 1 intensa; 2 médias \\
\hline
\end{tabular}

Fig. 7: Avaliação das quatro habilidades - PNLD 2011 e PNLD 2014

Tomando esses dados como referência e considerando que o PNLD 2014 selecionou uma coleção a mais que o PNLD 2011, vemos que não houve mudança em relação à compreensão oral, a compreensão escrita teve um declínio e as produções oral e escrita melhoraram. Em relação à produção escrita, especificamente, a coleção do PNLD 2011 que recebeu a melhor avaliação (tonalidade média) apresentou como proposta de escrita a elaboração de sentenças nos dois primeiros anos do ensino de inglês, $6^{\circ}$ e $7^{\circ}$ anos, segundo a informação do Guia: "Nos volumes 6 e 7, as atividades limitam-se, basicamente, à produção de sentenças" (GUIA DE LIVROS DIDÁTICOS, PNLD 2011, p. 40). De acordo com a avaliação dos especialistas, a proposta de elaboração de sentenças não foi considerada como produção escrita. Diz o item sobre a produção escrita (GUIA DE LIVROS DIDÁTICOS, PNLD 2011, p. 42), conforme resenham os avaliadores: 
As propostas de produção escrita precisam ser orientadas no sentido de fornecer informações sobre os aspectos linguísticos a serem observados. Nos volumes 6 e 7, o professor deverá complementá-las com as etapas de produção e instruções para reformulação do texto produzido.

Considerando que o termo que grifamos na citação acima tem como referente anafórico as propostas de produção escrita (sujeito gramatical do período anterior), temos que "o professor deverá" complementar "as propostas de produção escrita" "com as etapas de produção". Portanto, nessa coleção do PNLD 2011, não há propostas de produção escrita nos dois primeiros anos do aprendizado de inglês para o aluno da escola pública. Nesse período, a produção escrita restringe-se à elaboração de sentenças.

Como vimos no quadro comparativo das quatro habilidades (Fig. 7), mesmo já contando com a experiência das editoras nesse segmento educacional, as coleções do PNLD 2014 disponibilizadas para a escolha dos professores ainda não apresentam a qualidade que todos esperaríamos encontrar em livros que serão adotados em todo o território nacional pelo período de três anos.

Uma última observação que poderíamos fazer sobre os efeitos de sentido produzidos pelas informações do Quadro Comparativo do PNLD 2011 concerne à "escolha" feita pelo professor. Visualmente, a primeira coleção de inglês (segunda linha no Quadro - PNLD 2011) obteve a melhor avaliação: com três quadradinhos de tonalidade máxima e quatro de tonalidade média, contra um quadradinho de tonalidade média e seis de tonalidade clara atribuídos à segunda coleção de inglês (terceira linha). Se a "escolha" tivesse realmente de ser feita pelo professor e o Quadro fosse usado como parâmetro, não nos parece que a segunda coleção, visualmente menos qualificada (de acordo com os níveis de qualificação do Quadro), seria escolhida. Ou seja, tomando-se o bom senso novamente como pressuposto, o Quadro já determina qual coleção deve ser "escolhida" como primeira opção e qual ocupa o segundo lugar. Apenas como uma observação complementar, dentre os vinte e oito professores que responderam ao segundo questionário, vinte professores adotaram a primeira coleção em suas escolas, três adotaram a segunda coleção, três não adotaram e dois adotaram outras coleções didáticas. 


\subsubsection{As Resenhas}

Embora já tenhamos nos referido aos dizeres das Resenhas no item anterior, deveremos ainda analisá-los em maior profundidade, para complementarmos nossa argumentação sobre a representação do LDI como verdade no discurso oficial.

As resenhas sobre as coleções aprovadas para o PNLD 2011 foram elaboradas pelos especialistas de cada área e compõem a parte final do documento Guia de Livros Didáticos Língua Estrangeira Moderna. Com o objetivo de contribuir com informações sobre as coleções para que os professores fizessem suas escolhas, as resenhas apresentam os mesmos itens para cada uma das coleções de língua estrangeira moderna, espanhol e inglês. São eles: Visão geral, Descrição da coleção, Análise da obra e Em sala de aula. A Análise da obra é composta pelos subitens: Compreensão escrita, Produção escrita, Compreensão oral, Produção oral, Gramática e Vocabulário e, por fim, Manual do professor.

Em momentos anteriores, necessitamos nos referir às resenhas das coleções, pois elas são citadas nos dizeres dos documentos que analisamos. O Edital de Convocação, por exemplo, informa repetidas vezes que a escolha do professor por uma coleção didática deve ser fruto do consenso entre ele e seus colegas e deverá ter como base as resenhas. O texto longo das resenhas, aproximadamente cinquenta por cento do total de páginas do Guia ${ }^{227}$, nos levou a concentrar nossa análise no item intitulado Em sala de aula, mantendo nosso foco em relação às categorias de análise. Esse item difere dos demais por não ter o caráter predominantemente analítico e descritivo presente nos outros itens das resenhas. Em sala de aula é um espaço em que o sujeito enunciador (o sujeito que enuncia a partir da posição de especialista naquela língua e cujo dizer, aqui, compõe ${ }^{228}$ o discurso oficial e é composto por ele) se dirige ao professor para lhe oferecer sugestões práticas e cuidados a serem tomados no uso diário da coleção resenhada.

O primeiro aspecto que nos chamou a atenção em relação ao texto do item Em sala de aula das Resenhas foi o grande número de dizeres repetidos para as quatro coleções aprovadas (inglês e espanhol). Vejamos esses dizeres no quadro abaixo ${ }^{229}$.

\footnotetext{
${ }^{227}$ O Guia de Livros Didáticos - Língua Estrangeira Moderna tem um total de quarenta e três páginas; o texto correspondente ao item Resenhas ocupa vinte páginas desse documento.

${ }^{228}$ Cf. o conceito de função-autor como a função discursiva do sujeito que, segundo FOUCAULT, M. ([1969] 2002, p. 53), é responsável pela unidade, coerência e origem do discurso.

${ }^{229}$ Os textos integrais dos itens Em sala de aula de ambas as coleções encontram-se nos ANEXOS H e I.
} 


\begin{tabular}{|c|c|c|}
\hline \multirow{4}{*}{ 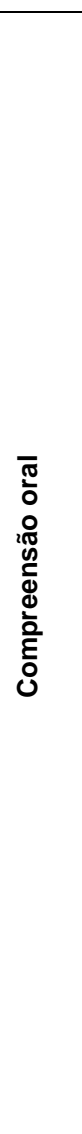 } & $\begin{array}{l}1^{\text {a }} \text { coleção } \\
\text { de inglês }\end{array}$ & $\begin{array}{l}\text { Em relação à compreensão oral, o aluno deve ser levado a observar a } \\
\text { forma como os textos refletem as intenções, os objetivos comunicativos, } \\
\text { os estados de ânimo e as atitudes dos interlocutores, bem como as } \\
\text { consequências de variações dessa natureza para a comunicação. Um dos } \\
\text { procedimentos que pode favorecer esse trabalho é o de pausar o CD para } \\
\text { possibilitar reflexão, projeção, levantamento e checagem de hipótese. }\end{array}$ \\
\hline & $\begin{array}{l}2^{\mathrm{a}} \text { coleção } \\
\text { de inglês }\end{array}$ & $\begin{array}{l}\text { No trabalho com a compreensão oral, cabe ao professor a tarefa de levar o } \\
\text { aluno a observar a forma como os textos refletem as intenções, os } \\
\text { objetivos comunicativos, os estados de ânimo e as atitudes dos } \\
\text { interlocutores, bem como as consequências de variações dessa natureza } \\
\text { para a comunicação. Um procedimento que pode favorecer esse trabalho } \\
\text { é o de pausar o CD para possibilitar reflexão, projeção, levantamento e } \\
\text { checagem de hipótese. }\end{array}$ \\
\hline & $\begin{array}{l}1^{\text {a }} \text { coleção } \\
\text { de espanhol }\end{array}$ & $\begin{array}{l}\text { Com relação à compreensão oral, é importante que se leve o aluno a } \\
\text { observar a forma como os textos refletem as intenções, os objetivos } \\
\text { comunicativos, os estados de ânimo e as atitudes dos interlocutores, bem } \\
\text { como as consequências } \\
\text { de variações dessa natureza para a comunicação. Isso pode ser feito } \\
\text { através de pausas no texto oral para reflexão, projeção, levantamento e } \\
\text { checagem de hipótese. }\end{array}$ \\
\hline & $\begin{array}{l}2^{\mathrm{a}} \text { coleção } \\
\text { de espanhol }\end{array}$ & $\begin{array}{l}\text { As propostas de compreensão oral precisam incluir atividades que } \\
\text { promovam a reflexão sobre as intenções, os objetivos comunicativos, os } \\
\text { estados de ânimo } \\
\text { e as atitudes dos interlocutores, bem como as consequências de variações } \\
\text { dessa natureza para a comunicação. Isso pode ser feito mediante o uso de } \\
\text { pausas no texto oral para reflexão, projeção, levantamento e checagem de } \\
\text { hipótese. }\end{array}$ \\
\hline \multirow{4}{*}{ 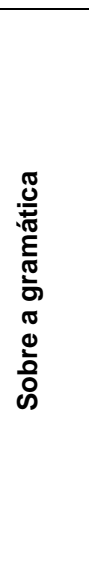 } & $\begin{array}{l}1^{a^{2}} \text { coleção } \\
\text { de inglês }\end{array}$ & $\begin{array}{l}\text { o trabalho com a gramática, é conveniente conduzir os alunos a um } \\
\text { studo mais reflexivo da língua. }\end{array}$ \\
\hline & $\begin{array}{l}2^{\mathrm{a}} \text { coleção } \\
\text { de inglês }\end{array}$ & $\begin{array}{l}\text { Convém dar ao trabalho com a gramática um caráter mais articulado com } \\
\text { o uso da língua através das quatro habilidades. }\end{array}$ \\
\hline & $\begin{array}{l}1^{\text {a }} \text { coleção } \\
\text { de espanhol }\end{array}$ & $\begin{array}{l}\text { Convém dar ao trabalho de análise e reflexão sobre a gramática um } \\
\text { caráter mais articulado com o uso da língua através das quatro } \\
\text { habilidades. }\end{array}$ \\
\hline & $\begin{array}{l}2^{\mathrm{a}} \text { coleção } \\
\text { de espanhol }\end{array}$ & $\begin{array}{l}\text { No trabalho com a gramática, nos volumes } 6 \text { e } 7 \text {, é importante que o } \\
\text { professor conduza os alunos a um estudo mais reflexivo, de modo a } \\
\text { possibilitar-lhes a ampliação da capacidade de uso da língua nas diversas } \\
\text { situações sociais. }\end{array}$ \\
\hline \multirow{4}{*}{ 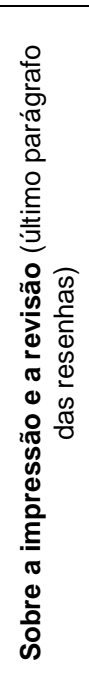 } & $\begin{array}{l}1^{\mathrm{a}} \text { coleção } \\
\text { de inglês }\end{array}$ & $\begin{array}{l}\text { Não foram encontrados erros significativos na obra. No entanto, na sua } \\
\text { utilização em sala de aula, o professor precisará estar atento para corrigir } \\
\text { algumas falhas de impressão e revisão no Livro do Aluno e no Manual do } \\
\text { Professor. }\end{array}$ \\
\hline & $\begin{array}{l}2^{\mathrm{a}} \text { coleção } \\
\text { de inglês }\end{array}$ & $\begin{array}{l}\text { Não foram encontrados erros significativos na obra. No entanto, na sua } \\
\text { utilização em sala de aula, o professor precisará estar atento para corrigir } \\
\text { algumas falhas de impressão e revisão no Livro do Aluno e no Manual do } \\
\text { Professor. }\end{array}$ \\
\hline & $\begin{array}{l}1^{\text {a }} \text { coleção } \\
\text { de espanhol }\end{array}$ & $\begin{array}{l}\text { Não foram encontrados erros significativos na obra. No entanto, na sua } \\
\text { utilização em sala de aula, o professor precisará estar atento para corrigir } \\
\text { algumas falhas de impressão e revisão no Livro do Aluno e no Manual do } \\
\text { Professor. }\end{array}$ \\
\hline & $\begin{array}{l}2^{\mathrm{a}} \text { coleção } \\
\text { de espanhol }\end{array}$ & $\begin{array}{l}\text { Não foram encontrados erros significativos na obra. No entanto, na sua } \\
\text { utilização em sala de aula, o professor precisará estar atento para corrigir } \\
\text { algumas falhas de impressão e revisão no Livro do Aluno e no Manual do } \\
\text { Professor. }\end{array}$ \\
\hline
\end{tabular}

Fig. 8: Quadro de dizeres repetidos nas Resenhas 
A repetição dos dizeres nos textos muito $\operatorname{curtos}^{230}$ desse subitem Em sala de aula nos convocou à análise. Em especial, a análise das representações de professor e de aluno nos pareceu ter mais relevo nos dizeres repetidos. Isso porque, parece-nos, que a repetição desses dizeres, com poucas variações, não ocorre apenas no uso das estruturas e do léxico. Vemos que, em cada repetição, os mesmos traços identitários de professor, aluno e livro didático se reafirmam. Destacamos, abaixo, parte dos dizeres sobre o item Compreensão Oral.

S26 - o aluno deve ser levado a observar

S27 - cabe ao professor a tarefa de levar o aluno a observar

S28 - é importante que se leve o aluno a observar

S29 - As propostas de compreensão oral precisam incluir atividades que promovam a reflexão

Mesmo que nas sequências discursivas S26 e S28 desconheça-se o sujeito gramatical que fará a ação de levar, sabemos, pelo efeito de pré-construído (PÊCHEUX, M., [1975] 2009, p. 89; HENRY, P., [1975]1990, p. 61), que é o professor que se encarrega da "tarefa de levar o aluno a observar", como é explicitado em S27. Desse modo, tanto o aluno como o professor são representados com traços identitários historicamente construídos que remetem a enunciados que caracterizam o professor como condutor e sujeito do saber e o aluno como conduzido e aquele que nada sabe. Em outros termos, os dizeres produzem o efeito de que, se o professor não conduzir o aluno à observação, ele nada observará.

Por outro lado, na sequência discursiva S29, esse trabalho de promover a observação, a reflexão, fica atribuído às atividades que devem complementar o livro didático. Observamos, nesse dizer, alguns apagamentos: quem incluirá as atividades nas propostas e quem irá refletir? Novamente, portanto, esse dizer conta com saberes pré-construídos que já determinam aqueles que devem, numa situação de aula, elaborar atividades e aqueles que devem refletir a partir dessas atividades. Porém, observamos que esses apagamentos dirigem o foco do dizer sobre o livro didático. Isto é, se as propostas de compreensão oral precisam incluir atividades, é porque essas atividades não são oferecidas nas propostas. Mesmo sutilmente, esse dizer aponta a falhas e à incompletude do livro didático ao mesmo tempo em que mantém o professor e o aluno distantes por apagamento. A partir da percepção desses efeitos em S29, podemos observar que as sequências anteriores, ao enfocarem o aluno e o professor, parecem trabalhar no sentido de poupar o livro didático da falha e da incompletude.

\footnotetext{
${ }^{230}$ No documento oficial, os textos Em sala de aula das resenhas de espanhol têm trinta linhas cada; para as coleções de inglês, a primeira resenha tem dezessete linhas e a segunda tem vinte e sete.
} 
Também nos dizeres do item Sobre a gramática, podemos perceber os mesmos efeitos e as mesmas representações de professor, aluno e livro didático. Enquanto os dizeres referentes à primeira coleção de inglês oculta o sujeito gramatical do verbo conduzir, em "conduzir os alunos", os dizeres da segunda coleção de espanhol explicita que "professor conduza os alunos". Ambos os dizeres remetem às mesmas representações de aluno e professor analisadas acima. Do mesmo modo, os dizeres referentes à segunda coleção de inglês e à primeira de espanhol atribuem a falha ao livro didático, neste caso, a falta de articulação entre a gramática e o uso da língua. E, ainda, atribuem ao professor a incumbência de promover essa articulação "através das quatro habilidades", mantendo-o na posição de uma pessoa que age $e^{231}$.

A relevância dessas observações pode ser sentida na necessidade de compreendermos o modo de funcionamento do discurso oficial, em especial, na dispersão dos enunciados. Como dissemos no item 5.1.2.1, a Ficha de Avaliação apresenta, segundo o Guia de Livros Didáticos, todos os critérios que orientaram a avaliação das coleções. Em 5.1.2.1, analisamos a pergunta vinte e cinco e, agora, retornamos a ela, com outro foco. No dizer analisado em S23, a pergunta 25 sobre a isenção de erros localiza-se à página 15 do Guia:

25. A obra é isenta de erros de revisão e/ou impressão? (Obs.: considerar também as transcrições dos textos dos CDs de áudio).

Já o excerto abaixo pertence ao texto das resenhas e aparece à página 42 , referente à primeira coleção de inglês, e à página 48 , referente à segunda coleção de inglês. Como vimos no Quadro de dizeres repetidos nas Resenhas (Fig. 8), esse texto é reescrito palavra por palavra nas resenhas de todas as obras aprovadas.

Não foram encontrados erros significativos na obra. No entanto, na sua utilização em sala de aula, o professor precisará estar atento para corrigir algumas falhas de impressão e revisão no Livro do Aluno e no Manual do Professor.

É interessante notar que o termo "erros" aparece adjetivado como "significativos" no texto das resenhas, enquanto no texto da pergunta 25 da Ficha de Avaliação, constante do Guia, o termo "erros" é apenas qualificado de acordo com o tipo: "de revisão e/ou impressão". Ou seja, a pergunta que guiou os avaliadores não distinguiu erros significativos de

\footnotetext{
${ }^{231}$ A representação de professor como uma pessoa que age (Cf. FOUCAULT, M., 1982, p. 220) é discutida no sexto capítulo.
} 
insignificantes. Portanto, na pergunta, a falta de informação sobre a aceitação de algum grau de significância do erro acaba por generalizar sua severidade. Entende-se, então, que nenhum tipo de erro, significativo ou não, será aceito.

De todo o modo, a resenha não diz que as coleções são isentas de erros, simplesmente admite que não foram encontrados erros significativos. Outros erros, portanto, podem ter sido encontrados. Mas, esses outros erros encontrados, os não tão significativos ao ponto de desclassificar as duas coleções, não são denominados de "erros" agora. O termo "erros", usado na pergunta 25 da Ficha, foi substituído por "falhas" no texto das resenhas que, portanto, estabelece a diferença, a não sinonímia, entre erros e falhas.

Ainda contrariando a inadmissão de erros informada na pergunta 25 da Ficha, temos um processo que poderíamos chamar de metonimização amenizante, um deslize de erros para erros significativos e também de erros para falhas. Admitindo essa diferença estabelecida no/pelo dizer, podemos supor que a palavra "erros" produza o sentido de ser algo grave, enquanto "falhas" seriam amenas, temporárias, inconsequentes e/ou um tipo de erro de fácil reajuste. Vemos, então, que essa metonimização amenizante funciona no discurso como uma modalização do dizer. Entendemos que a modalização produz um efeito que corrobora o modo de funcionamento da sociedade de controle. Isto é, a modalização do dizer produz a abertura a múltiplas possibilidades que não se estabilizam nem se fixam. Ao contrário, funcionam na sua flexibilidade e instabilidade, como uma "moldagem auto-deformante" (DELEUZE, G., [1990] 2008), tomando o lugar dos moldes rígidos da sociedade disciplinar que age por imperativos e garantindo, também, as linhas de fuga.

Contudo, essa amenização do termo "erros" para "falhas" é esperada devido à mudança de certos elementos das condições de produção do discurso estabelecidas nas diferentes partes do Guia. Ou seja, a palavra "erros", sem a informação sobre qualquer grau de severidade que pudesse apresentar, foi produzida discursivamente no momento do Guia em que havia condições favoráveis ao seu uso: entre as noventa e duas perguntas que estabeleciam, com o rigor do discurso oficial, os critérios específicos para a aprovação das coleções pelos especialistas. A palavra "falhas", por sua vez, foi produzida num lugar desse mesmo documento onde a modalização pode e deve apoiar discursivamente o dizer que aprova a coleção apesar de conter "erros". Ou seja, a palavra "falhas", como a modalização do termo "erros", substitui ou torna desnecessária a explicação sobre a aceitação dos "erros" e sobre a consequente aprovação das coleções. Podemos considerar, também, que a palavra "erros" é produzida por um sujeito enunciador diferente daquele que produz a palavra 
"falhas" 232 . O primeiro corresponde ao sujeito enunciador das perguntas que guiaram a avaliação dos especialistas; o segundo, ao sujeito especialista. Nessa consideração, é possível perceber que a modalização de "erros" para "falhas" contribui à construção de linhas de fuga. Isto é, o dizer do sujeito especialista não se compromete com a isenção de erros exigida pelo sujeito enunciador das perguntas; ao contrário, ele denuncia a presença de "falhas" no mesmo lugar em que "erros" são proibidos.

Como efeito, mesmo que as coleções aprovadas apresentem essas "falhas", elas são discursivisadas como verdades e, portanto, estão aptas a serem "escolhidas" pelos professores. Isto é, apesar de conterem "falhas", as coleções não contêm "erros" e são, portanto, verdades. Esses erros insignificantes ou "falhas" ficam, ainda, sob a responsabilidade do professor; pois, é o professor que "precisará estar atento para corrigir algumas falhas de impressão e revisão no Livro do Aluno e no Manual do Professor”. Observamos, então, a representação do LDI como um saber e o professor como aquele que irá garantir o funcionamento desse saber em sala de aula.

Em relação à modalização, notamos que muitos dos dizeres que compõem o quadro acima (Fig. 8) recorrem repetidamente aos termos: “convém”, “é conveniente”, “é importante", "pode favorecer" etc. Vemos que esses termos tanto defendem um posicionamento a ser adotado pelo professor (é conveniente = é aconselhável) quanto abrem a linhas de fuga (é conveniente $=$ não é obrigatório/ posso fazê-lo/ não preciso fazê-lo etc.). Assim, mesmo com a ênfase na defesa do que se está aconselhando (aquilo que convém, é importante, conveniente ou favorece), o sentido do dizer não se fixa e remete a possibilidades contrárias ou divergentes ao aconselhamento. Parece-nos, então, que a modalização provoca, na materialidade linguística, um jogo intradiscursivo que encontra, no interdiscurso, mais de uma possibilidade de sentido.

Ainda com o objetivo de percebermos a modalização como um efeito que corrobora o modo de funcionamento da sociedade de controle, passaremos, a seguir, à análise de dizeres de três momentos do discurso oficial.

\subsubsection{A escolha na sociedade de controle}

Como vimos anteriormente, o primeiro livro para o ensino de inglês no Brasil parece ter sido o Grammatica pratica da Lingua Ingleza de Fillipe Maria da Motta d'Azevedo Corrêa, impresso em 1890 na França por Guillard, Aillaud \& Cia e comercializado no Brasil

\footnotetext{
${ }^{232}$ Agradecemos à $\operatorname{Prof}^{\mathrm{a}}{ }^{\mathrm{a}} \mathrm{Dr}^{\mathrm{a}}{ }^{\mathrm{a}}$ Maralice de Souza Neves pela observação que nos fez atentar a essa diferença.
} 
pela Livraria Clássica de Alves, Rio de Janeiro ${ }^{233}$. Interessa-nos sobre essa obra, "adoptada no Imperial Collegio de Pedro II, Instituto Commercial e nos principaes estabelecimentos, litterarios do Imperio"234, a informação de que ela, antes de ser adotada e utilizada em aula com os alunos, tenha sido "approvada pelo Conselho Director d'Instrucção publica" ${ }^{235}$. Ou seja, o primeiro livro didático de inglês já havia sido pré-selecionado e submetido à aprovação de um órgão oficial. Isso não foi alterado com a promulgação da primeira constituição republicana no ano seguinte, em que o Estado assume, "de forma definitiva, as rédeas da educação, instituindo várias escolas públicas de ensino fundamental e intermediário"236.

Aquilo que ficará, daí em diante, alterado será a formulação dos dizeres sobre a aprovação dos títulos a serem adotados. Isto é, os dizeres sobre o primeiro livro de inglês adotado no Brasil que citamos acima ("adoptada no Imperial Collegio de Pedro II, Instituto Commercial e nos principaes estabelecimentos, litterarios do Imperio" e "approvada pelo Conselho Director d'Instrucção publica") estão impressos nas páginas do próprio livro e trazem em si as marcas discursivas do poder soberano que age por imperativos, sem a necessidade de informar os detalhes envolvidos no processo de adoção. Ou seja, não há informação de que tenha ocorrido alguma seleção que pudesse ter, por sua vez, levado à escolha desse livro. Seja pela falta de detalhamento de informações (quando, onde, como, por que e sob quais circunstâncias e critérios essa obra foi aprovada para a adoção), seja pelo próprio uso da voz passiva, os dizeres se produzem no discurso como a enunciação que basta, que é suficiente, num regime que se quer ainda soberano. Não cabe, numa sociedade de soberania, colocar em questão a justificativa, mesmo lacunar, do soberano.

No ano de 1945, foi emitido o Decreto-lei cujo item cinco analisamos abaixo. Nessa época, vigorava a Reforma Capanema que, como vimos anteriormente, definiu e implantou leis, estabelecendo programas e diretrizes. É nesse cenário, brevemente descrito neste estudo ao tratarmos da Reforma Capanema, que o Decreto-lei n. 8.460 de 26 de dezembro de 1945 consolida a legislação sobre as condições de produção, importação e de utilização do livro didático no país. Destacamos, para análise, o artigo cinco desse decreto ${ }^{237}$, que confere ao professor a escolha dos livros que deverão ser adotados. Diz o artigo:

${ }^{233}$ Segundo o banco de dados LIVRES da Faculdade de Educação da USP. Disponível em: 〈http://paje.fe.usp.br/estrutura/livres/>. Acesso em: 15 jun. 2011.

234 Idem

235 Idem.

${ }^{236}$ Cf. 〈http://pt.wikipedia.org/wiki/Constitui\%C3\%A7\%C3\%A3o brasileira_de_1891>. Acesso em: 28 jan. 2013.

237 Disponível em: 〈http://www.jusbrasil.com.br/diarios/2617701/dou-secao-1-28-12-1945-pg-8/pdfView〉. Acesso em: 15 mar. 2011. 
S31

Os poderes públicos não poderão determinar a obrigatoriedade de adoção de um só livro ou de certos e determinados livros para cada grau ou ramo de ensino nem estabelecer preferência entre os livros didáticos de uso autorizado, sendo livre aos professores de ensino primário, secundário, normal e profissional a escolha de livros para uso dos alunos, uma vez que constem da relação oficial das obras de uso autorizado. Parágrafo único. A direção das escolas primárias, normais, profissionais e secundárias, sejam públicas ou particulares, não poderá, relativamente ao ensino dêsses estabelecimentos, praticar os atos vedados no presente artigo.

Nessa sequência discursiva, observamos que os elementos que contribuem ao efeito de argumentação nesses dizeres, já sem o tom imperioso dos meios soberanos, se colocam como estratégias de organização através da disciplina, daquilo que se pode ou não fazer: "os poderes públicos não poderão"; "a direção das escolas [...] não poderá”. A argumentação discursiva 238 sobre a escolha do livro didático, então, se dá através do estabelecimento da ordem, da disciplina, daquilo que pode ser feito e daquilo que é proibido.

Mesmo esse estabelecimento do proibido e do permitido não deixa de opacificar os detalhes e critérios que derivaram a "relação oficial das obras de uso autorizado". Vemos que, agora em 1945, a escolha do livro didático é atribuída ao professor, ou melhor, é dita como sendo uma ação que o professor deverá realizar. Mas, mesmo sendo "livre aos professores de ensino primário, secundário, normal e profissional a escolha de livros para uso dos alunos", a escolha deve ainda obedecer a uma exigência: o livro deve ser escolhido dentre aqueles que "constem da relação oficial das obras de uso autorizado". Portanto, os poderes públicos devem respeitar a liberdade de escolha do professor desde que o professor escolha os livros que já foram selecionados e listados pelos poderes públicos para que sejam escolhidos. Em outros termos, a escolha já está, até certo ponto e discursivamente, determinada; pois, os poderes públicos só não podem determinar qual livro o professor irá escolher dentre aqueles já autorizados. Desse modo, fica garantido o controle governamental sobre os livros que circularão no país.

Destacamos, a seguir, os quatro únicos momentos do Guia em que o termo "escolha" se refere à escolha do livro didático de inglês pelo professor. O primeiro excerto encontra-se no final do primeiro item do Guia, denominado Apresentação. Esse item marca o endereçamento direto do documento aos professores logo em seu início, com a introdução: "Prezado Professor, Prezada Professora". O último parágrafo da apresentação lê:

\footnotetext{
${ }^{238}$ Referimo-nos à argumentação como um funcionamento discursivo percebido como efeito produzido pelo discurso de um sujeito cindido, atravessado pela ideologia, pela história, pela língua e pelo inconsciente; portanto, o termo "argumentação" não se refere, neste estudo, à intenção de um sujeito centrado em persuadir o outro com seu discurso.
} 
S32

Recomenda-se a leitura cuidadosa deste Guia e das resenhas nele contidas, pois, como já dito, cada resenha apresenta uma coleção, faz uma breve descrição e análise do conteúdo de cada um de seus volumes, além de apontar as qualidades em destaque na coleção e os cuidados necessários no seu uso. Dessa forma, você terá condições de avaliar e decidir qual é a coleção mais adequada para seus alunos, para você e para sua escola. Para decidir qual coleção adotar, converse com seus colegas da mesma área, a fim de que a escolha conjunta reflita os interesses coletivos.

Em S32, acima, vemos que a escolha que se objetiva é conjunta ("converse com seus colegas da mesma área") e resultante de um processo que sugere a "leitura cuidadosa" do Guia e das resenhas produzidas por especialistas (professores avaliadores das obras). Nas resenhas, os especialistas descrevem, analisam os conteúdos e apontam "as qualidades em destaque na coleção", além dos "cuidados necessários" no uso das coleções. Apenas após a "leitura cuidadosa" do Guia e das resenhas, o professor "terá condições de avaliar e decidir qual é a coleção mais adequada para seus alunos [...]”. Isto é, o saber profissional e a capacitação técnica do professor não são reconhecidos como requisitos suficientes para fazer a escolha, que deverá, ainda, ser discutida com os colegas para que, assim, não sejam refletidos apenas os interesses do professor, mas de toda a coletividade a que pertence. Salientamos, ainda, que a leitura e análise das coleções propriamente ditas não é mencionada aqui, nem em outros momentos do Guia, como necessária para que o professor faça sua escolha.

Ainda nesse excerto, vemos que os elementos argumentativos funcionam no discurso de modo bem diferente daqueles que analisamos em S31 e nos dizeres inscritos no livro Grammatica pratica da Lingua Ingleza. Lembramos que, em relação ao seu apoio na materialidade linguística, a $\operatorname{argumentação~}^{239}$ das inscrições no livro de 1890 funcionava através da voz passiva, deixando as marcas do poder soberano; em S31, a argumentação se apoiava no modo imperativo do verbo poder, organizando, proibindo e disciplinando as ações. Agora, em S32, notamos a suavização dos elementos argumentativos através do efeito de modalização percebido no verbo que inicia o parágrafo: "Recomenda-se", acrescido de articuladores discursivos como "pois", "Dessa forma", "além de", "a fim de que" que apresentam uma série de razões e justificativas que fortalecem a "recomendação". Porém, apesar desse fortalecimento, uma recomendação é ainda uma sugestão que poderá ser ou não aceita. Vemos aí os elementos discursivo-argumentativos marcando a materialidade linguística e produzindo efeitos de sentido que nos remetem ao funcionamento das moldagens

\footnotetext{
${ }^{239}$ Cf. nota anterior.
} 
autodeformantes, os princípios moduladores da sociedade de controle, em que há sempre um adiamento do término. Isto é, o professor que fará a escolha não é instruído para simplesmente ler as coleções, tomar sua decisão e escolher a coleção que mais lhe pareça adequada aos seus fins. Ao contrário, ele é levado por um longo processo em que, a cada passo, a escolha é adiada, pois depende de sua "leitura cuidadosa" das cinquenta e duas páginas do Guia, das resenhas constantes no Guia, de sua aceitação de todas as justificativas e apontamentos dos especialistas sobre as coleções, de sua conversa com os colegas até chegar a uma escolha que não seja só sua, mas que "reflita os interesses coletivos". Marcando, ainda, o adiamento do fim desse processo, os dizeres do Guia garantem que tudo isso é apenas uma recomendação, que poderá ou não ser seguida.

Vejamos o próximo excerto, com duas ocorrências do termo "escolha".

\section{S33}

Considerando que esta é a primeira edição do PNLD de LEM $^{240}$, é compreensível que este Guia apresente resenhas de um número reduzido de coleções para sua escolha. Assim mesmo, realize essa escolha de forma criteriosa. Esperamos, por fim, que os resultados desta avaliação contribuam para uma aprendizagem efetiva e significativa de línguas nas escolas públicas brasileiras.

A primeira ocorrência do substantivo "escolha" aparece ao final da justificativa para o "número reduzido de coleções": "esta é a primeira edição". A justificativa apela à compreensão do professor: "é compreensível”. A argumentação, portanto, funciona com a apresentação de uma justificativa seguida de um apelo. Nesse dizer, o apelo não é dirigido diretamente ao professor; ao contrário, ao mesmo tempo em que mantém o distanciamento (é compreensível $=$ todos compreendem), convoca o professor a ocupar o lugar junto àqueles que compreendem: se é compreensível, você, professor, deverá também compreender. Contudo, aquilo que fica apagado nesse momento do dizer é a justificativa do número reduzido de coleções selecionadas para comporem as opções de coleções. Iniciando e introduzindo o item sob o título de Sobre as coleções selecionadas, temos a única referência a essa justificativa informada no parágrafo anterior a S33:

No PNLD 2011, 37 coleções participaram do processo de avaliação pedagógica, sendo 11 de espanhol e 26 de inglês. Das coleções avaliadas, foram aprovadas duas de cada uma das línguas. As demais coleções foram

\footnotetext{
${ }^{240}$ Língua Estrangeira Moderna.
} 
excluídas por não cumprirem os critérios do Edital, o que, em alguns casos, poderia inviabilizar seu uso em sala de aula. (BRASIL, MEC/PNLD, 2011)

Contrastando com as informações precisas sobre os números das coleções participantes, a informação que explicaria o número reduzido de coleções aprovadas é vaga e geral, pois espera-se que as coleções aprovadas cumpram os critérios e que as reprovadas não o façam, assim como em qualquer processo seletivo. A redundância dessa justificativa emerge no discurso como um indício, que passamos a analisar.

É interessante notar a presença de outro elemento argumentativo que parece também funcionar, na materialidade linguística, como uma suavização; isto é, uma modalização, semelhante às moldagens deformáveis da pós-modernidade, para lembrar Deleuze mais uma vez. Referimo-nos a "em alguns casos", que ocorre na última frase dessa citação que destacamos acima. Ou seja, de acordo com esses dizeres, se "em alguns casos" as coleções excluídas poderiam "inviabilizar seu uso em sala de aula", em outros casos, isso não ocorreria; as coleções reprovadas seriam ainda viáveis. Esse uso da modalização não chega a caracterizar, como vemos, uma contradição. O que ocorre é o oferecimento de outras possibilidades, com o adiamento do fim, da conclusão. Isto é, assim como a recomendação da "leitura cuidadosa", que analisamos acima, poderá ou não ser seguida pelo professor, também as coleções reprovadas inviabilizariam seu uso em sala de aula somente "em alguns casos".

Esses dizeres que não se estabilizam oferecem mais de uma possibilidade de ação, como uma rota alternativa, ou ainda uma linha de fuga (DELEUZE, G., ([1990] 2008, p. 212). Parece-nos, então, que os dizeres marcados pelas modalizações produzem o efeito de linhas de fuga, garantindo o lugar para o surgimento de outras possibilidades e adiando a estabilização e o término, como as modulações que demandam intermináveis atualizações. Vemos aí o modo de funcionamento do poder na sociedade de controle. Isto é, ao mesmo tempo em que outras possibilidades são garantidas pelo funcionamento do poder que apresenta discursivamente linhas de fuga, o dizer trabalha para proteger e assegurar o sentido que deseja manter: o professor deve fazer a "leitura cuidadosa", "as demais coleções foram excluídas".

Antes de finalizarmos nossas observações neste item, gostaríamos de registrar a palavra ao professor que já utiliza o livro didático do PNLD 2011, para que possamos perceber algumas reações desses professores sobre a "escolha" que fizeram. Esses dizeres pertencem ao segundo questionário de pesquisa. 
P16Q2

O elenco de livros a serem adotados já é previamente determinado por uma equipe e isso faz com que os professores não tenham, efetivamente, uma autonomia na escolha do material de apoio de suas aulas. Há uma predileção por livros de mesmo perfil "amadeumarquesiano", dentre outros autores, que seguem uma linha de apresentação de enunciados em língua materna (língua portuguesa) e desenvolvimento de atividades em língua-alvo (língua inglesa), o que não reforça o vínculo com a prática deste idioma. A prática da língua-meta fica, portanto, bastante circunscrita. Não defendo o hermetismo de estudo das línguas, mas quero dizer que o processo de leitura e compreensão dos enunciados na língua-alvo faz parte de um trabalho que traz, sem dúvida alguma, resultados bastante satisfatórios.

P13Q2

Pontos a ser melhorados: precisamos de mais opções de livros, e muitas vezes os livros escolhidos não são os que vêm para a unidade. Eu me considero sortuda, pois o livro que escolhi foi o que chegou, mas meus demais colegas de outras unidades escolares não receberam suas primeiras opções.

P17Q2

O acesso ao material é positivo, mas a escolha dos livros deveria ser mais criteriosa no que se refere ao trabalho que se propõe desenvolver em sala. Os alunos recebem os livros, mas é inviável utilizá-los na prática.

P7Q2

Nem no ensino fundamental nem no ensino médio, eu recebi todas as coleções para analisar em tempo hábil. Na primeira escolha do LD eu só recebi o keep in mind, logo só podia escolher ele. Na escolha do ensino médio, recebi mais coleções, no entanto, se tivesse recebido todas, teria escolhido outra, que só recebi depois da escolha oficial.

P11Q2

O professor deveria ter mais opções de escolha pois, muitas vezes, é ofertada apenas uma única opção e é freqüente a não presença do professor nessa escolha, pois a gestão da escola que faz esse papel.

Não vamos, neste momento, analisar detalhadamente as declarações dos professores que, aqui, contribuem na formação de um quadro que nos permite observar a posição que o professor ocupou no processo de escolha. P16Q2 afirma que a pré-determinação dos títulos a serem adotados retira do professor o próprio direito de escolher o material com o qual trabalhará em seu dia a dia com os alunos. P13Q2 pede por mais opções de títulos e respeito pela "escolha" que fez: "muitas vezes os livros escolhidos não são os que vêm para a unidade". É preciso dizer que o suprimento do livro que o professor considerou sua primeira opção não deveria depender de "sorte"; pois, afirma P13Q2: "Eu me considero sortuda, pois o livro que escolhi foi o que chegou". P8Q2 nega a viabilidade de usar os livros com seus alunos, questionando os critérios, ou a falta deles, na escolha do livro recebido e aponta à incompatibilidade, portanto, entre o livro e a aula. Para que P7Q2, P11Q2 e demais 
professores pudessem opinar e discutir sobre os livros que estavam sendo adotados para o PNLD 2011, precisariam ter recebido as duas coleções selecionadas "a fim de que a escolha conjunta" refletisse "os interesses coletivos", nas palavras do Guia, como vimos. No entanto, P7Q2 e P11Q2 afirmam ter recebido apenas uma das coleções para o segmento correspondente aos anos finais do Ensino Fundamental. Assim, e mesmo tendo que escolher ambas, P7Q2 não chegou a conhecer a outra coleção. Por sua vez, P11Q2 parece afirmar não ter participado diretamente da escolha, afirmando que essa tarefa é realizada pelo gestor: "a gestão da escola que faz esse papel”.

Portanto, consideramos que os dizeres desses professores, que já utilizam o livro didático de inglês do PNLD 2011, protestam contra a posição passiva que tiveram de ocupar durante o processo de escolha. Além disso, parece-nos que a questão da viabilidade de uso do material na prática do ensino deve realmente ficar a cargo do professor. Afinal, é ele quem conhece seus alunos, sua comunidade. Vemos, então, que além do controle sobre quais livros podem circular na sociedade através do oferecimento de uma relação de títulos de coleções adotáveis, há ainda elementos contingentes relacionados à realidade de cada escola, de cada professor, que (de)limitam ainda mais a ação do professor de escolher o livro com o qual trabalhará.

Mesmo após a primeira adoção nacional do LDI, o controle sobre os livros que podem circular nas escolas brasileiras continua ainda sendo realizado pelo mesmo oferecimento de uma relação de títulos pré-aprovados aos professores. No PNLD 2011, trinta e sete coleções participaram do processo de avaliação pedagógica: onze coleções de espanhol e vinte e seis de inglês, dentre as quais duas coleções foram aprovadas para cada uma das línguas. O PNLD 2012, que inaugurou a distribuição de livros de língua estrangeira para o Ensino Médio, teve trinta e duas coleções de língua estrangeira inscritas; dentre elas, vinte eram de inglês. Sete coleções de inglês foram aprovadas. O PNLD 2014, que corresponde à renovação do PNLD 2011, teve trinta e seis coleções inscritas, sendo vinte e uma de inglês. Três coleções de inglês foram aprovadas. Resumimos essas informações no quadro abaixo.

\begin{tabular}{|c|c|c|c|}
\cline { 2 - 4 } \multicolumn{1}{c|}{} & PNLD 2011 & PNLD 2012 & PNLD 2014 \\
\hline Segmento & $6^{\circ}$ ao $9^{\circ}$ ano E.F. & E.M. & $6^{\circ}$ ao $9^{\circ}$ ano E.F. \\
\hline Coleções inscritas (inglês) & 26 & 20 & 21 \\
\hline Coleções aprovadas (inglês) & 2 & 7 & 3 \\
\hline
\end{tabular}

Fig. 9: Número de coleções inscritas e aprovadas nos Programas 
O Edital do PNLD 2014 definiu duas composições para as coleções de língua estrangeira moderna: Tipo 1, com material impresso e CD de áudio; Tipo 2, com material impresso e DVD. Foram inscritas cinco coleções de inglês Tipo 1 e dezesseis coleções Tipo 2. É interessante observar que nenhuma das coleções com DVD, portanto Tipo 2, foram aprovadas. Apesar de o Guia informar já no item Apresentação: "Conforme previsto no item 3.1.3 do edital, a 'não aprovação da totalidade dos conteúdos multimídia de uma coleção do Tipo 2 não será fator de exclusão da coleção impressa'", nenhuma coleção Tipo 2 foi aprovada. Sobre isso, no item As coleções selecionadas, o próprio Guia informa rapidamente: "No processo de avaliação, não foram aprovados os DVDs das coleções de Tipo 2".

Como o acesso às informações sobre as coleções reprovadas não é público, não é possível determinar o motivo desse resultado desastroso; pois, das dezesseis coleções com DVDs, nenhuma foi aprovada e, das cinco coleções com CDs, três foram aprovadas. Em uma videoconferência ${ }^{241}$ disponibilizada pela Rede do Saber da Secretaria de Estado da Educação, Silvia Nogueira, professora e responsável pela equipe curricular de Língua Estrangeira Moderna dessa Secretaria, afirma ter participado de um seminário sobre o PNLD 2014, quando conheceu os critérios de avaliação das coleções didáticas. Naquela ocasião, Nogueira foi informada que o motivo da reprovação de todas as coleções do PNLD Tipo 2 concentra-se principalmente nos tipos de conteúdos apresentados que traziam atividades que poderiam ser feitas no livro em papel e não se caracterizavam como conteúdos digitais. $\mathrm{Na}$ videoconferência, Nogueira lamenta: "as editoras não conseguiram apresentar material de qualidade".

De todo o modo, o que o professor tem à sua frente é uma relação de coleções aprovadas pelo PNLD, para que ele faça sua escolha. Essa escolha, porém, está imbricada em complexos procedimentais, formais ou contingentes, em que a ação do professor de escolher fica sempre sendo adiada. Mesmo que o professor utilize o livro que escolheu dentre aqueles que constem na relação, uma nova escolha já está prevista ao final de três anos, como vimos em 2.3.

Analisamos, aqui, os dizeres de dois momentos do discurso oficial sobre a escolha do livro didático pelo professor da escola de ensino regular brasileira, tendo ainda, como apoio, os dizeres inscritos no primeiro livro de inglês utilizado no Brasil. Cada um desses momentos nos ajuda a observar os modos de funcionamento da argumentação no discurso de três épocas: o período ainda marcado pela sociedade de soberania, com os inscritos no livro Grammatica

$241 \quad$ Disponível em: $<$ http://www.rededosaber.sp.gov.br/portais/Videoteca/tabid/179/language/ptBR/Default.aspx >. Acesso em: 19 ago. 2013. 
pratica da Lingua Ingleza de 1890; o período da sociedade disciplinar da Segunda Guerra Mundial, com o Decreto-lei n. 8.460 de 1945; e o período pós-Segunda Guerra, que instala lentamente a sociedade de controle, segundo Deleuze ([1990] 2008, p. 219-20), com os excertos do Guia de Livros Didáticos do PNLD de 2011.

$\mathrm{Na}$ materialidade linguística dos dizeres, pudemos observar os elementos argumentativos que, ao mesmo tempo, caracterizam e se adéquam aos funcionamentos das sociedades em cada época. Nas sociedades de soberania, prevalecia a decisão do soberano, com o discurso em tom performativo e sem detalhamento ou justificativas; nas sociedades disciplinares, a argumentação se marcava pelo uso de comandos e imperativos, para garantir a ordem, o controle e inculcar a disciplina; nas sociedades de controle, percebemos que os elementos que contribuem à produção discursiva da argumentação funcionam pela modalização, para assegurar o adiamento do término, através de processos contínuos e intermináveis, e para garantir caminhos alternativos e linhas de fuga.

Por outro lado, a análise discursiva nos permitiu observar, para além de mudanças no funcionamento argumentativo dos dizeres recortados de três épocas, que a escolha dos materiais didáticos jamais esteve nas mãos dos professores que os utilizam.

\subsection{Dizeres do discurso profissional}

Para esta segunda categoria de análise, em que buscamos perceber a representação de LDI como verdade, observaremos inicialmente as respostas dos professores à segunda e à terceira perguntas do primeiro questionário de pesquisa. Respectivamente, as perguntas feitas foram:

2) Que tipo de material você utiliza atualmente? Há quanto tempo você utiliza esse material?

3) Como a utilização do livro didático afetaria seu dia a dia?

P6Q1 responde à segunda pergunta com os dizeres abaixo.

\section{S34 - P6Q1}

Há cerca de 10 anos utilizo vários materiais em minhas aulas: revistas, jornais, vídeos, músicas, internet, panfletos, anúncios, paradidáticos, encartes de supermercado, dicionários, gibis, charges, etc. Dos mesmos uso uma boa variedade de textos de diferentes gêneros: embalagens, propagandas, anúncios, fichas pessoais, HQ, pirâmides alimentares, etc. Preparo minhas aulas, tiro minhas xerox e as uso em sala de aula.

A resposta de $\mathrm{P} 6 \mathrm{Q} 1$ para a terceira pergunta do questionário vem a seguir. 
S35 - P6Q1

Afetará muito pouco, pois como eu disse será apenas mais um recurso. Tudo dependerá do livro, do seu conteúdo. Se houver material autêntico de boa qualidade vou verificar como usar em minhas aulas.

Vemos que P6Q1 assume uma posição que indica certa autonomia em relação à escolha, coleta e utilização dos materiais didáticos. Mais que autonomia, podemos dizer que há alguns elementos nos dizeres de P6Q1 que produzem o efeito de que esse sujeito não apenas está satisfeito com os materiais que utiliza, mas também se orgulha da variedade de materiais e até do modo como os coleta, utiliza e, enfim, os controla. Num primeiro momento, vemos que P6Q1 nomeia nada menos que doze materiais, para exemplificar a variedade que utiliza. Em seguida, P6Q1 lista também os sete gêneros textuais com os quais trabalha. O acréscimo da palavra "etc." ao final sugere que P6Q1 considera as listas ainda incompletas, indicando que haveria outros exemplos a serem incluídos. Percebemos que há ênfase na noção de variedade, pois P6Q1 diz: "utilizo vários materiais" e "uso uma boa variedade de textos de diferentes gêneros". A variedade de materiais e gêneros parece produzir, para P6Q1, um sentimento de completude que lhe rende autonomia, controle e satisfação. Vemos isso culminar na última frase do excerto, em que P6Q1 diz enfaticamente: "minhas aulas" (que aparece novamente na resposta à terceira pergunta) e "minhas xerox". Para esse sujeito, o LDI do PNLD 2011 "será apenas mais um recurso", ou mais um item na sua lista de materiais. P6Q1 se coloca, então, numa posição de controle sobre os materiais que seleciona, prepara, distribui e utiliza, atuando, portanto, no processo de ensino.

O que nos chama a atenção nos dizeres de P6Q1 é que esse sujeito atribui valor de verdade aos materiais conhecidos como materiais autênticos. Para Coracini (1999, p. 18), o "material chamado autêntico" teve sua inserção no ensino de língua inglesa através das "propostas alternativas", a partir do advento da abordagem comunicativa da Linguística Aplicada, que "defendem a escolha de materiais diferenciados". Tais materiais recebem essa classificação por terem como alvo leitores nativos, isto é, autóctones, que não sejam aprendizes de inglês como língua estrangeira ${ }^{242}$. Os dicionários, especialmente os monolíngues, são muitas vezes classificados como materiais autênticos, pois considera-se que sejam consultados tanto por leitores nativos quanto por aprendizes da língua. Assim, com

\footnotetext{
${ }^{242}$ CORACINI, M. J. (1999, p.34) utiliza aspas no termo "autêntico" ao considerar que esse tipo de material é aquele "produzido para fins de comunicação entre os falantes de uma dada língua e não para fins didáticos". Também TOMLINSON, B. (2011) define materiais autênticos como aqueles produzidos para comunicar e não para lecionar. No entanto, ele acrescenta que esses materiais não precisam ser produzidos por falantes nativos daquela língua e podem ser versões simplificadas de um material original.
} 
exceção de "paradidáticos", todos os demais materiais citados nos dizeres são materiais autênticos. Apesar disso, os paradidáticos geralmente utilizados na disciplina de língua inglesa são adaptações de obras famosas de escritores ingleses ou americanos conhecidos. Com muitas perdas lamentáveis, essas adaptações procuram proporcionar aos alunos o acesso às obras originais, tidas como "verdadeiras", utilizando na escrita um conjunto de itens lexicais e de tempos gramaticais considerados adequados aos níveis de aprendizado supostos dentro de uma linearidade imaginária e tradicional no ensino de inglês como língua estrangeira. Há, portanto, o sentido naturalizado de que o paradidático de inglês é a obra "verdadeira" de tal autor que foi "apenas" adaptada ao nível dos alunos. Assim, o paradidático ocupa, no ensino de inglês, o status de material "quase" autêntico.

Ser autêntico parece ser o critério de P6Q1 para escolher os materiais que utiliza, pois essa é também a condição imposta por P6Q1 para o LDI. Ou seja, P6Q1 espera encontrar no LDI algum tipo de "material autêntico de boa qualidade", com que possa trabalhar. Mesmo assim, e ainda mantendo-se no controle, P6Q1 irá "verificar" como esses materiais autênticos do LDI serão usados em suas aulas.

Em seus dizeres, P6Q1 não representa o LDI do PNLD, nem outro único LDI, como um material ideal. A exigência de P6Q1 por uma grande variedade de materiais autênticos nos leva a perceber que, nos dizeres desse sujeito, o LDI ideal seria aquele que se configurasse como uma compilação de materiais autênticos; pois, assim, traria apenas a verdade em suas páginas. Como para P6Q1 a verdade está nos materiais autênticos, podemos dizer que para esse sujeito a verdade existe, é possível de ser encontrada em algum lugar e é aquilo que de ve compor o LDI ideal. P6Q1 ainda não encontrou o LDI ideal (pois, há dez anos utiliza vários materiais) e não acredita que o LDI do PNLD seja esse ideal que ele busca (pois, "será apenas mais um recurso"). P6Q1 parece, então, conviver com essa impossibilidade de completude, com a falta constitutiva; isto é, com a impossibilidade de encontrar o ideal.

Portanto, nos dizeres de P6Q1, o LDI, não aquele do PNLD nem outro qualquer, mas o LDI ideal é representado como verdade. Em outros termos, a representação do LDI como um lugar de verdade habita o imaginário de P6Q1. Essa concepção de LDI discursivisada por P6Q1 tem grande relevância à nossa pesquisa. Isto é, podemos compreender que a representação do livro didático de inglês no discurso que fala sobre ele não trata de um LDI específico, nem mesmo do LDI do PNLD 2011, visto que este não era ainda conhecido pelos professores. Trata, no entanto, de um LDI ideal que deve materializar a verdade que há de reger o ensino de inglês como língua estrangeira no Brasil. Assim, podemos afirmar que, 
nesses dizeres do discurso profissional sobre o LDI, o livro didático de inglês é representado como sendo a verdade.

Às mesmas perguntas, P7Q1 responde:

S36 - P7Q1

Caderno do aluno distribuído pela Secr. de Educação; posters; jogos; vídeos; textos. Alguns como textos, jogos e vídeos há muito tempo. O caderno do aluno é utilizado há 2 anos.

S37 - P7Q1

Facilitaria o Trabalho desde que fosse utilizado o mesmo livro para todas as escolas, para facilitar também a vida do aluno, quando necessita mudar de escola, uma vez que consegue acompanhar a sequência didática da mesma série onde for estudar. As vezes não sabemos o que ensinar pois cada professor usa material diferente um do outro.

Para P7Q1, o LDI do PNLD 2011 parece vir com o objetivo de estabelecer uma sequência didática para cada ano escolar. Uma vez estabelecida, de acordo com P7Q1, essa sequência facilitará a vida do aluno que se transferir de uma escola à outra. A sequência que será estabelecida no/pelo LDI auxiliará também ao professor; pois, como afirma P7Q1, o uso de materiais diferentes por cada professor acaba confundindo os outros professores sobre o que exatamente devem ensinar. Portanto, podemos afirmar que, nesses dizeres de P7Q1, o LDI é discursivisado como uma verdade: aquela que virá estabelecer a sequência que todos devem seguir, que não mais confundirá os professores e, ainda, que fará o professor saber o que ensinar. Isso porque, como lemos na última frase de S37, sem o LDI, na condição de elemento homogeneizante do ensino, o professor não sabe o que ensinar. O LDI do PNLD 2011 é, então, representado como um saber, uma verdade, que direcionará o professor, informando o que o professor deve ensinar.

Ao atribuir grande importância à questão da sequência de conteúdos, como o fator determinado pelo LDI, esse sujeito parece não reconhecer tal sequência nas apostilas do Caderno do Aluno do Projeto São Paulo Faz Escola. Ou seja, mesmo que as apostilas sejam já usadas há dois anos no estado de São Paulo, o LDI ainda facilitará o "Trabalho", com maiúscula, por oferecer uma sequência de conteúdos cuja existência nas apostilas não é reconhecida por P7Q1 e que só e será estabelecida no/pelo LDI.

É interessante observar, ainda, que P7Q1, ao falar sobre as apostilas e, também, ao referir-se ao tempo em que nem mesmo elas existiam ("há muito tempo"), cita uma lista de 
materiais que complementam seu trabalho: jogos, pôsteres, vídeos e textos. Pelo longo tempo que P7Q1 insiste na utilização desses materiais listados, parece-nos que eles não são percebidos pelo sujeito como materiais que trariam também conteúdos e que poderiam diferir de professor para professor, como fazem as apostilas, causando a confusão que P7Q1 menciona sobre o que ensinar. A complementação oferecida por esses materiais, contudo, não é mencionada na sequência discursiva que trata do LDI. Como efeito, percebemos que o LDI, para P7Q1, não necessita desses materiais para complementá-lo. O LDI do PNLD 2011 parece, então, ser representado como completo; um saber completo que virá fazer com que o professor saiba o que ensinar.

Também em resposta às perguntas dois e três do primeiro questionário, P8Q1 responde:

S38 - P8Q1

Utilizo vários livros didáticos, de vários autores e editoras diferentes - +/- 8 livros diferentes. Utilizo como base $\mathrm{p} /$ montar exercícios escritos e orais, transcrevo algumas partes para fins de cópias no mimeógrafo, "monto" joguinhos. Utilizo CDs/ fitas cassete/ etc. Há $+/-\underline{\underline{8}}$ anos.

S39 - P8Q1

Enriqueceria o universo vocabular do alunado e facilitaria a preparação das aulas pelos professores.

Vemos que P8Q1 destacou alguns elementos em seu texto possivelmente pelo desejo de chamar nossa atenção para aquilo que ele considera importante. Primeiramente, P8Q1 sublinha a palavra "base". Com isso, percebemos que esse sujeito deseja enfatizar que não se utiliza dos oito livros, num número aproximado, diretamente extraindo deles atividades para suas aulas. Ao contrário, ele os usa "como base" para criar suas atividades. Isto é, P8Q1 parece enfatizar seu trabalho de adaptação que, partindo de todos esses livros, culmina em exercícios que têm ainda sua marca pessoal. Apesar de a palavra "montar" não aparecer em destaque, uma segunda ocorrência desse verbo aparece entre aspas logo abaixo. Temos então: montar exercícios escritos e orais e, também, "monto" joguinhos. Somando-se a essa ênfase gerada pelos grifos sobre seu trabalho de adaptação das atividades, vemos que os verbos que aparecem no dizer relacionam-se ao trabalho físico, manual: utilizo (que inicia três das quatro sentenças em S38), montar, transcrevo e monto. Com o dizer "para fins de cópias no mimeógrafo", esse efeito de ênfase no trabalho físico se acentua. Para essa tarefa, é preciso 
copiar o texto, forçando a caneta contra o estêncil para que as marcas de carbono se fixem bem à matriz. Depois disso, é preciso umedecer a bandeja com álcool, prender a matriz ao cilindro da máquina e rodar a manivela com firmeza para cada uma das cópias desejadas. Essa rotina já dura, para P8Q1, há oito anos. O número aproximado de oito anos, duplamente sublinhado, produz o efeito de uma duração que o sujeito julga como sendo excessiva, além do que se desejaria ou esperaria.

Além dessa representação do trabalho do professor como sendo predominantemente físico, como vimos acima, há também elementos que apontam à desatualização: mimeógrafo e fitas cassete. Esses itens estão, há muito tempo, ultrapassados e obsoletos. Porém, para $\mathrm{P} 8 \mathrm{Q} 1^{243}$, eles fazem parte da sua rotina há aproximadamente oito anos. Uma rotina que poderia ser alterada com a chegada do LDI do PNLD 2011; pois, em sua resposta à terceira pergunta, P8Q1 considera que a utilização do LDI "facilitaria a preparação" de suas aulas.

Em relação ao aluno, apesar de todo o trabalho de P8Q1 na busca e elaboração de atividades, é interessante observar que esse sujeito acredita, ainda, que o LDI tem muito mais a oferecer. Ao referir-se à contribuição do LDI para o aluno, notamos que os termos nos dizeres de P8Q1 produzem efeitos que acabam por representar o LDI como sendo superior ao material que ele produz. Isto é, o LDI não apenas ampliaria o conhecimento lexical dos alunos; ele "enriqueceria o universo vocabular do alunado". Portanto, parece-nos bastante razoável afirmar que, nesses dizeres de P8Q1, o LDI do PNLD 2011 é representado como um saber, uma verdade que virá aliviar o professor de seu trabalho físico, árduo e ultrapassado, superando os resultados desse trabalho em quantidade ("universo") e qualidade (“enriqueceria").

Passamos, agora, às respostas dos professores ao segundo questionário. Para observarmos se e como o LDI do PNLD 2011 é representado como uma verdade, um saber, analisamos os dizeres das respostas à terceira pergunta do segundo questionário.

3. Caso você utilize alguma das coleções adotadas, você está satisfeito(a)? Explique os motivos.

Em resposta a essa pergunta, $\mathrm{P} 5 \mathrm{Q} 2$ respondeu:

\footnotetext{
${ }^{243}$ Como esclarecimento sobre as condições de produção do discurso desse sujeito, informamos que P8Q1 leciona em uma escola situada na cidade de São Paulo, SP.
} 
$\mathrm{S} 40-\mathrm{P} 5 \mathrm{Q} 2$

Não estou satisfeita. O livro adotado pela escola até que bom, mas não contempla o alinhamento curricular na íntegra. E assim não podemos mergulhar nele e explorá-lo da maneira que ele possa contribuir de fato.

Vemos que a insatisfação de P5Q2 resulta da incompatibilidade entre o livro adotado e o livro ideal no imaginário desse sujeito. Isto é, P5Q2 parece definir o LDI ideal como aquele que "contempla o alinhamento curricular na íntegra" e como, para P5Q2, o livro adotado não o faz, ele o reprova. Contudo, essa reprovação é parcial, pois, apesar da força da assertiva negativa iniciando a sentença, P5Q2 afirma que o livro adotado "até que [é] bom". Mesmo assim, a vontade de P5Q2 seria "mergulhar" no LDI, "explorá-lo"; ou seja, usá-lo em sua plenitude. Para P5Q2, portanto, apenas o uso pleno do LDI justificaria sua real contribuição e o deixaria satisfeito. Mas como o livro não está totalmente alinhado aos conteúdos curriculares, isso não acontece. Portanto, há, para P5Q2, um LDI ideal. Um LDI que se deixasse explorar, ser mergulhado e que, contemplando o alinhamento curricular, contribuísse "de fato", satisfazendo o professor. Em outros termos, P5Q2 crê no LDI como um saber completo, uma verdade integral, mas não considera que o LDI do PNLD 2011 seja esse livro ideal.

Outro sujeito responde à mesma pergunta:

S41 - P6Q2

Estou satisfeita com o livro adotado, embora eu não me prenda somente no livro. Os textos não são grandes e ótimos para trabalhar a pronúncia e tradução.

Ao contrário de P5Q2, P6Q2 está satisfeito com o livro adotado. Dentre as atividades do LDI, P6Q2 destaca os textos, avaliando-os como ótimos para as tarefas que propõe aos seus alunos. Além de usar o LDI do PNLD 2011, podemos entender que P6Q2 utiliza outros materiais, pois informa que ele não se prende apenas ao livro. No entanto, não é possível saber quais outros materiais $\mathrm{P} 6 \mathrm{Q} 2$ utiliza, como esses materiais são incorporados às aulas, nem o motivo que o leva a fazê-lo. Como esse sujeito não menciona quaisquer prejuízos em relação ao planejamento das aulas devido ao uso de outros materiais, é possível supor que P6Q2 realize algumas substituições ou subtrações de atividades, para manter-se dentro do planejamento escolar. De todo o modo, apesar de P6Q2 declarar-se satisfeito com o livro, não nos parece que ele considere o livro adotado como completo, pois se utiliza de outros recursos. Esses recursos parecem, então, contribuir para que a aula de P6Q2 atinja o grau de 
completude que ele imagina ser ideal. Porém, mesmo sendo representado como incompleto, o LDI ainda o satisfaz. Isso talvez ocorra porque P6Q2 encontre, nas lacunas do LDI, espaço para inserções de outros materiais. A aprovação de P6Q2 corrobora a representação de LDI como um saber que, mesmo incompleto, funciona como uma verdade.

Ao contrário dos dois respondentes ao segundo questionário cujos dizeres analisamos acima, P7Q2 está apenas parcialmente satisfeito. Vejamos o dizer abaixo.

\section{S42 - P7Q2}

Estou parcialmente satisfeita com a coleção. Nos anos finais, devido ao longo período que os alunos tiveram aulas de PURA gramática, eles sentiram muitas dificuldades em usar o livro devido a sua proposta de um ensino mais sociointeracional. No entanto, os alunos dos anos iniciais, não tiveram problemas com o livro, fizeram todos os exercícios e foi possível usar o $\mathrm{CD}$, e arriscar algumas aulas de listening e speaking, que até então, não tinha ministrado na escola pública. Essa parte do livro, listening e speaking, nos anos finais não foi utilizada, porque os alunos, simplesmente, não topavam. Alguns alunos me questionavam se não tinha gramática, apesar de ter alguns exercícios no livro. Trabalhar com textos foi especialmente difícil porque os alunos não tinham nenhum conhecimento de estratégias de leitura.

Pela narrativa de P7Q2, vemos que sua satisfação parcial deve-se aos resultados do uso do LDI com seus alunos. Enquanto os alunos iniciantes realizaram as atividades propostas pelo livro com sucesso, os alunos dos últimos anos tiveram "muitas dificuldades". P7Q2 atribui a diferença desses resultados ao conhecimento prévio do aluno. Por um lado, os alunos que já tinham estudado inglês em séries anteriores estavam acostumados com um método mais tradicional, isto é, voltado à gramática e sem trabalho específico em relação à oralidade e às estratégias de leitura. Um método que P7Q2 descreve como sendo composto de "PURA gramática". Vemos que, ao usar maiúsculas, P7Q2 se posiciona em relação ao antigo método, reprovando-o e, de certo modo, responsabilizando-o por não poder trabalhar com textos, com os exercícios de compreensão e produção oral e até pela rejeição dos alunos em relação ao trabalho com a oralidade, pois, "os alunos, simplesmente, não topavam". Por outro lado, os alunos iniciantes não apresentaram dificuldades e realizaram as atividades a seu contento. Em outros termos, os alunos iniciantes "não tiveram problemas com o livro" justamente por serem iniciantes. Como eles não haviam trabalhado com o método de "PURA gramática", não rejeitaram o trabalho com a oralidade: "foi possível usar o $\mathrm{CD}$, e arriscar algumas aulas de listening e speaking".

Para P7Q2, trabalhar a oralidade na escola pública foi também uma novidade: "que até então, não tinha ministrado na escola pública". Vemos que o trabalho com a oralidade não era, para P7Q2, estranho; apenas não havia ministrado "aulas de listening e speaking” com os 
alunos da rede pública de ensino. Porém, agora, que a oralidade compõe o LDI, P7Q2 deve ministrar essas aulas e não consegue fazê-lo com os alunos não iniciantes. Com os alunos iniciantes, que não estudaram a "PURA gramática" é possível "arriscar algumas aulas de listening e speaking", mas não com os demais.

Se, como afirma P7Q2, as partes referentes às atividades de compreensão e produção oral não foram utilizadas nos anos finais, aquilo que foi utilizado do livro corresponde essencialmente à compreensão e produção escrita; ou seja, as mesmas habilidades trabalhadas nos métodos tradicionais. Sendo assim, percebemos que, para P7Q2, o LDI pode ser trabalhado com os alunos iniciantes; mas, com os demais, apenas parte dele pode ser trabalhada e, ainda, com certa dificuldade ("Trabalhar com textos foi especialmente difícil").

Desse modo, percebemos que o LDI do PNLD 2011 é representado como um saber nos dizeres de P7Q2, mas como um saber que, de algum modo, para esses alunos, não consegue suplantar uma verdade anterior já estabelecida. Por isso, os alunos iniciantes, que não conheciam outra verdade, o aceitaram e "não tiveram problemas". Porém, para os alunos dos anos finais, o saber do LDI não conseguiu superar o saber construído pela "PURA gramática”. Vemos com certo estranhamento essa rejeição da oralidade da língua pelos alunos de $7^{\circ}$ ao $9^{\circ}$ ano. Os alunos adolescentes nessa faixa etária apreciam músicas e filmes e, por isso, são atraídos pela oralidade e costumam rejeitar a gramática. Uma possível resposta a esse nosso estranhamento poderia ter de considerar que esses alunos percebam o inglês muito mais como uma disciplina escolar, que se baseia em regras para erros e acertos, do que como uma língua. Nesse sentido de ser uma disciplina escolar, o inglês tem sua gramática, direcionando um percurso possível entre o certo e o errado; mais acessível, mais calculável.

Na condição de língua estrangeira, o inglês, como qualquer outra língua, pode mostrar na falta e nas falhas da gramática aquilo que uma disciplina escolar não consegue discernir como sendo erro ou acerto. Por outro lado, a oralidade da língua expõe o falante à crítica aberta a todos, enquanto o erro gramatical é visível apenas para poucos. O aluno pode escolher a quem, além do professor, mostrará seu exercício resolvido, mas não pode controlar totalmente quem o ouvirá arriscar na língua estrangeira. Essa questão de que tratamos é bastante preocupante entre os adolescentes que procuram a aprovação social e temem o julgamento de seus colegas. Seria preciso observar cuidadosamente o modo como constituímos e implementamos novos saberes, novas verdades; pois, não podemos de todo evitar que nossas melhores inovações possam se tornar algo temível para muitos adolescentes brasileiros. 
Ainda para percebermos a representação de LDI e de aluno nos dizeres dos professores que já utilizam o LDI do PNLD 2011, destacamos os dizeres de P1Q2, também em resposta à terceira pergunta.

S43 - P1Q2

Sim, o CD room ajuda muito nas aulas. O livro é de fácil entendimento. O próprio aluno consegue resolver algumas atividades.

Vemos que a representação de aluno historicamente construída como aquele que nada sabe volta a se constituir nesses dizeres de P1Q2. De início, a ênfase marcada pela palavra "próprio" antes de aluno produz o efeito de surpresa nos dizeres de P1Q2, como se não fosse esperado que o aluno pudesse realizar as atividades sozinho. Ainda nessa mesma frase, vemos o trabalho da modalização, abrindo a possibilidades. Isto é, para P1Q2, o aluno não resolve as atividades; ele "consegue resolver". A diferença que observamos entre resolve e "consegue resolver" é que, no primeiro caso, a resolução é simples e rápida: frente à atividade, o aluno a resolve. Já no segundo caso, a resolução das atividades é representada como algo mais difícil; um processo que demanda esforço e tempo: o aluno consegue resolver. A ação do aluno frente às atividades fica então estendida, adiada até que ele consiga resolvê-las. Em relação às atividades, a modalização funciona pela restrição das atividades que o aluno consegue resolver ("algumas") e abre para a possibilidade de existirem atividades que não podem ser resolvidas. Desse modo, o dizer "o próprio aluno" acaba funcionando como uma denegação, pois há atividades que ele não consegue resolver sozinho, mesmo que o livro seja "de fácil entendimento". Em outros termos, a diferença entre os efeitos percebidos entre o aluno resolve as atividades e "o próprio aluno consegue resolver algumas atividades" reescreve a representação de aluno tradicionalmente pensado como aquele que não consegue resolver as atividades propostas sem a ajuda do professor e do livro didático.

As representações historicamente construídas de professor, de aluno e de livro didático podem também ser observadas nos dizeres de P10Q2 em resposta à mesma pergunta.

\section{S44 - P10Q2}

Eu explico o conteúdo e o aluno acompanha no livro. Não estou satisfeita pois os textos são muitos e longos, pouco vocabulário e uma atividade de áudio por unidade.

O professor é representado por P10Q2 como aquele que explica os conteúdos. Como efeito desse breve dizer, vemos o trabalho do professor como aquele que traduz, "explica", 
fazendo uma ponte entre os conteúdos do livro didático e o aluno. Os conteúdos do livro, então, são o centro da aula, o lugar de origem, de onde emanam os saberes que são trabalhados em aula. O aluno, por sua vez, "acompanha" suas explicações. Esses dizeres inevitavelmente nos remetem às imagens de uma aula tradicionalmente construída em que o professor ocupa o lugar daquele que tem acesso ao saber, pois tem o livro didático (o saber) em mãos, e faz a leitura dos conteúdos enquanto os alunos, "passivos", acompanham as explicações. Parece-nos, portanto, que a construção histórica das representações de professor, aluno e livro didático tem a força necessária para ainda sobreviver aos tempos, pois esses dizeres sobre o LDI do PNLD 2011 reescrevem as mesmas imagens tradicionalmente "naturalizadas" pelo trabalho da ideologia.

\subsection{Dizeres do discurso midiático}

Seguindo nosso objetivo neste capítulo de perceber se e como o LDI é representado como uma verdade no discurso que fala sobre ele, passamos a analisar o discurso midiático. Inicialmente, lembramos que o discurso midiático que analisamos, isto é, sobre o LDI, seleciona e reproduz o discurso oficial. Porém, é através do discurso da mídia que a sociedade em geral tem acesso aos dizeres do discurso oficial. Daí a importância de percebemos, através do discurso midiático, como são veiculadas à sociedade as representações construídas no/pelo discurso oficial. A primeira sequência discursiva pertence a uma matéria ${ }^{244}$ veiculada pelo site do curso Universitário do Rio Grande do Sul, postada logo após a publicação do Edital, em 19 de dezembro de 2008, e indica o MEC como fonte.

S45 - 19 dez. 2008

\section{Alunos terão livros de inglês e espanhol}

A partir de 2011, os alunos da rede pública dos anos finais do ensino fundamental (sexto ao nono ano) receberão livros didáticos de língua estrangeira (inglês e espanhol). A pré-inscrição das coleções e o cadastramento dos titulares de direito autoral junto ao Fundo Nacional de Desenvolvimento da Educação (FNDE), responsável pela compra das obras, vai de 12/01/09 a 27/03/09.

"É a primeira vez que vamos enviar livros de língua estrangeira para os alunos", lembra Sônia Schwartz, coordenadora geral dos programas do livro do FNDE, observando que já haviam sido distribuídos, anteriormente, livros de suporte para que os professores do ensino médio melhorassem o processo de aprendizagem em sala de aula. "Agora, distribuiremos para todos

\footnotetext{
${ }^{244}$ O texto integral da matéria encontra-se no ANEXO E. Disponível em: 〈http://www.universitario.com.br>. Acesso em: 21 jul. 2012.
} 
os estudantes dos anos finais do ensino fundamental e deveremos ampliar o atendimento para o ensino médio em 2012", afirma.

Pronúncia - Cada obra de língua estrangeira será acompanhada de um CD: "Ele é essencial para ensinar a pronúncia do inglês ou do espanhol", explica Sônia. Segundo ela, diversamente dos outros componentes curriculares, em que os livros devem ser utilizados por três anos consecutivos, os exemplares de língua estrangeira serão consumíveis: "O aluno vai poder escrever nele, já que será para seu uso exclusivo.” [...]

Como observa a coordenadora geral do Programa, no segundo parágrafo do artigo dessa matéria, antes do PNLD 2011, "livros de suporte" foram enviados aos professores do Ensino Médio, para que eles "melhorassem o processo de aprendizagem em sala de aula". O livro didático, portanto, é representado nesse dizer como um saber que faria o processo de aprendizagem melhorar.

Vemos que entre essa observação da coordenadora, relatada no artigo pelo site, e a próxima frase, em que a fala da coordenadora é reproduzida como citação, parece haver uma relação de causa e consequência. Ou seja, porque o livro didático já havia sido distribuído anteriormente aos professores "agora" a distribuição será ampliada aos alunos; desse modo, cada aluno terá seu próprio livro. Como efeito, observamos que a primeira distribuição (feita ao professor para melhorar a aprendizagem) parece ter tido o sucesso esperado e, assim, ocasionou a segunda ("para todos os estudantes dos anos finais do ensino fundamental") e a terceira distribuição (“deveremos ampliar o atendimento para o ensino médio em 2012”). Portanto, assim como a primeira, as distribuições consecutivas possivelmente também almejavam a melhora do "processo de aprendizagem em sala de aula". Porém, sendo a primeira distribuição apenas aos professores, observamos que o resultado que poderia ser esperado seria no processo de ensino em primeiro lugar; posteriormente, talvez, no processo de aprendizagem, como consequência. Isso porque o livro usado como "suporte" pelo professor teria seu maior impacto no ensino e não exatamente nem em primeira instância na aprendizagem.

Como nada é alterado ou acrescido ao dizer em relação às outras distribuições, o mesmo efeito de troca de palavras pode ser percebido, ou seja, o emprego da palavra aprendizagem no lugar onde mais caberia a palavra ensino. Desse modo, as demais distribuições, mesmo que agora contemplem o aluno, têm, como analisamos acima, o mesmo objetivo: melhorar o processo de ensino e, também, de aprendizagem, que adquire, aqui, um estatuto de consequência do processo de ensino. Portanto, a aprendizagem da língua inglesa é 
representada como resultante direta do processo de ensino. Isto é, parece haver uma relação direta entre ensinar e aprender, sem que se considere a aprendizagem como um processo que, apesar de poder ser posto em funcionamento através do processo de ensino, tem suas peculiaridades. O não reconhecimento da aprendizagem como um processo com características próprias e marcado, também, pelas características pessoais de cada aluno acaba por representar o ensino de língua inglesa como sendo um processo sem falhas, isto é, infalível, em que tudo que se ensina é aprendido por todos e do mesmo modo. Esse recobrimento de um processo pelo outro dissimula a necessidade de planejamentos próprios, isto é, direcionados a cada um dos processos individualmente e nas relações entre eles. Evitase, assim, no planejamento dos programas, a investigação da relação indireta que existe entre ensinar e aprender.

O mesmo efeito de troca de palavras entre ensinar e aprender pode ser percebido no terceiro parágrafo, com o subtítulo de Pronúncia. De acordo com a explicação da coordenadora informada pelo site, o CD que acompanha o livro didático "é essencial para ensinar a pronúncia do inglês ou do espanhol".

Para ensinar a pronúncia, mesmo que não se ensinem os aspectos formais, é essencial, diríamos, conhecer os aspectos linguísticos relativos à fala dessa língua; não apenas os mais teóricos, como a fonética (sons e suas particularidades acústicas e perceptivas), a fonologia (resumidamente, as diferenças fônicas), mas também os aspectos práticos como variações regionais. Isso porque o oferecimento de atividades orais que apresentassem variações regionais e não privilegiasse apenas um tipo de variação foi um critério exigido no Edital para a elaboração das coleções didáticas. Segundo o Edital,

\footnotetext{
As variedades regionais, culturais, sociais, etárias e étnicas da língua escrita e falada, bem como as ligadas ao suporte ou meio em que são veiculadas as mensagens, não devem, portanto, ocupar um espaço marginal nas coleções de Língua Estrangeira, mas ser tratadas, de forma contextualizada, como elemento constitutivo da língua, levando em conta as consequiências de seus usos públicos e privados. [sic]
}

Desse modo, parece-nos que o CD traz muitas contribuições à aprendizagem, com o oferecimento de modelos de fala em palavras isoladas, textos e diálogos, e não exatamente ao ensino da pronúncia em língua inglesa, pois, o $\mathrm{CD}$ do professor é o mesmo do aluno. Não observamos, nem no Edital nem no Guia, qualquer referência à necessidade de o material de áudio incluir informações específicas ao professor sobre o ensino da pronúncia. Em relação ao CD, no Edital, lemos: 


\section{DA CARACTERIZAÇÃO DAS COLEÇÕES DIDÁTICAS}

3.5. As coleções de Língua Estrangeira Moderna (Língua Inglesa e Língua Espanhola) deverão ser acompanhadas, obrigatoriamente, de um CD de áudio e este será considerado parte integrante da obra.

$\mathrm{Na}$ introdução do Guia, temos a seguinte informação:

Para o aluno, além do contato com o professor e da experiência de sala de aula, os livros e os CDs das coleções didáticas terão um papel importante no processo de aprendizagem da língua estrangeira em sua totalidade, servindo-lhe como instrumentos confiáveis e sempre à sua disposição. Esse material deve dar ao aluno condições de aprender a ler, escrever, ouvir e falar na língua estrangeira.

Para o professor, esse material será um valioso suporte no planejamento e na execução de suas aulas.

Por sua vez, as resenhas informam:

O CD de áudio apresenta boa qualidade de som e existem, no Livro do Aluno e no Manual do Professor, indicações precisas que facilitam a localização das faixas.

Desse modo, o ensino da pronúncia parece contar com os efeitos de transparência e de evidência da língua em relação à compreensão e à produção oral em língua estrangeira, como se bastasse ouvir a língua falada para imediatamente compreendê-la e (re)produzi-la. Essa concepção de oralidade apaga a necessidade do trabalho com técnicas e práticas para o ensino e a aprendizagem de pronúncia em inglês e acentua a ilusão do aprendizado intuitivo pela relação direta que estabelece entre ouvir, entender e falar. Portanto, tanto o LDI como o CD são representados nesses dizeres que analisamos como saberes que farão o processo de aprendizagem, do professor e do aluno, melhorarem naturalmente, isto é, sem o necessário investimento na formação do professor e sem o trabalho constante e pontual do professor junto aos alunos.

Analisaremos, a seguir, os dizeres que pertencem à reportagem intitulada Livro didático - Programa terá este ano aquisição recorde de 135 milhões de exemplares, postada em 25 de fevereiro de 2011 no site www.brasileiracity.com. br $^{245}$.

S46 - 25 fev. 2011

Desafios - Na avaliação do diretor de políticas de formação, materiais didáticos e de tecnologias para educação básica do MEC, Marcelo Soares, a distribuição de livros didáticos,

${ }^{245}$ Cf. <http://www.brasileiracity.com.br/?pagina=5\&coluna=educacao $>$. Acesso em: 25 fev. 2011. 
aliada a políticas como a de valorização do magistério, tem contribuído, ${ }^{246}$ para a elevação da qualidade da educação no país. Ele salienta que o Brasil aparece entre os três países que mais evoluíram na educação básica nesta década, segundo relatório do Programa Internacional de Avaliação de Alunos (Pisa) de 2009, divulgado no ano passado.

Sublinhamos a parte do excerto que se refere ao livro didático, para percebermos como esse material é representado no discurso da mídia. Apesar de neste excerto a reportagem não tratar especificamente do livro didático de inglês, esse material se inclui entre os títulos da "aquisição recorde de 135 milhões de exemplares".

Nessa sequência discursiva, vemos que, além da "valorização do magistério", é a distribuição do livro didático que contribui para elevar a qualidade da educação no Brasil. Nesse dizer, a falta de adjetivação do livro didático produz o efeito de que qualquer livro didático é capaz de contribuir para a melhoria da educação. Ou seja, não se trata de primar pela qualidade do livro didático - e aqui também o LDI se inclui - nem prover meios para suprir as necessidades dos sujeitos envolvidos no processo educacional de acordo com seus objetivos, considerando a complexidade das diferenças regionais; pois, a distribuição do livro didático é já suficiente para elevar a qualidade da educação. Vemos, portanto, que o LDI é representado nesse dizer como uma verdade que deve chegar pronta às mãos dos alunos e dos professores, como um saber que se quer todo, completo e capaz de melhorar a qualidade da educação apenas por ser distribuído em âmbito nacional.

É preciso dizer ainda que a distribuição do livro, segundo o dizer do excerto, deve estar "aliada a políticas como a de valorização do magistério". Como sabemos, a "valorização do magistério" produz o efeito de sentido naturalizado, guardado na memória do enunciado: salários justos aos professores. Sabemos que o discurso sobre os baixos salários dos professores é recorrente nas reportagens, como se ele existisse apenas para padronizar todos os assuntos sobre educação no Brasil, pois não há medidas efetivas imbuídas de vontade política para sanar a defasagem salarial dos professores. A repetição constante e vazia desse dizer acaba apagando o fato de que a "valorização do magistério" não deve remeter apenas à questão salarial. Além do salário digno, é preciso haver medidas que favoreçam a formação e a atuação do professor como pesquisador que é.

\footnotetext{
${ }^{246}$ A matéria original, sob o mesmo título, foi publicada no site do MEC às 18 horas e 9 minutos do dia 25 de fevereiro de 2011 e assinada por Ana Guimarães. O texto que apresentamos foi publicado pela referida agência de notícias poucas horas depois, às 23 horas e 20 minutos. No texto do MEC, essa vírgula após "contribuído" não existe. Não foram encontradas outras divergências entre o texto da agência e o texto original do MEC.
} 
Portanto, ao sustentar que a melhoria da educação depende apenas da distribuição de livros didáticos e de melhores salários aos professores, o discurso midiático, como reprodução do discurso oficial, considera apenas o lado material e secundário do processo. Isto é, para termos livros para a distribuição, antes é preciso elaborá-los, observando a complexidade do papel que ele irá assumir no contexto educacional brasileiro; para termos professores, é preciso que a carreira seja atraente economicamente e instigante profissionalmente. Vemos, então, que o discurso midiático continua, também nesse dizer, se ausentando de questionar aquilo que torna público; pois, na opacidade do discurso, apenas faz ressoar antigos enunciados, concordando com o discurso oficial que a melhoria da educação brasileira se fará com a distribuição de dinheiro aos professores e de livros aos alunos.

A próxima sequência discursiva recorta o primeiro, o segundo e o sexto parágrafos de uma reportagem com sete parágrafos ${ }^{247}$.

S47 - 10 mar. 2011

\section{Escolas estaduais entregam livros didáticos nesta sexta-feira em momento cívico}

Os educadores da Escola Estadual Vila União fizeram na manhã desta sexta-feira, 11, a entrega dos livros didáticos, com momento cívico, apresentação de vídeo sobre 'o cuidado com o livro didático', realização de uma oficina sobre encapar livros e lançamento da ação 'melhor leitor do ano de 2011".

Na Escola Estadual São José, localizada na Quadra 1106 sul, em Palmas, serão realizadas duas palestras sobre a importância da leitura, uma às 14h30, com o estudante de Pedagogia da UFT, Márcio Frota e outra com a psicóloga Vera Aparecida Benedito, às 16 horas.

[...]

A novidade este ano, é que os alunos do ensino fundamental vão receber livros de Língua Inglesa e Espanhol, são livros consumíveis, isto é, os exemplares ficarão para os alunos. $[\ldots]$

É interessante observar nessa reportagem a associação feita entre a entrega dos livros didáticos do PNLD 2011 e a comemoração dessa entrega em um "momento cívico". De início, a realização de uma comemoração - com a apresentação de filme em vídeo, oferecimento de oficina e, em outra escola, duas palestras - marca a entrega dos livros didáticos do PNLD 2011 aos alunos como um evento solene. Esse evento é referido no título e também no texto da reportagem como um "momento cívico". O adjetivo cívico relaciona-se à demonstração de patriotismo, um ato realizado em honra à pátria. Como efeito, percebemos, então, que tanto os educadores que entregam quanto os alunos que recebem os livros didáticos estão, nesse momento, praticando um ato de patriotismo, honrando a pátria. Nesse ato cívico,

\footnotetext{
${ }^{247}$ Veja o texto integral no ANEXO F. Disponível em: < http://www.portalct.com.br/>. Acesso em: 30 mai. 2010.
} 
o livro didático é o objeto que se entrega e se recebe e que, portanto, representa um objeto com o qual se honra a pátria. Percebemos, aí, o valor de verdade atribuído ao LD e também ao LDI, incluído na entrega em 2011, como informa o artigo na sequência acima. Um objeto de verdade, de saber, que deve ser cuidado. Assim, nesse "momento cívico", ensina-se e aprende-se a cuidar do livro com a apresentação de um vídeo e com uma oficina sobre como encapá-lo para protegê-lo. Parece-nos, portanto, que a representação do LDI como um conjunto de procedimentos que deve ser regulado e protegido encontra aqui também forte respaldo. Nesse momento, o livro didático é representado não somente como um saber qualquer, mas um saber que é uma verdade nacional, uma verdade garantida e legitimada pela pátria.

\section{Considerações sobre o capítulo}

Propusemo-nos a buscar, neste capítulo, momentos em que o controle regulador do funcionamento do LDI pudesse ser percebido no discurso sobre o LDI; pois, acreditamos que o LDI comporta um conjunto de procedimentos que devem ser regulados para que os enunciados funcionem e circulem como verdades. Como discutimos sobre a concepção foucaultiana de saber e poder, o controle deseja garantir a estabilidade dos enunciados que circulam socialmente como um saber, como a verdade.

$\mathrm{Na}$ análise dos dizeres do discurso oficial sobre o LDI, vimos que há um grande desejo de garantir a produção e a circulação dos enunciados que carregam os valores a serem mantidos e/ou estabelecidos em nossa sociedade. Parece-nos que o LDI funciona como um importante objeto simbólico; pois, como vimos, é falado em um discurso marcado pela elaboração cuidadosa e laboriosa para garantir que o LDI seja mantido como verdade, assegurando desde uma escolha que não existe até a aceitação de um critério que não seria inicialmente aceito, como no caso da isenção de erros. Vimos, também, que a relação de coleções pré-aprovadas funciona como um meio regulador dos materiais que podem circular na sociedade. Discutimos, ainda, o funcionamento da argumentação como efeito dos dizeres de três épocas. Para isso, tomamos os dizeres inscritos no primeiro livro didático usado no Brasil, como dizeres inseridos na sociedade de soberania, o Decreto-lei n. 8.460 de 1945, como dizeres da sociedade disciplinar, e um excerto do Guia de Livros Didáticos do PNLD de 2011, como característico do momento atual e que apresenta um funcionamento aos moldes da sociedade de controle. Percebemos que a materialidade linguística desses dizeres carrega as marcas características do funcionamento de cada uma dessas sociedades. 
Também a análise dos dizeres do discurso profissional nos possibilitou a percepção da representação do LDI como uma verdade. Para alguns sujeitos, a verdade existe, pode ser trabalhada e até encontrada em algum lugar, em um LDI ideal. Para outros, o LDI do PNLD 2011 já é essa verdade. A crença na existência da verdade leva ao alívio do fardo do professor com a chegada do LDI do PNLD ou à procura interminável por diferentes tipos e gêneros de materiais didáticos, como materiais autênticos ou produzidos a partir de muitos outros, pois, assim, acredita-se estar diante da verdade.

Podemos concluir que também o discurso midiático representa o LDI como uma verdade; pois, nos dizeres analisados, a disponibilização do LDI e do CD ao professor e ao aluno, a distribuição do livro didático, juntamente com a valorização do magistério, são já suficientes para elevar a qualidade da educação no Brasil. A verdade, o saber, que o livro didático representa é tão capaz de melhorar o ensino que não é necessário saber de que livro didático se trata, como ele foi elaborado, que informações ele traz, quais sentidos ele estaria naturalizando, quais princípios ele promove etc., para concluir-se que sua distribuição recorde contribuirá significativamente para melhorar o aprendizado e elevar a qualidade da educação no Brasil.

Observamos, também, na materialidade linguística, a contribuição da modalização como meio de garantir o adiamento do término e oferecer linhas de fuga, que apontam a possibilidades de sentido, enquanto o dizer trabalha para garantir o sentido desejado. $\mathrm{O}$ deslize de "erros" a "erros significantes" e a "falhas" ameniza e modaliza os dizeres das resenhas. A modalização foi também percebida no contraste que fizemos entre os dizeres produzidos em três épocas: na sociedade de soberania, disciplinar e de controle. Nos dizeres que associamos à época da sociedade de controle, vimos que a modalização dos elementos argumentativos, com o uso de suavizações ("Recomenda-se") e justificativas ("Dessa forma", "além de", "a fim de que" etc.), assegura o adiamento do fim, através de processos contínuos e intermináveis, e garante outras possibilidades, alternativas e linhas de fuga. Portanto, a modalização opera o jogo entre aquilo que por ser recomendado deve ser seguido, como o sentido que deve prevalecer, e todas as possibilidades de recusa dessa recomendação, justamente por ser algo apenas recomendado.

Esse capítulo nos ajudou a perceber que a representação do LDI como uma verdade, que o discurso sobre o LDI trabalha para proteger, permanece frágil na materialidade discursiva. Isso porque a discursivização da verdade encontra-se ora em relação ao LDI do PNLD 2011, ora em relação a um LDI ideal, inatingível, imaginário. A fragilidade da representação do LDI como verdade possibilitou à análise a percepção da opacidade que 
aponta aos diferentes funcionamentos das práticas discursivas em relação às práticas nãodiscursivas, como no caso da "escolha". Isto é, observamos que o discurso da escolha, mesmo funcionando como prática discursiva, não encontra respaldo numa prática não-discursiva. 


\section{CAPÍTULO 6}

\section{A ARTICULAÇÃO DA RELAÇÃO SABER-PODER}

Neste capítulo, procuramos perceber, nos dizeres do corpus de pesquisa, a articulação entre saber e poder no movimento circular que caracteriza essa relação. A percepção dessa articulação ou, mais especificamente, a compreensão de como, no discurso sobre o LDI, poder e saber são articulados nos permitirá caracterizar o discurso sobre o LDI como um modo de investimento de poder sobre o LDI, representando-o socialmente como um discurso de verdade. Este capítulo é, portanto, essencial para nossa pesquisa uma vez que ele concentra o foco de nossa investigação, apesar de não prescindir dos dois capítulos de análise que o antecederam. A terceira categoria de análise, a articulação entre saber-poder, poderá nos fornecer elementos para verificar nossa hipótese de que o LDI não funciona como um discurso de verdade por si; ao contrário, o discurso que fala sobre o LDI investe poder nesse material ao representá-lo como portador da verdade, isto é, produzindo-o discursivamente como verdade.

Para entendermos esse movimento, observaremos, nos dizeres, nossa terceira categoria de análise, partindo da definição foucaultiana (FOUCAULT, M., ([1982] 1995, p. 243) ${ }^{248}$ de uma relação de poder:

De fato, aquilo que define uma relação de poder é um modo de ação que não age direta e imediatamente sobre os outros, mas que age sobre sua própria ação. Uma ação sobre a ação, sobre ações eventuais, ou atuais, futuras ou presentes.

A partir dessa definição, deveremos ainda considerar que, sobre esses outros, Foucault ([1982] 1995, p. 243) diz, mais adiante no mesmo parágrafo:

[...] uma relação de poder, ao contrário, se articula sobre dois elementos que lhe são indispensáveis por ser exatamente uma relação de poder: que "o outro" (aquele sobre o qual ela se exerce) seja inteiramente reconhecido e mantido até o fim como o sujeito de ação; e que se abra, diante da relação de poder, todo um campo de respostas, reações, efeitos, invenções possíveis.

\footnotetext{
${ }^{248} \mathrm{O}$ texto em inglês se encontra no capítulo três deste trabalho.
} 
Portanto, nossa terceira categoria de análise deverá ser subdividida, para considerar os dois elementos indispensáveis para essa articulação: o outro em sua condição de ser "inteiramente reconhecido e mantido até o fim como o sujeito de ação", ou seja, uma pessoa que age, e a possibilidade de se abrir "todo um campo de respostas, reações, efeitos, invenções". Como argumentamos no capítulo três, a análise do discurso sobre o LDI considerará o professor (ou seja, a representação de professor de inglês construída no/pelo discurso sobre o LDI) na condição de ser esse outro, definido por Foucault na citação acima como "aquele sobre o qual ela [uma relação de poder] se exerce". Deveremos, então, perceber se o professor é representado como uma pessoa que age e se o discurso sobre o LDI observa a possibilidade de se abrir "todo um campo de respostas, reações, efeitos, invenções".

Entendemos que, ao estabelecer essas duas condições para a articulação de uma relação de poder, Foucault reafirma a necessidade de inclusão do elemento essencial dessa relação: a liberdade. Diz Foucault ([1982] 1995, p. 244), “O poder só se exerce sobre 'sujeitos livres"”. Assim, ao ser representado como uma pessoa que age, o professor estará sendo considerado como um "sujeito livre".

Do mesmo modo, o segundo elemento (a possibilidade de se abrir "todo um campo de respostas, reações, efeitos, invenções") também considera a liberdade de ação como aquilo que garante uma relação de poder; pois, segundo Foucault ([1982] 1995, p. 248), "não há relação de poder sem resistência, sem escapatória ou fuga". Considerando que, para Foucault, ser "livre" não significa estar fora de relações de poder, mas estar suscetível a novas formas de assujeitamento, podemos entender essa necessária consideração da liberdade se pensarmos que toda relação de poder acomoda em si a possibilidade de resistência e, portanto, de ação.

Em relação a Deleuze, lembramos que as linhas de fuga, como aquilo que desorganiza e desestratifica o rizoma, não param de se remeter umas às outras e às linhas de segmentaridade, que organizam e estratificam o rizoma. Este é, dentre os seis princípios básicos ${ }^{249}$ do rizoma, o primeiro: o Princípio de conexão (DELEUZE, G.; GUATTARI, F., [1980] 1995). Considerando que todos os princípios $^{250}$ que regem o rizoma estão interligados de algum modo, observamos que o Princípio de conexão garante o Princípio de ruptura assignificante $^{251}$, do qual não se depreende qualquer processo de significação. Isto é, a não estabilização da significação nesse sistema aberto do rizoma não se detém em dicotomias, num batimento entre isso e aquilo; no rizoma a significação é multiplicidade. Em relação ao

\footnotetext{
${ }^{249}$ Cf. DELEUZE, G.; GUATTARI, F., [1980] 1995.

${ }^{250}$ Como descrevemos no item 2.2.

${ }^{251}$ Idem, p. 15.
} 
funcionamento do poder na sociedade de controle, parece-nos que as linhas de fuga, ao apontarem para outras direções, desestratificando e desterritorializando o rizoma, estariam abrindo espaço para a resistência. Porém, no movimento incessante da trama do rizoma, essas linhas retornam a outras linhas de fuga e às linhas de segmentaridade, reorganizando e reestratificando o rizoma. A resistência que poderia se conformar a uma linha de fuga é reabsorvida numa linha de segmentaridade, para depois explodir novamente em outra linha de fuga e assim por diante. Nesse funcionamento rizomático das estratégias do poder, parece-nos que a existência de linhas de fuga asseguram o controle justamente por oferecerem a possibilidade de fuga, pois, segundo Deleuze ([1990] 2008, p. 218), "É ao nível de cada tentativa que se avaliam a capacidade de resistência ou, ao contrário, a submissão a um controle".

Analisaremos agora os dizeres, observando a terceira categoria de análise subdividida em:

a) o poder é exercido sobre uma pessoa que age;

b) diante de uma relação de poder, há a possibilidade de se abrir "todo um campo de respostas, reações, efeitos e invenções".

\subsection{Dizeres do discurso oficial}

O primeiro excerto pertence ao documento Orientações para o Registro da Escolha do PNLD 2011 ( $6^{\circ}$ ao $9^{\circ}$ ano), que divulgou os procedimentos para que as escolas, via gestor local, pudessem aderir ao programa e, posteriormente, receber os livros. Como já informamos anteriormente, esse documento foi disponibilizado às escolas através da Carta Circular n. ${ }^{\mathbf{0}}$ 04/2010, de quatro de abril de 2010, emitida pelo MEC/FNDE. O último dos onze itens, Normas de Conduta no Âmbito da Execução dos Programas do Livro (originalmente em negritos) apresenta apenas um subitem, que remete à Portaria Normativa $\mathbf{n}^{\mathbf{0}} \mathbf{7}$ de 5 de abril de 2007. Vejamos ambos os excertos.

ORIENTAÇÕES PARA O REGISTRO DA ESCOLHA DO PNLD $2011\left(6^{\circ}\right.$ ao $9^{\circ}$ ano) [...] 11. NORMAS DE CONDUTA NO ÂMBITO DA EXECUÇÃO DOS PROGRAMAS DO LIVRO:

11.1. Devem ser observadas e respeitadas as normas de conduta, disponíveis no portal www.fnde.gov.br > Livro Didático >> Legislação > 2007 > Portaria Normativa n 7. 
Nessa Portaria Normativa $\mathbf{n}^{\circ} \mathbf{7}^{252}$, o primeiro parágrafo do Artigo 3 estabelece as obrigações do MEC e do Fundo Nacional de Desenvolvimento da Educação em cinco itens.

S49

$\S 1^{\circ}$ Constituem-se obrigações do MEC e do FNDE:

I - divulgar a forma e o atendimento dos Programas do Livro por meio do site www.fnde.gov.br, ou do Diário Oficial da União, ou de correspondências específicas aos participantes dos programas, no que couber;

II - promover e apoiar ações voltadas para a formação docente com vistas à escolha e ao uso do livro nas Escolas;

III - garantir a isonomia do processo de execução, não disponibilizando informações que privilegiem um ou outro Titular de Direito Autoral;

IV - adotar as providências cabíveis no caso de as Secretarias de Educação e os Titulares de Direitos Autorais que infringirem as normas de conduta;

$\mathrm{V}$ - identificar claramente a propriedade do material do MEC/FNDE, na primeira capa dos guias de escolha e nos demais materiais oficiais distribuídos.

Notamos, inicialmente, que quatro dos cinco itens desse parágrafo em S49 tratam de medidas práticas e objetivas, de cunho administrativo e jurídico, em relação à divulgação do programa (item I), à garantia de isenção de privilégios (III), à punição aos infratores (IV) e à divulgação do nome do MEC e do FNDE, que devem constar nas capas de todos os materiais (V). O item dois, no entanto, salta aos olhos pela discrepância de seu conteúdo em relação aos demais. Isto é, o item dois atribui como sendo obrigação do MEC e do FNDE tomar parte em ações que visam formar docentes para a escolha e para o uso do livro didático nas escolas. Portanto, são medidas de cunho político-pedagógico ou político-educacional transitando discursivamente em meio a medidas de cunho administrativo e jurídico. Assim, esses dizeres produzem o efeito de que formar os professores para escolher e usar o livro didático na escola é também uma ação simples, objetiva e prática, e, mais importante, de cunho administrativo e jurídico, além de pertencer ao rol de obrigações desses órgãos públicos. Além disso, essas ações que o MEC e o FNDE devem promover e apoiar não incidirão diretamente sobre os professores, mas sobre suas ações, lembrando a citação de Foucault, "ações eventuais, ou atuais, futuras ou presentes"; isto é, ações existentes ou que possam surgir, ou seja, num primeiro momento, escolher e, depois, usar o livro nas escolas. Os dizeres do item II, portanto, parecem se caracterizar como um modo de ação (promover e apoiar ações) sobre outras ações (escolher e usar), produzindo discursivamente a representação de professor como uma pessoa que age, pois escolhe e usa. Apesar de afirmar que a "escolha e o uso do

${ }^{252}$ Veja ANEXO A, para o texto integral dessa portaria. 
livro na Escola" serão frutos das ações administrativas e jurídicas do MEC e do FNDE que incidirão sobre a "formação docente", o professor é aquele que, em última instância, fará a "escolha" e o uso desse material com seus alunos. Desse modo, o professor é mantido, ao menos na opacidade discursiva, "até o fim como um sujeito de ação", uma pessoa que age.

O termo "formação docente" toma o lugar da palavra "professor" em meio a esse atravessamento do discurso jurídico-administrativo, produzindo o efeito de ênfase na capacitação profissional e não exatamente no professor como participante, atuante, no processo educacional. A partir dos dizeres desse excerto, não se supõe que essa "formação docente" seja compreendida como uma formação acadêmica, nem técnica voltada ao ensino, que deveria estar fundamentalmente inscrita na esfera político-pedagógica ou políticoeducacional; pois, a "formação docente", aqui, tem o objetivo estrito de capacitar o professor a escolher e a usar o livro na escola. Essa representação de "formação docente", de algum modo, ecoa também nos dizeres de alguns professores (P5Q1, por exemplo) e na sociedade, como um dizer naturalizado, que sustenta a imagem de professor como aquele que apenas usa o material didático. Temos, ainda, outros traços identitários de professor: aquele cuja formação, promovida e apoiada pelo MEC e pelo FNDE, possibilita que ele escolha e use o livro didático de língua estrangeira.

Atentando aos tipos de ações em questão nesse dizer, vemos que as ações atribuídas aos órgãos públicos são promover (gerar, dar início, originar) e apoiar (acolher, aprovar, favorecer). Ou seja, o MEC e o FNDE têm a obrigação de gerar e acolher ações que capacitem o professor a escolher e a usar o livro didático. Sem isso, o professor não possui tal “formação", ou seja, não está capacitado a escolher nem a usar o livro didático na escola.

Embora as ações atribuídas ao professor sejam escolher e usar, sabemos que essa "escolha" do professor já foi limitada para apenas duas coleções, previamente selecionadas dentre as 26 submetidas à avaliação. Além disso, como já discutimos, ambos os títulos sugeridos deveriam ser "escolhidos". É importante ressaltar, também, que foi amplamente divulgado pelo FNDE $^{253}$ que, na indisponibilidade da coleção escolhida pelo professor, a outra coleção lhe seria enviada. Ou seja, mesmo tendo indicado uma das coleções como sua primeira opção, o professor poderia ainda receber a segunda, como dissemos anteriormente. É o caso de perguntar qual o sentido de escolha nesse caso.

\footnotetext{
${ }^{253}$ Como analisamos anteriormente no item 5.1.2, o documento constante da Carta Circular n. 4, Orientações para o Registro da Escolha do PNLD 2011, item 7.3, informa: "Caso não se concretize a aquisição com a editora da $1^{\mathrm{a}}$ opção, serão enviados os livros da $\mathbf{2}^{\mathrm{a}}$ opção. Por esse motivo, a escolha da $2^{\mathrm{a}}$ opção precisa ser tão cuidadosa quanto à da $1^{\text {a"” }}$.
} 
A ação esperada a partir do verbo usar é a mais intrigante nesse dizer. Isso porque usar um livro didático não é uma ação tão simples e objetiva, nem invoca um sentido único, como o dizer parece sugerir, nem tampouco é algo que possa ser aceito como fruto de ações jurídico-administrativas promovidas e apoiadas por órgãos públicos. Vemos, então, que esse dizer produz o efeito de que o trabalho do professor se reduz a usar "o livro na escola" de acordo com as determinações do MEC e do FNDE.

Podemos dizer que há aí um grande investimento de poder no LDI, fazendo com que ele funcione como uma verdade legitimada que o professor deverá pôr em circulação "na Escola". Esse trabalho do professor é percebido como algo simples e objetivo, pertencente à sua formação que é, por sua vez, gerada, acolhida e favorecida pelas ações dos órgãos públicos. Ou seja, o uso que o professor fará do livro aparece já discursivamente prédeterminado por esses órgãos.

Assim, vemos que as ações desses órgãos não incidem diretamente sobre o professor, mas sobre sua "formação", a "formação docente"; isto é, sobre o modo de o professor agir. Apesar de ambas as ações, escolher e usar o livro, já estarem de algum modo prédeterminadas pelas ações desses órgãos, elas garantem, ao menos discursivamente, que o professor seja mantido como uma pessoa que age ao mesmo tempo em que observa a possibilidade de se abrir "todo um campo de respostas, reações, efeitos, invenções"; pois, na transparência ilusória do dizer do discurso oficial, o professor é quem escolherá e usará o LDI.

Como dissemos no item 5.1.1, a sequência discursiva referente ao Anexo X, parte do Edital de Convocação para Inscrição no Processo de Avaliação e Seleção de Coleções Didáticas para o Programa Nacional do Livro Didático - PNLD 2011, será analisada também neste capítulo seis, porém brevemente. A introdução ao Anexo X diz:

S50

ANEXO X - PRINCÍPIOS E CRITÉRIOS PARA A AVALIAÇÃO DE COLEÇÕES DIDÁTICAS DESTINADAS AOS ANOS FINAIS DO ENSINO FUNDAMENTAL

O PNLD cumpre a função, também, de estimular a discussão e participação de professores na escolha dos materiais didáticos a serem utilizados na escola, contribuindo dessa forma para o exercício competente de sua profissão.

Nos dizeres dessa sequência discursiva, vemos que o estabelecimento de uma função do PNLD desencadeia uma série de ações: "estimular a discussão e participação de 
professores na escolha dos materiais didáticos a serem utilizados na escola". Vejamos o esquema abaixo.

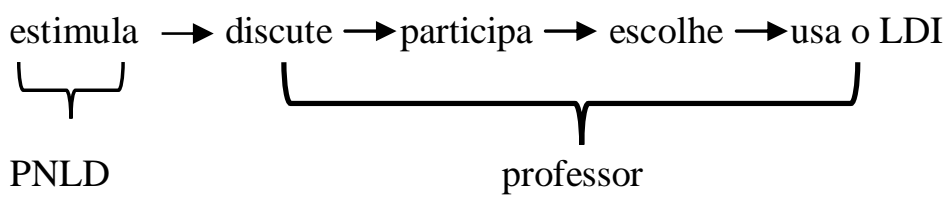

Através do esquema, podemos observar, como efeito discursivo, que uma única ação do Programa (estimular) pode desencadear uma série de quatro ações do professor (discutir, participar, escolher e usar o LDI). Na continuação do dizer do Edital, temos ainda: "contribuindo dessa forma para o exercício competente de sua profissão", como esquematizamos abaixo.

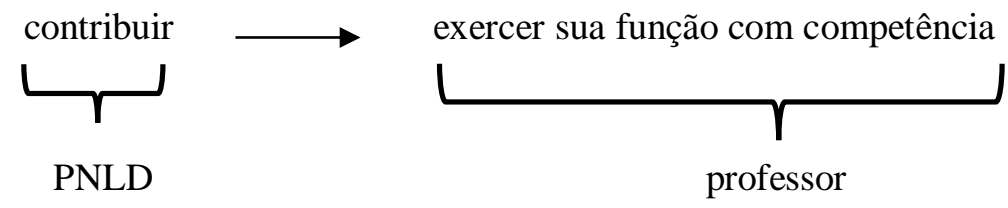

Em ambos os esquemas, portanto, temos o efeito que investigamos neste capítulo: a articulação de uma relação de poder. Inicialmente, observamos o movimento de uma ação sobre outra (conforme a definição foucaultiana de poder) nos dois esquemas que propusemos para representar os dizeres da introdução do Anexo X, ou seja, a ação do PNLD sobre as ações do professor. Considerando o primeiro elemento indispensável para uma relação de poder, vemos que o professor é mantido discursivamente como uma pessoa que age, pois discute, participa, escolhe, usa o LDI, e exerce sua função.

Já o segundo elemento necessário para observarmos uma relação de poder (a possibilidade de se abrir "todo um campo de respostas, reações, efeitos e invenções"), apesar das tentativas de assegurar tanto a escolha como o uso do LDI, como vimos, esse "campo" de ações se mantém aberto. Isso porque o professor, como uma pessoa que age, poderá ainda encontrar uma linha de fuga e não aderir ao programa de adoção do LDI. Como informamos anteriormente, dentre os vinte e oito professores que responderam ao segundo questionário de pesquisa, três não adotaram os livros do PNLD 2011 e dois adotaram outras coleções didáticas.

Observamos ainda nessa sequência discursiva que o PNLD "cumpre a função". Esse dizer produz o efeito de que também o Programa se encontra num movimento de ação sobre 
ação, pois "cumpre", segue, obedece, uma "função" estabelecida por outro em outro lugar. Porém, esse outro que determina a função do Programa, mesmo pressuposto, não é informado nesse momento. Vemos que a omissão dessa informação não funciona como um apagamento, visto que é pressuposta pela hierarquia organizacional do Programa. Essa omissão pode estar funcionando, então, como uma modalização do dizer ao deixar em aberto e indeterminando o responsável pelo estabelecimento dessa função que se cumpre. Cumprir uma função, cumprir um papel, é executar uma ação repassada por outro e não requer necessariamente a crença nessa função, nesse papel.

Mesmo que esse efeito que percebemos no dizer não traga consequências práticas à execução do programa em si, isto é, não resulte em práticas não-discursivas que possam de algum modo destoar daquilo que fora inicialmente pensado pelo responsável de fazer cumprir essa função, sua importância nesse momento é bastante relevante à nossa pesquisa. Isso porque, segundo Deleuze, é possível que o modo de funcionamento das sociedades de controle recupere os meios das sociedades de soberania. De acordo com Deleuze ([1990] 2008, p. 225), "Pode ser que meios antigos, tomados de empréstimo às antigas sociedades de soberania, retornem à cena, mas devidamente adaptados”. Deleuze relaciona a sociedade disciplinar aos meios de confinamento e a sociedade de soberania ao açambarcamento, ou seja, ao ato de monopolizar ou tomar tudo para si, e "decidir sobre a morte mais do que gerir a vida” (DELEUZE, G., ([1990] 2008, p. 219).

Com essa argumentação, Deleuze ([1990] 2008, p. 225) parece afirmar que na sociedade de controle, há também o açambarcamento; porém, acreditamos que esse meio ou modo de funcionamento é agora modalizado, suavizado ou, como sugere Deleuze, “devidamente adaptado". No dizer que analisamos, a função que o PNLD cumpre tem como fim a escolha dos materiais didáticos. Passando pela função de estimular a discussão e a participação dos professores, a função do PNLD é agir para que a escolha aconteça e os materiais sejam usados na escola. Isto é, todas as ações desse dizer têm como finalidade última a escolha do material para que ele, sendo escolhido, seja usado em aula. Ou seja, uma vez escolhido é aquele que será usado; portanto, a ação de usar é já determinada pela ação de escolher. Por isso, as demais ações (estimular, discutir, participar) são acionadas pela função que o PNLD cumpre e findam na escolha (e no uso como consequência da escolha).

Porém, como vimos no capítulo anterior, a escolha não existiu, pois as duas opções já estavam destinadas à adoção. O trabalho discursivo desse dizer pode, então, ser percebido como: 1) na transparência ilusória do dizer, fazer crer que a escolha exista e que será respeitada e 2) na opacidade do dizer, modalizar (sempre no sentido de suavizar) uma ação 
soberana. Defendemos, então, que é na modalização que o dizer garante discursivamente o segundo elemento necessário para a articulação de uma relação de poder: a possibilidade de se abrir "todo um campo de respostas, reações, efeitos e invenções" (FOUCAULT, M., [1982] 1995, p. 243).

Analisamos, a seguir, os dizeres dos respondentes aos questionários de pesquisa.

\subsection{Dizeres do discurso profissional}

Para esta terceira categoria de análise, reservamos as respostas dos professores à quarta pergunta do primeiro questionário:

4) Em sua opinião, de que modo o livro didático poderá (ou não) contribuir para o ensino de inglês como língua estrangeira na escola pública? Quais são as vantagens e/ou desvantagens?

Em resposta a essa pergunta, o primeiro professor (P1Q1, novamente) escreveu:

$$
\text { S51 - P1Q1 }
$$

Facilitando a vida do professor e aluno.

vantagem - unificar o ensino da língua, tendo a sequência do que foi ensinado nos anos seguintes

desvantagem - o professor, na minha opinião, não deveria ficar somente preso a um único livro, mas também utilizar outros recursos e talvez ficasse um pouco acomodado e não utilizaria outro material.

P1Q1 inicia sua resposta com um verbo no gerúndio, como se estivesse apenas completando a pergunta feita. Uma pergunta cuja resposta simples e rápida não exige a elaboração em forma de sentença; apenas um complemento, uma frase. Isto é, a prontidão da resposta produz o efeito de a pergunta ser óbvia, ou melhor, de ser uma pergunta que suscita uma resposta óbvia. Mas o que significaria "facilitar a vida" para o sujeito? Se buscarmos a resposta na formulação sobre "vantagem", teremos que "facilitar" significa "unificar o ensino da língua" inglesa, com a certeza de que os conteúdos serão todos ensinados e nada se perderá.

Vemos que esse significado de "facilitar a vida" pode ser relacionado à parte b de nossa categoria de análise, ou à possibilidade de se abrir "todo um campo de respostas, reações, efeitos, invenções”. Ou seja, o LDI representado no dizer de P1Q1 possibilitará a abertura desse campo de ações, ou produções; pois, ao facilitar a vida, tanto do professor como do aluno, o LDI abrirá outras vias de trabalho, de ação, que, mesmo facilitadas, serão 
outras. Porém, tal abertura desenha-se nesse dizer como algo que deverá ser controlado, pois será unificado, ou seja, homogeneizado pelo LDI. Sendo assim, ao mesmo tempo em que o LDI trará novas possibilidades de ação, terá sobre elas o controle homogeneizante e facilitador.

Adotando o estilo prático e objetivo da escrita em itens, o sujeito aponta uma desvantagem e opina sobre como o professor deve buscar outros recursos, além do LDI, para suas aulas, mas teme que isso não acontecerá. A busca por outros recursos parece garantir nesse dizer a condição de o professor se manter como uma pessoa que age. Porém, P1Q1 não diz que o professor não deverá "ficar somente preso a um único livro". Ao contrário, o uso do verbo "deveria" no futuro do pretérito, e não no futuro do presente, "deverá", parece indicar a reprovação de uma atitude já ocorrida ou em andamento mesmo antes da chegada do LDI do PNLD 2011.

(Con)fundindo passado, presente e futuro, o sujeito, como se adivinhando o que já acontece em algum lugar, reprova a situação em que o professor não se utiliza de outros materiais para planejar sua aula, marca o lugar de sua opinião e, portanto, se exclui do grupo dos professores presos ao "único livro", dizendo: "o professor, na minha opinião, não deveria ficar somente preso a um único livro". Por isso, há, para o sujeito, essa desvantagem, esse medo de que o LDI possa fazer com que o professor fique um pouco acomodado e não utilize outros recursos.

Também, a forma verbal "ficasse" não está em harmonia com os demais tempos da formulação. A forma subjuntiva não parece estar questionando a adoção do LDI, uma vez que isso já era certo em 2010, quando o questionário foi respondido. Esse tempo verbal, então, sugere uma posição hipotética e mais segura para o sujeito, talvez menos crítica, suavizando a repreensão anterior. Essa crítica suavizada ("talvez ficasse") acaba mantendo a possibilidade de o professor ser ainda representado como uma pessoa que age; pois, é possível que ele não fique acomodado. Além disso, o discurso sobre o LDI que será adotado permanece considerando a possibilidade de se abrir "todo um campo de respostas, reações, efeitos, invenções". Portanto, vemos que ambas as condições (a e b), necessárias para a articulação de uma relação de poder, são percebidas nos efeitos de sentido dos dizeres de P1Q1. Mesmo assim, devemos ainda observar com mais vagar como se forma a representação imaginária do LDI nos dizeres de P1Q1, para que, então, possamos tecer outras considerações.

A confusão de tempos verbais não ocorre apenas nessa formulação sobre a desvantagem nos dizeres desse sujeito. Também na formulação sobre a vantagem da adoção 
do LDI, percebemos o efeito de tempos se sobrepondo, como se o sujeito se perdesse no tempo. Sublinhamos abaixo:

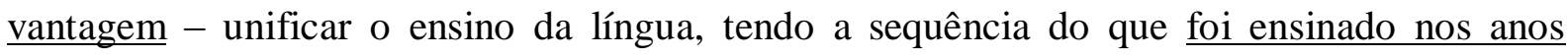
$\underline{\text { seguintes }}$

Novamente, então, o passado - "o que foi ensinado" - se aproxima e se confunde com o futuro - "nos anos seguintes". Há, aqui, a possibilidade de pelo menos três interpretações:

1. $[\ldots]$ tendo, nos anos seguintes, a sequência do que foi ensinado (anteriormente) ou [...] tendo a sequência dos conteúdos nos anos seguintes

2. [...] tendo a sequência do que foi ensinado nos anos anteriores [anteriores substitui "seguintes", sem o efeito de equívoco que pode ser produzido por "seguintes"]

3. [...] tendo a sequência do que será ensinado nos anos seguintes

A primeira possibilidade exigiria o deslocamento da locução adverbial de tempo ou a substituição de "o que foi ensinado" por "conteúdos", para que, assim, houvesse a desambiguização. Lembramos, aqui, sobre como essa formulação pode gerar tantas diferentes interpretações para o interlocutor e, ao mesmo tempo, ser tão natural para o sujeito enunciador. Os dois esquecimentos, conceitos de Michel Pêcheux (PÊCHEUX, M. [1975] 2009), podem nos ajudar a compreender como isso ocorre. Com o esquecimento número um, no nível do interdiscurso ${ }^{254}$, o sujeito tem a ilusão de ser a origem de seu dizer. No intradiscurso, nível da enunciação, o sujeito é afetado pelo esquecimento número dois, que o ilude sobre a unicidade de sentido de seu dizer. Afetado pelos dois esquecimentos, o sujeito toma seu discurso como transparente. A transparência ilusória garante, para o sujeito, o sentido estabilizado e único. Contudo, para o analista do discurso, o sentido é efeito percebido pela interpretação (ORLANDI, E., 1999) e, portanto, os dizeres permitem diferentes interpretações e produzem efeitos diferentes, todos analisáveis.

Já a segunda possibilidade apontaria para um equívoco, exigindo a troca de "seguintes" por "anteriores". O equívoco surge em discurso como um escape incontrolável, como algo que vem de outro lugar e, por ser estranho, não se encaixa, marcando um degrau

\footnotetext{
${ }^{254}$ De acordo com os estudos de Michel Pêcheux (1975), o discurso se dá no cruzamento entre dois eixos: o intradiscurso (nível da enunciação: da materialidade linguística) e o interdiscurso (nível do enunciado: da história e da memória).
} 
no fio discursivo. Ou seja, no intradiscurso (eixo da enunciação), a materialidade linguística apresenta a ruptura causada pelo choque entre passado ("foi ensinado") e futuro ("nos anos seguintes"). Essa mesma ruptura remete a um lugar no interdiscurso (eixo dos enunciados), um lugar de história e memória que, neste caso, não pode ser facilmente reconhecido, nem analisado.

A terceira interpretação exige a troca de tempo verbal (foi/será), para acomodar a ideia de futuro da locução adverbial. De qualquer modo e independente do desejo do sujeito, a formulação concentra certa tensão de sentidos justamente nos termos que se referem a tempo: "nos anos seguintes" e "foi ensinado".

O que parece não se estabilizar nesses dizeres talvez seja que o LDI é, para P1Q1, ao mesmo tempo, algo novo, capaz de homogeneizar o ensino e facilitar a vida, e já tão familiar, ao ponto de P1Q1 listar objetivamente vantagens e desvantagens, criticando comportamentos de professores que se acomodam e não usam outro material a não ser o livro que, naquele momento, ainda nem fora adotado. Ainda não fora adotado, mas, de algum modo, sempre esteve lá, prendendo e acomodando professores. Portanto, a mistura de tempos verbais, confundindo passado e futuro, produz o efeito de que, para P1Q1, é certo que o LDI irá facilitar a vida, unificar o ensino e promover a ordem dos conteúdos a serem ensinados, mas não é certo que, com o LDI do PNLD, os professores não se acomodarão, como provavelmente já aconteceu em algum momento passado quando usaram um livro didático qualquer.

Para esse sujeito, o LDI é o que facilitará a vida do professor e também a vida do aluno. Nos dizeres de P1Q1, a formulação sugere que ambos têm uma só vida comum ("Facilitando a vida do professor e aluno") ou os mesmos tipos de problemas que serão solucionados pelo LDI. A representação de professor como uma pessoa que age se estende também ao aluno; pois, aquilo que será facilitado na vida do professor e do aluno serão suas ações, presentes ou futuras, em decorrência da abertura desse "campo de respostas, reações, efeitos e invenções". Portanto, além de facilitar o ensino e a aprendizagem do inglês, o LDI é também o que unificará o ensino da língua; isto é, fará com que a língua inglesa seja ensinada de um único modo e com a mesma sequência de conteúdos ("do que foi ensinado") por todo o país. Essas atribuições do LDI foram listadas por P1Q1 no item "vantagem".

Com todas essas facilidades proporcionadas pelo LDI, o sujeito teme que o professor se acomode, utilizando apenas o LDI e não pesquisando em outras fontes; essa seria então a desvantagem. Nesse momento, o LDI é representado como incompleto. Contudo, a desvantagem da incompletude não está diretamente ligada ao LDI propriamente dito, mas à 
reação do professor diante da adoção do LDI. Ou seja, o sujeito não declara que essa é uma desvantagem do LDI, nem sugere que o LDI deveria facilitar a vida do professor, mas não muito, para que o professor não se acomode. Simplesmente, e mudando o foco de seu dizer do LDI para o professor, o sujeito atribui ao professor a desvantagem: o problema de acomodação. O LDI, por sua vez, é representado imaginariamente como a solução para a homogeneização do ensino de inglês, como algo uno, sem falhas, mas que irá exigir a não acomodação, a atualização constante do professor.

Para P1Q1, portanto, parece certo que o LDI irá facilitar o ensino e a aprendizagem da língua estrangeira, unificar, padronizar, o ensino através da sequência dos conteúdos. P1Q1 teme, também, que, por percebê-lo assim tão facilitador, o professor poderá não buscar outros recursos. Parece-nos que o receio de P1Q1, a acomodação do professor diante do livro didático, é um efeito colateral previsto pelo PNLD, que, antecipadamente, instruiu as editoras a fornecerem sugestões de recursos que poderiam ser utilizados pelo professor para expandirem as aulas. Sobre isso, o Edital de Convocação, que orientou as editoras sobre a elaboração das coleções, incluiu as instruções para a produção do manual do professor que reproduzimos abaixo na íntegra.

\section{Manual do Professor ${ }^{255}$}

Na avaliação das coleções de Língua Estrangeira Moderna, será observado se o Manual do Professor:

- apresenta com clareza a sua fundamentação teórica, de modo a que fiquem explícitos os princípios subjacentes à proposta das coleções, tendo em vista: a) teoria de linguagem e língua; b) teoria de aprendizagem de línguas; c) papéis do aluno e do professor; d) tipos de atividades; e) papel da avaliação; f) como o livro se organiza e integra as habilidades trabalhadas; g) outras informações que se façam necessárias para melhor compreensão da fundamentação teórica e metodológica que orientou a produção da coleção;

- estimula o professor a continuar investindo em sua própria aprendizagem, ampliando os seus conhecimentos da e sobre a língua bem como sobre as múltiplas formas de desenvolver as suas atividades de ensino;

- apresenta insumo lingüístico e informações culturais que propiciem a expansão do conhecimento do professor acerca das culturas vinculadas à língua estrangeira e do desenvolvimento de sua própria competência lingüística, comunicativa e cultural;

\footnotetext{
${ }^{255}$ Vemos que esses dizeres do Edital sobre o manual do professor corroboram nossas três categorias de análise. Porém, a análise detalhada de cada um desses itens demandaria uma extensão da nossa escrita incompatível à dimensão desta tese que já se prolonga.
} 
- propõe atividades extras variadas, que contemplem o desenvolvimento das quatro habilidades e das demais questões importantes vinculadas ao ensino de Língua Estrangeira (léxico, cultura, produção literária etc.), além das indicadas no livro do aluno;

- menciona materiais autênticos, de diferentes suportes midiáticos, que possam ser complementares aos materiais explorados na coleção didática;

- apresenta referências bibliográficas de qualidade, que orientem o professor em relação a leituras complementares, tanto sobre os temas que deve abordar em suas aulas quanto sobre questões relativas ao processo de aprendizagem e às metodologias de ensino;

- apresenta sugestões de implementação das atividades, porém evitando detalhamentos que possam impedir a criatividade e autonomia do professor;

- oferece sugestões de respostas para as atividades propostas no livro do aluno, sem, no entanto, restringi-las a uma única possibilidade, sobretudo tendo em conta a diversidade lingüística e cultural, que pode dar margem a diferentes soluções, e orientando o professor nesse sentido. [sic]

Já nas instruções para a elaboração das coleções, portanto, o discurso que fala sobre o livro didático - e, aqui, especificamente sobre o Manual do Professor - procura garantir meios para o professor não se acomodar e para usar outros materiais. Não podemos deixar de observar, contudo, que o oferecimento de sugestões e informações adicionais aponta ao desejo de completude (ilusória) e reforça a representação de acomodação do professor. Isso porque, ao buscar satisfazer esse desejo, o manual oferece sugestões e informações, demarcando o que pode e deve ser usado para a complementação das aulas, prendendo o professor ainda mais àquele material que tudo tem e tudo pode, mas que funciona por modulação, pois são sugestões que poderão ou não ser seguidas.

Portanto, o oferecimento de meios para o professor não se acomodar age no discurso sobre o LDI como a motivação para a ação contínua e atualizada do professor, ao mesmo tempo em que garante o controle dessas ações. Ou seja, tal oferecimento já direciona a ação do professor, pontuando aquilo que deve ser adicionado, pesquisado, elaborado, acessado etc. e determinando onde e como deve ser feito. Além disso, ao determinar o que deve ser explorado e expandido, delimita, como já dissemos, aquilo que fica de fora dessa ação e que não deve ou não precisa ser investigado ou desenvolvido.

De todo o modo, acreditamos poder afirmar que os dizeres que apontam à necessidade de não acomodação do professor, tanto nos dizeres de P1Q1 como no excerto do discurso 
oficial reproduzido acima, funcionam como princípios moduladores que tentam garantir a motivação pela incessante atualização. Como aquilo que caracteriza o funcionamento da sociedade de controle, a modulação garante o controle permanente, agindo sobre os modos de motivar o sujeito à atualização interminável. Ao mesmo tempo, o controle permanente, como um modo de funcionamento do poder, é exercido sobre uma pessoa que age e que é constantemente motivada a agir, atualizando-se; pois, a todo o momento, diante dessa relação de poder, há a possibilidade de se abrir "todo um campo de respostas, reações, efeitos, invenções" e linhas de fuga.

Vejamos agora a resposta de P9Q1 à mesma quarta pergunta do primeiro questionário.

S52 - P9Q1

O livro didático poderá contribuir para o ensino se ele se adequar as propostas teóricas recentes, em particular, aos PCN-LE no âmbito da leitura. Mas antes de tudo, a formação do professor de língua estrangeira no que tange a concepção de ensino de linguagem será fundamental para esse trabalho com livro, tendo em vista, que muitos professores de rede pública não são da área de inglês, muitos ministram a disciplina como complemento de aulas, para esses professores tudo que vier serve e o ensino continuará o mesmo de sempre. Na verdade, o acompanhamento pedagógico junto ao professor o ajudaria no trabalho com o livro, já que muitos docentes vêem a disciplina de inglês como desnecessária no currículo, isso é uma realidade a crença é a de que português e matemática são as disciplinas mais importantes e o inglês qualquer coisa serve, para esse professor seria uma desvantagem ele seguiria o livro sem uma visão crítica de ensino de língua estrangeira.

Nessa sequência discursiva, P9Q1 parece colocar o professor, e não o LDI, no centro de seu dizer em resposta à pergunta sobre as contribuições, vantagens e desvantagens do LDI para o ensino de inglês na escola pública. Portanto, já em relação ao primeiro elemento para a articulação de uma relação de poder, vemos que o professor, considerado neste estudo como uma pessoa que age, é representado no discurso de P9Q1 de três modos distintos. Isto é, há pelo menos três representações distintas de professor que são construídas nesses dizeres de P9Q1 juntamente com a representação de ensino de inglês.

Uma delas é a representação de professor de inglês da rede pública que não pertence à área de inglês e que leciona "a disciplina como complemento de aulas". Para P9Q1, esse professor que não é habilitado em inglês e que ministra aulas de inglês para complementar sua carga horária "tudo que vier serve e o ensino continuará o mesmo de sempre". Ou seja, esse professor que não é habilitado em inglês receberá qualquer material de bom grado, sem críticas, e, por isso, o ensino "continuará o mesmo". "Continuará o mesmo" parece acomodar a crítica de P9Q1 sobre o estado do ensino de inglês na escola pública naquele momento: 
ministrado por professores de outras áreas que aceitam qualquer tipo de material didático, sem críticas. A crítica feita por P9Q1 parece exigir, para esse professor representado como não habilitado, a formação de "professor de língua estrangeira no que tange a concepção de ensino de linguagem" e o "acompanhamento pedagógico" para trabalhar com o livro didático do PNLD 2011. O cumprimento dessas exigências resultaria, portanto, na habilitação e na capacitação do professor de língua inglesa e consequentemente na descontinuidade do ensino que esse professor não habilitado pratica, pois esse ensino não "continuará o mesmo de sempre".

A segunda representação surge no discurso de P9Q1 como um relato, ou até um desabafo, e trata do professor de outras disciplinas. Essa segunda representação é construída entre vírgulas num espaço do dizer que separa a justificativa de P9Q1 sobre a necessidade do "acompanhamento pedagógico" para o professor da primeira representação e a desvantagem do LDI para esse mesmo professor, como vemos no esquema abaixo em que separamos os segmentos do dizer e grifamos os termos que se referem ao professor.

$1^{\text {a }}$ representação de professor $\} \begin{aligned} & \text { Na verdade, o acompanhamento pedagógico } \\ & \text { junto ao professor o ajudaria no trabalho com o } \\ & \text { livro, }\end{aligned}$ $2^{\mathrm{a}}$ representação de professor $\}$ já que muitos docentes vêem a disciplina de inglês como desnecessária no currículo, isso é uma realidade a crença é a de que português e matemática são as disciplinas mais importantes e o inglês qualquer coisa serve,

$1^{\mathrm{a}}$ representação de professor $\}$ para esse professor seria uma desvantagem ele seguiria o livro sem uma visão crítica de ensino de língua estrangeira.

Essa divisão dos dizeres nos auxilia a interpretar o referente da última parte: "para esse professor". Isto é, vemos que "para esse professor" não se refere a "muitos docentes" do segmento anterior, pois, além de estar no singular, o professor em "para esse professor" ensina a "língua estrangeira" e o professor em "muitos docentes", por ver "a disciplina de 
inglês como desnecessária no currículo", não seria um professor de inglês. Portanto, o segmento iniciado por "para esse professor" completa a primeira representação de professor, caracterizando-o como aquele que aceitaria o LDI como um saber completo, sem se posicionar criticamente em relação ao ensino de língua inglesa.

A segunda representação de professor, portanto, trata do professor de outras disciplinas que considera a matemática e o português como as "disciplinas mais importantes" no currículo e a "disciplina de inglês como desnecessária", para a qual "qualquer coisa serve". Esse professor de outras disciplinas considera, então, o ensino de inglês como secundário, desnecessário e, por isso, o material para o ensino de inglês é irrelevante.

A terceira representação só pode ser percebida em seu próprio apagamento nos dizeres de P9Q1. Isto é, sendo P9Q1 também um professor da rede pública de ensino, seus dizeres sobre os outros professores (os não habilitados e os de outras disciplinas) marcam aquilo que P9Q1 não é, definindo, assim, sua própria identidade construída a partir das diferenças entre sua autorrepresentação e as representações dos outros professores. Ao distanciar-se das representações dos outros professores, P9Q1 parece se autorrepresentar, portanto, como um professor habilitado, da "área de inglês", que não ministra a "disciplina como complemento de aulas" e considera o ensino de inglês como necessário e importante. Em relação ao livro didático, P9Q1, sustentando essa terceira representação de professor, não se contenta com qualquer material e acredita em sua contribuição para o ensino, com a condição de o LDI "se adequar as propostas teóricas recentes, em particular, aos PCN-LE no âmbito da leitura". Assim, o LDI não será uma desvantagem para esse professor da terceira representação, pois ele não "seguiria o livro sem uma visão crítica de ensino de língua estrangeira".

É essa terceira representação de professor que, nos dizeres de P9Q1, parece funcionar como o primeiro elemento necessário para a articulação de uma relação de poder. Isso porque, o professor como uma pessoa que age não encontra apoio na primeira representação por se tratar de um professor não habilitado em inglês que é, assim, indiferente aos materiais que utiliza. A segunda representação trata do professor de outras disciplinas que é também indiferente ao ensino de inglês. O professor como uma pessoa que age só pode ser percebido na terceira representação; pois, é aí que o professor de inglês é representado como não sendo indiferente aos materiais, mas que exige a adequação do LDI às "propostas teóricas recentes" e acredita na importância da disciplina de inglês e na contribuição dos materiais ao ensino de língua estrangeira.

Vemos emergir também nesse discurso sobre o LDI o segundo elemento indispensável para a articulação de uma relação de poder. Isso porque, é essa terceira representação de 
professor, como uma pessoa que age, que não aceita "tudo que vier", que não se satisfaz com "qualquer coisa" e que acredita que, através do uso do LDI, o ensino não "continuará o mesmo de sempre". O LDI não é, portanto, representado como uma desvantagem para esse professor. Ao contrário, o LDI seria uma vantagem, pois esse professor, para P9Q1, tem "uma visão crítica de ensino de língua estrangeira" e não "seguiria o livro". Com essa postura de insatisfação e de reconhecimento da incompletude em relação ao LDI, abre-se "todo um campo de respostas, reações, efeitos e invenções" propício à mudança e que está, ao mesmo tempo, envolto em relações de poder. Isso porque, é de dentro dessas relações que as mudanças ocorrem, visto que não há lugar que não esteja já marcado por relações de poder, pois, como argumentou Foucault ([1982] 1995 p. 246): “Uma sociedade 'sem relações de poder' só pode ser uma abstração".

A essa terceira categoria de análise, correspondemos também a quarta pergunta do segundo questionário. Essa pergunta foi redigida a partir da quarta pergunta do primeiro questionário e apenas atualizada para o momento do segundo questionário, após a adoção do LDI.

4) Em sua opinião, de que modo o livro didático está (ou não) contribuindo para o ensino de inglês como língua estrangeira na escola pública? Quais são as vantagens e/ou desvantagens dessa adoção?

A resposta de $\mathrm{P} 8 \mathrm{Q} 2$ lê:

S53 - P8Q2

O livro contribui como uma rota a seguir, a desvantagem é que tem professor que se guia ou se prende a unicamente ao livro, deixando de buscar novas idéias.

Assim como P1Q1, P8Q2 também atribui a desvantagem do LDI ao professor. Isto é, ao falarem sobre as desvantagens do LDI, tanto P1Q1 como P8Q2 mudam o foco do dizer: do livro para o professor. O LDI parece ser, então, representado como completo, já que só apresenta vantagens. Nos dizeres de P8Q2, vemos que o professor ideal é discursivisado como aquele que busca novas ideias e não "se guia ou se prende" unicamente ao LDI. Portanto, observamos que o primeiro elemento da articulação de uma relação de poder, o professor como uma pessoa que age, pode ser percebido nos dizeres de P8Q2 como um professor ideal ou, ainda, como um ideal a ser perseguido. 
Nesses dizeres, a busca por novas ideias, como defende P8Q2, produzem o efeito de que, ao fazê-lo, o professor ideal estaria, de certo modo, se afastando da "rota" oferecida pelo livro e, assim, não se guiaria ou prenderia unicamente ao LDI. A possibilidade de afastamento da rota parece sugerir, então, a possibilidade de se abrir "todo um campo de respostas, reações, efeitos e invenções". Além disso, ao apoiarem a busca por novas ideias, os dizeres de P8Q2, assim como os dizeres de P1Q1, sugerem a necessidade de o professor inserir-se no processo de uma atualização interminável, como é característico do funcionamento das sociedades de controle.

À mesma pergunta quatro do segundo questionário, P9Q2 responde:

S54 - P9Q2

O livro ajuda, porém foge muito da grade curricular e quando vamos trabalhar outras coisas os alunos reclamam que trazem os livros e eles não são quase usados.

Para P9Q2, mesmo sem conter todos os conteúdos previstos na grade curricular, o LDI do PNLD “ajuda”. Nesse dizer, o verbo ajudar está sendo usado como intransitivo e, portanto, não é possível determinar quem ou o que estaria sendo ajudado. Essa indeterminação do objeto gramatical de ajudar parece compor a construção de uma denegação nesse dizer. Se admitirmos que um livro didático pode ajudar, digamos, o professor, o aluno, a aula e o ensino, vemos que os dizeres de P9Q2 negam essa ajuda do LDI a todos. Isto é, ao afirmar que o LDI "foge muito da grade curricular", P9Q2 nega a contribuição do LDI ao ensino de inglês na escola pública justamente por ele não contemplar os conteúdos obrigatórios para esse ensino. Ainda por não apresentar os conteúdos com os quais o professor precisa trabalhar, o LDI não ajuda o professor, que tem de "trabalhar outras coisas" e, portanto, buscá-las em outro lugar, em outros materiais, prepará-las etc. Para P9Q2, o LDI também não ajuda os alunos porque eles "reclamam", têm de trazê-lo para a escola e levá-los de volta, sem usá-lo; pois, P9Q2 informa que "os alunos reclamam que trazem os livros e eles não são quase usados". Se "eles não são quase usados" na aula, é porque eles (o LDI) não ajudam a aula, que deve então ter como suporte algum outro material, que, neste caso, corresponde às "outras coisas" com as quais P9Q2 trabalha. Portanto, no dizer de P9Q2, se o LDI não ajuda o professor, o aluno, a aula nem o ensino, a afirmação "O livro ajuda" funciona como uma denegação: o livro não ajuda. Em outros termos, a afirmação "O livro ajuda" não apenas não encontra apoio nos dizeres que lhe são posteriores, mas também é refutada por eles. 
Em relação ao primeiro elemento necessário para a articulação da relação de poder, vemos que o professor é mantido nesses dizeres de P9Q2 como uma pessoa que age, pois, ao perceber onde o LDI falta, P9Q2 trabalha "outras coisas". Sobre o segundo elemento da articulação, podemos perceber que é exatamente na falta do LDI que surge a possibilidade de se abrir "todo um campo de respostas, reações, efeitos e invenções". Talvez as respostas de P9Q2 a essa falta do LDI não tenham conseguido evitar as reclamações dos alunos. Mas, na condição de ser uma pessoa que age e com a abertura do "campo de respostas, reações, efeitos e invenções", outras possibilidades poderão ainda surgir para P9Q2.

Analisamos, a seguir, os dizeres do discurso da mídia.

\subsection{Dizeres do discurso midiático}

Procuramos observar a articulação da relação de saber-poder, para perceber se é possível caracterizar o discurso sobre o LDI como um investimento de poder que torna o LDI um discurso de verdade e como isso ocorre no discurso. Novamente, nos concentraremos em perceber se e como, no discurso sobre o LDI, o poder é exercido sobre uma pessoa que age e se há a possibilidade de se abrir "todo um campo de respostas, reações, efeitos e invenções".

A sequência discursiva abaixo faz parte da reportagem publicada pela agência de notícias 45 graus $^{256}$ de Teresina, Piauí, no dia 21 de junho de 2010.

S55 - 21 jun. 2010

\section{Escolas escolhem livro didático para 2011}

$[\ldots]$

A supervisora do livro didática ${ }^{257}$ da Secretaria Estadual da Educação e Cultura (Seduc), Joana Batista, explica que no caso do livro de língua estrangeira é a escola que vai optar pelo inglês ou espanhol. "Tanto o livro de língua estrangeira como os outros livros devem ser escolhido levando em consideração a proposta pedagógica de cada escola. O Ministério da Educação disponibiliza em seu site um Guia do Programa Nacional do Livro Didático com o resumo das obras que foram selecionadas pela Secretaria de Educação Básica do Mec e os professores devem acessar esse Guia para saber qual obra melhor se adequa a proposta de sua escola", explicou.

O dia em que a reportagem foi disponibilizada na internet marcou o início do período de escolha das coleções pelos professores. O prazo para o registro das coleções didáticas escolhidas observou o período de 21 de junho a 04 de julho de 2010. Lembramos que a Carta

\footnotetext{
${ }^{256}$ Cf. <http://www.45graus.com.br/escolas-escolhem-livro-didatico-para- 2011,geral,64625.html >. Acesso em 10 mar. 2011.

${ }^{257}$ Conforme a redação do texto original.
} 
Circular n. ${ }^{0}$ 04/2010 já informara sobre a necessidade de a escola indicar duas coleções por componente curricular em abril e que o Guia de Livros Didáticos, com as resenhas e outras informações específicas sobre as duas únicas coleções aprovadas, foi divulgado no site do MEC em 29 de abril de 2010. Portanto, estamos novamente diante de dizeres que insistem na necessidade de se escolher duas coleções dentre as duas existentes. Vejamos os dizeres do excerto acima que selecionamos para a análise.

\section{S55a}

A supervisora do livro didática da Secretaria Estadual da Educação e Cultura (Seduc), Joana Batista, explica que no caso do livro de língua estrangeira é a escola que vai optar pelo inglês ou espanhol.

Iniciando o parágrafo da reportagem, esses dizeres informam o leitor, em discurso relatado indireto, sobre a explicação da supervisora do livro didático: "é a escola que vai optar pelo inglês ou espanhol". Aqui, as disciplinas de língua estrangeira se confundem com seus respectivos livros didáticos. Isto é, mesmo antes da adoção, cada escola já oferecia em sua grade curricular as disciplinas de inglês e/ou espanhol. Portanto, espera-se que a escola que já oferece a disciplina de inglês opte pelas coleções de inglês, enquanto a escola que oferece a disciplina de espanhol requisite as coleções de espanhol. Há casos em que ambas as disciplinas são oferecidas; portanto, todas as coleções devem ser requisitadas. $\mathrm{Na}$ falta dessa informação, o dizer acima produz o sentido de que é nesse momento da chegada do livro didático de língua estrangeira que a escola vai fazer sua opção pela língua que ensinará. Além disso, esse dizer produz também o sentido de que a escola é livre para escolher a língua estrangeira com a qual quer trabalhar. No entanto, essa escolha já está também prédeterminada pela disciplina que foi anteriormente incluída na grade curricular da escola e que já participa da vida daquela escola.

$\mathrm{S} 55 \mathrm{~b}$

"Tanto o livro de língua estrangeira como os outros livros devem ser escolhido levando em consideração a proposta pedagógica de cada escola. [...]

Agora em discurso direto, a reportagem reproduz o dizer da supervisora. A escrita desse dizer parece sugerir, pela falta de pontuação, de concordância etc., que podem não ter sido essas as palavras exatas da supervisora do MEC. Sendo assim, ao reproduzir os dizeres do discurso oficial como uma citação, entre aspas, modificando mesmo que minimamente sua 
escrita, o discurso midiático acaba marcando a materialidade discursiva com traços representativos de autoria, ou de coautoria dessa citação e se responsabilizando por ela.

Portanto, acreditamos que os dizeres de sujeitos do discurso oficial disponibilizados pela mídia como citações podem também ser considerados para a análise do discurso midiático. Além disso, como afirma Authier-Revuz ([1998] 2001, p. 145-6), o discurso direto ou indireto não relata uma frase, mas um ato de enunciação, isto é, "um acontecimento particular", com seu próprio tempo e lugar. Entendemos, portanto, que o discurso relatado (direto ou indireto) não é a simples reprodução do dizer do sujeito devido às diferentes condições de produção envolvidas em cada ato de enunciação. Authier-Revuz ([1998] 2001, p. 149) argumenta ainda:

Há em DD uma ficção de apagamento, uma ostentação de objetividade no "eu cito" (com valor de eu não intervenho) no momento mesmo em que o enunciador L "puxa a linha" da interpretação de $\mathbf{m}^{258}$ pela descrição que ele dá de e; esta será sempre, inevitavelmente, parcial e subjetiva.

Desse modo, ao reproduzir o discurso oficial, o discurso midiático o interpreta subjetivamente, colocando algo de si no discurso do outro. Nos dizeres do excerto que agora analisamos, esse algo de si se projeta na escrita faltosa do texto atribuído à autoria da supervisora, marcando a heterogeneidade enunciativa do dizer na materialidade discursiva. Mesmo assim, esses traços de coautoria, como mencionamos, não chegam a estabelecer algum tipo de posicionamento crítico da mídia em relação à notícia, veiculada apenas como um informe.

Prosseguindo com a análise dos dizeres dessa sequência discursiva, vemos que a escolha do LDI deve estar relacionada à proposta pedagógica da escola que o adotará. Conclui-se, então, que as coleções oferecem essa possibilidade de poderem ser relacionadas à proposta pedagógica da escola. Sabemos que, segundo o discurso oficial, na falta da coleção escolhida como primeira opção, a outra coleção, isto é, a segunda opção, será enviada às escolas. Pressupõe-se, então, que ambas as coleções apresentem a mesma proposta pedagógica, pois isso explicaria a ênfase do MEC/FNDE sobre a possibilidade de substituição da segunda opção pela primeira.

Uma vez que o livro que a escola venha a escolher deve estar em concordância com a proposta pedagógica dessa escola, pressupõe-se, também, que a proposta da escola seja a

${ }^{258}$ Cf. AUTHIER-REVUZ, J., [1998] 2001, p. 140, m corresponde ao sintagma introdutor do discurso relatado que "descreve um ato de enunciação como tendo efetivamente acontecido anteriormente (ele disse...; ele diz frequentemente)". A autora (IBID. p. 146) define e como o objeto da mensagem do DR. 
mesma de ambas as coleções. Portanto, espera-se que todas as escolas brasileiras que utilizarão o LDI do PNLD 2011 tenham a mesma proposta apresentada nas coleções. Concluise, então, que deve haver a correspondência entre a proposta das duas coleções e as propostas de todas as escolas brasileiras. Isto é, fica pressuposta a existência de uma única proposta pedagógica sendo trabalhada em todo o território nacional e que corresponde, também, à proposta de ambas as coleções aprovadas para o PNLD 2011.

Contudo, essa ilusão de homogeneidade pedagógica no ensino de inglês em âmbito nacional, gerada pela obrigatoriedade dessa correspondência, não observa as diferenças que o discurso oficial, na dispersão dos enunciados, parece apoiar. Vejamos alguns dizeres do discurso oficial sobre a necessidade de as diferenças serem observadas. Os seguintes dizeres pertencem ao Edital de Convocação:

- De acordo com a Constituição Federal, o ensino escolar será ministrado tendo como base: (a) igualdade de condições para o acesso e a permanência na escola; (b) liberdade de aprender e ensinar; (c) pluralismo de idéias e de concepções pedagógicas; (d) gratuidade do ensino público; (e) gestão democrática; e (f) garantia de um padrão de qualidade.

- Como parte integrante de suas propostas pedagógicas, as coleções devem contribuir efetivamente para a construção da cidadania. Nessa perspectiva, as obras didáticas devem representar a sociedade na qual se inserem, procurando:

$[\ldots]$

- incentivar a ação pedagógica voltada para o respeito e valorização da diversidade, aos conceitos de sustentabilidade e da cidadania ativa, apoiando práticas pedagógicas democráticas e o exercício do respeito e da tolerância;

Vemos, portanto, que os dizeres que promovem a valorização da diferença não encontram apoio nas práticas efetivadas. Ou seja, não se pode esperar que duas coleções que tenham, possivelmente, a mesma concepção pedagógica, já que uma pode substituir a outra, estariam respeitando o pluralismo de ideias e de concepções pedagógicas. Do mesmo modo, não se pode desejar que todas as escolas públicas brasileiras sigam a mesma orientação pedagógica e ainda exigir o "respeito e a valorização da diversidade". Além disso, considerando a diversidade cultural, social, educacional, econômica, linguística etc. em nosso país, não se pode esperar que as duas coleções com a mesma concepção pedagógica consigam "representar a sociedade na qual se inserem"; pois, haveríamos de nos perguntar qual sociedade estaria ali sendo representada.

A última sequência discursiva retirada do excerto diz: 
$\mathrm{S} 55 \mathrm{c}$

O Ministério da Educação disponibiliza em seu site um Guia do Programa Nacional do Livro Didático com o resumo das obras que foram selecionadas pela Secretaria de Educação Básica do Mec e os professores devem acessar esse Guia para saber qual obra melhor se adequa a proposta de sua escola", explicou.

Esse dizer informa como os professores podem ter acesso às propostas pedagógicas das coleções e, assim, escolher aquela que mais se adéqua à proposta de sua escola. Porém, como vimos, não há escolha a ser feita; ambas as coleções indicadas devem ser selecionadas pelo professor. Além disso, com base nos dizeres do Quadro Comparativo que analisamos, é pouco provável que o professor escolhesse, como primeira opção, a coleção que apresenta seis tons claros e um tom intermediário. Mesmo assim, em S55c, o professor é ainda mantido como uma pessoa que age; pois deve acessar o Guia, verificar a coleção mais adequada à proposta de sua escola e, por fim, fazer a "escolha". Do mesmo modo, na ilusão da transparência discursiva, fica mantida a "liberdade" de ação do professor; pois, o dizer da sequência observa a possibilidade de respostas e resultados, como se estes já não tivessem sido determinados.

\section{Considerações sobre o capítulo}

A análise dos dizeres reservados a este capítulo procurou observar como se dá a articulação entre poder e saber no discurso sobre o livro didático de inglês. Para isso, subdividimos nossa terceira categoria de análise, a articulação entre poder e saber, em dois itens: a) o poder é exercido sobre uma pessoa que age e b) diante de uma relação de poder, há a possibilidade de se abrir "todo um campo de respostas, reações, efeitos e invenções". A observação desses dois itens se fez necessária uma vez que Foucault (FOUCAULT, M., 1982, p. 220) os estabelece como elementos indispensáveis para se ter uma relação de poder.

Ao analisarmos os dizeres do discurso oficial, observamos que as ações atribuídas aos órgãos responsáveis pelo programa de adoção do LDI incidem sobre as ações do professor. Essa observação nos permitiu relacionar esse efeito à noção foucaultiana de poder, definido como um modo de ação sobre outras ações. Mesmo que essas ações do professor já estivessem de algum modo pré-determinadas pelas ações dos órgãos governamentais, o professor foi representado como uma pessoa que age e foi percebida a possibilidade de se ter "todo um campo de respostas, reações, efeitos e invenções", como sugere Foucault ${ }^{259}$. Observamos, portanto, que houve o investimento de poder no LDI, para que ele funcione

${ }^{259}$ FOUCAULT, M., [1982] 1995, p. 243. 
como um discurso de verdade. Em S50, os dizeres sobre a função que o PNLD cumpre produzem o efeito de estar modalizando uma medida de ordem soberana, um açambarcamento modalizado, cujo objetivo final é a "escolha" e o uso do LDI na escola pública brasileira.

Também com a análise do discurso profissional, pudemos perceber a mesma articulação da relação saber-poder; isto é, o professor sendo mantido até o fim como uma pessoa que age e a possibilidade de haver a abertura de "todo um campo de respostas e reações”. Através da análise, foi possível perceber que os dizeres sobre a necessidade de o professor estar sempre se atualizando e não se acomodar podem estar funcionando no discurso sobre o LDI como um princípio modulador, característico da sociedade de controle (DELEUZE, G., [1990] 2008), garantindo a motivação pela atualização constante.

A análise dos dizeres do discurso midiático nos possibilitou, novamente, a percepção da construção da representação de "escolha". Nos dizeres que analisamos do discurso sobre o LDI, a "escolha" não existe como prática não discursiva. Essa "escolha" parece apenas existir como prática discursiva e é representada no discurso como o lugar de ação do professor. A "escolha", portanto, garante que o professor seja mantido até o fim como uma pessoa que age, pois é ele quem escolherá o LDI, e garante, também discursivamente, a possibilidade de se abrir "todo um campo de respostas, reações, efeitos, invenções" (FOUCAULT, M., [1982] 1995, p. 243). 


\section{CONCLUSÃO}

A análise dos dizeres dos discursos oficial, profissional e midiático que empreendemos neste estudo parece corroborar nossa hipótese de que o LDI funciona como verdade por ser representado como tal pelo discurso que fala sobre ele. Muitas vezes a representação do LDI como verdade é construída nesses dizeres a partir do livro fechado. Ou seja, não é preciso conhecer o que há nas páginas do LDI para já considerá-lo como um saber, uma verdade. Vimos que tal representação pode se referir tanto a um LDI ideal e imaginário ou ao LDI do PNLD 2011. Em outros termos, talvez possamos dizer que, nesses casos, a representação do LDI como verdade funciona como um pressuposto e, portanto, prescinde do discurso do LDI, que já é desde sempre tomado como verdade. Tal concepção de LDI considera, portanto $a$ priori, que aquilo que ele possa apresentar internamente, isto é, o discurso do LDI, se encontra legitimado como saberes/verdades que podem circular na sociedade. Há aí um grande investimento de poder no LDI que o faz funcionar como uma verdade inquestionável.

Por outro lado, percebemos que, para que essa representação do LDI como verdade funcione naturalizada e pressuposta, há a elaboração cuidadosa dos dizeres do discurso oficial sobre o LDI, trabalhando no sentido de garantir tanto o efeito de verdade do discurso do LDI em seus dizeres (dizeres do discurso oficial) como a propagação desse efeito para outros discursos. Como vimos, mesmo o cuidado na elaboração dos dizeres do discurso oficial não conteve, na dispersão do discurso, o sentido de que a escolha fosse exclusivamente uma prática discursiva. Na dispersão do discurso, também, a isenção de erros passou da rejeição para a aceitação e essa passagem foi analisada como um efeito de modalização que suaviza o dizer e oferece alternativas, ou linhas de fuga.

A propagação dos dizeres do discurso oficial sobre o LDI, especialmente em relação ao efeito de verdade do discurso do LDI, foi analisada na ação de "copia e cola" percebida no discurso midiático. Isto é, o repasse do texto oficial, veiculado como notícia sem o posicionamento da mídia, reforça a representação do LDI como um discurso de verdade pela repetição que apenas aceita, garantindo a tranquilidade sobre a chegada do LDI na escola pública. Também no discurso profissional essa propagação encontrou respaldo. Como argumentamos anteriormente, nenhum respondente aos questionários de pesquisa se posicionou contra a proposta governamental para a adoção de um LDI. Além disso, mesmo que alguns respondentes tenham reivindicado a oferta de um número maior de coleções para fazerem sua escolha nos próximos programas, nenhum questionou os dizeres dos documentos oficiais do PNLD 2011 que exigiram a escolha de dois títulos de coleções didáticas dentre os 
dois oferecidos. Portanto, vemos que tanto o discurso midiático como o discurso profissional parecem pressupor o discurso do LDI do PNLD 20011 como verdade a partir da representação desse LDI propagada como verdade pelo discurso oficial. De todo o modo, a representação do LDI como verdade nos discursos midiático e profissional sobre o LDI, mesmo por repasse da representação construída no/pelo discurso oficial, reforça, pela repetição, o investimento de poder no discurso do LDI para que ele funcione como uma verdade.

Muitas vezes, principalmente nas respostas ao primeiro questionário, o LDI foi discursivisado como um objeto simbólico, isto é, carregado de valores historicamente construídos na sociedade. Naquele momento em que o LDI do PNLD 2011 ainda não era conhecido pelos professores-respondentes, pudemos observar a representação do LDI como um discurso de verdade e um importante objeto simbólico. Um objeto que viria legitimar a disciplina de inglês na escola pública (P1Q1, P4Q1, P5Q1, P9Q1 etc.), completar a formação do professor (P2Q1, P8Q1, P9Q1), promover o interesse e melhorar o entendimento dos alunos (P3Q1, P7Q1), ampliar os conteúdos e organizar o currículo (P7Q1, P8Q1). Outras vezes, especialmente nas respostas ao segundo questionário, o LDI foi representado como um objeto qualquer, como se fosse destituído de seu valor simbólico. Isto é, um objeto cuja presença material, física, é valorizada, mas que traz a verdade como um pressuposto, como discutimos acima. A partir dessa observação e com o apoio da perspectiva pecheutiana de que o caráter da ideologia é "de dissimular sua própria existência no interior mesmo do seu funcionamento" (PÊCHEUX, M., [1975] 2009, p. 139), é possível argumentar que estando a verdade do LDI pressuposta, o caráter simbólico do livro didático subjaz dissimulado em seu próprio funcionamento como um discurso de verdade. Portanto, mesmo quando discursivisado como um objeto dessimbolizado, um livro fechado, o livro didático de inglês é representado no discurso sobre o LDI, ao mesmo tempo, como um discurso de verdade pressuposto e um objeto simbólico dissimulado. Como discutimos, o efeito de dessimbolização parece agir pela denegação do valor simbólico do objeto de troca. O objeto torna-se atraente justamente pela denegação da carga de simbolização que historicamente o constitui.

No presente estudo, procuramos desenvolver um caminho em que pudéssemos observar o modo de funcionamento da verdade na sociedade atual. Para isso, inicialmente, tomamos os conceitos foucaultianos de verdade e poder, considerando também a articulação da relação entre eles, conforme pensada por Michel Foucault ([1982] 1995). 
Consideramos esses conceitos essenciais para compreendermos o funcionamento de uma sociedade; porém, cada sociedade imprime suas próprias características no modo como os colocam em funcionamento. Isto é, a verdade, que Foucault iguala a saber, é definida por ele como "um conjunto de procedimentos regulados para a produção, a lei, a repartição, a circulação e o funcionamento dos enunciados". Fica, então, a cargo de cada sociedade determinar quais procedimentos devem pertencer a tal conjunto e o modo como esse conjunto será regulado. Em relação ao poder, definido por Foucault como uma ação sobre outra ou um conjunto de ações sobre outras ações, cada sociedade determina quais ações (ou conjunto de ações) devem incidir sobre quais outras e, também, o modo como cada ação deve incidir sobre outra. Para definir a articulação da relação de poder, Foucault estabelece duas condições. A primeira, o poder é exercido sobre uma pessoa que age, requer que cada sociedade determine em cada caso quem é essa pessoa que age, quais são suas ações e o modo como o poder deve ser exercido. A segunda condição, diante de uma relação de poder, há a possibilidade de se abrir "todo um campo de respostas, reações, efeitos e invenções", reclama que cada sociedade considere os modos de abertura desse campo, mesmo sem conseguir determinar com precisão todas as respostas, reações, efeitos e invenções que daí possam surgir como consequências de uma relação de poder.

A partir dessa segunda condição estabelecida por Foucault, podemos pensar com mais propriedade sobre o conceito deleuziano de linha de fuga ${ }^{260}$, que caracteriza uma sociedade. Isso porque essas linhas de fuga não representam o escape total, uma vez que se remetem umas às outras e às linhas de segmentaridade, mas garantem a impossibilidade de dicotomias ao constituírem múltiplas alternativas, abrindo esse "campo de respostas, reações, efeitos e invenções".

Além disso, como analisamos na materialidade linguística, a modalização do dizer garante discursivamente o segundo elemento necessário para a articulação de uma relação de poder: a possibilidade de se abrir "todo um campo de respostas, reações, efeitos e invenções"261. Discutimos que a modalização do dizer produz efeitos de suavização, inconclusão, adiamento do fim e abre linhas de fuga e possibilidades de respostas, reações, efeitos e invenções.

Em outros termos, a análise do discurso sobre o livro didático de inglês que empreendemos percebeu o modo de funcionamento da sociedade de controle em ambos os eixos discursivos. No eixo do interdiscurso, percebemos os enunciados que funcionam como

\footnotetext{
${ }^{260}$ Cf. DELEUZE, G.; GUATTARI, F., [1980] 1995.

${ }^{261}$ Cf. FOUCAULT, M., [1982] 1995, p. 243.
} 
princípios moduladores, garantindo o adiamento do fim, demandando atualizações contínuas, motivando o indivíduo e assegurando o controle. No eixo do intradiscurso, percebemos que a materialidade linguística dos dizeres do corpus de pesquisa é frequentemente marcada pela modalização do dizer, como uma moldagem autodeformante, que parece produzir naturalmente o efeito de suscitar outros caminhos. Porém, o oferecimento de múltiplas possibilidades produzido discursivamente pela modalização contrasta com o dizer que trabalha para manter o sentido desejado. Como analisamos, o dizer "é conveniente" tanto remete ao sentido de ser aconselhável como de não ser obrigatório, ou ainda de ser opcional, necessário, desnecessário etc.

Vimos, também, que muitas das práticas discursivas que se constroem nos dizeres do discurso sobre o LDI (a escolha da coleção feita pelo professor, a distribuição de livros a todos os alunos, a condição de o livro ser consumível etc.) nem sempre encontram apoio e legitimação nas práticas não-discursivas.

Neste estudo, discutimos alguns aspectos diferenciais das sociedades de soberania, disciplinar e de controle. Através da análise do discurso sobre o LDI, vimos que sempre houve o controle sobre os enunciados que circulam na sociedade e que o livro didático é um meio de ação importante para esse controle na esfera educacional. Parece-nos que as sociedades de soberania, disciplinar e de controle têm diante de si os mesmos elementos sobre os quais exercem seu controle: os corpos, o tempo e o espaço. Em cada época, porém, os conceitos de corpo, tempo e espaço adquirem outros sentidos. O controle deve então se adaptar. Hoje, para o controle ter alguma eficácia, é preciso atingir o corpo no espaço aberto, globalizado, quase infinito num tempo cada vez mais rápido e fluido. $\mathrm{O}$ espaço aberto parece ser ao mesmo tempo lugar de liberdade e de controle. No espaço aberto, o sujeito e suas ações têm mais amplitude, se estendem quase infinitamente. Mas, ao mesmo tempo, é nesse espaço em que o sujeito se estende que ele se projeta e se mostra, se faz conhecido. Suas informações alimentam a construção do controle que agirá sobre suas ações com muito mais força, pois é individualizado, quase personalizado, como nos filtros de busca, nos mecanismos de interpretação dos sites e das redes sociais sobre as preferências dos usuários. Novos dispositivos de localização (como os GPS, radares, satélites etc.), de informação e comunicação (como o NFC, Near Field Communication, ou Comunicação de Campo Próximo, para troca de dados e conexões sem fio entre dois dispositivos) são desenvolvidos para ampliar a liberdade e aprimorar o controle. Assim, quanto mais livre se encontra o corpo no tempo e no espaço, maior o controle que sobre ele se exerce. Mesmo assim, e contrastando com a alta tecnologia cada vez mais aprimorada, eficaz e acessível, o livro didático de inglês 
em papel chega à escola pública brasileira. Parece-nos, portanto, que o LDI, através de sua adoção em âmbito nacional, veio contribuir incisivamente tanto para o controle das ações dos professores e dos alunos como dos enunciados que podem e devem circular em nossa sociedade.

$\mathrm{Na}$ análise, vimos que as representações de língua estrangeira, professor e aluno construídas no/pelo discurso sobre o LDI do PNLD 2011 remontam às mesmas concepções que têm historicamente valorizado o conteúdo e a forma em detrimento do processo de subjetivação no ensino e na aprendizagem de língua estrangeira. Desse modo, o PNLD 2011, na condição de ser a primeira adoção nacional do LDI, poderia ser considerado como um acontecimento histórico, mas que não produziu deslocamentos nos modos de definir e representar o ensino, o aprendizado, o aluno, o professor, a língua estrangeira etc. Por não ter produzido deslocamentos nas representações imaginárias, esse acontecimento histórico não poderia ser compreendido também como um acontecimento discursivo. Isso porque Michel Pêcheux ([1983] 2002, p. 17) define acontecimento como aquilo que se dá "no ponto de encontro de uma atualidade e uma memória", acrescentando que, num acontecimento discursivo, os "enunciados remetem [...] ao mesmo fato, mas eles não constroem as mesmas significações" (PÊCHEUX, M., [1983] 2002, p. 20). Ao remeter às mesmas representações tradicionais de livro didático, língua estrangeira, aluno e professor, o discurso sobre o LDI do PNLD 2011 não estaria construindo outras significações, mas apenas reescrevendo-as. Por outro lado, a reescritura dessas mesmas representações, como um retorno do já-dito, é produzida no intradiscurso sob a influência dos princípios moduladores, que, nesse eixo, funcionam pela modalização do dizer.

Como vimos, a modalização produz os efeitos de inconclusão, adiamento do término e abertura de linhas de fuga. Mais especificamente, a modalização percebida na enunciação, no intradiscurso, produz esses efeitos justamente por determinar no interdiscurso mais de uma possibilidade de significação. Nesse movimento, entram em jogo mais de uma formação discursiva, mais de uma formação ideológica, mais de uma formação imaginária; isto é, aquelas previstas e não previstas pelo sujeito enunciador. Essa parece ser, então, uma implicação da modalização do dizer no intradiscurso: gerar uma tensão que não permite a estabilização do sentido, mesmo que local e temporária, no interdiscurso.

Em outros termos, a modalização do dizer, funcionando no eixo do intradiscurso, provoca efeitos no interdiscurso, adiando a determinação do sentido, ou melhor, adiando o reconhecimento da região do interdiscurso em que tal sentido se constitui. Segundo Pêcheux ([1971] 2011, p. 73], “as palavras 'mudam de sentido' ao passar de uma formação discursiva 
para outra", ou ainda, "as palavras mudam de sentido segundo as posições sustentadas por aqueles que as empregam". Nos dizeres que analisamos, as modalizações determinam pelo menos mais de uma formação discursiva, como vimos, por exemplo, no caso em que o discurso oficial demanda a isenção de erros e, posteriormente modalizando, afirma que não foram encontrados erros significativos na coleção e atenta para a necessidade de correção de falhas. Portanto, a posição sustentada pelo sujeito enunciador no primeiro dizer defende a isenção de erros e, mais adiante no mesmo documento, outras posições são sustentadas por esse mesmo sujeito enunciador do discurso oficial.

Parece-nos, portanto, que mesmo sendo a enunciação formulada a partir da memória ou da "perspectiva do dizível” (ORLANDI, E., 1999, p. 33), ela não é apenas determinada pelo interdiscurso, mas também, retroativamente, o determina. Isto é, observamos que a modalização opera um jogo entre o interdiscurso e o intradiscurso, produzindo um movimento em que cada significação remete a outra; isto é, o sentido não para de não se estabilizar. Lembramos aqui que a análise da modalização de erro para falha, na dispersão do discurso, sugere esse movimento de não estabilização de sentido como sendo: um erro é uma falha uma falha não é um erro - tal falha é um erro - tal falha não é um erro etc. Podemos lembrar, também, que o dizer "é conveniente" suscita, como observamos acima, múltiplas significações.

É certo que o sentido sempre pode ser outro; mesmo assim, o dizer afetado pelos princípios moduladores, isto é, a modalização da enunciação, marca já no fio do discurso, na materialidade linguística do dizer, a não estabilização de sentido que ocorrerá no interdiscurso ao remeter a possibilidades de sentido. Porém, como analisamos, as representações se mantêm. A modalização assume, assim, a função discursiva de garantir a ilusão de possibilidades de sentido enquanto produz no discurso a mesma representação historicamente marcada que se mantém forte e resistindo às linhas de fuga. Esses são, contudo, efeitos percebidos no discurso marcado pelo funcionamento da sociedade de controle que, para Deleuze, se assemelha àquele da sociedade de soberania, cujos meios estariam agora “devidamente adaptados" (DELEUZE, G., [1990] 2008, p. 225).

A percepção desses efeitos discursivos produzidos pela modalização nos leva a considerar a possibilidade de o acontecimento discursivo não estar se constituindo a partir de um "ponto de encontro de uma atualidade e uma memória", uma vez que essa "atualidade", ao remeter às mesmas significações, inexiste. O acontecimento discursivo estaria, então, se apresentando como a atualização de uma memória. Uma memória constituída de representações que historicamente habitam o imaginário dos sujeitos do discurso é marcada 
pelo funcionamento dos princípios moduladores que, ao produzirem o efeito de adiamento do fim e oferecerem linhas de fuga através das modalizações, apontam a possibilidades de sentido ao mesmo tempo em que garantem as mesmas representações, os mesmos efeitos de sentido. 


\section{REFERÊNCIAS BIBLIOGRÁFICAS}

AUTHIER-REVUZ, J. Entre a transparência e a opacidade: um estudo enunciativo do sentido. Porto Alegre: EDIPUCRS, 2004.

Palavras incertas: as não-coincidências do dizer. Campinas: Ed. Unicamp, 2001.

- Heterogeneidade(s) Enunciativa(s). In: ORLANDI, E.; GERALDI, J. W. (orgs.)

Cadernos de estudos lingüísticos, no. 19. Campinas. IEL, 1990. p. 25-42.

ALTHUSSER, L. Ideologia e aparelhos ideológicos do estado: notas para uma investigação. Lisboa: Editorial Presença, 1980.

BAUMAN, Z. ; VECCHI, B. Identidade: entrevista a Benedetto Vecchi. Rio de Janeiro: Ed. Jorge Zahar, [2004] 2005.

BITTENCOURT, C. Autores e editores de compêndios e livros de leitura (1810-1910). In: Educação e Pesquisa, São Paulo, v.30, n.3, p. 475-491, set./dez. 2004.

BOURDIEU, P. Leitura, leitores, letrados, literatura: uma prática cultural. In: . Coisas ditas. São Paulo: Ed. Brasiliense, 1990, p. 134-148.

BRANDÃO, H. Introdução à Análise do Discurso. 2. ed.. Campinas: Editora Unicamp, 2004.

BRASIL. Decreto-lei 93 de 21 de dezembro de 1937. Transforma o Instituto Cairu em Instituto Nacional do Livro (INL) e estabelece suas atribuições. Disponível em: $<$ http://legislacao.planalto.gov.br/legisla/legislacao.nsf/Viw_Identificacao/lei\%203781937?OpenDocument>. Acesso em: 16 fev. 2013.

. Diário Oficial da União de 27 de dezembro de 1937. Exposição de Motivos. Seção 1, p. 25586. Disponível em: <http://www2.camara.leg.br/legin/fed/declei/1930-1939/decreto-lei93-21-dezembro-1937-350842-exposicaodemotivos-75476-pe.html>. Acesso em: 18 fev. 2013.

Ministério da Educação. Decreto 19.402 de 14 de novembro de 1930. Dispõe da criação da Secretaria de Estado denominada Ministério dos Negócios da Educação e Saúde Pública. Disponível em: 〈http://portal.mec.gov.br/arquivos/pdf/d19402.pdf〉. Acesso em: 15 fev. 2013.

. Ministério da Educação. Fundo Nacional de Desenvolvimento da Educação: FNDE. Histórico. Disponível em: <http://www.fnde.gov.br/programas/livro-didatico/livro-didaticohistorico>. Acesso em: 27 fev. 2011.

Ministério da Educação. Fundo Nacional de Desenvolvimento da Educação: FNDE. Livro didático. Edição do Decreto n ${ }^{\circ}$ 91.542, de 19/8/85: o Plidef dá lugar ao Programa Nacional do Livro Didático (PNLD). Disponível em: <http://www.fnde.gov.br/index.php/pnld-historico>. Acesso em: 15 e 18 mar. 2011. 
BRASIL. Ministério da Educação. Fundo Nacional de Desenvolvimento da Educação: FNDE. Livro didático. Resolução $\mathrm{n}^{\mathrm{o}} 6$ de julho de 1993. Disponível em: <http://www.fnde.gov.br/index.php/programas-livro-didatico>. Acesso em: 18 mar. 2011.

Ministério da Cultura. 200 anos da Imprensa Régia. Disponível em: <http://www.cultura.gov.br/site/2008/04/22/200-anos-da-impressao-regia〉. Acesso em: 09 mar. 2011.

—. Ministério da Educação. História do MEC. Disponível em: $\langle$ http://portal.mec.gov.br/index.php?option=com_content\&view=article\&id=2\&Itemid=171 > . Acesso em: 05 mar. 2011.

. Ministério da Educação. Fundo Nacional de Desenvolvimento da Educação: FNDE. Compromissos da escolar Disponível em: <ftp://ftp.fnde.gov.br/web/livro_didatico/pnld2011_compromissos_da_escola.pdf〉. Acesso em: 23 ago. 2010.

. Ministério da Educação. Parecer CNE/CEB n. 12/2010, de 8 de julho de 2010. Diretrizes Operacionais para a matrícula no Ensino Fundamental e na Educação Infantil. Disponível em: 〈http://portal.mec.gov.br>. Acesso em: 19 mar. 2011.

Ministério da Educação e Saúde Pública. Plano Nacional de Educação.

Questionário para um inquérito. Rio de Janeiro: Imprensa Nacional, 1936.

Ministério da Justiça. O arquivo nacional e a história luso-brasileira. Conjunto documental: Junta do Comércio. Aulas de Comércio. Ementa: determinações estabelecidas pela Junta do Comércio de Portugal em 1767 acerca da disciplina e do comportamento necessário nas aulas de comércio. Disponível em: $<$ http://www.historiacolonial.arquivonacional.gov.br/cgi/cgilua.exe/sys/start.htm?infoid=749

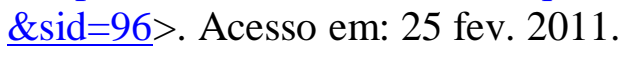

2011.

Portal do Planalto. Disponível em: <www.planalto.gov.br>. Acesso em: 10 mar.

Portal da Imprensa Nacional. Disponível em: <http://portal.in.gov.br/imprensa1/aimprensa-nacional/>. Acesso em: 9 mar. 2011.

Portal do INEP: Instituto Nacional de Estudos e Pesquisas Educacionais Anísio Teixeira. Disponível em: 〈http://www.inep.gov.br/institucional/historia.htm>. Acesso em: 10 de mar. 2011.

Senado

Federal.

Disponível em:

$\overline{<\mathrm{http}}$ ///www6.senado.gov.br/legislacao/ListaTextoIntegral.action?id=76500\&norma=103227 >. Acesso em: 18 fev. 2013.

BRITO, S. A educação no projeto nacionalista do primeiro governo Vargas (1930-1945). In: Navegando na história da educação brasileira - HISTEDBR. Universidade Estadual de Campinas. em: $<$ http://www.histedbr.fae.unicamp.br/navegando/artigos frames/artigo 101.html $>$. Acesso em: 28 fev. 2011. 
BRITTO, T. F. O livro didático, o mercado editorial e os sistemas de ensino apostilados. In: Centro de Estudos da Consultoria do Senado: Textos para Discussão 92. Jun. 2011. Disponível em: <http://www.senado.gov.br/conleg/centroaltosestudos1.html>. Acesso em: 23 fev. 2013.

CARMAGNANI, A., 1999. Ensino apostilado e a venda de novas ilusões. In: CORACINI, M. J. (org.) Interpretação, autoria e legitimação do livro didático. Campinas: Pontes, 1999.

CASSIANO, C. C. F. Mercado editorial escolar do século XXI: livros didáticos, apostilas e formação de professores. (s/d) Disponível em: <www.utp.br/Cadernos_de_Pesquisa/.../2_mercado_editorial_cp6.pdf $>$. Acesso em: 25 fev. 2013.

CHARTIER, R. Do livro à leitura. In: Práticas da leitura. São Paulo: Estação Liberdade, [1945]1996, p. 77-105.

CHERVEL, André. História das disciplinas escolares: reflexões sobre um campo de pesquisa. In: Teoria e Educação, n. 2. Porto Alegre, 1990, p. 117-229.

CORACINI, M. J. Interpretação, autoria e legitimação do livro didático (org.). Campinas: Pontes, 1999.

- O olhar da ciência e a construção da identidade do profesor de língua. In: CORACINI, M. J.; BERTOLDO, E. (orgs.) O desejo da teoría e a contingência da prática: discursos sobre/na sala de aula. Campinas: Mercado de Letras, 2003, p. 193-210.

CORACINI, M. J. A escamoteação da heterogeneidade. In: CORACINI, M. J.; BERTOLDO, E. (orgs.) $O$ desejo da teoría e a contingencia da prática: discursos sobre/na sala de aula. Campinas: Mercado de Letras, 2003, p. 251-268.

COURTINE, J-J. Discursos sólidos, discursos líquidos: a mutação das discursividades contemporáneas. In: SARGENTINI, V.; GREGOLIN, M. R. Análise do discurso: heranças, métodos e objetos. São Carlos: Claraluz, 2008, p. 11-19.

Análise do discurso político - o discurso comunista endereçado aos cristãos. São Carlos: Edufscar, [1981] 2009.

DEACON, R.; PARKER, B. Educação como sujeição e como recusa. In: SILVA, T. T. (org.), O sujeito da educação. Petrópolis: Ed. Vozes, 1995, p. 97-110.

DELEUZE, G. Foucault. São Paulo: Brasiliense, [1986] 1988, 6ª reimpressão: 2005.

Conversações: 1972-1990. São Paulo: Ed. 34, [1990] 1992, 7ª reimpressão: 2008.

; GUATTARI, F. Mil platôs: capitalismo e esquizofrenia. Vol. 1. Trad. Aurélio Guerra Neto e Celia Pinto Costa. São Paulo: ed. 34, [1980] 1995.

.; GUATTARI, F. O anti-Édipo. São Paulo: Ed. 34, [1972/1973] 2010. 
DIAS, R.; CRISTOVÃO, V. L. L. (orgs). O livro didático de língua estrangeira: múltiplas perspectivas. Campinas: Mercado de Letras, 2009.

DIONÍSIO, A. P. Livros didáticos de Português formam professores? In: Congresso Brasileiro de Qualidade na Educação. Simpósio 6: O livro didático e a formação de professores. Publicado online em 01 jan. 2008, p. 82-88. Disponível em: <http://portal.mec.gov.br/seb/arquivos/pdf/vollb.pdf>. Acesso em: 19 mar. 2013.

DUFOUR, D-R. A arte de reduzir as cabeças. Rio de Janeiro: Companhia de Freud, [2003] 2005.

EDUCAR BRASIL. Portal Educar Brasil. Disponível em: $\langle$ http://educarbrasil.org.br/Portal.Base/Web/VerContenido.aspx?ID=206628 > . Acesso em: 10 mar. 2011.

FOUCAULT, M. O que é um autor? 5ª ed. Alpiarça: Ed. Veja, [1969] 2002.

A arqueologia do saber. $7^{\text {a }}$ ed. Rio de Janeiro: Forense Universitária, [1969] 2008.

A ordem do discurso. 11ª ed. São Paulo: Ed. Loyola, [1971] 2004.

Vigiar e punir. 29a ed. Petrópolis: Ed. Vozes, [1975] 2004.

Microfísica do poder. 20ª ed. Rio de Janeiro: Ed. Graal, [1979] 2004.

. The subject and power. In: DREYFUS, H. L.; RABINOW, P., Michel Foucault: beyond structuralism and hermeneutics. New York: Harvester Wheatsheaf, 1982.

O sujeito e o poder. In: DREYFUS, H. L.; RABINOW, P., Michel Foucault: uma trajetória filosófica para além do estruturalismo e da hermenêutica. Rio de Janeiro: Ed. Forense Universitária, 1995.

GALLO, S. Deleuze e a educação. $2^{a}$ ed. Belo Horizonte: Autêntica, 2003.

GORE, J. Foucault e a educação: fascinantes desafios. In: SILVA, T. T. (org.), O sujeito da educação. Petrópolis: Ed. Vozes, [1994] 2ª ed. 1995, p. 9-20.

GRIGOLETTO, M. Leitura e funcionamento discursivo do livro didático. In: CORACINI, M. J. (org.). Interpretação, autoria e legitimação do livro didático. Campinas: Pontes, 1999, p. 67-77.

GUILHAUMOU, J.; MALDIDIER, D. Efeitos do arquivo. A análise do discurso no lado da história. [1986] In: ORLANDI, E. (org.) Gestos de leitura. Campinas: Ed. Unicamp, $3^{\mathrm{a}}$ ed. 2010, p. 161-183.

HALL, S. A identidade cultural na pós-modernidade. Rio de Janeiro: Ed. DP\&A, [1992] 2003.

HAROCHE, C. Fazer dizer, querer dizer. São Paulo: Hucitec, [1984] 1992. 
HENRY, P. Construções relativas e articulações discursivas. In: ORLANDI, E.; GERALDI, J. W. (orgs.) Cadernos de estudos linguísticos, no. 19. Campinas: IEL, UNICAMP. 1990. p. 43-64.

INSTITUTO SOCIOAMBIENTAL (ISA). Disponível em: <http://pib.socioambiental.org/pt/c/no-brasil-atual/linguas/troncos-e-familias>. Acesso em: 18 mar. 2011.

JORGE, M. A. C. Fundamentos da Psicanálise de Freud a Lacan: as bases conceituais. Rio de Janeiro: 2002.

JUSBRASIL. Diários oficiais. Disponível em: 〈http://www.jusbrasil.com.br/diarios/2617701/dou-secao-1-28-12-1945-pg-8/pdfView >.

Acesso em: 15 mar. 2011.

MARIANI, B. O PCB e a imprensa: os comunistas no imaginário dos jornais (1922 1989). Campinas/Rio de Janeiro: Ed. Unicamp/Ed. Revan, 1999.

MUNAKATA, K. Livro didático e formação do professor são incompatíveis? In: Congresso Brasileiro de Qualidade na Educação. Simpósio 6: O livro didático e a formação de professores. Publicado online em 01 jan. 2008, p. 89-94. Disponível em: <http://portal.mec.gov.br/seb/arquivos/pdf/vollb.pdf>. Acesso em: 19 mar. 2013.

OLIVEIRA, L. A instituição do ensino de línguas vivas no Brasil: o caso da língua inglesa (1809-1890). 378 p. Tese de doutorado em Educação: História, Política, Sociedade. PUC-SP, São Paulo, 2006.

. ; CARDOSO, J. Considerações sobre o ensino de línguas no Brasil: da instituição do método direto à primeira versão da LDB. In: Revista HELB, ano 3, n. 3. Programa de PósGraduação em Linguística Aplicada da Universidade de Brasília, 2009.

ORLANDI, E. Análise de Discurso - princípios e procedimentos. Campinas: Ed. Pontes, 1999.

Discurso e texto: formulação e circulação dos sentidos. $3^{\text {a }}$ ed. Campinas: Ed. Pontes, [2001] 2008.

Interpretação: autoria, leitura e efeitos do trabalho simbólico. $5^{\mathrm{a}}$ ed. Campinas: Ed. Pontes, 2007.

PAIVA, V. História do material didático de língua inglesa no Brasil. In: DIAS, R.; CRISTOVÃO, V. (orgs.) O livro didático de língua estrangeira: múltiplas perspectivas. Campinas: Mercado de Letras, 2009, p. 17-56.

Ensino de língua inglesa: antecipando uma pedagogia pós-moderna. Disponível em: 〈http://www.veramenezes.com/solange1.pdf>. Acesso em: 21 fev. 2013.

PÊCHEUX, M. Língua, linguagens, discurso. In: PIOVEZANI, C.; SARGENTINI, V. (orgs.) Legados de Michel Pêcheux: inéditos em análise do discurso. São Paulo: Contexto, [1971] 2011, p. 63-75. 
PÊCHEUX, M. Semântica e discurso: uma crítica à afirmação do óbvio. Campinas: Ed. Unicamp, [1975] 2009.

.O Discurso: Estrutura ou acontecimento. $3^{\mathrm{a}}$ ed. Campinas: Ed. Pontes, [1983] 2002.

PEDAGOGIA EM FOCO. BELLO, J. L. P. (org.). Disponível em: <http://www.pedagogiaemfoco.pro.br/heb07a.htm>. Acesso em: 25 fev. 2011.

POVOS INDÍGENAS NO BRASIL. Fany Pantaleoni Ricardo (coord.) Disponível em: $<$ http://pib.socioambiental.org/pt/c/no-brasil-atual/linguas/troncos-e-familias $>$. Acesso em: 18 mar. 2011.

SÃO PAULO. Orientações CENP para a escolha de livros didáticos do PNLD 2012. Coordenação Nacional do PNLD em São Paulo - Equipe Técnica da CENP/SEE-SP. Disponível em: <http://pnld.edunet.sp.gov.br/2012/Arquivos/Orientacoes_Geral.pdf>. Acesso em: 06 fev. 2013.

SCHWARTZMAN, S.; BOMENY, H. M. B.; COSTA, V. M. R., [1984] 2000. Tempos de Capanema.

Disponível

em:

<http://www.schwartzman.org.br/simon/capanema/introduc.htm>. Acesso em: 11 fev. 2013.

SERRANI-INFANTE, S. Formações discursivas e processos identificatórios na aquisição de línguas. In: Delta: Documentação de Estudos em Linguística Teórica e Aplicada. Vol. 13, n.1. São Paulo, 1997. Disponível em: <http://www.scielo.br/scielo.php?pid=S010244501997000100004\&script=sci_arttext>. Acesso em: $01 \mathrm{dez} 2013$.

SILVA, V.; CORREIA, A. Saberes em viagem nos manuais pedagógicos (Portugal-Brasil). In: Cadernos de Pesquisa. São Paulo, vol.34, nº123, 2004, p.613-622. 2004.

SOUZA, D. Autoridade, autoria e livro didático. In: CORACINI, M. J. (org.). Interpretação, autoria e legitimação do livro didático. Campinas: Pontes, 1999, p. 27-31.

TOMLINSON, B. Materials Development in language teaching. $2^{\text {a. }}$ ed. Cambridge: Cambridge University Press, 2011.

UNIVERSIDADE DE BRASÍLIA. História do ensino de Línguas no Brasil - HELB. Projeto do Programa de Pós-Graduação em Linguística Aplicada da Universidade de Brasília. Disponível em: 〈www.helb.org.br〉. Acesso em: 29 ago. 2010; 20, 27 e 28 fev. 2011.

UNIVERSIDADE DE SÃO PAULO. Faculdade de Educação. Livres: Banco de dados de livros escolares brasileiros (1810 a 20005). Circe Maria Fernandes Bittencourt (coord.). Disponível em: <http://www2.fe.usp.br/estrutura/livres/index.htm>. Acesso em: 04 dez. 2010.

UNIVERSIDADE DO PORTO. Biblioteca digital. Disponível em: <http://ler.letras.up.pt/uploads/ficheiros/artigo7581.pdf> . Acesso em: 10 mar. 2011.

UNIVERSIDADE ESTADUAL DE CAMPINAS. Grupo de Estudos e Pesquisas História, Sociedade e Educação no Brasil - HISTEDBR. Dermeval Saviani (coord.). Disponível em: <http://www.histedbr.fae.unicamp.br>. Acesso em: 27 e 28 fev. 2011. 
UNIVERSIDADE ESTADUAL DE CAMPINAS. Laboratório de Estudos Urbanos LABEURB. Eduardo Guimarães (coord.). Disponível em: <http://www.labeurb.unicamp.br/elb/portugues/portugues_brasil.htm>. Acesso em: 16 fev. 2011.

VIDOTTI, J.J.V. Políticas linguísticas para o ensino de língua estrangeira no Brasil do século XIX, com ênfase na língua inglesa. 247 p., Tese de doutorado em Letras, Universidade de São Paulo, Faculdade de Filosofia, Letras e Ciências Humanas, São Paulo. 2012.

XAVIER, M. Capitalismo e escola no Brasil: a constituição do liberalismo em ideologia educacional e as reformas do ensino (1931-1961). Campinas: Papirus, 1990.

WILLIAMS, G. French Discourse Analysis: the method of post-structuralism. London/New York: Routledge, [1999] 2005.

ŽIŽEK, S. Um mapa da ideologia. Rio de Janeiro: Ed. Contraponto, [1994] 2007.

Bem-vindo ao deserto do real! São Paulo: Boitempo Editorial, [2002] 2003.

Arriscar o impossível. São Paulo: Ed. Martins Fontes, [2004] 2006. 


\section{BIBLIOGRAFIA DO CORPUS DE PESQUISA}

AGÊNCIA DE NOTÍCIAS AMARILDO MELO. Livro Didático: Secretarias e escolas devem fazer a adesão até o dia 30. Brasileira, PI. Disponível em: <www.amarildomelo.com.br $>$. Acesso em: 19 jun. 2010.

AGÊNCIA DE NOTÍCIAS PORTAL CT. Escolas estaduais entregam livros didáticos nesta sexta-feira em momento cívico. Palmas, TO. Disponível em: <http://www.portalct.com.br/>. Acesso em: 30 mai. 2010.

AGÊNCIA DE NOTÍCIAS 45 GRAUS. Escolas escolhem livro didático para 2011. Teresina, PI. Disponível em: 〈www.45graus.com.br〉. Acesso em: 21 jun. 2010.

AGÊNCIA DE NOTÍCIAS PRIMEIRA HORA. Alunos da rede pública receberão livros de inglês e espanhol a partir de 2011. Rondonópolis, Mato Grosso. Disponível em: <http://www.primeirahora.com.br >. Acesso em: 30 mai. 2011.

AGÊNCIA DE NOTÍCIAS TERRA. Terra Networks Brasil S.A.. Escolha de livros didáticos para 2011 tem início na segunda. Porto Alegre, RS. Disponível em: $<$ http://noticias.terra.com.br $>$. Acesso em: 18 jun. de 2010.

AGÊNCIA DE NOTÍCIAS BRASILEIRACITY. Livro didático - Programa terá este ano aquisição recorde de 135 milhões de exemplares. Brasileira, PI. Disponível em: <www.brasileiracity.com.br >. Acesso em: 25 fev. 2011.

AGÊNCIA DE NOTÍCIAS WSCOM. Estados e municípios devem aderir até quarta a programa do livro didático. João Pessoa, PB. Disponível em: 〈www.wscom.com.br〉. Acesso em: 25 fev. 2011.

AGÊNCIA DE NOTÍCIAS FOLHA.COM. MEC inicia em 2009 compra de livros de idiomas para escolas públicas. São Paulo, SP. Disponível em: <http://www1.folha.uol.com.br/folha/educacao >. Acesso em: 22 fev. 2011.

ANDIFES - ASSOCIAÇÃO NACIONAL DOS DIRIGENTES DAS INSTITUIÇÕES DE ENSINO SUPERIOR. Livro didático - Programa terá este ano aquisição recorde de 135 milhões de exemplares. Disponível em: <www.andifes.org.br $>$. Acesso em: 10 mar. 2011.

BRASIL. Decreto-Lei NP 8.460, de 26 de dezembro de 1945. Consolida a legislação sobre as condições de produção, importação e utilização do livro didático e utilização do livro didático. Disponível em: 〈http://www.fnde.gov.br/index.php/pnld-historico>. Acesso em: 15 mar. 2011.

. Ministério da Educação. Fundo Nacional de Desenvolvimento da Educação: FNDE.

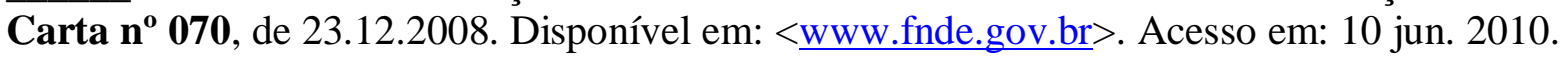

. Ministério da Educação. Fundo Nacional de Desenvolvimento da Educação: FNDE. Carta Circular n. ${ }^{\circ}$ 04/2010-FNDE/MEC. Brasília, abril de 2010. Disponível em: <www.fnde.gov.br>. Acesso em: 10 jun. 2010. 
BRASIL. Ministério da Educação. Fundo Nacional de Desenvolvimento da Educação: FNDE. Edital de Convocação para Inscrição no Processo de Avaliação e Seleção de Coleções Didáticas, para o Programa Nacional do Livro Didático - PNLD 2011. Disponível em: <www.fnde.gov.br>. Acesso em: 08 fev. 2010.

Guia Ministério da Educação. Fundo Nacional de Desenvolvimento da Educação: FNDE.
de livros didáticos - PNLD 2011. Disponível em: < http://www.fnde.gov.br/index.php/pnld-guia-do-livro-didatico/2349-guia-pnld-2011>. Acesso em: 10 jun. 2010.

. Ministério da Educação. Fundo Nacional de Desenvolvimento da Educação: FNDE. Orientações para o registro da escolha. Disponível em: <ftp://ftp.fnde.gov.br/web/livro_didatico/pnld2011_compromissos_da_escola.pdf $>$. Acesso em: 23 ago. 2010.

. Ministério da Educação. Fundo Nacional de Desenvolvimento da Educação: FNDE. Valores Negociados e Resumo Físico Financeiro do PNLD 2011. Disponível em: <www.fnde.gov.br/index.php/edital-pnld $>$. Acesso em: 10 mar. 2011.

. Ministério da Educação. Fundo Nacional de Desenvolvimento da Educação: FNDE. Resolução $\mathbf{n}^{\mathbf{0}} \mathbf{6 0}$, de 20 de novembro de 2009. Alterada pela Resolução no 10 , de 10 de março de 2011, ambas dispõem sobre o Programa Nacional do Livro Didático (PNLD) para a educação básica. Disponíveis em: 〈http://www.fnde.gov.br/index.php/leg-res-2011〉. Acesso em: 20 mar. 2011.

CURSO UNIVERSITÁRIO - RGS. Alunos terão livros de inglês e espanhol. Disponível em: <http://www.universitario.com.br>. Acesso em: 21 jul. 2012.

ESCOLA Estadual Professor Gerson Lopes. Entrega do livro didático. Apodi, RN. Disponível em: <http://escolaestadualprofessorgersonlopes.blogspot.com>. Acesso em: 10 mar. 2011.

ESCOLA Estadual Dr. Euzébio Dias Bicalho. Livro Didático Na Escola Estadual Dr. Euzébio Dias Bicalho. Belo Horizonte, MG. Disponível em: <http://euzebiodiasbicalho.arteblog.com.br>. Acesso em: 10 mar. 2011.

RORAIMA. SECD - Secretaria de Educação, Cultura e Desportos, Governo do Estado de Roraima. Professores estaduais escolhem livros didáticos. Disponível em: <http://www.educacao.rr.gov.br/>. Acesso em: 18 mar. 2011.

SIMPÓSIO SOBRE O LIVRO DIDÁTICO DE LÍNGUA MATERNA E ESTRANGEIRA, III; SIMPÓSIO SOBRE MATERIAIS E RECURSOS DIDÁTICOS, II, 28, 29 e 30 de julho de 2010, PUC-RIO. Anais do III Simpósio sobre o Livro Didático de Língua Materna e Estrangeira e do II Simpósio sobre Materiais e Recursos Didáticos. Rio de Janeiro: Edições $\quad$ Entrelugar, 2010. Disponível em: <http://ler.letras.up.pt/uploads/ficheiros/artigo7581.pdf>. Acesso em: 23 nov. 2013. 


\section{APÊNDICE - LEVANTAMENTO SOBRE TRABALHOS NA ÁREA - CONJUNTO DA PRODUÇÃO}

\section{TRABALHOS SOBRE O DISCURSO SOBRE O LIVRO DIDÁTICO DE INGLÊS}

\begin{tabular}{|c|c|}
\hline 1. TÍTULO & $\begin{array}{l}\text { Ouvindo a voz do (pré)adolescente brasileiro da geração digital sobre o } \\
\text { livro didático de inglês desenvolvido no Brasil }\end{array}$ \\
\hline AUTOR & MARCIA CASTELO BRANCO NOGUEIRA \\
\hline TIPO DE PRODUÇÃO & Dissertação de mestrado \\
\hline ÁREA & Ensino de Língua Estrangeira: escola da rede privada/ instituto \\
\hline DATA & 28/08/2007 \\
\hline $\begin{array}{l}\text { LOCAL DA } \\
\text { PUBLICAÇÃOO }\end{array}$ & Pontifícia Universidade Católica do Rio de Janeiro - PUC-Rio \\
\hline RESUMO & $\begin{array}{l}\text { Essa pesquisa consiste na investigação dos aspectos de um livro didático de } \\
\text { inglês que os alunos apreciam e acham motivadores. O livro- texto selecionado } \\
\text { é uma série didática de inglês desenvolvida especialmente para } \\
\text { (pré)adolecentes brasileiros de um curso livre de língua inglesa. Através de } \\
\text { pesquisas com os alunos usuários da série selecionada, descobriram-se as três } \\
\text { principais características que eles aprovam nesse material: os textos } \\
\text { trabalhados, o seu layout e a sua abordagem gramatical. Posteriormente, esses } \\
\text { aspectos do livro didático-alvo foram analisados cuidadosamente sob a ótica de } \\
\text { teorias relacionadas a eles: a teoria de gêneros discursivos, a teoria de } \\
\text { multimodalidade e teorias sobre o processo ensino/aprendizagem de gramática } \\
\text { da língua estrangeira. A análise do material ajudou-nos a compreender a razão } \\
\text { pela qual os alunos aprovam esses aspectos e corroborou com a sua escolha. }\end{array}$ \\
\hline Nosso parecer & $\begin{array}{l}\text { O trabalho analisa o LDI como um gênero discursivo e sob a ótica da teoria de } \\
\text { multimodalidades. Trata-se de uma pesquisa quantitativa, com aspectos } \\
\text { positivistas e estruturalistas. Apenas no capítulo } 9 \text { há a aproximação com o } \\
\text { trabalho que desenvolvemos. No capítulo } 9 \text {, o trabalho investiga a opinião dos } \\
\text { alunos adolescentes sobre o LDI. Temos, então, um recorte do estudo sobre o } \\
\text { discurso sobre o LDI; porém, a voz do aluno não se encaixa em nenhum dos } \\
\text { nossos recortes de corpus (profissional, midiático e oficial). }\end{array}$ \\
\hline 2. TÍTULO & O que os alunos pensam sobre o livro didático de inglês? \\
\hline AUTOR & XAVIER, Rosely Perez e SOUZA, Daniele Tristão de \\
\hline TIPO DE PRODUÇÃO & $\begin{array}{l}\text { Trabalhos em Linguística Aplicada [online]. 2008, vol.47, n.1, pp. 65-89. ISSN } \\
0103-1813 \text {. DOI: } 10.1590 / \text { S0103-18132008000100005 }\end{array}$ \\
\hline ÁREA & Linguística Aplicada \\
\hline DATA & 2008 \\
\hline $\begin{array}{l}\text { LOCAL DA } \\
\text { PUBLICACCÃO }\end{array}$ & Unicamp/IEL/Setor de Publicações \\
\hline RESUMO & $\begin{array}{l}\text { Este trabalho investiga a relação que alunos do ensino fundamental e médio, } \\
\text { bem como aqueles que cursam escola de idiomas, estabelecem com o livro } \\
\text { didático de inglês. Um total de } 260 \text { alunos da cidade de Caçador, SC, } \\
\text { respondeu a um questionário com perguntas sobre suas opiniões e } \\
\text { posicionamento crítico quanto a esse recurso. Os dados foram analisados a } \\
\text { partir de um panorama geral e contextual, visando encontrar pontos de } \\
\text { convergência e divergência entre os adolescentes. Foi possível concluir que a } \\
\text { metodologia de ensino adotada pelas professoras parece influenciar nas } \\
\text { concepções dos alunos sobre o que um LD/ uma apostila de inglês deve } \\
\text { oferecer e como deve ser avaliado(a). }\end{array}$ \\
\hline Nosso parecer & $\begin{array}{l}\text { Apesar do titulo, o artigo analisa o LDI como objeto. A pergunta do título só será } \\
\text { investigada no item } 5 \text { do artigo. Ainda no item } 6 \text {, os alunos falam sobre as } \\
\text { vantagens e desvantagens do LDI. Item 7: avaliação do LDI no olhar do aluno. } \\
\text { O trabalho usa porcentagens de respostas para analisar os resultados das } \\
\text { entrevistas com os alunos. O trabalho não diferencia o LDI (adotado na escola } \\
\text { privada e no curso livre) da apostila (usada na escola pública). }\end{array}$ \\
\hline 3. TÍTULO & $\begin{array}{l}\text { Estudos recentes em Linguística Aplicada no Brasil a respeito de livros } \\
\text { didáticos de língua estrangeira }\end{array}$ \\
\hline AUTOR & Renato Caixeta da Silva - CEFET-MG / PUC-Rio \\
\hline TIPO DE PRODUÇÃO & Trabalho de final de curso de disciplina de pós-graduação \\
\hline ÁREA & Linguística aplicada \\
\hline DATA & 2010 \\
\hline $\begin{array}{l}\text { LOCAL DA } \\
\text { PUBLICACÃ̃O }\end{array}$ & RBLA, Belo Horizonte, v. 10, n. 1, p. 207-226, 2010 \\
\hline
\end{tabular}




\begin{tabular}{|c|c|}
\hline RESUMO & $\begin{array}{l}\text { RESUMO: Este trabalho focaliza pesquisas brasileiras sobre livros didáticos } \\
\text { (LD) de língua estrangeira em Linguística Aplicada. Considera-se o lugar } \\
\text { ocupado na área por pesquisas sobre material didático para o ensino de línguas } \\
\text { estrangeiras (CORACINI, 1999; FRACALANZA; SANTORO, 1989; MOITA } \\
\text { LOPES, 1999; dentre outros), e é apresentado um panorama das pesquisas em } \\
\text { Linguística Aplicada no Brasil envolvendo o LD de línguas estrangeiras no } \\
\text { período de } 1998 \text { a 2008, mostrando os temas enfocados mais recentemente } \\
\text { nestas pesquisas. Para tal, foram consultadas páginas da internet dos } \\
\text { programas de pós-graduação em Linguística Aplicada, Estudos da Linguagem } \\
\text { ou Línguas Estrangeiras de universidades brasileiras, bem como revistas } \\
\text { especializadas na área, e, por fim, foi considerada a realização do I SILID e II } \\
\text { SILID/ISIMAR na PUC-Rio, eventos específicos sobre o LD de línguas. Ao final, } \\
\text { são apresentados novos temas e tendências de pesquisas, as implicações de } \\
\text { investigações envolvendo LD de línguas estrangeiras e a necessidade de } \\
\text { diálogos entre pesquisadores e professores (KRAMSCH, 1995; CORACINI, } \\
\text { 1999). }\end{array}$ \\
\hline Nosso parecer & $\begin{array}{l}\text { O artigo é uma revisão bibliográfica sobre artigos, trabalhos apresentados em } \\
\text { congressos, teses e dissertações sobre o livro didático de língua estrangeira em } \\
\text { geral. O artigo se aproxima do nosso trabalho por tratar de estudos que tenham } \\
\text { o LDI como objeto e quando algumas vezes o autor relata pontos de vista de } \\
\text { linguistas aplicados ou comenta sobre a insuficiência e a importância de } \\
\text { trabalhos na área; porém, não analisa, mais especificamente, os dizeres sobre o } \\
\text { livro didático de inglês, como meu trabalho propõe. }\end{array}$ \\
\hline 4. TÍTULO & $\begin{array}{l}\text { O livro didático na perspectiva da formação de professores - } \\
\text { The textbook in the perspective of teacher education }\end{array}$ \\
\hline AUTOR & Rosane Rocha Pessoa - UFG, Goiânia (GO) \\
\hline TIPO DE PRODUÇÃO & artigo \\
\hline ÁREA & $\begin{array}{l}\text { Trabalhos em Linguística Aplicada // Print version ISSN 0103-1813 } \\
\text { vol.48 no.1 Campinas Jan./June } 2009 \quad-\quad \text { DOI: } \\
18132009000100005\end{array}$ \\
\hline DATA & 2009 \\
\hline $\begin{array}{l}\text { LOCAL DA } \\
\text { PUBLICAÇÃO }\end{array}$ & Scielo \\
\hline RESUMO & $\begin{array}{l}\text { Há provavelmente tanto razões a favor quanto contra a utilização do livro } \\
\text { didático no ensino de língua estrangeira, mas o fato é que, no Brasil, poucos } \\
\text { são os contextos educacionais em que não se adota um livro didático. A relação } \\
\text { entre essa ampla adoção do livro didático e os modelos tradicionais de } \\
\text { formação profissional, nos quais os professores aprendem a aplicar em suas } \\
\text { práticas pedagógicas teorias produzidas por agentes externos, parece bastante } \\
\text { óbvia. No entanto, nos modelos atuais de formação, que objetivam } \\
\text { principalmente que os professores construam conhecimento sobre ensino e } \\
\text { aprendizagem, será que há espaço para o livro didático ou deveria o professor } \\
\text { criar os seus próprios materiais? Neste texto, abordaremos esse tópico, levando } \\
\text { em consideração a percepção de alunos do curso de graduação em Letras da } \\
\text { UFG sobre a utilização do livro didático no ensino de inglês. }\end{array}$ \\
\hline Nosso parecer & $\begin{array}{l}\text { Esse estudo se assemelha ao nosso na medida em que os dados foram obtidos } \\
\text { a partir da análise dos dizeres de professores. Apesar de as informações terem } \\
\text { sido obtidas também através de um questionário, como no nosso caso, os } \\
\text { dados são recolhidos em tabelas, classificados em tipos de resposta e } \\
\text { quantificados, procedimento este que difere do nosso trabalho. Os entrevistados } \\
\text { são vagamente caracterizados como professores em formação; portanto, ainda } \\
\text { não atuam ou são professores de cursos livres; já que não têm certificação para } \\
\text { atuar como professores em escolas regulares. }\end{array}$ \\
\hline 5. TÍTULO & $\begin{array}{l}\text { O material didático no ensino de língua estrangeira: definições, } \\
\text { modalidades e papéis }\end{array}$ \\
\hline AUTOR & Márcio Luiz Corrêa VILAÇA - UNIGRANRIO \\
\hline TIPO DE PRODUÇÃO & artigo \\
\hline ÁREA & humanidades \\
\hline DATA & Set 2009 \\
\hline $\begin{array}{l}\text { LOCAL DA } \\
\text { PUBLICAÇÃO }\end{array}$ & $\begin{array}{l}\text { Revista Eletrônica do Instituto de Humanidades ISSN-1678-3182 } \\
\text { Volume VIII Número XXX Jul-Set } 2009\end{array}$ \\
\hline RESUMO & $\begin{array}{l}\text { Este artigo discute definições, modalidades e papéis dos materiais didáticos no } \\
\text { ensino de línguas estrangeiras. O objetivo deste trabalho é proporcionar melhor } \\
\text { compreensão sobre o que seja um material didático. Embora este artigo focalize } \\
\text { predominantemente no ensino de línguas estrangeiras, algumas das discussões } \\
\text { aqui realizadas poderão contribuir para outras áreas, especialmente o ensino de } \\
\text { língua materna. }\end{array}$ \\
\hline
\end{tabular}




\begin{tabular}{|c|c|}
\hline Nosso parecer & $\begin{array}{l}\text { O artigo discute o papel do LDI e outros materiais na perspectiva de vários } \\
\text { autores e tece alguns comentários gerais do próprio autor em relação ao papel } \\
\text { dos materiais. Não há análise. }\end{array}$ \\
\hline 6. TÍTULO & Influência das crenças do professor de língua inglesa sobre o aprendizado \\
\hline AUTOR & Maria Aparecida de CASTRO BARBO - Universidade Federal de Goiás \\
\hline TIPO DE PRODUÇÃO & artigo \\
\hline ÁREA & Letras \\
\hline DATA & s/d de publicação. Data da pesquisa de campo: 2004-2005 \\
\hline $\begin{array}{l}\text { LOCAL DA } \\
\text { PUBLICAÇÃO }\end{array}$ & $\begin{array}{l}\text { CCE (Centro de Comunicação e Expressão) - Universidade Federal de Santa } \\
\text { Catarina }\end{array}$ \\
\hline RESUMO & $\begin{array}{l}\text { O objetivo do presente trabalho visa obter uma visão, por amostragem, das } \\
\text { crenças de alguns professores de língua estrangeira (LE), no caso, língua } \\
\text { inglesa (LI), e sua influência no aprendizado. Tomamos como parâmetro as } \\
\text { teorias desenvolvidas por Barcelos (1999) e Moita Lopes (1996) sobre as } \\
\text { expectativas de professores de LE em face à realidade do ensino do idioma em } \\
\text { geral. Trata-se de uma pesquisa de campo, realizada entre os meses de } \\
\text { outubro de } 2004 \text { e fevereiro de } 2005 \text {, cujos dados foram coletados em } \\
\text { entrevistas gravadas com professores de inglês do Ensino Fundamental da rede } \\
\text { pública estadual, em Goiânia, Estado de Goiás, tanto respondendo a um } \\
\text { questionário pré-elaborado, como por contribuição espontânea, onde os } \\
\text { professores manifestaram o que mais os agrada; o que mais os aflige e suas } \\
\text { preocupações e esperanças quanto ao futuro do ensino deste idioma na rede } \\
\text { pública. Os professores contatados concentram-se } \\
\text { na faixa etária dos } 25-40 \text { anos, entre } 05 \text { a } 22 \text { anos de experiência no ensino da } \\
\text { LE. Constatou-se um certo desânimo em relação ao apoio que os professores } \\
\text { recebem dos órgãos públicos, tanto quanto ao provimento de equipamentos } \\
\text { para auxiliar abordagens metodológicas e na conservação do espaço físico } \\
\text { onde as aulas são ministradas, como no suporte de material didático; promoção } \\
\text { de cursos regulares de atualização pedagógica e nível de conhecimento prévio } \\
\text { dos alunos. } \\
\text { Palavras-chave: crenças dos professores de língua inglesa; LE - língua } \\
\text { estrangeira; questionário. }\end{array}$ \\
\hline Nosso parecer & $\begin{array}{l}\text { Esse artigo toma o ensino de língua inglesa como objeto de investigação e não } \\
\text { apenas o livro didático nem discurso sobre o livro didático. Porém, no } \\
\text { questionário, duas perguntas tratam do livro didático: } \\
\text { Pergunta 8: Qual o livro que usa nas suas aulas? E outro material? A Escola } \\
\text { tem fitas,vídeos para a sala de aula? E laboratório? Os alunos têm livro } \\
\text { didático?Trazem para a sala de aula? } \\
\text { Pergunta 9: Quais as providências tomadas pelos responsáveis pelo ensino } \\
\text { público para facilitar o bom desempenho do professor? (Material adotado). } \\
\text { Mesmo assim, o artigo não estuda o discurso sobre o livro didático de inglês } \\
\text { especificamente. Na verdade, as respostas dos professores não são analisadas } \\
\text { individualmente; apenas compõem o argumento sobre reivindicações aos } \\
\text { órgãos governamentais e constatações sobre a má qualidade do ensino de } \\
\text { inglês na escola pública. }\end{array}$ \\
\hline 7. TÍTULO & $\begin{array}{lccccccc}\text { Crenças de } & \text { uma professora } & \text { de língua } & \text { inglesa } & \text { acerca } & \text { do } \\
\text { Ensino/aprendizagem desse idioma }\end{array}$ \\
\hline AUTOR & 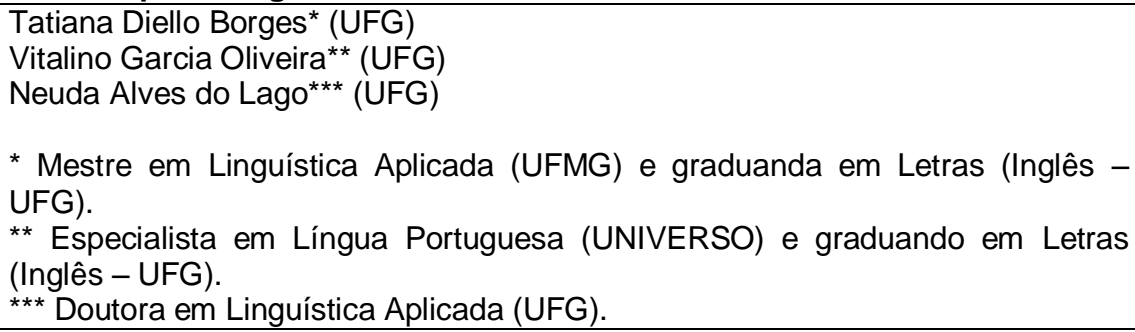 \\
\hline TIPO DE PRODUÇÃO & artigo \\
\hline ÁREA & Letras \\
\hline DATA & $\mathrm{s} / \mathrm{d}$ \\
\hline $\begin{array}{l}\text { LOCAL DA } \\
\text { PUBLICAÇÃO }\end{array}$ & www2.uel.br/revistas/entretextos \\
\hline RESUMO & $\begin{array}{l}\text { O objetivo deste artigo é relatar os resultados obtidos em uma pesquisa } \\
\text { realizada para a Prática como Componente Curricular do curso de Letras/Inglês } \\
\text { da Universidade Federal de Goiás, Campus Jataí - GO. Neste estudo, } \\
\text { procurou-se analisar as crenças de uma professora de inglês em serviço sobre } \\
\text { o processo de ensino/aprendizagem desse idioma. O aparato teórico apoiou-se } \\
\text { em estudos da área de ensino/aprendizagem de línguas estrangeiras que }\end{array}$ \\
\hline
\end{tabular}




\begin{tabular}{|c|c|}
\hline & $\begin{array}{l}\text { tiveram como foco de investigação a questão das crenças. A metodologia } \\
\text { escolhida foi o estudo de caso e os seguintes instrumentos de coleta de dados } \\
\text { foram utilizados: um questionário e observação de aulas. Os resultados } \\
\text { sugerem a crença da participante de que a gramática não seja a } \\
\text { parte mais importante no ensino de inglês, que o lúdico e a pronúncia devem } \\
\text { estar sempre presentes e que é possível aprender esta língua na escola pública. }\end{array}$ \\
\hline Nosso parecer & $\begin{array}{l}\text { Este estudo pesquisa sobre o ensino de inglês de modo geral e não } \\
\text { especificamente sobre o LDI. Em duas perguntas do questionário, é possível } \\
\text { encontrar o discurso sobre o LDI: (9) é possível ensinar inglês sem livro } \\
\text { didático?; (10) recursos didáticos como apostilas, textos avulsos podem facilitar } \\
\text { o ensino de língua inglesa? Porém, a noção de crença (que mantém distância } \\
\text { da noção de representação em Análise do Discurso pecheutiana) é analisada no } \\
\text { conjunto de crenças sobre o ensino de inglês. O estudo parece apenas } \\
\text { confirmar o que já se esperava antes mesmo de iniciá-lo, como se tivesse uma } \\
\text { função ilustrativa; acreditamos que haveria espaço para a exploração mais } \\
\text { aprofundada do tema. }\end{array}$ \\
\hline 8. TÍTULO & Discurso pedagógico: efeitos de sentidos de criatividade \\
\hline AUTOR & $\begin{array}{l}\text { Regina Maria Varini Mutti (Professora do Departamento de Ensino e Currículo } \\
\text { da Faculdade de Educação e do Programa de Pós-Graduação em Educação da } \\
\text { Universidade Federal do Rio Grande do Sul) }\end{array}$ \\
\hline TIPO DE PRODUÇÃO & $\begin{array}{l}\text { Nota da autora: Este trabalho decorre do meu projeto de pesquisa intitulado: "A } \\
\text { criatividade no discurso pedagógico - O professor que ensina com o } \\
\text { computador", vinculado ao projeto interinstitucional integrado: "Programa } \\
\text { Comunidades Virtuais de Aprendizagem" (PROVIA/FACED/UFRGS/CNPq) }\end{array}$ \\
\hline ÁREA & Educação \\
\hline DATA & Acesso em 04.12.2010 \\
\hline $\begin{array}{l}\text { LOCAL DA } \\
\text { PUBLICACÃO }\end{array}$ & www.geocities.ws/gt_ad/reginamutti.doc \\
\hline RESUMO & $\begin{array}{l}\text { Em continuidade aos estudos sobre o discurso pedagógico, busco analisar } \\
\text { efeitos de sentidos vinculados ao sujeito-professor que usa a tecnologia } \\
\text { computacional em suas práticas curriculares no Ensino Fundamental e Médio, } \\
\text { concebida como de ruptura aos sentidos estabilizados. A criatividade é } \\
\text { relacionada ao modo singular como o professor se identifica à posição } \\
\text { discursiva pedagógica aliada à tecnologia, interrogando-a de modo a que faça } \\
\text { sentido para a sua prática, enquanto que, ao significá-la em sua enunciação, } \\
\text { configura os sentidos dessa posição discursiva que está se afirmando. O corpus } \\
\text { consiste em pronunciamentos de professores que atuam em escolas de Porto } \\
\text { Alegre sobre as suas práticas, através de entrevistas, gravadas e transcritas, } \\
\text { bem como de artigos que publicaram em revista educacional; inclui também a } \\
\text { manifestação de teóricos e pesquisadores sobre a tecnologia educacional, } \\
\text { através de palestra e entrevista, e ainda observações diversas, orais e escritas, } \\
\text { produzidas em situações institucionais que remetem à tecnologia nas práticas } \\
\text { curriculares. }\end{array}$ \\
\hline Nosso parecer & $\begin{array}{l}\text { Esse trabalho analisa dizeres de professores, portanto, analisa o discurso sobre } \\
\text { o discurso pedagógico. Contudo, os temas abordados, tecnologia educacional e } \\
\text { criatividade, não contemplam o discurso sobre o livro didático de inglês. Após a } \\
\text { leitura do artigo, concluo que ele é realmente um estudo sobre o discurso sobre } \\
\mathrm{X} \text {, apesar de que, focado na percepção de elementos que a levem a } \\
\text { compreender a relação do professor com sua prática no âmbito da tecnologia } \\
\text { educacional, a autora não se preocupa em definir, nem situar, seu próprio objeto } \\
\text { nem seu gesto interpretativo como analista do discurso sobre X. }\end{array}$ \\
\hline 9. TÍTULO & A celebração do Outro - arquivo, memória e identidade \\
\hline AUTOR & Maria José Coracini \\
\hline TIPO DE PRODUÇÃO & $\begin{array}{l}\text { Livro: Cap. 5: Discurso de e sobre a (in)submissão feminina } \\
\text { Cap. 10: Discurso sobre tradução: aspectos da configuração identitária do } \\
\text { tradutor }\end{array}$ \\
\hline ÁREA & Linguística aplicada \\
\hline DATA & 2007 \\
\hline $\begin{array}{l}\text { LOCAL DA } \\
\text { PUBLICAÇÃO }\end{array}$ & Campinas: Ed. Mercado de Letras \\
\hline RESUMO & Não há. \\
\hline Nosso parecer & $\begin{array}{l}\text { Tendo brevemente observado o conceito de discurso sobre no capítulo quatro, } \\
\text { ao citar a definição de discurso sobre de Bethania Mariani (O PCB e a } \\
\text { imprensa, 1999), a Professora Coracini não reelabora a noção de discurso } \\
\text { sobre e o utiliza, nos demais capítulos, sem distinção localizada (nas análises } \\
\text { dos dizeres ou em sua argumentação) entre discurso de e discurso sobre nos } \\
\text { demais capítulos do livro. Não há capítulos que tratem do livro didático. }\end{array}$ \\
\hline
\end{tabular}




\begin{tabular}{|c|c|}
\hline 10. TÍTULO & $\begin{array}{l}\text { Avaliação e seleção de livros / materiais didáticos para o ensino de línguas } \\
\text { - relato de uma oficina }\end{array}$ \\
\hline AUTOR & Renato Caixeta da Silva - CEFET - MG / PUC - Rio \\
\hline TIPO DE PRODUÇÃO & Artigo publicado nos anais do II SILID/I SIMAR \\
\hline ÁREA & Linguística \\
\hline DATA & 2008 \\
\hline $\begin{array}{l}\text { LOCAL DA } \\
\text { PUBLICAÇÃO }\end{array}$ & II SILID/ I SIMAR \\
\hline RESUMO & $\begin{array}{l}\text { A oficina relatada propôs e proporcionou uma reflexão de professores a respeito } \\
\text { da avaliação/ seleção de livros e materiais didáticos para ensino de línguas } \\
\text { através da discussão dos tópicos: público-alvo, objetivos, contexto, } \\
\text { conteúdo,recursos, metodologia, abordagem. São relatadas as atividades da } \\
\text { oficina e as informações obtidas através de um questionário que orientou a } \\
\text { discussão a partir dos dados advindos das realidades dos participantes. Por fim, } \\
\text { avalia-se positivamente a realização dessa atividade no evento II SILID / I } \\
\text { SIMAR. }\end{array}$ \\
\hline Nosso parecer & $\begin{array}{l}\text { O texto resultou das observações do pesquisador em uma oficina de avaliação } \\
\text { do LD de LM e LE por professores durante o II SILID. Os professores } \\
\text { participantes do evento preencheram um questionário para avaliar e selecionar } \\
\text { livros didáticos. Os dados obtidos através do questionário e a posterior } \\
\text { discussão foram usados para a reflexão sobre critérios de avaliação e escolha } \\
\text { do LD. Quanto à representação do LD, palavras chave foram obtidas das } \\
\text { respostas dos questionários, agrupadas, tabuladas, e usadas para a reflexão } \\
\text { sobre os critérios. Outros textos desse evento mencionam representações de } \\
\text { LD como sendo cristalizadas, tomando-as como naturalizadas e, por isso, não } \\
\text { as investigam. }\end{array}$ \\
\hline 11. TÍTULO & $\begin{array}{l}\text { Crenças sobre o uso do material didático no ensino de línguas } \\
\text { estrangeiras }\end{array}$ \\
\hline AUTOR & Emanuele Coimbra Padilha e Caroline Mitidieri Selvero \\
\hline TIPO DE PRODUÇÃO & Artigo publicado nos anais do II SILID/I SIMAR \\
\hline ÁREA & Linguística \\
\hline DATA & julho-agosto de 2013 \\
\hline $\begin{array}{l}\text { LOCAL DA } \\
\text { PUBLICAC̣ÃO }\end{array}$ & VI SILID/III SIMAR \\
\hline RESUMO & $\begin{array}{l}\text { Este trabalho tem por objetivo refletir sobre o uso do material didático no ensino } \\
\text { de línguas estrangeiras. Para isso, será realizado um levantamento das crenças } \\
\text { encontradas em três dissertações de mestrado em que apareceram crenças de } \\
\text { professores e alunos relacionadas ao material didático. Posteriormente, nos } \\
\text { resultados de pesquisa, serão apresentadas as crenças encontradas nas } \\
\text { dissertações e se discutirá as que são comuns a todas e as que se diferem, } \\
\text { bem como possíveis explicações para as afirmações dos informantes, } \\
\text { embasadas na bibliografia sobre material didático e crenças apresentadas nesta } \\
\text { pesquisa. }\end{array}$ \\
\hline Nosso parecer & $\begin{array}{l}\text { O trabalho faz um levantamento das representações sobre o livro didático de } \\
\text { língua estrangeira nos dizeres de professores e alunos, objetivando determinar } \\
\text { aproximações e distanciamentos entre as "crenças" encontradas. Além disso, o } \\
\text { trabalho deseja explicar esses dizeres dos professores e alunos de acordo com } \\
\text { o estabelecido pelo viés teórico adotado. Portanto, concluímos que não há } \\
\text { proximidade entre a pesquisa descrita aqui e a nossa pesquisa, que tem o } \\
\text { discurso sobre o LDI como objeto. }\end{array}$ \\
\hline 12. TÍTULO & $\begin{array}{l}\text { Representações de graduandos em Letras sobre o papel do livro didático } \\
\text { de francês }\end{array}$ \\
\hline AUTOR & Lino Dias Correia Neto e Josilene Pinheiro-Mariza \\
\hline TIPO DE PRODUÇÃO & Artigo publicado nos anais do II SILID/I SIMAR \\
\hline ÁREA & Linguística \\
\hline DATA & julho-agosto de 2013 \\
\hline $\begin{array}{l}\text { LOCAL DA } \\
\text { PUBLICAÇÃO }\end{array}$ & VI SILID/III SIMAR \\
\hline RESUMO & $\begin{array}{l}\text { Muitos estudos em Linguística Aplicada provocaram uma sensível ampliação do } \\
\text { paradigma de aprender-ensinar uma língua. Nessa conjuntura, o livro didático } \\
\text { de língua estrangeira suporta novas exigências teórico-metodológicas. Neste } \\
\text { estudo qualitativo-exploratório (GIL, 2008), fizemos o levantamento das } \\
\text { representações de graduandos em Letras-Francês a respeito do papel do livro } \\
\text { didático no processo de ensino-aprendizagem. Para analisar nossos dados, } \\
\text { obtidos via questionários semiestruturados, usamos os pressupostos da } \\
\text { competência comunicativa (HYMES, 1979; ALMEIDA FILHO, 1993) e as } \\
\text { sugestões dos PCN para o ensino de língua. Os resultados revelam zonas de }\end{array}$ \\
\hline
\end{tabular}




\begin{tabular}{|c|c|}
\hline & $\begin{array}{l}\text { predileções dos nossos informantes, sobretudo no que diz respeito aos } \\
\text { aspectos estruturais da língua. }\end{array}$ \\
\hline Nosso parecer & $\begin{array}{l}\text { Apesar de o trabalho ter o discurso sobre o livro didático de língua estrangeira } \\
\text { (francês) como objeto de estudo, o objetivo de perceber as "predileções" dos } \\
\text { informantes aponta à percepção de sujeito centrado e à transparência de } \\
\text { sentido, o que distancia esse trabalho do nosso. }\end{array}$ \\
\hline 13. TÍTULO & $\begin{array}{l}\text { A análise de livro didático como instrumento de reflexão acerca das } \\
\text { concepções de língua, linguagem, leitura e escrita e suas implicações nas } \\
\text { práticas de ensino }\end{array}$ \\
\hline AUTOR & Luiz Carlos Souza Bezerra \\
\hline TIPO DE PRODUÇÃO & Artigo publicado nos anais do II SILID/I SIMAR \\
\hline ÁREA & Linguística \\
\hline DATA & julho-agosto de 2013 \\
\hline $\begin{array}{l}\text { LOCAL DA } \\
\text { PUBLICAÇÃO }\end{array}$ & VI SILID/III SIMAR \\
\hline RESUMO & $\begin{array}{l}\text { Pretende-se, neste trabalho, analisar a produção de pareceres de análises de } \\
\text { livros didáticos por alunos de licenciatura em Letras, com o intuito de refletir } \\
\text { acerca das concepçóes teóricas de língua, linguagem, leitura e escrita e suas } \\
\text { implicações nas práticas de ensino. O material é constituído de relatos de } \\
\text { experiência com oficinas de análises de livros e de pareceres elaborados pelos } \\
\text { estudantes. As análises estão respaldadas em Marcuschi (2008); Rojo (2008, } \\
\text { 2011); Geraldi (1992). Os resultados evidenciam que a produção de pareceres } \\
\text { contribuiu para elucidar a relação teoria e prática, bem como para compreender } \\
\text { o uso deste artefato nas práticas de ensino. }\end{array}$ \\
\hline Nosso parecer & $\begin{array}{l}\text { O trabalho descrito acima trata do discurso sobre o livro didático e observa as } \\
\text { representações construídas nesse discurso. A distância em relação à nossa } \\
\text { pesquisa, portanto, se dá na metodologia para a leitura dos dados obtidos e na } \\
\text { implicação prática desses dados. Isto é, esse trabalho atribui à produção de } \\
\text { dizeres sobre o livro didático a capacidade de "elucidar" uma relação entre a } \\
\text { teoria e a prática de ensino e "elucidar", também, o modo como o livro didático } \\
\text { deve ser usado. Há, portanto, uma abordagem descritiva e prescritiva que nos } \\
\text { distancia. }\end{array}$ \\
\hline 14. TÍTULO & Representações de alunos e professores acerca do livro didático de inglês \\
\hline AUTOR & Renato Caixeta da Silva \\
\hline TIPO DE PRODUÇÃO & Artigo publicado nos anais do II SILID/I SIMAR \\
\hline ÁREA & Linguística \\
\hline DATA & julho-agosto de 2013 \\
\hline $\begin{array}{l}\text { LOCAL DA } \\
\text { PUBLICAÇÃO }\end{array}$ & VI SILID/III SIMAR \\
\hline RESUMO & $\begin{array}{l}\text { Esta comunicação aborda parte de uma pesquisa de doutorado sobre } \\
\text { representações sociais (MOSCOVICI, 2003) do livro didático de inglês através } \\
\text { de análise semântico-discursiva de base sistêmico-funcional (Martin \& Rose, } \\
2003 / \text { 2007). A pesquisa se justifica pela necessidade de compreensão da } \\
\text { importância deste material de ensino como gênero discursivo presente na } \\
\text { cultura educacional, e como objeto de representação, dada sua relevância } \\
\text { política, econômica, cultural e pedagógica. Os dados, advindos de entrevistas } \\
\text { com docentes e questionários com alunos, foram analisados com base na } \\
\text { proposta semântico-discursiva, o que levou à nomeação das representações: } \\
\text { fonte, agente, facilitador, guia, possibilidade, atração, mercadoria, dentre outras. } \\
\text { Este estudo ainda sugere que as representações regulam as práticas sociais } \\
\text { dos usuários de livros didáticos. }\end{array}$ \\
\hline Nosso parecer & $\begin{array}{l}\text { Ao analisar dizeres de professores e alunos, esse trabalho se assemelha ao } \\
\text { nosso. A distância se dá, no entanto, em relação à filiação teórica, } \\
\text { principalmente, à não observação do movimento na construção de } \\
\text { representações. Isto é, para a AD, as representações tanto constroem como são } \\
\text { construídas pelas práticas sociais (discursivas e não discursivas). Isso porque } \\
\text { as práticas sociais funcionam a partir de formações sociais que, por sua vez, } \\
\text { estabelecem formações ideológicas que estabelecem formações discursivas } \\
\text { (que estabelecem o que pode e deve ser dito). Assim, vemos que há um } \\
\text { movimento circular entre a construção de representações e práticas sociais, que } \\
\text { tanto regulam como são reguladas. }\end{array}$ \\
\hline 15. TÍTULO & $\begin{array}{l}\text { Análise do livro didático de língua estrangeira moderna no PNLD (2011): } \\
\text { reflexões necessárias }\end{array}$ \\
\hline AUTOR & Vera Lúcia Lopes Cristovão \\
\hline TIPO DE PRODUÇÃO & Artigo publicado nos anais do II SILID/I SIMAR \\
\hline ÁREA & Linguística \\
\hline
\end{tabular}




\begin{tabular}{|c|c|}
\hline DATA & julho-agosto de 2013 \\
\hline $\begin{array}{l}\text { LOCAL DA } \\
\text { PUBLICACÃO }\end{array}$ & VI SILID/III SIMAR \\
\hline RESUMO & $\begin{array}{l}\text { Este trabalho objetiva fazer uma reflexão acerca do instrumento de avaliação } \\
\text { composto de categorias e critérios de análise do livro didático de língua } \\
\text { estrangeira moderna no PNLD. Problematizo alguns critérios de análise do } \\
\text { PNLD/2011 sendo meu recorte centrado nas categorias: "Coerência e } \\
\text { adequação entre a abordagem teórico-metodológica assumida pela coleção e a } \\
\text { proposta didático-pedagógica e objetivos explicitados", "seleção de textos" e } \\
\text { "compreensão escrita", e em suas respectivas questões. Apresento um cenário } \\
\text { que contextualiza o objeto do estudo; abordo, então, a fundamentação teórica } \\
\text { que ancora minhas reflexões; e, finalmente, proponho uma releitura/expansão } \\
\text { dos critérios de análise, com a especificação de escritores. }\end{array}$ \\
\hline Nosso parecer & $\begin{array}{l}\text { Esse trabalho trata especificamente de um mesmo documento do discurso } \\
\text { oficial que analisamos; porém, como a autora define, trata-se de uma reflexão e } \\
\text { não exatamente de uma análise discursiva dos dizeres desse documento. }\end{array}$ \\
\hline 16. TÍTULO & $\begin{array}{l}\text { Discursos e investimentos de poder em materiais de educação, prevenção } \\
\text { e promoção de saúde voltados ao publico idoso }\end{array}$ \\
\hline AUTOR & Luciana Fernandes Paulino e Vera Helena Ferraz de Siqueira \\
\hline TIPO DE PRODUÇÃO & Artigo publicado nos anais do II SILID/I SIMAR \\
\hline ÁREA & Linguística \\
\hline DATA & julho-agosto de 2013 \\
\hline $\begin{array}{l}\text { LOCAL DA } \\
\text { PUBLICAÇÃO }\end{array}$ & VI SILID/III SIMAR \\
\hline RESUMO & $\begin{array}{l}\text { Nesta pesquisa, analisou-se discursos sobre velhice, educação e saúde em } \\
\text { materiais de educação, prevenção e promoção de saúde dirigidos ao público } \\
\text { idoso, com base nas noções foucaltianas de disciplinarização, biopoder e } \\
\text { governamentalidade. Percebeu-se a prevalência do discurso sobre o } \\
\text { "envelhecimento ativo e saudável", o investimento em normas e prescrições } \\
\text { comportamentais, segundo uma visão biomédica de saúde, predominando o } \\
\text { discurso do risco, com foco na dimensão individualista de responsabilização dos } \\
\text { sujeitos por seu estado de saúde. A diversidade dos modos de interação com } \\
\text { estes materiais e seus possíveis desdobramentos, igualmente múltiplos, foi } \\
\text { considerada neste estudo. }\end{array}$ \\
\hline Nosso parecer & $\begin{array}{l}\text { Esse estudo analisa o discurso do livro didático sobre determinados temas. } \\
\text { Portanto, não trata exatamente do discurso sobre o livro didático de inglês. } \\
\text { Mesmo que tenha sob foco o discurso sobre X, esse trabalho faz um } \\
\text { levantamento de recortes sobre os temas determinados e não analisa os dizeres } \\
\text { do discurso sobre X. }\end{array}$ \\
\hline \multicolumn{2}{|c|}{ OUTRAS FONTES PESQUISADAS SOBRE O DISCURSO SOBRE O LIVRO DIDÁTICO DE INGLÊS } \\
\hline 1. TÍTULO & $\begin{array}{l}\text { SILID/SIMAR: a leitura dos títulos das apresentações e a busca por palavras } \\
\text { como "representação" e "discurso sobre" não apontaram a similaridades com a } \\
\text { nossa pesquisa nas três primeiras versões desses eventos. }\end{array}$ \\
\hline \multirow[t]{3}{*}{ DATAS } & I SILID: 2 e 3 de agosto de 2007 \\
\hline & II SILID/ I SIMAR: 28, 29 e 30 de julho de 2008 \\
\hline & III SILID/II SIMAR: 28, 29 e 30 de julho de 2010 \\
\hline Local & PUC-Rio \\
\hline 2. TÍTULO & Projeto Memória de Leitura \\
\hline RESPONSÁVEL & Márcia Abreu e Marisa Lajolo - UNICAMP \\
\hline DESCRIÇÃO & $\begin{array}{l}\text { Memória de Leitura é um projeto acadêmico voltado para pesquisas sobre a } \\
\text { história da leitura e do livro no Brasil. Desenvolvido junto ao Instituto de Estudos } \\
\text { da Linguagem da Unicamp. Seu objetivo é disponibilizar bibliografia, dados e } \\
\text { fontes primárias para pesquisadores da área, bem como difundir o resultado das } \\
\text { pesquisas desenvolvidas por seus pesquisadores. }\end{array}$ \\
\hline LOCAL & http://www.unicamp.br/iel/memoria/ \\
\hline 3. TÍTULO & LIVRES \\
\hline RESPONSÁVEL & Circe Maria Fernandes Bittencourt - FEUSP \\
\hline TIPO DE PRODUÇÃO & $\begin{array}{l}\text { O Banco de Dados LIVRES disponibiliza pela Internet o acesso à produção das } \\
\text { diversas disciplinas escolares brasileiras desde o século XIX até os dias atuais } \\
\text { e, fornece referenciais e fontes, por intermédio da recuperação de obras e } \\
\text { coleta de documentos sobre a produção didática, legislação, programas } \\
\text { curriculares, catálogos de editoras, etc. A organização do Banco de Dados } \\
\text { LIVRES se insere no projeto temático "Educação e Memória: organização de } \\
\text { acervos de livros didáticos", financiado pela Fundação de Amparo à Pesquisa } \\
\text { do Estado de São Paulo (FAPESP), no Centro de Memória da Educação } \\
\text { Escolar, da Faculdade de Educação da Universidade de São Paulo (CME). A }\end{array}$ \\
\hline
\end{tabular}




\begin{tabular}{|l|l|}
\hline & organização do LIVRES caracteriza-se por ser alimentado e ampliado \\
& constantemente pelas pesquisas de uma equipe de especialistas da área, que \\
analisam o livro didático em suas diferentes vertentes: conteúdos das diversas \\
disciplinas, processo de produção e história das editoras, memória e usos dos \\
livros em salas de aula. Trata-se de um projeto de pesquisa que tem se \\
desenvolvido no CME com apoio da Biblioteca da FEUSP e convênios \\
internacionais, visando intercâmbios para estudos comparados e \\
acompanhamento das pesquisas em outras instituições. \\
\hline LOCAL & http://www2.fe.usp.br/estrutura/livres/index.htm. \\
\hline
\end{tabular}


ANEXO A - PORTARIA NORMATIVA N. 7

\title{
GABINETE DO MINISTRO
}

\author{
PORTARIA NORMATIVA № 7, DE 5 DE ABRIL DE 2007 \\ Dispõe sobre as normas de conduta no âmbito \\ da execução dos Programas do Livro.
}

\begin{abstract}
O MINISTRO DE ESTADO DA EDUCAÇÃO, no uso de suas atribuições legais conferidas pelo art. 87 da Constituição Federal, e considerando ser o acesso ao livro um direito constitucional do educando; considerando a importância da participação do professor e profissionais da educação no processo de escolha das obras no âmbito dos Programas do Livro; considerando que o processo de escolha deve ser realizado de forma transparente com vistas a assegurar ao aluno o acesso a um material didático de qualidade, que contribua para o seu pleno desenvolvimento e para o exercício da cidadania; considerando que, em função das diversidades sociais e culturais que caracterizam a sociedade brasileira, bem como do pluralismo de idéias e de concepções pedagógicas, a escolha dos livros deve ter como base o conhecimento da realidade do aluno e da proposta pedagógica que norteia o trabalho da escola; considerando a necessidade de aperfeiçoar a regulamentação das formas de divulgação dos livros e demais materiais pelos Titulares de Direitos Autorais, no âmbito dos Programas do Livro; considerando, ainda, o disposto no caput do artigo 37 da Constituição Federal e na Lei no 8.429, de 2 de junho de 1992, que versa sobre os atos de improbidade administrativa, resolve
\end{abstract}

Art. 1은 Instituir normas de conduta para o processo de execução dos Programas do Livro.

Art. 2ำ Participam da execução as seguintes instituições: Ministério da Educação - MEC, por intermédio da Secretaria de Educação Básica - SEB, Secretaria de Educação Especial - SEESP, e Secretaria de Educação Continuada, Alfabetização e Diversidade - SECAD; Fundo Nacional de Desenvolvimento da Educação - FNDE; Secretarias de Educação dos Estados, Municípios e Distrito Federal; Escolas e Titulares de Direitos Autorais.

Art. 3ำ A participação das instituições de que trata o artigo ํㅜ implica na observância das obrigações e proibições, de cada uma delas, conforme a seguir:

$\S 1^{\circ}$ Constituem-se obrigações do MEC e do FNDE:

I - divulgar a forma e o atendimento dos Programas do Livro por meio do site www.fnde.gov.br, ou do Diário Oficial da União, ou de correspondências específicas aos participantes dos programas, no que couber;

II - promover e apoiar ações voltadas para a formação docente com vistas à escolha e ao uso do livro nas Escolas;

III - garantir a isonomia do processo de execução, não disponibilizando informações que privilegiem um ou outro Titular de Direito Autoral;

IV - adotar as providências cabíveis no caso de as Secretarias de Educação e os Titulares de Direitos Autorais que infringirem as normas de conduta;

$\mathrm{V}$ - identificar claramente a propriedade do material do MEC/FNDE, na primeira capa dos guias de escolha e nos demais materiais oficiais distribuídos.

$\S 2^{\circ}$ Constituem-se obrigações dos Titulares de Direitos Autorais ou dos seus representantes, cujas obras inscritas forem selecionadas:

I - imprimir, na primeira capa dos livros utilizados na divulgação, ou na face frontal dos demais materiais de divulgação, o texto: "Material de divulgação da Editora [nome da editora]" em tamanho correspondente a $10 \%$ da área de impressão da respectiva capa ou face, podendo constar o código da coleção correspondente no mesmo espaço;

II - quando se tratar de exemplares de livros utilizados na divulgação, a matéria prima e acabamento (papel, cores, laminação de capa, etc.) deverão respeitar exata e fielmente as 
especificações técnicas do Edital, e, exclusivamente no caso do PNLD 2008, esses livros não poderão ter características superiores às especificações técnicas mínimas definidas no Edital; III - imprimir, na quarta capa dos livros utilizados na divulgação, o Hino Nacional e o número do ISBN, deixando em branco a segunda e a terceira capas desses livros.

$\S 3^{\circ}$ Constituem-se proibições aos Titulares de Direitos Autorais ou aos seus representantes, cujas obras inscritas forem selecionadas:

I - oferecer vantagens de qualquer espécie a pessoas ou instituições vinculadas ao processo de escolha, no âmbito dos Programas do Livro, a qualquer tempo, como contrapartida à escolha de livros ou materiais de sua titularidade;

II - distribuir presentes ou brindes a pessoas ou instituições vinculadas ao processo de escolha, no âmbito dos Programas do Livro, a qualquer título, após a publicação do resultado da avaliação ou a divulgação dos guias de escolha pelo MEC/FNDE, até o final do período de escolha pela internet e pelo formulário impresso;

III - produzir e distribuir catálogo, ou outro material, com características gráficas ou outras características que induzam os professores a acreditar que se trata de material oficial, produzido pelo MEC/FNDE;

IV - utilizar logomarcas oficiais, selos dos Programas do Livro, ou marcas e selos graficamente semelhantes, para efeito de propaganda, publicidade e divulgação, ou qualquer outro que induza ao entendimento de que se trata de material oficial do MEC/FNDE;

$\mathrm{V}$ - distribuir exemplares de livros utilizados na divulgação, com textos ou imagens que induzam ao entendimento de que os mesmo são indicados, preferencialmente, pelo Ministério da Educação para adoção nas Escolas, em detrimento de outros;

VI - utilizar, nas formas de divulgação, livros de conteúdo (imagens e textos) diferente dos livros inscritos e selecionados para os programas, bem como livros com especificações técnicas diferentes daquelas estabelecidas no Edital;

VII - utilizar a senha de escolha ou o formulário impresso de escolha enviados pelo FNDE às Escolas;

VIII - realizar pessoalmente a divulgação ou entrega de qualquer material de divulgação dos livros, diretamente nas Escolas, após a publicação do resultado da avaliação ou a divulgação dos guias de escolha pelo MEC/FNDE, até o final do período de escolha pela internet e pelo formulário impresso, sendo permitida, durante esse período, a divulgação pelo envio de livros, catálogos, folders e outros materiais, exclusivamente por remessa postal, definida como a entrega de materiais de forma impessoal, pelos Correios ou forma equivalente, sem a presença do Editor ou seu preposto ou outrem com vínculo funcional evidente com o Titular de Direito Autoral;

IX - realizar orientação pedagógica nas Escolas ou Secretarias de Educação, após a publicação do resultado da avaliação ou a divulgação dos guias de escolha pelo MEC/FNDE até o final do período de escolha pela internet e pelo formulário impresso;

$X$ - imprimir informação na quarta capa dos livros utilizados na divulgação além do Hino Nacional e do número do ISBN, e imprimir qualquer informação na segunda e terceira capas desses livros; $\mathrm{XI}$ - transcrever para os materiais de divulgação, total ou parcialmente, os conteúdos constantes dos guias ou catálogos de escolha dos livros;

XII - patrocinar com qualquer quantia, material de propaganda (brindes, blocos, canetas, guardanapos, etc.), ou qualquer outro benefício, os eventos relativos aos Programas do Livro realizados pelas Escolas ou Secretarias de Educação.

$\S 4^{\circ}$ Constituem-se obrigações das Secretarias de Educação dos Estados, Municípios e Distrito Federal:

I - recusar vantagens de qualquer espécie em razão da escolha das obras no âmbito dos Programas do Livro;

II - orientar as Escolas quanto ao processo de escolha e utilização dos livros;

III - impedir a participação dos Titulares de Direitos Autorais, autores, ou de seus representantes, nos eventos promovidos pelas Secretarias de Educação relativos à escolha de livros;

IV - garantir a isonomia do processo de execução, não disponibilizando informações que privilegiem um ou outro Titular de Direito Autoral; 
V - adotar as providencias cabíveis no caso das Escolas de suas respectivas redes que infringirem as normas de conduta;

VI - recusar vantagens de qualquer espécie dos Titulares de Direitos Autorais ou de seus representantes, a titulo de doação, como contrapartida da escolha realizada no âmbito dos Programas do Livro;

VII - não disponibilizar espaço público para a realização de eventos promovidos pelos Titulares de Direitos Autorais, autores ou seus representantes, relacionados aos Programas do Livro.

$\S 5^{\circ}$ Constituem-se obrigações das Escolas:

I - impedir o acesso, em suas dependências, de Titulares de Direitos Autorais ou de seus representantes com o objetivo de divulgar livros referentes aos Programas do Livro, após a publicação do resultado da avaliação ou a divulgação dos guias de escolha pelo MEC/FNDE até o final do período de escolha pela internet e pelo formulário impresso;

II - não disponibilizar espaço público para a realização de eventos promovidos pelos Titulares de Direitos Autorais, autores ou seus representantes, relacionados aos Programas do Livro;

III - impedir a participação dos Titulares de Direitos Autorais, autores, ou de seus representantes, nos eventos promovidos pela Escola relativos à escolha de livros;

IV - garantir a isonomia do processo de escolha, não disponibilizando informações que privilegiem um ou outro Titular de Direito Autoral;

V - não solicitar a reposição de livros recebidos, porventura danificados, diretamente aos Titulares de Direitos Autorais ou seus representantes;

$\mathrm{VI}$ - recusar vantagens de qualquer espécie, dos Titulares de Direitos Autorais, autores ou de seus representantes, a titulo de doação, como contrapartida da escolha de obras referentes aos Programas do Livro;

VII - impedir o acesso à senha de escolha ou ao formulário de escolha.

Art. 4응 $\mathrm{O}$ prazo de escolha das obras dos Programas do Livro, referidos no artigo 3ำ, quando for o caso, será divulgado, dentre outras formas, no site do FNDE.

Art. 5 Será instituída pelo Presidente do FNDE, por meio de Portaria, a Comissão Especial de Apuração de Conduta para analisar e apurar o descumprimento desta Norma, no caso do recebimento de denúncias.

$\S 11^{\circ}$ Após análise da denúncia, a Comissão referida no caput deste artigo fará, se for o caso, as devidas diligências, enviará Notificação aos denunciados solicitando razões e justificativas, e, após a devida conclusão dos trabalhos, produzirá Relatório indicando os fatos apurados e recomendações de encaminhamentos e penalidades cabíveis para decisão do Presidente do FNDE.

$\S$ 2응 O Presidente do FNDE, após julgamento e decisão, emitirá Notificação ao denunciado comunicando o resultado e, se for o caso, aplicando a respectiva penalidade, sendo permitido ao denunciado impetrar Recurso Administrativo dirigido ao Conselho Deliberativo do FNDE.

$\S$ 3ㅇ O Conselho Deliberativo do FNDE, após receber e julgar o Recurso Administrativo apresentado, emitirá, por intermédio do seu Presidente ou substituto, a devida Notificação de Decisão, acatando integral ou parcialmente, ou não acatando o Recurso Administrativo, e, se for o caso, aplicando definitivamente a penalidade.

$\S 4^{\circ} \mathrm{O}$ descumprimento das obrigações e proibições estabelecidas no art. $3^{\circ}$, §§ $2^{\circ}$ e $3^{\circ}$, devidamente analisado, garantido o direito de defesa prévia, acarretará ao denunciado:

I - advertência escrita, a ser aplicada pelo Presidente do FNDE, quando se tratar de infração leve, a juízo e por sugestão da Comissão Especial de Apuração de Conduta;

II - multa de $20 \%$ do valor total da aquisição da obra, apurado com base no valor negociado por ocasião do respectivo programa/ano, a ser aplicada pelo Presidente do FNDE, nos casos do descumprimento do artigo $3^{\circ}$, especialmente dos incisos I, II e III do $\S 2^{\circ}$, e dos incisos IV, V, VI, IX e X do § 3; 
III - multa de $10 \%$ do valor total do contrato, apurado com base no valor negociado por ocasião do respectivo programa/ano, a ser aplicada pelo Presidente do FNDE, no caso do descumprimento do artigo 3o, especialmente dos incisos I, II, III, VII, VIII, XI e XII do § 3;

IV - suspensão da participação do Titular de Direitos Autorais do processo de inscrição e avaliação de suas obras por ocasião Programa subseqüente (quando houver nova escolha), nos casos em que for confirmado o descumprimento dos itens I e II combinados, ou do item V do $\S$ $3^{\circ}$, do artigo $3^{\circ}$ desta norma, definitivamente julgado.

$\S 5^{\circ} \mathrm{A}$ reincidência, por três anos consecutivos, em infrações que levem à advertência de que trata o item I do $\S 4^{\circ}$ acarretará multa de $1 \%$ do valor total do contrato, apurado com base no valor negociado por ocasião do respectivo programa/ano, a ser aplicada pelo Presidente do FNDE.

$\S 6^{0}$ A suspensão referida no item IV do $\S 4^{\circ}$ somente poderá ser aplicada pelo Conselho Deliberativo do FNDE, após recomendação do Presidente do FNDE.

$\S 7^{\circ} \mathrm{O}$ descumprimento das obrigações estabelecidas no art. $3^{\circ}, \S \S 1^{\circ}$, $4^{\circ}$ e $5^{\circ}$, será tratado observando a legislação pertinente, regulatória daquelas instituições.

$\S 8^{\circ}$ As multas referidas nos itens III e IV do $\S 4^{\circ}$ e no $\S 5^{\circ}$ deste artigo, quando julgadas anteriormente à vigência do contrato com o Titular de Direito Autoral relativo ao programa/ano objeto de infração, serão aplicadas no ato da assinatura do respectivo contrato, como condição prévia à sua validação, podendo o infrator, caso não concorde com a pena, desistir da sua participação no certame.

§ 9o Além das medidas estabelecidas nesta Portaria, o FNDE deverá notificar os órgãos competentes, em caso de ocorrência de fato que tenha repercussão nas esferas civil e criminal.

Art. 6ํㅡㄹ Esta Portaria entra em vigor na data de sua publicação.

Art. $7^{\circ}$ Revogam-se as disposições em contrario, em especial a Portaria no 2.963 de 29 de agosto de 2005, publicada no DOU 167, de 30/08/2005 seção I, página 7, e a Portaria MEC № 806 , de $28 / 03 / 2006$.

\author{
FERNANDO HADDAD \\ Ministro de Estado da Educação
}


ANEXO B - PRIMEIRO QUESTIONÁRIO DE PESQUISA

Pesquisa sobre a adoção do livro didático para o ensino de inglês do 69 ao $9^{9}$ ano da Rede Pública Nome da Escola (opcional):

Data: J 2010 - Cidade: Estado:

Séries em que leciona a disciplina de inglês:

1) A partir de 2011, as escolas públicas adotarăo livros didáticos para o ensino de inglês para 0 Fundamental II, do $6^{2}$ ao $9^{2}$ ano. Qual é a sua opinião sobre essa medida?

2) Que tipo de material você utiliza atualmente? Há quanto tempo você utiliza esse material?

3) Como a utilização do livro didático afetaria seu dia a dia?

4) Em sua opinião, de que modo o livro didático poderá (ou não) contribuir para o ensino de inglês como língua estrangeira na escola pública? Quais são as vantagens e/ou desvantagens?

5) Você gostaria de fazer algum outro comentário sobre a adoção e/ou utilização do livro didático de inglês na escola pública?

(para quaisquer questões, use o verso ou páginas adicionais se necessário)

Muito obrigada! 


\section{ANEXO C - SEGUNDO QUESTIONÁRIO DE PESQUISA}

Pesquisa sobre a adoção do livro didático para o ensino de inglês do $6^{\circ}$ ao $9^{\circ}$ ano da Rede Pública Nome da Escola (opcional):

Data: ______ / 2013 - Cidade:

Estado:

Anos escolares em que leciona a disciplina de inglês:

1. O livro didático de inglês do PNLD 2011 foi adotado por sua escola?

( ) Sim. Adotamos o livro Keep in Mind.

( ) Sim. Adotamos o livro Links.

( ) Não adotamos. Motivo:

2. Caso tenha sido adotado, o livro didático de inglês que você está utilizando foi

( ) sua primeira opção. /I/ ( ) sua segunda opção.

( ) a primeira opção em consenso com os demais professores.

( ) a segunda opção em consenso com os demais professores.

( ) outra:

3. Caso você utilize alguma das coleções adotadas, você está satisfeito(a)? Explique os motivos.

4. Em sua opinião, de que modo o livro didático está (ou não) contribuindo para o ensino de inglês como língua estrangeira na escola pública? Quais são as vantagens e/ou desvantagens dessa adoção?

5. A adoção nacional do livro didático de inglês na escola pública teve início em 2011, com a distribuição desse material para os alunos do $6^{\circ}$ ao $9^{\circ}$ ano do E.F. Essa adoção está sendo estendida para os demais segmentos através do PNLD 2012 (E.M.), PNLD 2013 ( $1^{\circ}$ ao $5^{\circ}$ ano E.F.) e renovada pelo PNLD 2014 ( $6^{\circ}$ ao $9^{\circ}$ ano, novamente). Na sua opinião, quais os pontos que melhoraram e quais precisam ainda ser melhorados nesse processo de adoção?

(Não há limites para o tamanho das respostas. Por favor, utilize mais espaço se precisar) 


\section{ANEXO D - AMOSTRAGEM DE QUESTIONÁRIOS RESPONDIDOS}

\section{P1Q1:}

Pesquisa sobre a adoção do livro didático para o ensino de inglês do 6ㅇ ao 9ㅇ ano da Rede Pública

Nome da Escola: \&\& Prof - Cymira Pres dos Santos

Data: 27 / O 5/2010 - cidade: \&. Bernädo do Campo/SP

Séries em que leciona a disciplina de inglês: Quintas séries

1) A partir de 2011, as escolas públicas adotarão livros didáticos para o ensino de inglês para o Fundamental II, do 60 ao 9o ano. Qual é sua opinião sobre essa medida?

acho otima, pois munca se deu muta umportancic para o ensino do ingles a falta de recursos é real. smente un problema parao professer que necessita, constantemente, prourar material para suas aulas. 1 caderno do aluno gure usamos tem facilitado nnito nossa vida. Ë recente a distrubuicä). 0 inglés ficon 2) Que tipo de material você utiliza atualmente? Há quanto tempo você utiliza esse material? es queli do por Caderno do aluno distribuído pela secr de odu munto tempo, cacós; posters; jogos; vídesstextos. aldurn como tesctos, jogos ev'ders 'há muto Tempo

O Caderno do aluno utilizado hà 2 anos

3) Como a utilização do livro didático afetaria seu dia a dia?

faciltari o Trabuhhodesde que josentilnado - mesmo livro para todas as escolas, para faulvia tamberm a vida do aluno, quando necessla mu das de escolaveonse gur a companhar a reauén 'a dídáticada mesma série ondefestudar. Cus veres não palum os oque ensi'

nan pois cada projessor usa materal deferentevero outro.

4) Em sua opinião, de que modo o fivro didático poderá (ou não) contribuir para o ensino de inglês como língua estrangeira na escola pública? Quais são as vantagens e/ou desvantagens?

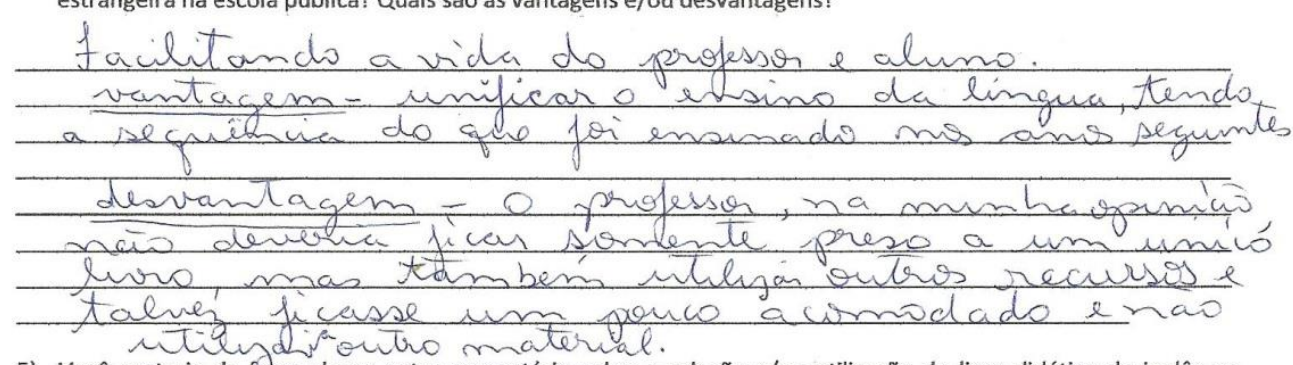

5) Você gostaria de fater algum outro comentário sobre a adoção e/ou utilização do livro didático de inglês na escola pública?

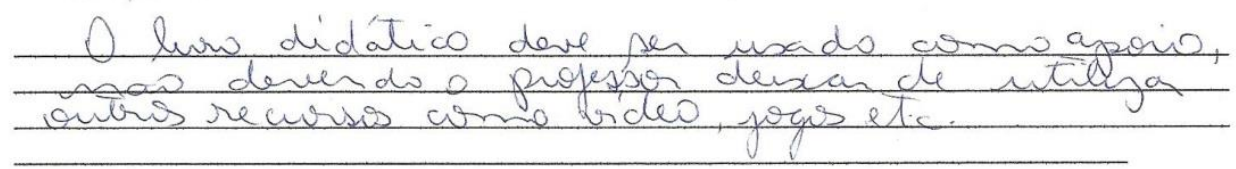


P2Q1:

Pesquisa sobre a adoção do livro didático para o ensino de inglês do 69 ao 9" ano da Rede Pública Nome da Escola: EE Prof: Cermira Pires dos Santos.

Data: $27 / 05 / 2010$ - cidade: Süo pervarde Campe /SP

Séries em que leciona a disciplina de inglês: $c^{\circ}, 70,8^{\circ}$ rérels, aro

1) A partir de 2011, as escolas públicas adotaräo livros didáticos para o ensino de inglès para o Fundamental II, do $6^{2}$ ao $9^{2}$ ano. Qual és sua opiniäo sobre essa medida?

mutto Bon. Olime panct es dicionárat sas materiaus de oppio e conosueta que pode
asedar bastante.

2) Que tipo de material vocé utiliza atualmente? Há quanto tempo você utiliza esse material?

Rivio, cadermo da Proposta curvicular de overeno

(ques si vem pronte) - com e conterido odequiodo a

cara sére, ans. Esse moterial é utilizado desde 2008 .

3) Como a utilizaçăo do livro dìdático afetaria seu dia a dia?

Meu dea a dia?" C näountende a quetä; mäo apetaria esm nada.

4) Em sua opiniăo, de que modo o livro didático poderá (ou nāo) contribuir para o ensino de inglês como lingua estrangeira na escola pública? Quais säo as vantagens e/ou desvantagens?

nä crie que nossa haver descantagens panques na minta eminto b livro didátice; desdl que lem sulecienade 2 com os centelido ategerados pan cada.

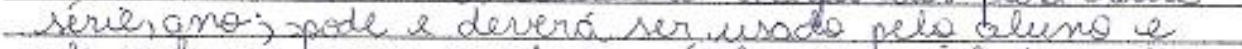
pele moleser como um bom e íctil material de opoco,

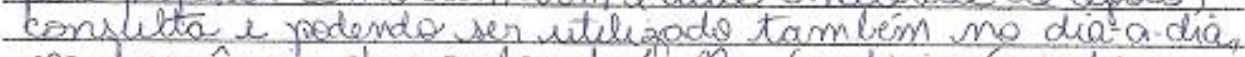

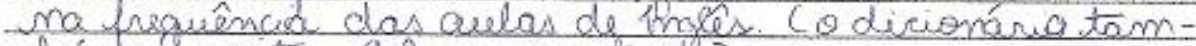
lém e muito wíte importante.

5) Voce gostaria de fazer alģum outro comentário sobre a adoçāo e/ou utilizaçăo do livro didático de ingläs na escola pública?

Qche importante discuterings em (junites) presseres de hales do buxine Fundamentel da essela dora escolhermos pentos o live mais adequado para

(para quaisquer questōes, use o verso se necessário)

Muito obrigada! 
P3Q1:

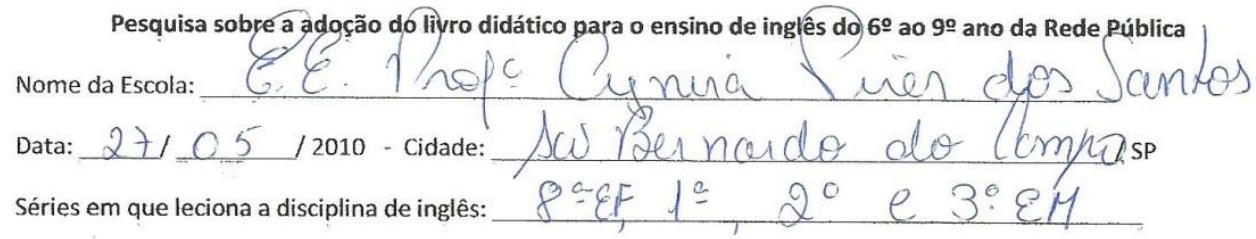

1) A partir de 2011, as escolas públicas adotarão livros didáticos para o ensino de inglês para o Fundamental II, do 60 ao 9o ano. Qual é sua opinião sobre essa medida?

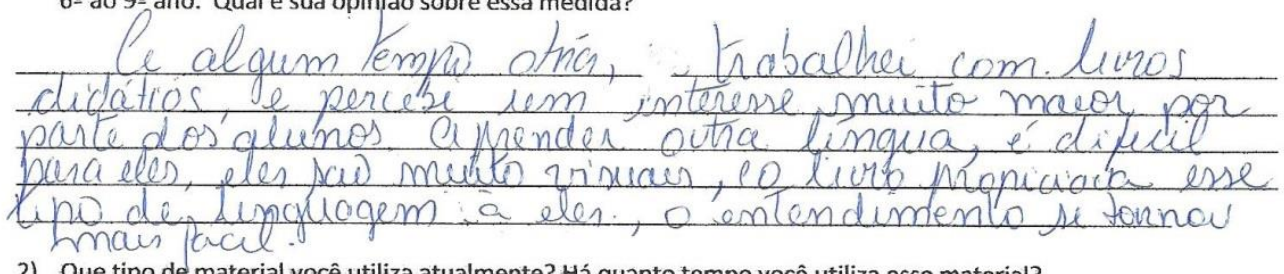

2) Que tipo de material você utiliza atualmente? Há quanto tempo você utiliza esse material?

\section{$\frac{\text { Atualmente, utulis as apostilad oferecichs pelo }}{\text { estado, en as iso desde que foram emplatadas. }}$}

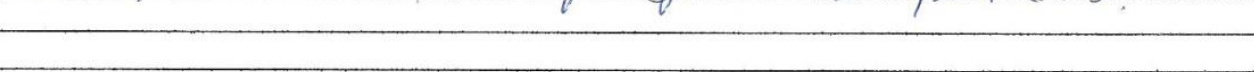

3) Como a utilização do livro didático afetaria seu dia a dia?

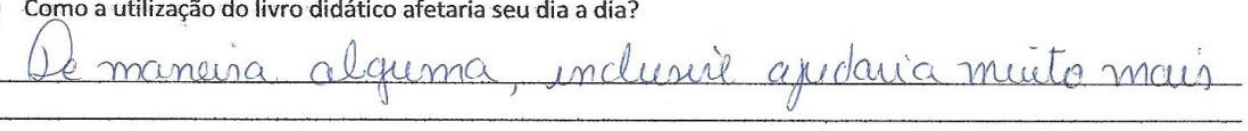

4) Em sua opinião, de que modo o livro didático poderá (ou não) contribuir para o ensino de inglês como língua estrangeira na escola pública? Quais são as vantagens e/ou desvantagens?

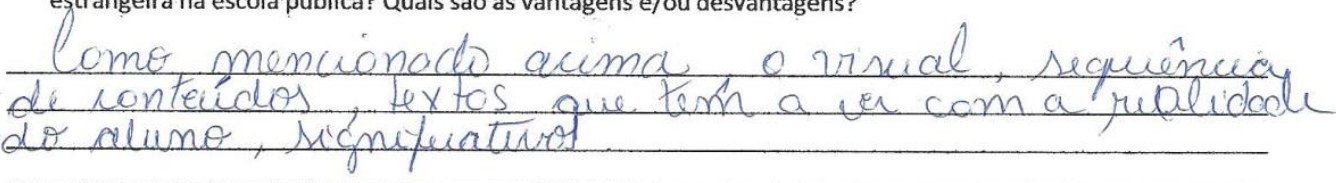

5) Você gostaria de fazer algum outro comentário sobre a adoção e/ou utilização do livro didático de inglês na

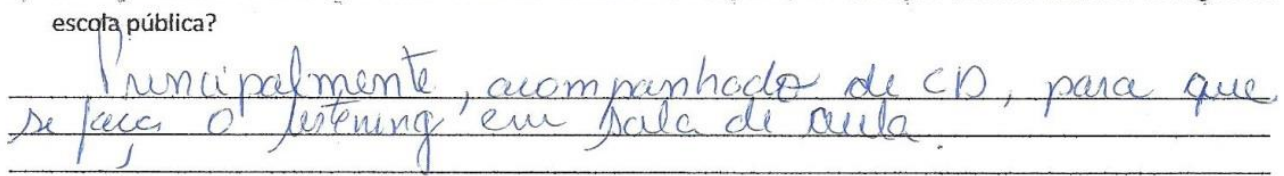


P4Q1:

Pesquisa sobre a adoção do livro didático para o ensino de inglês do $6^{\circ}$ ao $9^{\circ}$ ano da Rede Pública Nome da Escola (opcional):

Data: 24/ 11/ 2010 - Cidade: Campina Grande Estado: Paraíba

Séries em que leciona a disciplina de inglês: $6^{\circ}$ ao $9^{\circ}$ ano

1) A partir de 2011, as escolas públicas adotarão livros didáticos para o ensino de inglês para o Fundamental II, do $6^{\circ}$ ao $9^{\circ}$ ano. Qual é sua opinião sobre essa medida?

A adoção de livros didáticos para o ensino de Inglês está sendo uma conquista bastante significativa para os professores da área, pois estará previsto o desuso do velho discurso de que não se dá uma boa aula por falta de um suporte teórico.

2) Que tipo de material você utiliza atualmente? Há quanto tempo você utiliza esse material?

Devido à escola não disponibilizar nenhum material que eu pudesse utilizar nas aulas como suporte, eu me predispus a ter meu próprio acervo e comecei a comprar alguns livros e hoje possuo uma coleção completa e mais alguns livros adicionais. Eu os utilizo a cerca de três anos.

3) Como a utilização do livro didático afetaria seu dia a dia?

A utilização do livro didático facilitaria significativamente a minha prática de sala de aula, pois ele iria servir como um suporte no processo de ensino-aprendizagem da língua.

4) Em sua opinião, de que modo o livro didático poderá (ou não) contribuir para o ensino de inglês como língua estrangeira na escola pública? Quais são as vantagens e/ou desvantagens?

O livro didático e os seus variados enfoques e utilizações poderão ajudar expressivamente no uso das imagens, como uma ponte de auxílio para construir o significado do texto, no entanto, apenas o uso constante desse suporte pode torná-lo, assim como os demais à única ferramenta que o professor utilizará em sala de aula.

5) Você gostaria de fazer algum outro comentário sobre a adoção e/ou utilização do livro didático de inglês na escola pública?

Esse novo paradigma proporcionará para os professores da escola pública uma oportunidade para que eles possam refletir sobre a sua prática e assim dar um novo significado a ela.

Muito obrigada! 
P1Q2:

Pesquisa sobre a adoção do livro didático para o ensino de inglês

Nome da Escola (opcional): Esc. Est. Joō̃ alues Batista

Data: 17 O8/2012-cidade: Qroguainon Estado: To

Anos escolares em que leciona a disciplina de inglês: $6=17 \div 18: 19 \div-1 \div 12 \div 13=$ Ono. Midio

() Ensino Fundamental (X)Énsino Médio

1. O livro didático de inglês do PNLD 2011 foi adotado por sua escola?

(X) Sim. Adotamos o livro Keep in Mind.

( ) Sim. Adotamos o

( ) Sim. Adotamos o livro Links.

( ) Não adotamos. Motivo:

2. Caso tenha sido adotado, o livro didático de inglês que você está utilizando foi

( ) sua primeira opção. /// ( ) sua segunda opção.

( ) a primeira opção em consenso com os demais professores.

( ) a segunda opção em consenso com os demais professores.

( loutra: nato participei da escolha do livero.

3. Caso você utilize alguma das coleções adotadas, você está satisfeito(a)? Explique os motivos.

Sim, $\theta$ C. D room ajuda muito nas aulas. Q livero e. de fócil entendimento, Opropicio alumo consegre rescheer algumas atividodes.

4. Em sua opinião, de que modo o livro didático está (ou não) contribuindo para o ensino de inglês como língua estrangeira na escola pública? Quais são as vantagens e/ou desvantagens dessa adoção?

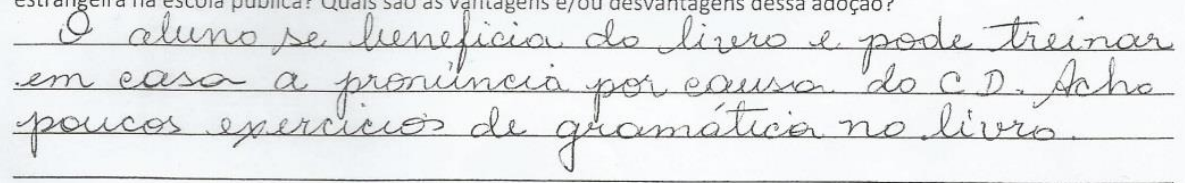

5. A adoção nacional do livro didático de inglês na escola pública teve início em 2011, com a distribuição desse material para os alunos do 6 a a 9 ㅇ ano do E.F. Essa adoção está sendo estendida para os demais segmentos através do PNLD 2012 (E.M.), PNLD 2013 (19 ao 5 ano E.F.) e renovada pelo PNLD 2014 (6 ao 9ㅇ ano, novamente). Na sua opinião, quais os pontos que melhoraram e quais precisam ainda ser melhorados nesse processo de adoção?

As aulas ficam mais dinòmicas, pois o prof: not̃

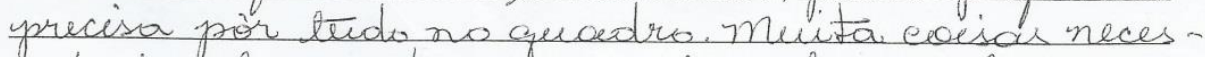
soirias de acerdo eom a serie está no liver mas

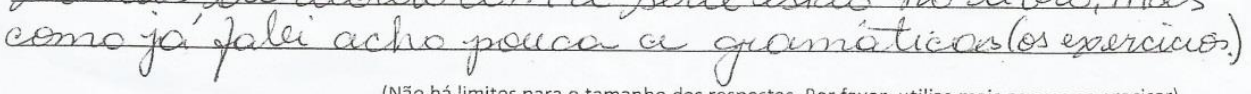

(Não há limites para o tamanho das respostas. Por favor, utilize mais espaço se precisar) 
P2Q2:

Pesquisa sobre a adoção do livro didático para o ensino de inglês do $6^{\circ}$ ao $9^{\circ}$ ano da Rede Pública Nome da Escola (opcional): COLÉGIO TIRADENTES DA POLÍCIA MILITAR DE MINAS GERAIS

Data: 25/ 01/ 2013 - Cidade: BELO HORIZONTE Estado: MINAS GERAIS

Anos escolares em que leciona a disciplina de inglês: $9^{\mathrm{a}}$. SERIE, $1^{\circ}$ ANO

1. O livro didático de inglês do PNLD 2011 foi adotado por sua escola?

) Sim. Adotamos o livro Keep in Mind.

( x ) Sim. Adotamos o livro Links.

) Não adotamos. Motivo:

2. Caso tenha sido adotado, o livro didático de inglês que você está utilizando foi

( $\mathrm{x}$ ) sua primeira opção. /// ( ) sua segunda opção.

( ) a primeira opção em consenso com os demais professores.

( ) a segunda opção em consenso com os demais professores.

( ) outra:

3. Caso você utilize alguma das coleções adotadas, você está satisfeito(a)? Explique os motivos.

_SIM, O LIVRO ATENDE ÁS PROPOSTAS ESTABELECIDAS PARA O USO DIDÁTICO COM

AMPLA ABORDAGEM DE VOCABULÁRIO E GRAMÁTICA ADEQUADOS À SÉRIE.

POSSUEM INÚMERAS IMAGENS E EXERCÍCIOS QUE FAVORECEM O VISUAL QUE TODOS ALUNOS E PROFESSORES PODEM USUFRUIR.

4. Em sua opinião, de que modo o livro didático está (ou não) contribuindo para o ensino de inglês como língua estrangeira na escola pública? Quais são as vantagens e/ou desvantagens dessa adoção?

ACREDITO QUE O LIVRO CONTRIBUI DE FORMA EFETIVA NA CONDUÇÃO DO ENSINO E APRENDIZAGEM DA LÍNGUA, COM A VANTAGEM DE PODERMOS CONCRETIZAR NOSSAS ASPIRAÇÕES QUE É A DE FOMENTAR O ENSINO DA LÍNGUA DE FORMA APRAZÍVEL. NOSSOS ALUNOS GOSTAM DO LIVRO, QUE É ACOMPANHADO DE UM CD PARA OUVIR EM CASA

5. A adoção nacional do livro didático de inglês na escola pública teve início em 2011, com a distribuição desse material para os alunos do $6^{\circ}$ ao $9^{\circ}$ ano do E.F. Essa adoção está sendo estendida para os demais segmentos através do PNLD 2012 (E.M.), PNLD 2013 ( $1^{\circ}$ ao $5^{\circ}$ ano E.F.) e renovada pelo PNLD 2014 ( $6^{\circ}$ ao $9^{\circ}$ ano, novamente). Na sua opinião, quais os pontos que melhoraram e quais precisam ainda ser melhorados nesse processo de adoção?

SE BEM DISTRIBUÍDO E NÃO HOUVER FALTA NAS ESCOLAS, O LIVRO IRÁ CONTRIBUIR PARA O MELHOR APERFEIÇOAMENTO DE TODOS OS ENVOLVIDOS NO PROCESSO DE ENSINO.

(Não há limites para o tamanho das respostas. Por favor, utilize mais espaço se precisar) Muito obrigada! Dolores (dolores@usp.br) 
P13Q2:

Pesquisa sobre a adoção do livro didático para o ensino de inglês do $6^{\circ}$ ao $9^{\circ}$ ano da Rede Pública Nome da Escola (opcional): EE D. Rosaria Isolina de Moraes

Data: 11_/ 01/ 2013 - Cidade: Itaquaquecetuba Estado: SP

Anos escolares em que leciona a disciplina de inglês: 13 anos

1. O livro didático de inglês do PNLD 2011 foi adotado por sua escola?

( $\mathrm{x}$ ) Sim. Adotamos o livro Keep in Mind.

( ) Sim. Adotamos o livro Links.

( ) Não adotamos. Motivo:

2. Caso tenha sido adotado, o livro didático de inglês que você está utilizando foi

(x) sua primeira opção. /// ( ) sua segunda opção.

(X ) a primeira opção em consenso com os demais professores.

( ) a segunda opção em consenso com os demais professores.

( ) outra:

3. Caso você utilize alguma das coleções adotadas, você está satisfeito(a)? Explique os motivos.

Digamos que estou satisfeita 40\%, não gosto muito da sequencia didática dos livros, misturam muitos assuntos que poderiam ser abordados de forma mais gradativa, principalmente para as series iniciais, sexto e sétimo ano.

4. Em sua opinião, de que modo o livro didático está (ou não) contribuindo para o ensino de inglês como língua estrangeira na escola pública? Quais são as vantagens e/ou desvantagens dessa adoção?

A contribuição visual é excelente, tendo em vista que não tínhamos material algum. Me fez economizar muito também, pois como antes não havia material colorido, com visual legal, nem ilustrações, eu investia muito em montagem de apostilas e xerox de atividades diferenciadas. Com o livro didático, essa parte fica mais fácil.

As vantagens são que os alunos podem fazer as atividades muitas vezes sozinhos, a partir do momento em que aprendem como fazer os exercícios. A desvantagem, como disse antes, é que a sequencia de assuntos abordados não ajuda muito a fixação de regras.

5. A adoção nacional do livro didático de inglês na escola pública teve início em 2011 , com a distribuição desse material para os alunos do $6^{\circ}$ ao $9^{\circ}$ ano do E.F. Essa adoção está sendo estendida para os demais segmentos através do PNLD 2012 (E.M.), PNLD 2013 ( $1^{\circ}$ ao $5^{\circ}$ ano E.F.) e renovada pelo PNLD 2014 ( $6^{\circ}$ ao $9^{\circ}$ ano, novamente). Na sua opinião, quais os pontos que melhoraram e quais precisam ainda ser melhorados nesse processo de adoção?

Pontos a ser melhorados: precisamos de mais opções de livros, e muitas vezes os livros escolhidos não são os que vêm para a unidade. Eu me considero sortuda, pois o livro que escolhi foi o que chegou, mas meus demais colegas de outras unidades escolares não receberam suas primeiras opções.

Poderiam disponibilizar mais jogos, assim como existem para a alfabetização.

(Não há limites para o tamanho das respostas. Por favor, utilize mais espaço se precisar)

Muito obrigada!

Dolores (dolores@usp.br) 
P14Q2:

Pesquisa sobre a adoção do livro didático para o ensino de inglês do $6^{\circ}$ ao $9^{\circ}$ ano da Rede Pública Nome da Escola (opcional): _E.M. Lidimanha Augusta Maia Data:_11_ _ 09 / 2012 - Cidade:__Brumadinho_ Estado:__MG Anos escolares em que leciona a disciplina de inglês: $\_6^{\circ}, 7^{\circ}, 8^{\circ}$ e $9^{\circ}$

1. O livro didático de inglês do PNLD 2011 foi adotado por sua escola?

( X ) Sim. Adotamos o livro Keep in Mind.

( ) Sim. Adotamos o livro Links.

( ) Não adotamos. Motivo:

2. Caso tenha sido adotado, o livro didático de inglês que você está utilizando foi

( ) sua primeira opção. /// ( ) sua segunda opção.

( $\mathrm{X}$ ) a primeira opção em consenso com os demais professores.

( ) a segunda opção em consenso com os demais professores.

( ) outra:

3. Caso você utilize alguma das coleções adotadas, você está satisfeito(a)? Explique os motivos.

Estou satisfeito porque percebo que os alunos estão mais interessados e se desenvolvendo mais com o uso do livro.

4. Em sua opinião, de que modo o livro didático está (ou não) contribuindo para o ensino de inglês como língua estrangeira na escola pública? Quais são as vantagens e/ou desvantagens dessa adoção?

Vejo só vantagens porque o livro foi desenvolvido por profissionais dedicados à produção de material didático. Antes do livro, eu produzia meu próprio material e, por mais que eu me esforçasse, ainda cometia alguns erros de palnejamento e/ ou produção. Além disso, o livro é único (ou duplo porque temos o Keep in Mind e ou Links), garantindo orientação uniforme para a produção de conhecimentos inerentes à língua inglesa no Brasil. Mais ainda: o livro didático vem com CD para contribuir sobremaneira na habilidade de "listening".

5. A adoção nacional do livro didático de inglês na escola pública teve início em 2011, com a distribuição desse material para os alunos do $6^{\circ}$ ao $9^{\circ}$ ano do E.F. Essa adoção está sendo estendida para os demais segmentos através do PNLD 2012 (E.M.), PNLD 2013 ( $1^{\circ}$ ao $5^{\circ}$ ano E.F.) e renovada pelo PNLD 2014 ( $6^{\circ}$ ao $9^{\circ}$ ano, novamente). Na sua opinião, quais os pontos que melhoraram e quais precisam ainda ser melhorados nesse processo de adoção?

Estou tão satisfeito com o livro didático, que ainda é difícil apontar uma deficiência nele. Porém, um ponto que penso que necessita melhora é na distribuição do livro didático, pois tenho alunos que não têm o livro e outros que só conseguiram o livro em 2012 graças a doações de outras escolas. Cabe esclarecer que alguns alunos devolveram seus livros velhos de 2011 e esses foram reutilizados em 2012, devido à falta de livro em Brumadinho. Cabe esclarecer também que, em Brumadinho, os estudantes do $6^{\circ}$ ao $9^{\circ}$ anos de escolas públicas municipais têm apenas uma aula semanal de inglês, o que impossibilita o esgotamento de um livro com apenas 40 aulas anuais. Logo, o livro previsto para o $6^{\circ}$ ano (que tem 16 unidades) é usado para o $6^{\circ}$ ano (unidades 1 a 4 ), para o $7^{\circ}$ ano (unidades 5 a 8), para o $8^{\circ}$ ano (unidades 9 a 12) e para o $9^{\circ}$ ano (unidades 13 a 16), caracterizando um aparente absurdo em minha opinião. Os livros previstos para o $7^{\circ}$ ano, $8^{\circ}$ ano e $9^{\circ}$ ano ficam na prateleira for falta de aplicação. Acredito que a solução seria prever essa lamentável realidade no processo de distribuição nacional ou o referido município aumentar a carga horária de língua inglesa, de forma a compatibilizála com o conteúdo pedagógico dos livros.

(Não há limites para o tamanho das respostas. Por favor, utilize mais espaço se precisar) Muito obrigada! Dolores (dolores@usp.br) 
ANEXO E - MATÉRIA VEICULADA PELO SITE DO CURSO UNIVERSITÁRIO

\section{Alunos terão livros de inglês e espanhol}

A partir de 2011, os alunos da rede pública dos anos finais do ensino fundamental (sexto ao nono ano) receberão livros didáticos de língua estrangeira (inglês e espanhol). A pré-inscrição das coleções e o cadastramento dos titulares de direito autoral junto ao Fundo Nacional de Desenvolvimento da Educação (FNDE), responsável pela compra das obras, vai de 12/01/09 a 27/03/09.

"É a primeira vez que vamos enviar livros de língua estrangeira para os alunos", lembra Sônia Schwartz, coordenadora geral dos programas do livro do FNDE, observando que já haviam sido distribuídos, anteriormente, livros de suporte para que os professores do ensino médio melhorassem o processo de aprendizagem em sala de aula. "Agora, distribuiremos para todos os estudantes dos anos finais do ensino fundamental e deveremos ampliar o atendimento para o ensino médio em 2012", afirma.

Pronúncia - Cada obra de língua estrangeira será acompanhada de um CD: "Ele é essencial para ensinar a pronúncia do inglês ou do espanhol", explica Sônia. Segundo ela, diversamente dos outros componentes curriculares, em que os livros devem ser utilizados por três anos consecutivos, os exemplares de língua estrangeira serão consumíveis: "O aluno vai poder escrever nele, já que será para seu uso exclusivo."

O edital do PNLD 2011 já está disponível no sítio eletrônico do FNDE. O prazo para a entrega das coleções, que abrangem livros de ciências, história, geografia, português e matemática, vai de 13 a 17/04/09. Depois disso, as obras serão avaliadas quanto às especificações técnicas e de conteúdo. Em 2010, virá a fase da escolha, em que diretores e professores selecionam os livros mais adaptados ao currículo da escola.

Amplitude - Atualmente, os programas do livro didático beneficiam 31 milhões de estudantes do ensino fundamental e 7 milhões do ensino médio. Em 2008, o FNDE adquiriu 103 milhões de exemplares para distribuí-los a alunos da rede pública de todo o país, com investimento de R $\$ 719$ milhões para a compra, sem contar o valor pago aos Correios para a distribuição. A entrega dos exemplares nas escolas começou em outubro de 2008 e deve terminar até o fim de janeiro de 2009.

Fonte: $\mathrm{MEC}$

Postado por: MA 19/12/08 
ANEXO F - MATÉRIA VEICULADA PELO SITE DO PORTAL CT

\section{Escolas estaduais entregam livros didáticos nesta sexta-feira em momento cívico}

11/02/11 10h08

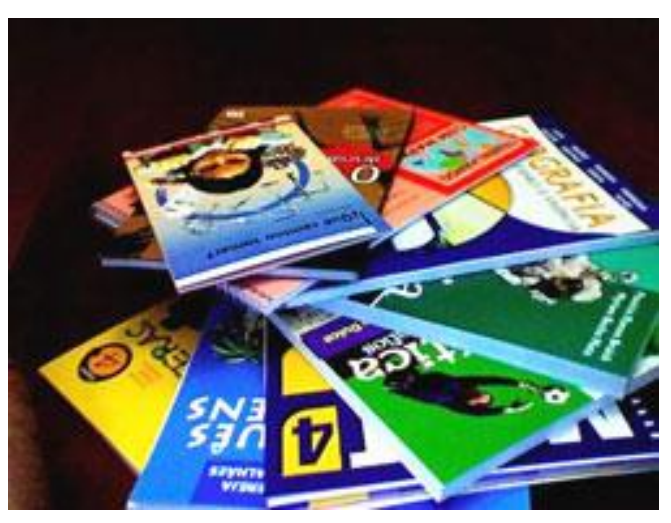

Correios vãso entregar 180 mil livros,

para os alunos do sexto ao novo ano
Os educadores da Escola Estadual Vila União fizeram na manhã desta sexta-feira, 11, a entrega dos livros didáticos, com momento cívico, apresentação de vídeo sobre 'o cuidado com o livro didático', realização de uma oficina sobre encapar livros e lançamento da ação 'melhor leitor do ano de 2011".

Na Escola Estadual São José, localizada na Quadra 1106 sul, em Palmas, serão realizadas duas palestras sobre a importância da leitura, uma às $14 \mathrm{~h} 30$, com o estudante de Pedagogia da UFT, Márcio Frota e outra com a psicóloga Vera Aparecida Benedito, às 16 horas.

Os livros didáticos são distribuídos pelo governo federal, por meio do Fundo Nacional de Desenvolvimento da Educação (FNDE) via Programa Nacional do Livro Didático (PNLD) e Programa Nacional do Livro Didático do Ensino Médio (PNLEM).

A distribuição dos livros está sendo realizada pelos Correios, diretamente às escolas urbanas. Os livros que irão para as escolas rurais serão entregues nas Secretarias Municipais de Educação de cada município.

Este ano, os Correios entregarão 180 mil livros, para os alunos do $6^{\circ}$ ao $9^{\circ}$ ano, das disciplinas de Língua Portuguesa, Ciências, Matemática, História e Geografia. Os alunos do $1^{\circ}$ e $2^{\circ}$ anos do ensino fundamental estarão recebendo livros de alfabetização em Língua Portuguesa e em Matemática. Os livros são utilizados por três anos consecutivos. As escolas estão recebendo exemplares para reposição dos livros do ensino médio e do $2^{\circ}$ ao $5^{\circ}$ ano do ensino fundamental.

A novidade este ano, é que os alunos do ensino fundamental vão receber livros de Língua Inglesa e Espanhol, são livros consumíveis, isto é, os exemplares ficarão para os alunos.

O secretário estadual da Educação, Danilo de Melo Souza, enviou para as escolas uma Instrução Normativa explicando sobre os livros didáticos que as escolas estão recebendo e falando da importância da conservação dos livros. A Secretaria da Educação ficará com uma reserva técnica de livros para fornecer no decorrer do ano, às escolas que necessitarem. (Da Assessoria de Comunicação) 
ANEXO G - CARTA CIRCULAR

ORIENTAÇOES PARA O REGISTRO DA ESCOLHA DO PNLD 2011 (6? ao $9^{2}$ ano)

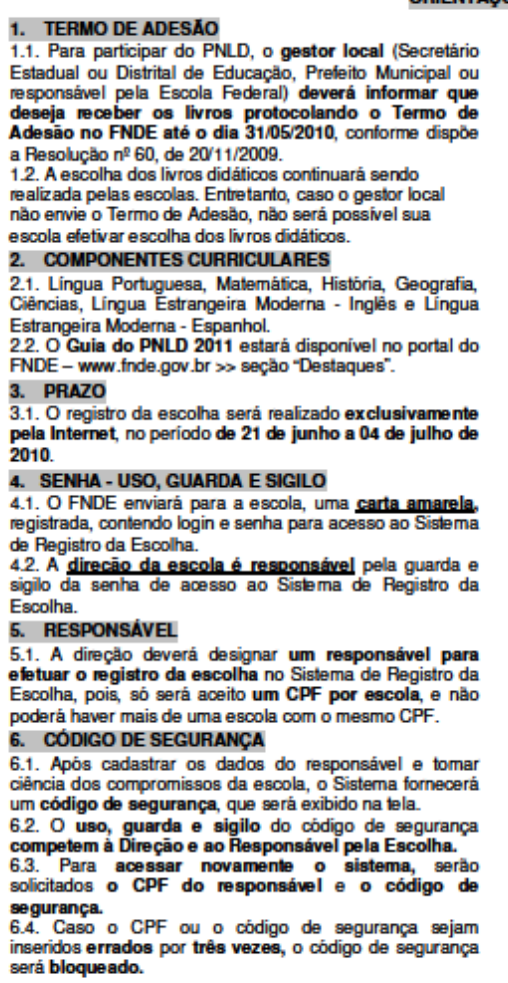
7. ESCOLHA

7.1. Será registrada pelo responsável, no Sistema de

Pegistro da Escolha no portal do FNDE www.fnde.gov.br näo for possivel fazer o registro da escolha em sua escola, procure outro local com acesso à Internet.

7.2. Para cada componente curricular, deverão ser

escolnidas duas opçoes (1 e 24), de editoras diferentes. Preenchida a y cpcáa, o responsavel so podera gravar

7.3. Caso năo se concretize a aquisiçăo com a editora da $1^{13}$ opcăo, serăo erviados os línros da $2^{4}$ opçào. Por esse motivo, a escolha da $2^{4}$ opçáo precisa ser tăo cuidadose quanto à da 1 .

7.4. Caso a escolla nào queira receber livros de algum componente curricular, ela deverá selecionar no registro de a opçăo "Nào desejo receber livros deste componente".

7.5. Se a escola nâ realizar o registro da escolha nem enclarar que nanhados, compulsoriamente, os titulos mais escolhidos do municipiolestado, desde que o gestor local Enha aderido ao PNLD por meio do Termo de Adesăo. 7.6. O registro da escolha realizada pela internet poderá
ser alterado a qualquer momento durante o periodo de ser alterado a quapu

registro da escolha. . portanto essa direçăo deve tormar as precauçoes para qu 8. ROUBO, FURTO, OU PERDA DE SENHA

8.1. Em caso de roubo ou furto, para receber nove senha, a direçao devera proceder como segue: própria escola ao FNDE juntamente Educaçấo ou de Ocorrência Policial referente ao roubo ou furto.

8.2. Caso o FNDE receba esses documentos até o dia 24 de junho de 2010, sera cancelados os registros da escolha constante no Sistema e outra senha será enviada por carta registrada

documentos depois do período acima mencionado, mas, ainda, durante o periodo de escolha, serăo cancolados os registros da escolla compulantariamente, os titulos mais escolhidos do municipiolestado, desde que o Gestor Local tenha aderido ao PNLD por meio do Termo de Adesăo.

8.4. Se esses documentos forem recebidos depois do periodo da escolha, os registros nâo poderăo ser mais

8.5. Caso de perda de carta amarela, registrada pela ECT 9. BLOQUEIO, PERDA E RECUPERAÇAO DO COODIGO DE SEGURANCCA

9.1. Em DEso de bloqueio 9.1. Em caso de bloqueio ou perda, o código pode ser recuperado, no próprio Sistema, pelo responsável. Ser 9.1.1. Acessar o Sistema, e, na segunda tela, clicar no link para recuperaçalo de oódigo. 9.1.2. Digitar no formulário apresentado, o CPF, RG e a data de nascimento do responsável.

9.1.3. Caso esses dados coincidam com os dados armazanados no Sistema, o Codgo de Segurança será

9.2. Após a terceira tentafiva com erro, o acesso será
desto bloqueado definitivamente, e prevalecerá o último registro da escoha gravado no Sistema. Os componentes curriculares que ficarem sem registro de escolha, a escola recebera, compulsoria

10. TRANSPARÉNCIA NO PROCESSO DE ESCOLHA 10.1. A direçăo da escola poderá descrever o processo de escolha, bem corno os títulos escolhidos, conforme modelo do Registro da heuna. de Escolha PNLD 2011, constarile no Guia PNLD 201

10.2. Recomendarnos também, que a direçắo da escola divulgue em suas dependências o comprovante de registro da reuniáo a que se refere o item 10.1, para controle da própria escola no processo de escolha e para ciência da comunidade escolar.

11. NORMAS DE CONDUTA NO AMBITO DA EXECUÇAO DOS PROGRAMAS DO UVRO 11.1. Devem ser observadas e respeitadas as normas

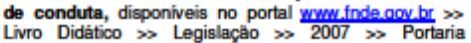
Livro Didático

DENUNCIE: 08006161 
ANEXO H - TEXTO INTEGRAL DO ITEM EM SALA DE AULA (KEEP IN MIND) GUIA DE LIVROS DIDÁTICOS - PNLD 2011

\section{KEEP IN MIND}

\section{COL33}

Elizabeth Young Chin

Maria Lúcia Fernandes Abreu Zaorob

Editora Scipione

\section{EM SALA DE AULA}

As propostas de produção escrita precisam ser orientadas no sentido de fornecer informações sobre os aspectos linguísticos a serem observados. Nos volumes 6 e 7, o professor deverá complementá-las com as etapas de produção e instruções para reformulação do texto produzido.

Em relação à compreensão oral, o aluno deve ser levado a observar a forma como os textos refletem as intenções, os objetivos comunicativos, os estados de ânimo e as atitudes dos interlocutores, bem como as consequências de variações dessa natureza para a comunicação. Um dos procedimentos que pode favorecer esse trabalho é o de pausar o CD para possibilitar reflexão, projeção, levantamento e checagem de hipótese.

Nas atividades de produção oral, convém que o professor oriente os alunos para conhecerem outras variedades da língua inglesa.

No trabalho com a gramática, é conveniente conduzir os alunos a um estudo mais reflexivo da língua.

Não foram encontrados erros significativos na obra. No entanto, na sua utilização em sala de aula, o professor precisará estar atento para corrigir algumas falhas de impressão e revisão no Livro do Aluno e no Manual do Professor. 


\section{LINKS - ENGLISH FOR TEENS}

24925 COL33

Amadeu Onofre da Cunha Coutinho Marques

Denise Machado dos Santos

Editora Ática

\section{EM SALA DE AULA}

Relativamente à compreensão escrita, as questões propostas não resgatam o contexto de produção dos textos, isto é, não são dadas ao aluno informações sobre o autor, o suporte (jornal, revista, etc.) e os locais de circulação do texto. A coleção não dá um tratamento específico ao texto literário. Por isso, o professor precisa completar as atividades de leitura com a exploração dos recursos expressivos que caracterizam o trabalho literário.

No que se refere à produção escrita, o professor deve prover atividades que, de fato, reflitam a diversidade de gêneros e tipos textuais, bem como a visão da escrita como um processo que inclui as etapas de pré e pós-escritura. Além disso, é aconselhável dedicar maior cuidado à revisão, à reescrita, à forma composicional dos gêneros textuais em estudo e à linguagem a ser usada nos textos (quanto ao vocabulário, ao emprego de recursos coesivos, ao grau de formalidade, por exemplo).

No trabalho com a compreensão oral, cabe ao professor a tarefa de levar o aluno a observar a forma como os textos refletem as intenções, os objetivos comunicativos, os estados de ânimo e as atitudes dos interlocutores, bem como as consequências de variações dessa natureza para a comunicação. Um procedimento que pode favorecer esse trabalho é o de pausar o CD para possibilitar reflexão, projeção, levantamento e checagem de hipótese.

Com referência à produção oral, deve-se proporcionar aos alunos oportunidades de se expressarem por meio de atividades menos controladas.

Convém dar ao trabalho com a gramática um caráter mais articulado com o uso da língua através das quatro habilidades. Com relação ao vocabulário, o aluno pode ser estimulado a utilizar estratégias de expansão e organização de seu conhecimento lexical.

Não foram encontrados erros significativos na obra. No entanto, na sua utilização em sala de aula, o professor precisará estar atento para corrigir algumas falhas de impressão e revisão no Livro do Aluno e no Manual do Professor. 